\title{
The Role of Financial Institutions in Corporate
}

\section{Governance of Listed Chinese Companies}

\author{
Rongli Yuan
}

A Thesis Submitted in Fulfilment

of the Requirements for the Degree of Doctor of Philosophy of Cardiff University

Cardiff Business School

Cardiff University

2005 
UMI Number: U583999

All rights reserved

INFORMATION TO ALL USERS

The quality of this reproduction is dependent upon the quality of the copy submitted.

In the unlikely event that the author did not send a complete manuscript and there are missing pages, these will be noted. Also, if material had to be removed, a note will indicate the deletion.

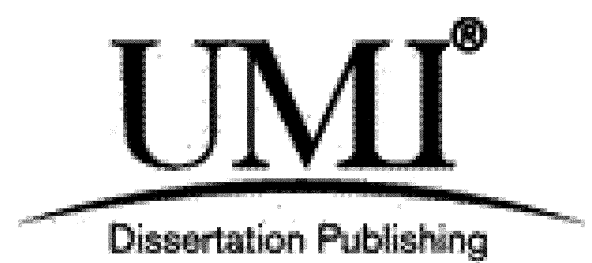

UMI U583999

Published by ProQuest LLC 2013. Copyright in the Dissertation held by the Author.

Microform Edition () ProQuest LLC.

All rights reserved. This work is protected against unauthorized copying under Title 17, United States Code.

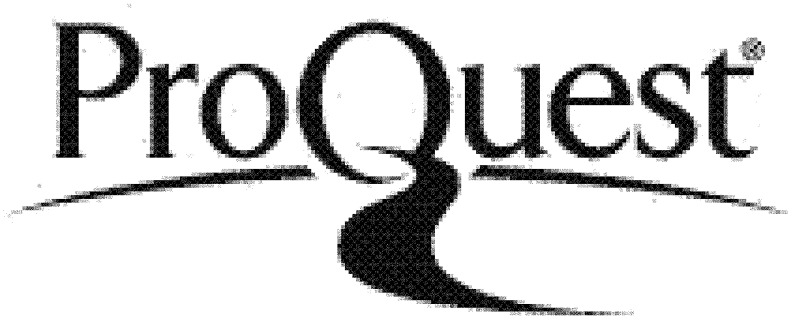

ProQuest LLC

789 East Eisenhower Parkway

P.O. Box 1346

Ann Arbor, MI 48106-1346 


\section{Declaration and Statement}

\section{Declaration}

This work has not previously been accepted in substance for any degree and is not being concurrently submitted in candidature for any degree.

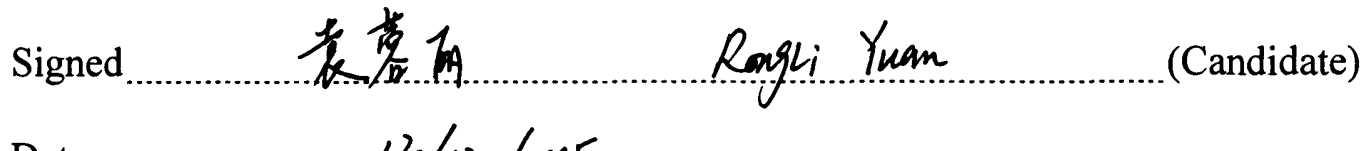

Date

$12 / 12 / 2005$

\section{Statement 1}

This thesis is the result of my own independent investigations, except where otherwise stated. Other sources are acknowledged by footnotes giving explicit references. A bibliography is appended.

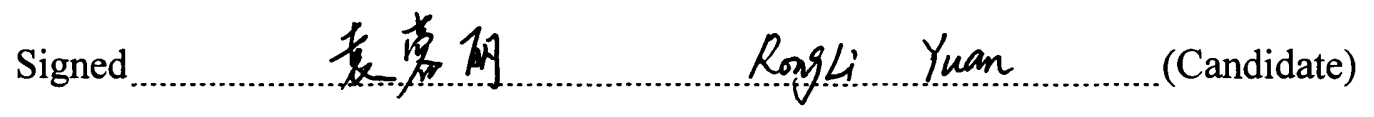

Date $12 / 12 / 2005$

\section{Statement 2}

I hereby give consent for my thesis, if accepted, to be available for photocopying and for inter-library loan, and for the title and summary to be available to outside organisations.

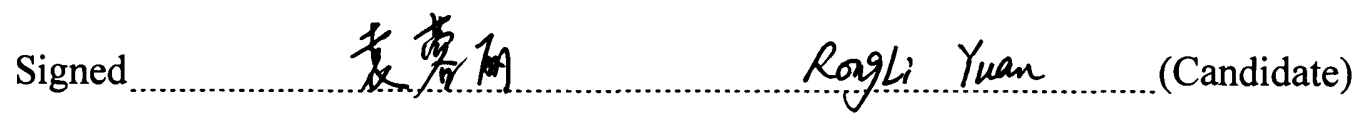

Date $12 / 12 / 2005$ 


\section{Acknowledgement}

First, and foremost, my deepest gratitude goes to my supervisor, Professor Jason Zezhong Xiao, who has provided me with financial support, invaluable guidance and encouragement throughout the duration of my study. His constructive suggestions, comments and sustained interest greatly assisted me at various stages of this study. My gratitude is also extended to my two other supervisors Professor Nikolaos Milonas and Dr. Hong Zou for their constant support and advice.

Special thanks go to Professor Zhihua Xie, Vice-President of Beijing Technology and Business University, who supplied me with useful information when I undertook interviews and a case study in China. My thanks are also due to Xiaodong Liao, the divisional director of Guodu Securities, for his professional support. I also thank all interviewees for providing their valuable responses and cooperation.

My appreciation is also extended to Prof. Laurence Copeland, Prof. Mahmoud Ezzamel, Prof. Gerald Makepeace from Cardiff Business School for their insightful comments and warm help. My thanks are also due to the secretarial staff of the $\mathrm{PhD}$ programme and the administrative staff of the Aberconway Library at Cardiff University for their generous help and assistance.

My thanks are due to Mei Yang, other friends and colleagues for their support, kindness and friendship throughout the entire period of my study.

Special thanks also go to my sisters, Rongrong Yuan, and Rongyan Yuan for their constant encouragement. Last, but not least, my very special thanks and great respect to my beloved Dad, Jizhao Yuan, Mum, Jiamei Hu, and husband, Dewu Zheng, who have always been a source of love and encouragement. This thesis is especially dedicated to the three of them. 


\begin{abstract}
This thesis explores the role of financial institutions in corporate governance of listed companies in China and their impact on firm performance, using both qualitative and quantitative methods.

The rise in institutional holdings and corresponding decline of the market for corporate control have focused academics and policy makers' attention on the role and importance of financial institutions as monitors of corporate management. Most prior studies of shareholder activism are based on the developed economies (e.g., the US and UK) and the results about the effect of this active monitoring are not conclusive. In China, the role of financial institutions has attracted little academic attention, partly because financial institutions are not perceived to play any significant role in corporate governance. Recently, however, there have been cases in which financial institutions have intervened into corporate strategic decisions. Thus, it is clearly important and urgent to assess the current role of financial institutions in corporate governance of listed companies in China.
\end{abstract}

The primary focus of this thesis centers on the role of Chinese financial institutions in corporate governance of listed companies. In particular, I address the following questions:

(1) What are the characteristics of firms that attract institutional investment?

(2) What are the expected and practical roles of financial institutions in corporate governance?

(3) What are factors that affect the role of Chinese financial institutions in corporate governance?

(4) What is the impact of institutional ownership on firm performance?

(5) How do financial institutions perform their role in practice?

To answer the first three questions, I interviewed both senior managers of financial institutions and board members of listed companies. The results indicate that most securities companies are passive investors, while a minority of active investment funds help the companies in which they invest to standardise their practices, improve their performance, and establish good images in the secondary securities market. This limited role can be attributed to a number of factors, including highly concentrated ownership structure, segmented share structure, premature regulatory environment, conflicts of interest, inadequate transparency and disclosure of financial information, and agency problems within financial institutions.

To answer the fourth question, I use a sample of 1,176 companies $(3,273$ observations) listed on the Shanghai and Shenzhen stock exchanges over a period from 2001 to 2003 to examine the relationship between institutional ownership and firm performance. I find that: (1) investment funds have a positive impact on firm performance and accounting performance influences their shareholdings; (2) the shareholdings of securities companies have no significant impact on firm performance. The results indicate that different financial institutions have differing impacts on firm performance.

To answer the fifth question, I focus on a specific case, in which fund managers took an unprecedented collective action to challenge a controversial proposal issued by China 
Merchants Bank (CMB). Though they ultimately achieved a very limited amount of success, the fund managers never gave up their efforts to fight for the rights of minority shareholders. Their unyielding action demonstrates that financial institutions' role in corporate governance is growing.

All in all, Chinese financial institutions (specifically investment funds) seem to have started to play a role in corporate governance and different financial institutions have differing performance effects on listed companies. The findings support the recent regulatory effort to promote financial institutions as a corporate governance mechanism with respect to investment funds, but suggest that further work is needed to enhance the role of securities companies as a monitoring device. The results also highlight that it is important to distinguish different types of financial institutions when examining their effects on firm performance in China.

This thesis has contributed to the ongoing study of this topic in the following aspects. First, I contribute to the extant literature about corporate governance in general, and the role of financial institutions in corporate governance in particular, by extending the research to China, which is a unique departure from existing work on the UK and US. Second, this thesis focuses on specific financial institutions, i.e., securities companies and investment funds, rather than legal person investors in general. Third, to my knowledge, this is the first study to employ both qualitative and quantitative methods to address the practice of financial institutions' involvement in corporate governance in listed Chinese companies. Fourth, it represents the first attempt to investigate the issues both from the point of view of the senior managers in financial institutions, on the one hand, and board directors of the companies they invest in, on the other hand. Fifth, this study is among the first to explore the governance role of financial institutions in listed Chinese companies from an agency perspective and finds that agency theory is useful in explaining the role of financial institutions in corporate governance and the agency problems of Chinese companies. But its application to China requires adequate considerations about the effect of contextual variables. In addition, it is also the first exploration of the recent phenomenon in China with a case study of how financial institutions attempted to influence corporate issues in a company in which they held shares, 


\section{Table of Contents}

Page

\section{Chapter One Introduction}

1.1 Introduction

1.2 Research background

1.3 Theory, research objectives and research questions 3

1.4 Research methodology $\quad 6$

1.5 Significance of this thesis 9

$\begin{array}{ll}\text { 1.6 Main findings and contributions } & 11\end{array}$

$\begin{array}{ll}1.7 \text { Structure and organisation of this thesis } & 14\end{array}$

\section{Chapter Two Agency Theory}

$\begin{array}{ll}2.1 \text { Introduction } & 16\end{array}$

$\begin{array}{ll}2.2 \text { An overview of agency theory } & 16\end{array}$

$\begin{array}{ll}2.3 \text { Agency problem } & 19\end{array}$

2.3.1 Traditional agency problem between managers and shareholders $\quad 19$

2.3.2 Expropriation of minority shareholders by controlling shareholders $\quad 20$

2.4 Agency theory and the role of financial institutions in corporate governance 22

2.4.1 Multiple agency contracts of financial institutions 22

2.4.2 The monitoring role of financial institutions in corporate governance 24

2.5 Problems of agency theory 26

2.5.1 About the model of man 26

2.5.2 About the efficient market 28

2.5.3 About other stakeholders $\quad 29$

2.5.4 About the uncertainty of outcome $\quad 29$

2.6 Agency theory and this thesis 32

$\begin{array}{ll}2.7 \text { Summary } & 35\end{array}$

\section{Chapter Three Literature Review Part I \\ Effectiveness of Corporate Governance Systems}

3.1 Introduction 37

$\begin{array}{ll}3.2 \text { An overview of corporate governance systems } & 38\end{array}$ 
3.2.1 Market-based system versus bank-based system 38

3.2.2 Weakness in the governance systems $\quad 42$

3.3 Corporate governance mechanisms: internal versus external 44

3.3.1 Internal mechanisms 45

3.3.2 External mechanisms $\quad 55$

3.4 Corporate governance in emerging economies $\quad 59$

$\begin{array}{ll}3.5 \text { Summary } & 63\end{array}$

\section{Chapter Four Literature Review Part II}

The Role of Financial Institutions in Corporate Governance outside China

4.1 Introduction $\quad 65$

4.2 Financial institutions around the world 66

4.2.1 Pension plans $\quad 66$

$\begin{array}{ll}\text { 4.2.2 Mutual funds } & 68\end{array}$

4.2.3 Insurance companies $\quad 68$

$\begin{array}{ll}4.2 .4 \text { Banks } & 69\end{array}$

4.3 An overview of the role of financial institutions in corporate governance $\quad 69$

4.3.1 Competing views about shareholder activism and its impact on targets $\quad 70$

4.3.2 The influence of legal environment $\quad 74$

4.4 Process of institutional participation in corporate governance $\quad 76$

4.4.1 The supply and demand of institutional participation in corporate $\quad 76$ governance

4.4.2 The extent of institutional participation in corporate governance $\quad 79$

4.4.3 Methods of institutional participation in corporate governance $\quad 80$

$\begin{array}{ll}\text { 4.5 Factors that affect the role of financial institutions in corporate governance } & 81\end{array}$

$\begin{array}{ll}\text { 4.5.1 The size of institutional shareholdings } & 81\end{array}$

4.5.2 Goal conflicts $\quad 82$

$\begin{array}{ll}\text { 4.5.3 Regulatory environment } & 83\end{array}$

4.5.4 Agency problems within financial institutions themselves 83

4.6 Institutional ownership and firm performance $\quad 84$

4.6.1 Performance-improved assumption $\quad 84$

$\begin{array}{lc}\text { 4.6.2 Performance-reduced assumption } & 85\end{array}$ 


\section{Chapter Five}

\section{General Background, Corporate Governance and Financial}

\section{Institutions in China}

5.1 Introduction $\quad 89$

5.2 The Chinese economy and economic reform 90

5.3 The development of Chinese stock market 90

5.4 State-owned enterprises and listed companies 96

5.4.1 The history of Chinese SOE reform 96

5.4.2 The listed company $\quad 98$

5.4.3 Agency problems in Chinese companies $\quad 99$

5.5 Corporate governance system in listed Chinese companies 102

5.5.1 The legal framework of corporate governance in China 102

5.5.2 The characteristics of corporate governance system 103

5.6 Internal corporate governance mechanisms 104

5.6.1 Ownership 104

5.6.2 Board of directors 105

5.6.3 Supervisory board 106

5.6.4 Independent directors 107

5.6.5 Managerial incentives 108

5.7 External corporate governance mechanisms 109

5.7.1 Market for corporate control 109

5.7.2 Managerial labour market 110

$\begin{array}{ll}\text { 5.7.3 Legal protection of investors } & 110\end{array}$

5.7.4 The role of the government/party 112

5.7.5 External auditing 113

$\begin{array}{ll}5.8 \text { Financial institutions in China } & 114\end{array}$

5.8.1 Commercial banks 114

5.8.2 Securities companies 117

$\begin{array}{ll}\text { 5.8.3 Securities investment funds } & 119\end{array}$

5.8.4 Trust and investment companies 121

5.8.5 Insurance companies 122 
$\begin{array}{ll}5.8 .7 \text { Underground funds } & 125\end{array}$

$\begin{array}{ll}\text { 5.8.8 The characteristics of financial institutions } & 126\end{array}$

5.9 The role of financial institutions in corporate governance in China 128

5.9.1 An overview of the role of financial institutions in corporate 128 governance

5.9.2 Empirical studies on institutional ownership 129

5.10 Summary

\section{Chapter Six Interview Evidence from China}

6.1 Introduction

6.2 Research questions

6.3 Research method and sample selection

6.4 Analysis and discussion of interview data

6.4.1 The characteristics of firms that attract institutional investment

6.4.2 The role of financial institutions in corporate governance

6.4.3 Factors that influence the role of financial institutions in corporate governance

6.5 Conclusion

\section{Chapter Seven}

\section{Institutional Shareholders and Corporate Governance: Empirical Evidence}

7.1 Introduction

$\begin{array}{ll}7.2 \text { Hypotheses development } & 158\end{array}$

$\begin{array}{ll}7.3 \text { Research design } & 161\end{array}$

$\begin{array}{ll}\text { 7.3.1 Data sources } & 161\end{array}$

$\begin{array}{ll}\text { 7.3.2 Sample selection } & 162\end{array}$

$\begin{array}{ll}\text { 7.3.3 Variables } & 163\end{array}$

$\begin{array}{ll}\text { 7.3.4 Regression models } & 168\end{array}$

$\begin{array}{ll}7.4 \text { Empirical analyses } & 169\end{array}$

$\begin{array}{ll}\text { 7.4.1 Descriptive statistics } & 169\end{array}$

$\begin{array}{ll}\text { 7.4.2 Correlation analysis } & 172\end{array}$ 
7.4.3 Multivariate results

7.5 Robustness checks

7.5.1 Endogeneity issues - a simultaneous-equation analysis

7.5.2 Estimation in changes

7.5.3 Other checks

\section{Chapter Eight}

\section{Shareholder Activism: The Case of China Merchants Bank}

8.1 Introduction

8.2 Research method and data sources

8.3 The background of China Merchants Bank 198

8.3.1 The ownership structure 198

8.3.2 The top ten shareholders 200

8.3.3 The top ten tradable shareholders 201

8.3.4 The corporate governance of China Merchants Bank 202

8.4 The dispute between China Merchants Bank and financial institutions 203

8.4.1 The incident that ignited the dispute 203

8.4.2 The process of the dispute 204

$\begin{array}{ll}8.5 \text { Discussion } & 210\end{array}$

8.5.1 The factors that affected the outcome of the dispute 210

8.5.2 The effectiveness of other corporate governance mechanisms 213

8.5.3 The nascent shareholder activism in China 217

8.5.4 The prospect of shareholder activism in China 224

$\begin{array}{ll}8.6 \text { Conclusion } & 227\end{array}$

\section{Chapter Nine Conclusion and Implications}

9.1 Introduction 229

9.2 Research questions and summary of findings 229

9.3 Empirical contributions 232

9.4 Theoretical contributions 233

9.4.1 The explanatory power of agency theory 233

9.4.2 Implications for academics 235 
9.5 Methodological contributions 236

9.6 Implications for policy makers and practitioners $\quad 237$

9.6.1 About the role of financial institutions in corporate governance 237

9.6.2 About the corporate governance of Chinese companies in general 239

9.7 Limitations 241

9.8 Avenues for future research $\quad 242$

\section{Appendices}

Appendix 1 Interview schedule of Chapter Six 243

Appendix 2 The effect of institutional ownership on firm performance on a 244 contemporaneous basis

Appendix 3 The impact of institutional ownership on ROE 247

Appendix 4 The impact of institutional ownership on MBR 249

Appendix 5 The impact of institutional ownership using dummy variable on firm 251 performance

Appendix 6 Interview schedule of Chapter $8 \quad 252$

$\begin{array}{ll}\text { Bibliography } & 253\end{array}$ 


\section{List of Tables}

Table Page

Table 5.1 Statistics of share turnover from 1998 to $2003 \quad 118$

$\begin{array}{ll}\text { Table 5.2 Investment restrictions in China at a glance } & 127\end{array}$

$\begin{array}{ll}\text { Table 6.1 Information about interviewees } & 137\end{array}$

Table 6.2 Information about participants from financial institutions 138

$\begin{array}{ll}\text { Table 7.1 Firm performance variables } & 170\end{array}$

$\begin{array}{ll}\text { Table } 7.2 \text { Ownership variables } & 171\end{array}$

$\begin{array}{ll}\text { Table 7.3 Other characteristics variables } & 172\end{array}$

$\begin{array}{ll}\text { Table 7.4 Correlations and collinearity diagnostics } & 174\end{array}$

Table 7.5 Fixed-Effects estimation of the effect of institutional ownership on 175

firm performance

Table 7.6 Pearson correlation coefficients of simultaneous equations 185

Table 7.7 Simultaneous equation analysis of institutional ownership and firm $\quad 186$ performance

Table 7.8 The effect of institutional ownership change on firm performance 191

Change

Table 8.1 The ownership structure of China Merchants Bank 199

Table 8.2 The top ten shareholders of China Merchants Bank 200

Table 8.3 The top ten tradable shareholders of China Merchants Bank 201 


\section{List of Figures}

Figure

Page

Figure 2.1 Application of agency theory to financial institutions 


\section{Chapter One}

\section{Introduction}

\subsection{Introduction}

This chapter presents research background, describes the theory, research objectives, and research questions, discusses research methodologies and significance of this thesis, provides main findings and contributions, and finally presents the structure and organisation of this thesis.

\subsection{Research background}

Corporate governance is a response to the agency problems that arise from the separation of ownership and control in a corporation (Boubakri et al., 2005), and encompasses a set of institutional and market mechanisms that induce self-interested managers to maximise the value of the residual cash flows of the firm on behalf of its shareholders. As the purpose of modern corporate governance is to increase shareholders and economic wealth in a sustainable way (Healy, 2003), great attention has been paid to corporate governance almost all over the world since the 1990s. Along with the increased attention on corporate governance, the role of institutional shareholders as monitors of corporate management is becoming of great importance (Smith, 1996; Choi and Cho, 2003).

With the increasing presence of financial institutions in financial markets (Gompers and Metrick, 2001), it is not surprising that they become an increasingly important control mechanism affecting corporate governance worldwide (Gillan and Starks, 2003).

In the United States, the proportion of shares owned by financial institutions has dramatically grown for the last 30 years, and now, about half of shares of the US corporations are owned by financial institutions. As institutional shareholdings in the US stock markets grow, some very large investors, usually public and private pension funds, began to emerge. Their sheer size enables them to own large enough shares in their portfolio companies to overcome the free-rider problem. It also makes it difficult for those 
institutions to apply the traditional so-called "Wall Street Rule." Since the management of those funds uses index funds that replicate the performance of some well-known market indices such as S\&P 500 as an important investment vehicle, and since the shareholdings of each funds in their portfolio companies are large, it is not easy to sell their shares in the market at the time and prices they want (Hawley and Williams, 2000). Due to these recent changes, some financial institutions began to play an active role in corporate governance. Companies with poor performance, or companies with some governance-related issues that are thought to be detrimental to shareholders' wealth, are usually selected as targets of shareholder activism of those financial institutions (Romano, 2001; Choi and Cho, 2003).

Within the general UK corporate governance debate, there is also an increasing emphasis on the need for institutional shareholders to play an active role in the governance of companies. It is estimated that financial institutions in the UK own between 65 and 80 per cent of the equity market (Ersoy-Bozcuk and Lasfer, 2001). The Cadbury Report (1992) notes that, 'because of their collective stake, we look to the institutions in particular, with the backing of the Institutional Shareholders' Committee, to use their influence as owners to ensure that the companies in which they have invested comply with the Code.' Part of the emphasis of the Cadbury Report on financial institutions as a means of improving corporate governance seemingly rests on the premises that they have the ability to influence the actions of companies because of their very size (Short and Keasey, 1997).

Shareholder activism ${ }^{2}$ has not been confined to the US and UK. There have been a number of shareholder rights groups in other countries as well, such as Australia, Korea, and Malaysia: For example, a group developed in Malaysia in August 2000 included institutional funds whose equity holdings accounted for 25 per cent of the Malaysian market capitalisation (Gillan and Starks, 2003).

Financial institutions thus have increasingly engaged in corporate governance activities, introducing proxy proposals and negotiating with management, with a goal of improving corporate performance (Romano, 2001). In addition to offering opportunities for minimising risks and increasing returns through professional selection of investment

\footnotetext{
${ }^{1}$ When a shareholder is dissatisfied with the company's performance, strategy, or governance, and he chooses to sell his share, he is said to follow the Wall Street Rule.

${ }^{2}$ Smith (1996) describes 'shareholder activism' as the increase in monitoring by traditionally passive financial institutions.
} 
vehicles, they aggregate the interest of many individuals and make their voice heard by representing them as shareholders of publicly traded companies (Belev, 2003).

In contrast, Chinese financial institutions are at a nascent stage of development (Gen, 2002). They are relatively few in numbers and small in scale. Further, because of their small market presence and limited power, they are only agents to make money for their principals, rather than owners of corporations (Zhang, 2002). Moreover, most financial institutions are born out of state-owned companies (Zhu et al., 2002) and do not establish an effective corporate governance system. As a result, many financial institutions suffer from the same problems as listed companies, including insufficient internal control, abuse of power, loose financial discipline and entanglement of the interests of controlling shareholders and those of the shareholders and investors (Cha, 2001). In addition, China has a restrictive system of investment options for financial institutions. Typically, different investor groups are subject to different investment restrictions.

Extant research conducted in the Chinese context concludes that Chinese financial institutions are passive investors and are not perceived to have played a monitoring role in corporate governance (Gen, 2002; Tam, 2002; Tenev et al., 2002; Zhang, 2002).

\subsection{Theory, research objectives and research questions}

Agency theory argues that in the modern corporation, in which ownership is separated from control, managerial actions depart from those required to maximise shareholder returns (Berle and Means, 1932; Pratt and Zeckhauser, 1985), so the agency problem derives from the conflicts between shareholders and managers (Jensen and Meckling, 1976). In an economy with controlling shareholders, another kind of agency problem derives from the conflicts between the outside shareholders and the controlling shareholders (Shleifer and Vishny, 1997). Agency theory also asserts that firms can employ various mechanisms to solve agency problems and align the interests of agents.

According to agency theory, institutional owners function as owners/principals to corporate management, and as 'agents monitoring other agents' (Varian, 1990) in their intermediary role monitoring corporate management for beneficial owners (Schneider, 2000). Many authors argue that the involvement of large shareholders in monitoring or control activities 
has the potential to limit agency problems. Empirical evidence on the monitoring role played by large shareholders has also provided support for this theory.

A model of institutional ownership should reflect both the primacy of ownership claims on the firm and the information asymmetries that may exist between principals and institutional owners (Schneider, 2000). Agency theory is important in developing such a model, as the former consideration is recognised in agency theory's general application to ownership, and the latter in application of agency theory to professional contracts (Sharma, 1997). Furthermore, agency problems associated with the separation of ownership and control are central to transition economies (Judge et al., 2003). Indeed, recent research suggests that there is not only a principal-agent problem in transition economies, but also principal-principal (e.g., majority-minority shareholder) problems (Young et al., 2002).

Thus, agency theory seems to be able to provide a more conducive basis for analysing the role of financial institutions in corporate governance in China compared with stewardship theory and stakeholder theory.

Based on agency theory and on the extant literature, this thesis attempts to explore the role of financial institutions in corporate governance of listed Chinese companies and its impact on firm performance. In particular, the following five research questions are addressed, gaining multiple sources of evidence within the same study.

First, what are the characteristics of firms that attract institutional investment? Financial institutions' participation in corporate governance of listed companies starts when they perform quality research about companies before investment to identify investment opportunities, so it is necessary to identify the characteristics of firms that attract institutional investment.

Second, what are the expected and practical roles of financial institutions in corporate governance? As a mix of financial, legal, and social influence has shaped financial institution activism and affected different financial institutions to different degrees, there must be a difference between the expected and practical roles of financial institutions in corporate governance of listed companies. 
Third, what are the factors that affect the role of Chinese financial institutions in corporate governance? One cannot take it for granted that if financial institutions have the incentive to intervene in firms, they will be able to successfully do so. It is quite possible that various structural and regulatory barriers prevent institutions from fully exercising their power on monitoring or motivate them to exercise it in a different direction.

Fourth, what is the impact of institutional ownership on firm performance? If financial institutions have the incentive and ability to monitor corporate management, this governance role should ultimately be manifested in improved firm performance. The impact of institutional ownership on firm performance can quantitatively explain the practical role of financial institutions in corporate governance.

Finally, how do financial institutions perform their role in practice? By means of analysing incentives and methods of financial institutions when they intervene in corporate issues of a company in which they invest, the role of financial institutions is further explored in a reallife context. In addition, this case study examines the interactions between financial institutions and other corporate governance mechanisms and highlights the problems in corporate governance and effectiveness of other corporate governance mechanisms.

The above research questions are related to two agency problems: one is the traditional agency problem between managers and shareholders, and the other is the expropriation of minority shareholders by controlling shareholders. This thesis addresses these questions in the following chapters.

Most literature use the phrase "institutional investors," while Holland (1995, 1998, and 1999), Holland and Doran (1998) use "financial institutions" to explore their role in corporate governance in the UK. What "institutional investors" and "financial institutions" refer to are the same groups of investors in developed economies, ${ }^{3}$ they are companies with multiple owners, who are interested primarily in portfolio investments, and that derive revenue from dividend income and/or realised capital gains from asset sales (Belev, 2003). In contrast, in China, institutional investors are different from financial institutions, as

\footnotetext{
${ }^{3}$ In the US, main financial institutions include pension funds, mutual funds, insurance companies, and bank trust (Schneider, 2000). Large UK financial institutions include life insurance, pension funds, unit trust and investment trust (Holland, 1999). In Japan, financial institutions include commercial banks, insurance companies, pension funds, mutual funds, investment trust, securities companies, and special interests (Chowdhury and Geringer, 2001).
} 
institutional investors are legal person investors, which include a minority of financial institutions such as mutual funds and pension pools, and a majority of other companies such as corporatised SOEs, shareholding firms, and private firms (Peng, 2004; Wang et al., 2004). Accordingly, legal person ownership (referred to as "overall institutional ownership") in recent empirical studies undertaken in the Chinese context includes both financial institutional shareholdings and non financial institutional shareholdings. In this thesis, the focus is only on Chinese financial institutions, as they are similar to their counterparts in developed economies (Gen, 2002) and expected to play a potentially significant role in improving corporate governance and stabilising the stock market (the China Securities Regulatory Commission, 2004). The phrase "financial institutions" is used in this thesis and "institutional ownership" is the ownership only held by Chinese financial institutions.

This thesis focuses on investment funds and securities companies for two reasons. First, because of legal restrictions, ${ }^{4}$ banks do not play any significant role in corporate governance of listed companies as they are forbidden to directly and actively hold company shares. ${ }^{5}$ Second, insurance companies are not allowed to invest in the stock market either until very recently; however, there is a strict investment-quota control over the amount of insurance funds can be invested in stock. Therefore, they are unlikely to play any significant role in corporate governance in China.

\subsection{Research methodology}

This thesis explores the role of financial institutions in corporate governance of listed companies in China combing qualitative and quantitative methods.

Qualitative methods facilitate study of issues in depth and detail. Approaching fieldwork without being constrained by predetermined categories of analysis contributes to the depth, openness, and detail of qualitative inquiry. This increases the depth of understanding of the cases and situation studies but reduces generalisability (Patten, 2002). Qualitative research is criticised for being too impressionistic and subjective, difficult to replicate, difficult to generalise, and lack of transparency.

\footnotetext{
${ }^{4}$ As discussed in Chapter 5, the Commercial Bank Law (1995, Article 43) in China forbids commercial banks to directly hold shares of listed companies

${ }^{5}$ However, banks may occasionally and passively become shareholders of listed companies when such shareholdings are used collaterals of bank loan and the borrowing firm cannot meet its liabilities.
} 
Quantitative methods, on the other hand, require the use of standardised measures so that the varying perspectives and experiences of people can be fit into a limited number of predetermined response categories to which numbers are assigned. The advantage of a quantitative approach is that it is possible to measure the reactions of a great many people to a limited set of questions, thus facilitating comparison and statistical aggregation of the data. This gives a broad, generalisable set of findings presented succinctly and parsimoniously. However, quantitative research is criticised for its failure to distinguish people and social institutions form 'the world of nature,' an artificial and spurious sense of precision and accuracy in the measurement process etc (Bryman, 2004).

Thus the difference between the two research methods might be summarised by saying that quantitative research is structured, logical, measured, and wide, while qualitative research is more intuitive, subjective, and deep (Bouma and Atkinson, 1997).

Because qualitative and quantitative methods involve differing strengths and weakness, they constitute alternative, but not mutually exclusive, strategies for research. Both qualitative and quantitative data can be collected in the same study (Patten, 2002). Quantitative research may be employed to plug the gaps in a qualitative study that arise because the researcher cannot be in more than one place at any one time. Alternatively, it may be that not all issues are amenable solely to a quantitative investigation or solely to a qualitative one (Bryman, 1994).

Burgess (1982) chooses the term 'multiple research strategies' to describe the use of diverse methods in tackling a research problem. The older and more widely used terminology that refers to this strategy is 'methodological triangulation' (see, Morgan, 1998). Methodological triangulation is an attempt to improve validity by covering many different research designs within the same study, as each source of evidence may be 'tested' against each other source of evidence (David, 2004). According to Burgess (1982), researchers ought to be flexible and therefore to select a range of methods that are appropriate to the research problem under investigation. Webb et al. (1966) argue that confidence in the findings deriving from a study using a quantitative research strategy can be enhanced by using more than one way of measuring a concept. Bird (1992) suggests that research can be more fruitful when both major research methods - the quantitative and the qualitative - are utilised. Thus, methodological triangulation can be used as a strategy for 
gaining multiple perspectives on complex phenomena (Handy, 1997). Hughes et al. (1997) and Deacon et al. (1998) provide examples of unplanned triangulation in that they gather data through several quantitative and qualitative research methods.

I combine both qualitative and quantitative methods to gain several sources of evidence on the role of financial institutions in corporate governance in listed Chinese companies. The results of qualitative investigation might be checked against the quantitative study, and enhance the validity of findings; meanwhile, quantitative and qualitative research methods are combined to provide a more comprehensive picture of financial institutions' role in corporate governance of listed companies.

In more detail, to answer the first three questions above, I interview both senior managers of financial institutions and board directors of listed companies. From their perspectives, I am able to provide balanced or more complete evidence on active institutional involvement in relation to corporate governance in China. Interviews help to provide background information on the role of financial institutions, act as a source of hypotheses, and help explain the factors underlying the relationships that are established. The interviews provide evidence that investment funds have started to play a role in corporate governance while most securities companies are passive investors.

To answer the fourth question, I use a sample of 1,176 companies (3,273 observations) listed on the Shanghai and Shenzhen stock exchanges over the period 2001-2003 to examine the relationship between institutional ownership and firm performance. The secondary data analysis relates the governance role of financial institutions to their performance effects, and gives a broad and generalisable set of findings. Meanwhile, it helps with the choice of people and subjects for the interviews and the case study. The results indicate that investment funds' shareholdings have a positive impact on firm performance while securities companies have no such impact.

To answer the fifth question, I focus on a specific case of how fund managers attempted to intervene in the corporate strategic decision. Such a case study is important as it illustrates the quantitative findings, thus enhancing the understanding of the governance role of financial institutions in a real-life context. This case study also implies that investment 
funds have begun to play a positive role in corporate governance while most securities companies are still passive shareholders.

In summary, combining the interviews, the secondary data analysis, and the case study, I obtain broadly consistent results and provide a real and comprehensive picture of the corporate governance role of financial institutions in listed Chinese companies.

\subsection{Significance of this thesis}

Theoretical argument (e.g., Admati et al., 1992) and empirical evidence (e.g., Smith, 1996) support that large institutional shareholders may have the incentive to expend resources on monitoring corporate management and promoting better corporate governance. This thesis contributes to the understanding of the role of financial institutions in corporate governance in China, a topic not hitherto examined previously. China is the largest emerging economy in the world with a rapidly expanding corporate sector and stock market. More importantly, China's corporate sector and stock market are increasingly integrated with the global economy through large amounts of foreign direct investment in China, China's accession to the World Trade Organisation (WTO), the introduction of qualified foreign institutional investor (QFII) system, ${ }^{6}$ and the increasing number of Chinese firms (including financial institutions) seeking listing status overseas. As a result, the Chinese corporate sector offers an improved opportunity for investment diversification by international investors. The significance of this issue is reflected in the following ways.

First, substantial regulatory efforts have been made in China to accord financial institutions a potentially significant role in improving corporate governance and stabilising the stock market over the last decade or so. Financial institutions are encouraged to acquire ownership of listed companies so that they can monitor corporate management and counter opportunistic behaviours of individual investors (e.g., free-riding problems). As a result, financial institutions have experienced a rapid growth in the past decade. For example, as at the end of 2003, there were 133 securities companies and 54 closed-end and 41 open-end

\footnotetext{
${ }^{6}$ Qualified Foreign Institutional Investors Program, effective from December 2002, offered foreign investors access to the A-shares market for the first time. This signals a significant step toward capital market opening in China. The introduction of this system brings pressure and challenge to securities investment funds.
} 
investment funds. ${ }^{7}$ The mean ownership of listed companies held by these two types of financial institutions rose to $2.13 \%$ of total shares in issue in 2003 . This thesis represents a first step towards the badly needed evaluation of the effect of financial institutions on firm performance in China.

Second, the corporate environment in China provides a potentially good setting for financial institutions to safeguard the interests of minority shareholders. The Chinese corporate sector is characterised by poor corporate governance, weak investor protection, and a highly concentrated ownership that is often dominated by a (state-owned) controlling shareholder (Sun and Tong, 2003; Wei et al., 2005). Recent "law and finance" theory highlights that a central agency problem in such a setting is the expropriation of minority shareholders by controlling shareholders (e.g., La Porta et al., 2000). Indeed, there are corporate malpractices in China (e.g., illegal insider trading, market manipulation, and corporate fraud) that are detrimental to minority shareholders (Xiao et al., 2004a). As an increasingly important control mechanism affecting corporate governance (Gillan and Starks, 2003), financial institutions aggregate the interest of many individuals and limit agency problems (e.g., expropriation of minority shareholders) by representing them as shareholders of listed companies.

Third, a review of research studies concerned with the governance role of financial institutions reveals that prior studies are invariably based on developed economies (e.g., the US and UK), while little has been undertaken in the Chinese context. This is partly because financial institutions are generally believed to play no significant role in corporate governance in China (Gen, 2002; Tenev et al., 2002). However, recent developments seem to challenge such a view. For example, institutional shareholders of Vanke Co., ZTE Corporation, COSCO Shipping Co., and Beiqi Foton Mortor Co., successfully vetoed these companies' proposed investment projects, which would otherwise harm minority shareholders. Thus, now it is ripe to conduct a systematic investigation of the current role of financial institutions in corporate governance in China.

Fourth, although researchers argue that agency theory has played a major role in transition economies (Peng, 2000, 2004; Young et al., 2002), none of the existing studies have tried

\footnotetext{
${ }^{7}$ In 2000, the government put forward an important strategic decision to devote main efforts to developing financial institutions, and investment funds are the priority. However, the Commercial Bank Law (1995, Article 43) in China forbids commercial banks to directly hold shares of listed companies.
} 
to explore the governance role of financial institutions in listed Chinese companies from an agency perspective. This thesis provides evidence to support the agency proposition in that when financial institutions play a role in corporate governance, companies with high level of their shareholdings outperform those with low institutional ownership. The findings also support the agency theory proposition that different ownership structures result in differing performance. However, the application of agency theory to China requires adequate considerations about the effect of contextual variables.

Fifth, the extant empirical studies that have tried to measure the impact of overall institutional ownership on firm performance in the Chinese context have yielded conflicting results, partly because of not distinguishing among the members of legal person investors. As discussed above, legal person investors include both financial institutions and non financial institutions. In this thesis, I distinguish two types of financial institutions (i.e., securities companies and investment funds) when examining the performance effect of institutional ownership. The results suggest that investment funds and securities companies have differing impacts on performance. That is, institutional shareholdings of investment funds have a positive impact on performance, while securities companies' shareholdings are not significantly related to firm performance.

Finally, most existing studies on the role of financial institutions in developed and emerging economies employ qualitative or quantitative methods. As discussed earlier, the results under qualitative or quantitative methods lack depth or generalisability respectively. This thesis therefore combines the two research methods to enrich the findings and provide a more comprehensive picture of the role of financial institutions in corporate governance in listed Chinese companies.

\subsection{Main findings and contributions}

The findings of this thesis suggest that Chinese financial institutions (specifically investment funds) seem to have started to play a role in corporate governance and different financial institutions have differing performance effects on listed companies.

Specifically, the interviews suggest that good performance, tradable shareholdings, financial statements and annual report, quality of management, and investor 
communications are the characteristics of companies that attract institutional investment. The results also indicate that most securities companies are passive investors, while some active investment funds help the companies in which they invest make financial forecast, standardise their practices, and improve firm performance. This limited role is attributed to a number of factors, including the highly concentrated ownership with the segmented share structure, ${ }^{8}$ premature regulatory environment, goal conflicts, inadequate transparency and disclosure of financial information, and agency problems within financial institutions themselves.

Using a large sample consisting of 1,176 companies (3,273 observations) listed on the Shanghai and Shenzhen stock exchanges over a period 2001-2003, I find that: (1) investment funds have a positive impact on firm performance and accounting performance influences their shareholdings; (2) the shareholdings of securities companies have no significant impact on firm performance. The results disprove the general perception that financial institutions in China play no role in corporate governance and indicate that different financial institutions appear to have differing impacts on firm performance.

Through a case study of how fund managers attempted to challenge a controversial proposal issued by China Merchants Bank (CMB) in which they held shares, I find that, due to the current ownership structure and weak legal protection of investors, voice from financial institutions is always ignored, and consequently they play a limited role in corporate governance. However, fund managers' unyielding action demonstrates that financial institutions (especially investment funds) have begun to play a role in corporate governance. In addition, the results indicate that the ineffectiveness of other governance mechanisms in China limits the governance role of financial institutions.

This thesis has contributed to the ongoing study of this topic in the following aspects.

Theoretical contributions. This study is among the first ones to examine the governance role of financial institutions in listed Chinese companies from an agency perspective, and has produced evidence to support agency theory. First, the results suggest that institutional

\footnotetext{
${ }^{8}$ The segmented share structure refers to the existence of a large volume of non-tradable state-owned and legal person shares (People's Daily Online, $16^{\text {th }}$ May 2005b). This means only about one-third of the shares in domestically listed firms float on the stock markets. The structure puts public investors in an inferior position relative to the actual controllers in making corporate policies and disposing of the firms' profits and assets.
} 
shareholdings of investment funds have a positive impact on firm performance while securities companies have no significant relationship with performance. In addition, state ownership has a negative effect while legal person ownership has a positive effect on firm performance. However, managerial ownership and foreign ownership have no significant relationship with performance. The evidence is consistent with the proposition that different ownership structures result in differing performance (Short, 1994).

Second, this thesis suggests that investment funds' ownership has a positive impact on firm performance, which is consistent with the notion that investment funds have the incentive and the ability to take part in the corporate governance on behalf of their investors. The results also indicate that securities companies' shareholdings do not have a significant impact on firm performance, which could reflect the problems like the recent recession, goal conflicts, and poor corporate governance that trouble securities companies.

Methodological contributions. To my knowledge, this is the first study to employ both qualitative and quantitative methods to address the practice of financial institutions' involvement in corporate governance in listed Chinese companies. In more detail, I combine the interviews, secondary data analysis, and case study to produce a more comprehensive picture of the role financial institutions in corporate governance of listed Chinese companies.

Implications for practitioners and policy makers. This thesis suggests that investment funds have a positive impact on firm performance, while securities companies have no effect on performance due to their recent recession and weak corporate governance. This indicates that the efforts of securities regulators in China in promoting financial institutions as a corporate governance mechanism seem to be beneficial to corporate governance and performance, and so should be carried on. Future efforts should be made to improve the role of securities companies in corporate governance.

In addition, as financial institutions are only one component of a larger governance 'package' consisting of internal and external mechanisms, other mechanisms need to be strengthened to improve the corporate governance of listed companies, including the board of directors, the supervisory board, and managerial incentive schemes. 


\subsection{Structure and organisation of this thesis}

The reminder of this thesis is organised into eight chapters.

Chapter Two provides theoretical considerations. Agency theory is used to analyse the Chinese institutional background, formulate research question and hypotheses, and analyse the results. It first presents an overview of agency theory. Next, it sketches agency problems, and discusses agency theory and the role of financial institutions in corporate governance. Then, it presents a critical analysis of the problems of agency theory. Finally, it discusses how agency theory is applied in this thesis.

Chapter Three reviews the current literature about effectiveness of corporate governance systems and corporate governance mechanisms outside China. Corporate governance mechanisms provide a background and contrast to discuss the interaction between financial institutions and other mechanisms such as the board of directors, the supervisory board, and independent directors in the case study chapter. The role of financial institutions as monitors of corporate governance is one of the corporate governance mechanisms and accordingly, its effectiveness depends on its interaction with other governance mechanisms and the effectiveness of these other mechanisms. This chapter first introduces market-based and bank-based corporate governance systems. Then, it discusses the effectiveness of internal and external corporate governance mechanisms. Finally, it reviews the literature about corporate governance in emerging economies.

Chapter Four reviews the prior studies about the role of financial institutions in corporate governance and its impact on firm performance outside China. It provides a theoretical background and a point of contrast with the role of financial institutions in corporate governance in China. First, this chapter briefly reviews the distinct types of financial institutions around the world. Next, it provides an overview of the role of financial institutions in corporate governance. Then, it discusses the process of institutional participation in corporate governance and identifies the factors that affect the role of financial institutions in corporate governance. Finally, it reviews the empirical studies on the relationship between institutional ownership and firm performance. 
Chapter Five introduces general background, corporate governance, and financial institutions in China. It provides an institutional background to undertake the qualitative and quantitative research. First, it reviews the Chinese economy and economic reform, the development of Chinese stock market, and the reform of state-owned enterprises and listed companies. Then it depicts the characteristics of the corporate governance of listed Chinese companies and mainly investigates the effectiveness of internal and external governance mechanisms. Finally, this chapter introduces the current context of Chinese financial institutions and reviews their role in corporate governance of listed companies.

Chapter Six is the interview evidence from both senior managers of financial institutions and board directors of listed companies. First, it provides the research questions, focusing on the characteristics of firms attracting institutional investment, the practice of financial institutions on corporate issues, and the factors affecting financial institutions to play their role. Next, it discusses research method and sample selection. Then it analyses and discusses the interview data centering on the research questions. It ends with conclusion.

Chapter Seven is the empirical evidence to test the impact of institutional ownership of securities companies and investment funds on firm performance. First, this chapter develops hypotheses and describes research design, including data sources, sample selection, variable measurement, and model specification. Then, it discusses the empirical results and robustness checks. It ends with conclusion.

Chapter Eight is a case study of how fund managers took an unprecedented collective action to challenge a controversial proposal issued by CMB. It also examines the interactions between financial institutions and other corporate governance mechanisms and highlights the problems in corporate governance. First, it introduces data sources, research method, and the background of CMB. Next, it describes the dispute between fund managers and CMB. Then, it discusses the factors that affect the outcome of the dispute, the effectiveness of other corporate governance mechanisms, the nascent shareholder activism in China, and the prospect of shareholder activism. Finally, it ends with conclusion.

Chapter Nine concludes with a summary of findings, empirical contributions, theoretical contribution, methodological contributions, implications policy makers and practitioners, limitations, and avenues for further research. 


\section{Chapter Two}

\section{Agency Theory}

\subsection{Introduction}

This thesis is guided by agency theory. Agency theory provides a set of concepts and principles that are used in this thesis to formulate research questions and hypotheses and analyse the results. Agency theory is also used to analyse the Chinese institutional background. In addition, it both sets the boundaries of, and provides a framework to organise, the literature review. Given this important role, it is necessary to discuss agency theory first. However, it is important to note that this thesis does not purport to test agency theory. Instead, it is used as a theoretical perspective or guide to examine the role of financial institutions in corporate governance in China and its impact on firm performance. Section 2 of this chapter presents an overview of agency theory. Section 3 sketches the agency problems, including traditional principal-agent problem and principal-principal problems. Section 4 discusses agency theory and the role of financial institutions in corporate governance. Section 5 provides a critical analysis of the problems of agency theory. Section 6 introduces how agency theory is applied in this thesis. This chapter ends with a summary.

\subsection{An overview of agency theory}

In the agency perspective, 'most organisations are simply legal fictions that serve as a nexus for a set of contracting relationships among individuals' (Jensen and Meckling, 1976, p310). The basic premise of the theory is that 'if both parties to the relationship are utility maximisers, there is good reason to believe that the agent will not always act in the best interest of the principal' (Jensen and Meckling, 1976, p308).

Jensen and Meckling (1976) define the agency relationship as a contract under which one or more persons (the principal(s)) engage another person (the agent) to perform some service on their behalf that involves delegating some decision-making authority to the agent. The principal has resources but it is too complicated, too costly, or impossible to manage its resources him or herself. Thus, the principal must hire an agent, who usually has 
no claims to the principal's resources but has special information and knowledge, to manage its resources. Because of the information asymmetry and the self-interest of the agent, the interest of the principal and the agent will not be consistent. The agency problems thus arise (Agrawal and Knoeber, 1996).

The essence of the agency problem is the separation of ownership and control (Berle and Means, 1932). Agency theory is concerned with resolving two problems that can occur in agency relationships. One is the 'agency problem,' which arises from conflicting goals of the principal and the agent and from the difficulty/expense involved in verifying the agent's behaviour. The problem here is that the principal cannot verify that the agent has behaved appropriately. The other is the problem of 'risk-sharing,' which arises from differing attitudes toward risk on the part of the principal and the agent. The problem here is that the principal and the agent may have different actions because of the different risk preferences (Eisenhardt, 1989).

The focus of the theory is on the contract between the principal and the agent and the ways in which the contract can be made most efficient from the point of view of the principal.

In determining the most efficient contracts, agency theory makes certain assumptions about people, organisations, and information. It assumes that agents and principals will act in their self-interest to maximise their own welfare. Further, it assumes that the agent may have an informational advantage over the principal. As a result, a pre-contract condition of adverse selection may occur as the result of hidden information, and a post-contrast condition of moral hazard may occur as the result of hidden action by the agent (Fama and Jensen, 1983b; Rasmusen, 1989). In the hidden information problems, the agent has made some observation that the principal has not made. The agent uses (and should use) this information in making decisions; however, the principal cannot check whether the agent has used his or her information in the way that best serves the principal's interest. On the other hand, the most typical hidden action is the effort of the agent. Effort is a disutility to the agent, but it has a value to the principal in the sense that it increases the likelihood of a favourable outcome (Arrow, 1985). Also, it has been assumed that maximising shareholder wealth is the goal of the firm and that managerial incentive should, in part, be based on it (Ryan and Schneider, 2003; Kim and Mahoney, 2005). In addition, the theory assumes that information about the agent is a commodity that can be pursued. 
The contract is used to mean the agreement between the principal and the agent that specifies the rights of the parties, the methods used for judging performance and the resultant pay-offs (Evans and Weir, 1995). In the light of these assumptions, agency theory seeks to define the nature of contracts that will minimise agency cost; that is the costs of monitoring, motivating and ensuring the commitment of the agent. Distinction is drawn between modes of control, one based on behaviour, and the other based on output (Ouchi and Maguire, 1975). Specifically, agency theory looks at the relative merits of behaviourbased contracts (salaries and hierarchical control) vis-à-vis outcome-based contracts (commissions, stock options, and market control) as a means of efficiently ensuring the fidelity of the agent (Nilakan and Rao, 1994). Principals minimise agency costs by monitoring agents and by creating incentive systems to align the agents' interests with those of the principals (Pratt and Zeckhauser, 1985).

In addressing conflicts of interest that arise from information asymmetry and anticipated agent opportunism, agency theorists recognise two basic attributes of exchanges with which the principals must contend: (1) cost of monitoring and (2) cost of metering (Williamson, 1985). Theorists then deploy these attributes to generate two broad ways in which principals can improve efficiency of contracts (Ouchi, 1978; Eisenhardt, 1989). First, principals can design mechanisms to monitor agent behaviour and to ensure that the agent actually is behaving as stipulated in the contract. In this way, the principal can reduce information asymmetry vis-à-vis the agent and can impose sanctions if the agent deviates from expected behaviour. An example of this type of resolution is the monitoring role of financial institutions on corporate management (Agrawal and Mendelker, 1990; McConnell and Servaès, 1990).

If agent behaviour cannot be monitored, however, principals can implement an alternative solution that is based on actual performance of the agent as measured by the outcome relative to expectations. Therefore, as Jensen and Meckling $(1976, \mathrm{p} 81)$ indicate, agency theory recommends that "the principal can limit divergence from his interest by establishing appropriate incentives for the agent and by incurring monitoring costs designed to limit the aberrant activities of the agent. In addition, in some situations, it will pay the agent to expend resources (bonding costs) to guarantee that he will not take certain actions that would harm the principal." 
Agency research has developed along two streams: principal-agent and positivist (Jensen, 1983). Principal-agent research is normative and attempts to develop the theory of agency in general, with applications to employer-employee, lawyer-client, buyer-supplier, and other agency relationships (Harris and Raviv, 1978). This stream of research tends to be very mathematical and abstract, with its modelling techniques not accessible without special training (Wild, 1994b). The positivist stream tends to focus on the contracting relationship between managers of large public corporations and its shareholders (Eisenhardt, 1989), and has been most concerned with specifying governance mechanisms that reduce agency loss. The two streams are complementary: positivist theory identifies various contract alternatives, and principal-agent theory indicates which contract is the most efficient under varying levels of outcome uncertainty, risk aversion, information, and other variables (Eisenhardt, 1989).

In summary, as Eisenhardt (1989, p59) aptly notes, "the domain of agency theory is relationships that mirror the basic agency structure of a principal and an agent who are engaged in cooperative behaviour, but have differing goals and differing attitudes toward risk."

Since it is the positivist tradition in which this study is conducted, the following discussion will focus on research within this tradition.

\subsection{Agency problem}

\subsubsection{Traditional agency problem between managers and shareholders}

The traditional agency theory assumes that ownership of a firm is well diversified among shareholders and managers of this firm have control over it, so the traditional agency problem derives from the conflicts between shareholders and managers (Jensen and Meckling, 1976). Jensen (1986a, 1989) argues that managers can expropriate shareholders by diverting corporate resources for perquisites and empire building. Indeed, managers have incentives to consume excessive salaries and perquisites and to pursue politics that protect themselves against job termination at the expense of those of shareholders. Such behaviour may be shielded from shareholders' detection, due to adverse selection or moral hazard (Rasmusen, 1989). 
Managerial self-interest may be reflected in the choices managers make regarding effort, risk exposure, and time horizons (Jensen and Smith, 1985). These choices may exert a negative impact on shareholder wealth. For example, although additional managerial effort could increase the value of the firm, managers might want to substitute leisure or overindulgence in company perquisites for that additional work effort (Jensen and Meckling, 1976). Second, in contrast to shareholders who can diversify their risk by holding a portfolio of stocks, the fortunes of top managers tend to be tied to the success of their companies (Fama, 1980). It may be in the interest of those managers, therefore, to take fewer investment risks than would be optimal for shareholders, even if in doing so they lower the aggregate market value of their company (Coffee, 1988; Morck et al., 1989). Third, even though the firm lives on, its managers do not. As a result, managers are most interested in firm performance for the time period in which they are compensated. They are likely, therefore, to have shorter time horizons than their shareholders, even if such time horizons lead to a present-value loss for the firm (Furubotn and Pejovich, 1973; Jensen and Meckling, 1979; Evans and Weir, 1995; Fosberg, 2004).

\subsubsection{Expropriation of minority shareholders by controlling shareholders}

Recent studies such as Shleifer and Vishny (1997), Holderness et al. (1999), and Claessens et al. (2000) suggest that Berle and Means' (1932) model of widely dispersed corporate ownership is not common, even in developed countries. In most countries, the typical large listed company has concentrated rather than dispersed ownership. As La Porta et al. (1998) note, dispersed ownership in large public companies is simply a myth and the textbook model of management faced by multitudes of dispersed shareholders is an exception and not the rule. Indeed, La Porta et al. (1999a) examine the largest firms in 27 wealthy economies and find that, except for the economies with solid protection for shareholders, few firms were widely held by general shareholders, with most typically being held by controlling families. Furthermore, the so-called controlling shareholders have controlling rights over cash flow rights through pyramids or participation in corporate management. La Porta et al. (1999a) also argue that the controlling shareholders are generally not monitored by other large shareholders, and that it is more common for large listed companies to have a single controlling shareholder than to have dispersed ownership.

Thus, in an economy with controlling shareholders, another kind of agency problem derives from the conflicts between the outside shareholders and the controlling 
shareholders (Shleifer and Vishny, 1997). Such controlling shareholders are in a position to exert a great deal of influence on the way the companies they own are operated, and thus to obtain private benefits of control at the expense of minority shareholders. These private benefits of control can take many forms. If the controlling shareholder is also a manager of the company, minority shareholders can be exploited by paying a high salary to the controlling shareholder. Alternatively, the controlling shareholder can exploit business relations between the company and other firms that she wholly owns in order to exploit minority shareholders. For example, transfer pricing can be used to shift profits from the company with minority shareholders to the firm wholly owned by the controlling shareholder, or the company with minority shareholders can invest in asset that are then sold or leased at favourable terms to the wholly owned firm (Johnson et al., 2000). Evidence of private benefits of control obtained by controlling shareholders has been provided for the USA by Barclay and Holderness (1989), for Sweden by Bergstrom and Rydqvist (1990b), and for Italy by Zingales (1994). For firms with a controlling shareholder, the key conflict of interest in corporate governance is thus the one between the controlling shareholders and minority shareholders, rather than between dispersed shareholders and professional managers who run the firms but have little or no ownership stake in it.

The conflict of interests between controlling and minority shareholders has received a great deal of interest in the recent literature on corporate governance. Shleifer and Vishny (1997, p759) argue that when "large owners gain nearly full control of the corporation, they prefer to generate private benefits of control that are not shared by minority shareholders." Bracing the ultimate ownership of 5,897 corporations for five West European and nine East Asian economies, Faccio et al. (2000) document that the salient agency problem in these economies is expropriation of outside shareholders by the controlling shareholder. As noted by Bebchuk et al. (1998), Claessens et al. (1999), and Wolfenzon (1999), rich possibilities for expropriation arise when the corporation is affiliated to a group of corporations. Corporation wealth can then be expropriated by the insiders who set unfair terms for intragroup sales of goods and services and transfers of assets and control of stakes (Shleifer and Vishny, 1997; Bebchuk et al., 1998; Claessens et al., 1999; Wolfenzon, 1999). La Porta et al. (1999a) conclude that the principle agency problem in large corporations around the world is the expropriation of minority shareholders by the controlling shareholders. Johnson et al. (2000) report that even in developed countries, tunnelling-the diversion of 
corporate resources from the corporation (or its minority shareholders) to the controlling shareholder - can be substantial.

The weak governance context of emerging economies also creates agency conflicts relating to expropriation of minority shareholders (Cho, 1999). Expropriation occurs within the weak governance context when large or majority shareholders assume control of the firm and deprive minority shareholders the right to appropriate returns on their investment (Shleifer and Vishny, 1988). The emerging markets crisis of 1997-1998 offers many instances of looting of firms by their controlling shareholders. Assets were transferred out of companies, profits were siphoned off to escape creditors, and troubled firms in a group were propped up using loan guarantees by other listed group members (Johnson et al. 2000). Claessens et al. (2000) identify the ownership structure of the firms in nine East Asian countries and conclude that the main corporate governance problem in these countries is the expropriation of minority shareholders by controlling shareholders. Reviewing the literature on corporate governance issues in Asia, Claessens and Fan (2002) confirms that limited protection of minority rights in Asia allows controlling shareholders to expropriate minority shareholders, and that agency problems have been exacerbated by low corporate transparency, associated with rent-seeking and relationship-based transactions, extensive group affiliation, and diversification.

\subsection{Agency theory and the role of financial institutions in corporate governance}

\subsubsection{Multiple agency contracts of financial institutions}

According to Jensen and Meckling (1976), a firm is viewed as a nexus for a set of contracting relationships among individuals. Accordingly, financial institutions can be viewed as a multi-party agency contracts (Schneider, 2000). As depicted in Figure 2.1, financial institutions function as principals to corporate management, and as agents monitoring other agents (Varian, 1990), in their intermediary role monitoring corporate management for beneficial owners (Black, 1992b; Chandar, 1996; Bricker and Chandar, 2000). Agency theory includes professional contracts, which are characterised by great information asymmetry between the two parties, where the principal relies on the professionalism of the agent to perform the contracted duties (Sharma, 1997). 


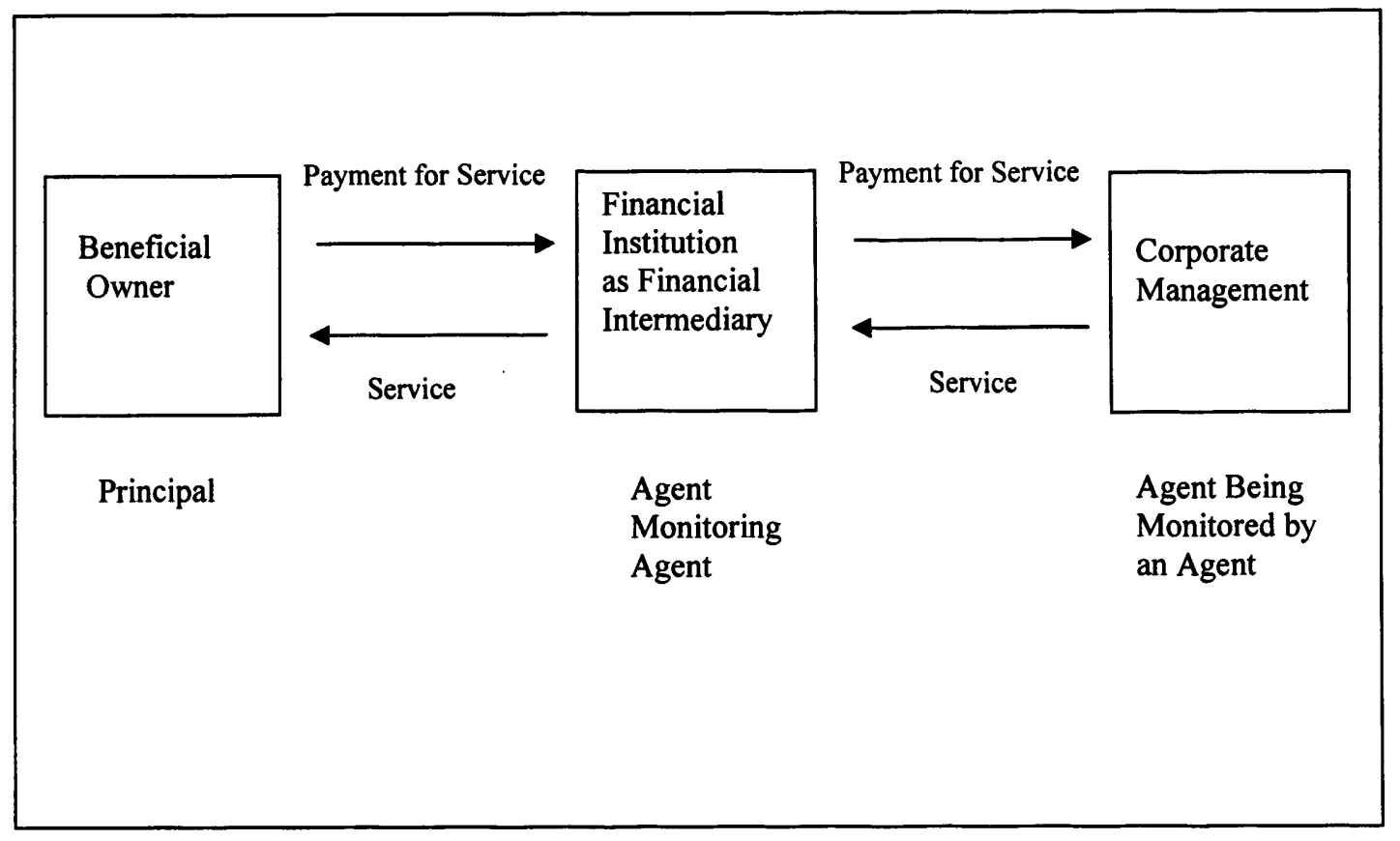

Source: Based on Chandar (1996) and Schneider (2000)

To gain the potential benefits of portfolio diversification to lower investment risk, and superior financial returns (Kolb, 1994), investors aggregate resources in financial institutions as the former often lacks the expertise to self-manage their investment, and therefore, rely on institutions' financial acumen in contract execution. The agent is hired based on specific professional knowledge or expertise and is trusted to use this expertise on behalf of the principal (Sharma, 1997).

In this setting, institutions have a fiduciary responsibility to their principals. Fiduciaries must use professional, objective judgment as to what is best for principals, act on their behalf, and avoid conflicts between their own interests and those of principals (Monks, 1997). A breath in fiduciary obligation, in which the institutions acts on its own behalf or engages in conflicts of interest, is a potential detriment to the principals. Beneficial owners must rely on the professionalism of institutional owners in upholding their fiduciary obligations and minimising agency costs.

Meanwhile, investor's agents, the financial institutions, invest these resources in firms and have agency relationships with corporate management. As financial intermediaries, institutional owners serve as delegated monitors for their principal. The fiduciary responsibility and increasing size of financial institutions provide incentives for 
institutional owners to actively monitor corporate management to ensure that managers operate on behalf of shareholders.

However, professional agency contracts illustrate another source of information asymmetry and, therefore, power asymmetry that may favour the agent (Ryan and Schneider, 2003). Since principals do not possess the technical knowledge to evaluate the effort invested or the outcome accomplished by financial institutions (Sharma, 1997), it is possible that institutional owners co-operate with corporate management on certain issues when they find it mutually advantageous. Their current or potential business relationships with the firm may make them less willing actively to curb management discretion (Pound, 1988).

In addition, the public-goods nature of corporate governance actions and the associated incentives for free riding of individual investors would suggest that monitoring of financial institutions on corporate management would not be provided.

\subsubsection{The monitoring role of financial institutions in corporate governance}

Many authors argue that the involvement of large shareholders in monitoring or control activities has the potential to limit agency problems, align the interests of agents and principals, and to monitor the behaviour of agents (Stiglitz, 1985; Huddart, 1993; Admati et al., 1994; Maug, 1998a; and Noe, 2002). These authors have further argued that, because all shareholders benefit from the action of monitoring shareholders without incurring the cost, only large shareholders have sufficient incentives to monitor.

Shleifer and Vishny (1986) argue that large shareholders, in view of their significant economic stakes, have an incentive to monitor managers. Specifically, they relate the large shareholder's behaviour to takeover related monitoring and contend that the presence of a large stockholder is necessary for value increasing takeover to occur. In their model, “...the large shareholder has a large enough stake that it pays for him to do some monitoring of incumbent management. If higher profits justify a change, he attempts to implement it" (p463).

Coffee (1991) provides an insight into the changing behaviour of financial institutions from passive investors to active monitors. He suggests that the trend towards increased activism on the part of financial institutions can be explained by the fact that exercising "voice" has 
become less costly because of the significant ownership of equity by institution and the resulting increased capacity for collective action. At the same time, following an "exit" policy has become increasingly more expensive because they must accept substantial discount in order to liquidate their significant holdings. Diamond (1984) and Noe (2002) suggest that a larger intermediary can present a better solution to agency conflicts because of economies of scale and diversification. Agrawal and Knoeber (1996) and Shleifer and Vishny (1997) assert that large investors have all the interest and the power to monitor and promote better governance of companies because of the relevance of the resources invested. David and Kochhar (1996) argue that the fiduciary duty obligates financial institutions to actively monitor corporate management.

The monitoring role of financial institutions is supported by their attempts to enhance managerial accountability through various means. Institutions have made increasing use of proxy contests, to bring about fundamental changes in management behaviour ( $O$ 'Barr and Conley, 1992). These corporate governance proposals cover issues such as the repeal of classified boards, poison pills, and other anti-takeover measures (Bhagat and Jefferis, 1988; Agrwal and Mandelker, 1990), rescinding of golden parachutes, implementing confidential voting, changing the composition of boards, and executive compensation. Institutions also have pressured management into making the boards more independent through greater outside representation (Washington Post, $4^{\text {th }}$ December 1992). Finally, institutions have sought to increase their oversight on companies through the formation of shareholder advisory committees that serve to review operating and financial results of the company and seek to enhance dialog and the flow of information between major shareholders and management. For example, the California Public Employees Retirement System (CalPERS) pressured Pennzoil Champion International to set up shareholder committee to monitor their firm performance. In other cases, institutions sought informal meetings to discuss business development on a periodic basis (Wall Street Journal, 22 ${ }^{\text {nd }}$ January 1993).

To support agency theory, empirical research examines the performance effect and other corporate issue to evaluate the efficacy of this monitoring role. In terms of the impact on firm performance, there are two assumptions about the relationship between institutional ownership and firm performance. One is performance-increased assumption, which predicts that financial institutions enhance corporate efficiency, thus improving corporate performance. McConnell and Servaes (1990, 1995), Chaganti and Damanpour (1991), 
Short and Keasey (1997), and Han and Suk (1998) provide evidences to support this assumption. The other is performance-reduced assumption. It is argued that financial institutions are passive and are more likely to sell their holdings in poorly performing companies than to expend their resource in monitoring and improving their performance. The performance-reduced assumption predicts a positive relation between institutional ownership and managerial entrenchment and consequently, a negative relation between performance and institutional ownership. Woidtke (1996), Craswell et al. (1997), Chowdhury and Geringer (2001), and Balatbat et al. (2004) support this assumption with their studies.

Actually, no matter which assumption is examined, all above studies about the relationship between institutional ownership and firm performance support the agency theory from two different sides. Some other empirical evidence on the monitoring role played by large shareholders has also provided support for this theory. For example, Bathala et al. (1994) document that institutional ownership can offset the need for debt and managerial ownership to reduce agency costs, thus suggesting that financial institutions serve as effective monitoring agents and help in mitigating agency costs. Kang and Shivdasani (1995) and Kaplan and Minton (1994) find that the presence of large shareholders is associated with increased management turnover, suggesting that these shareholders provide a monitoring function. Bethel et al. (1998) report that company performance improves after an activist investor purchases a block of shares. Moreover, Bertrand and Mullainathan (2001) find that the presence of a large shareholder on the board is associated with tighter control over executive compensation. Hartzell and Starks (2003) report that institutional ownership concentration is positively related to the pay-for-performance sensitivity of executive compensation, which suggesting that financial institutions serve a monitoring role in mitigating the agency problem between shareholders and managers.

\subsection{Problems of agency theory}

Despite its elegance, parsimony, and wide application, agency theory is not without its critics. The criticism is mainly focused on the following aspects.

\subsubsection{About the model of man}

The model of man underlying agency theory is that of a rational actor who seeks to 
maximise his or her individual utility (Jensen and Meckling, 1976). Such economic actors seek personal wealth, status, leisure, and the like (Williamson, 1985). Accordingly, their behaviour as potentially shirking or opportunistic agents can be curbed by vigilant monitoring, together with incentive schemes based around money, promotion, negative sanctions, and the like. This is a model of the Theory X variety of man (McGregor, 1960). However, there are other models of man that originate in organisational psychology and organisational sociology (Donaldson and Davis, 1991). Wood and Bandura (1989) identify a much larger range of human motives, including needs for achievement, responsibility, and recognition, as well as altruism, belief, respect for authority, and the intrinsic motivation of an inherently satisfying task. In addition, psychologists and sociologists point out that human behaviour is often produced without conscious thought, that is, through habit, emotion, taken-for-granted custom, conditioned reflex, unconditional reflex, posthypnotic suggestion, and unconscious desires.

Jensen and Meckling (1994) criticise the model of man in agency theory as being a simplification for mathematical modelling and an unrealistic description of human behaviour. Doucouliagos (1994) argues that labelling all motivation as self-serving does not explain the complexity of human action. Frank (1994) suggests that this model of man does not suit the demands of a social existence. However, Hirsch et al. (1987) highlight that in exchange for simplicity and elegance in their models, economists engage in a somewhat broad-brush approach that may reduce empirical verisimilitude and engender less than robust policies.

In addition, critics contend that not every decision situation poses a conflict of interest. Rather, many decisions occur in settings in which close alignment between managers and shareholder interests occurs without complex monitoring or incentive schemes (Cannella and Monroe, 1997; Lane et al., 1998). Davis et al. (1997) argue that assumptions made in agency theory about individualistic utility motivations resulting in principal-agent interest divergence may not hold for all managers. Instead, they introduce stewardship theory that defines situations in which managers are not motivated by individual goals, but rather are stewards whose motives are aligned with the interest of their principals.

In stewardship theory, the model of man is based on a steward whose behaviour is ordered such that pro-organisational, collectivistic behaviours have higher utility than 
individualistic, self-serving behaviours (Donaldson and Davis, 1989, 1991). According to stewardship theory, the behaviour of the steward is collective, because the steward seeks to attain the objectives of the organisation (e.g., sales growth or profitability). This behaviour in turn will benefit principals such as outside owners (through positive effects of profits on dividends and share prices) and also principals who are managerial superordinates, because their objectives are furthered by the steward. Stewardship theorists assume a strong relationship between the success of the organisation and the principal's satisfaction. A steward protects and maximises shareholders' wealth through firm performance, because by so doing, the steward's utility functions are maximised (Davis et al., 1997).

\subsubsection{About the efficient market}

Agency theorists see the firm as surrounded by efficient markets that adjust quickly to new circumstances (Williamson, 1985; Barney and Ouchi, 1986). They make the rather heroic assumption that markets are in or near an efficient equilibrium (Fama, 1980; Fama and Jensen, 1983a; Jensen, 1983).

However, the market can also be subject to friction (Williamson, 1985; Hill and Jones, 1992). The first source of friction involves the degree to which each party in its role as principal can or cannot find readily substitutable agents (Hill and Jones, 1992). Disparity in the existence of markets for agents will influence the relative power of the parties. In addition, a market for agents might bring forth monitoring devices, such as ethical codes among agents, which benefit principals by curbing agents' self-interest tendencies (Varian, 1990). The lack of a market for agents will therefore tend to lead to a higher agency costs.

Barriers to entry into and exist from contractual relationships constitute another source of friction (Porter, 1980). A further source of friction is that managers and stakeholder can to a degree shape or enact their environment (Weick, 1979).

In keeping with their tendency to ignore market friction, agency theorists tend to focus narrowly on the agency contract (Perrow, 1993), and discount the effect of contextual or institutional variables (Ryan and Schneider, 2003). Thus, agency theory should reflect a range of context (Eisenhardt, 1989) and address external factors that influence the contract (Noorderhaven, 1992). 


\subsubsection{About other stakeholders}

Agency theory has been primarily concerned with relationship between managers and shareholders, and fails to explain the nature of the implicit and explicit contractual relationships that exist between a firm's stakeholders (Hill and Jones, 1992). In addition to managers and shareholders, stakeholders include employees, customers, suppliers, creditors, communities, and the general public. Stakeholder theory is designed to examine situations in which executives pursue the best interests of corporate owners but that also includes the needs of other stakeholders (Caldwell and Karri, 2005).

The stakeholder theory concept is based on the ethical premise that "the task of management is not only to deal with the various stakeholder groups in an ethical fashion but also to reconcile the conflicts of interests that occur between the organisation and the stakeholder groups" (Carroll, 1996, p23). The theory (e.g., Freeman and Reed, 1983; Freeman, 1984; Evan and Freeman, 1988; Blair, 1995) claims that the firm should serve wider interests of stakeholders, rather than shareholders only. It overcomes some of the criticisms on agency theory by conceptualising the firm as nexus of various groups and their respective interests, and focusing on the ethics of negotiating across the diverse interests (Boatright, 1992; Clarkson, 1995). Following March and Simon (1958), each of the groups can be seen as supplying the firm with critical resources (contributions) and in exchange each expects its interests to be satisfied (by inducements). Whatever the magnitude of their stake, each stakeholder is a part of the nexus of implicit and explicit contrasts that constitutes the firm. That is, stakeholders have long-term relationships (both contributions and risk-sharing) with the firm and affect its long-term success. Their welfare must be taken into account in corporate decision-making.

Stakeholder theory argues that the current corporate governance in the Anglo-American environment fails to encourage stakeholder involvement with the firm, which indicates a disadvantage of national performance and international competition, in comparison with the corporate governance structures in Germany and in Japan (Letza et al., 2004).

\subsubsection{About the uncertainty of outcome}

As a theory of reducing uncertainty, agency theory possesses limited generalisability and 
realism (Nilakant and Rao, 1994). Outcome uncertainty in an agency relationship is associated with three factors: (1) moral hazard, where agent may expend less than optimal effort, (2) adverse selection, where agent may expend an inappropriate type of effort, and (3) the state of nature, which is outside the control of both the principal and the agent. Thus, uncertainty about the agent's effort and type and uncertainty about the state of nature create uncertainty. However, agency theory has largely restricted itself to addressing the uncertainty associated with the agent's effort. Uncertainty about agent's type has been addressed within the agency theory literature (Levinthal, 1988). Agency theory literature has addressed the uncertainty associated with the state of nature in a limited way (Baiman, 1990).

In basing uncertainty on agent's effort and type and on the state of nature, agency theory overlooks two other significant sources of uncertainty about the outcome (Nilakant and Rao, 1994). First, the relationship between the agent's effort and the outcome may be tenuous, irrespective of the state of nature. As complex organisations frequently operate with incomplete knowledge (Thompson, 1967), the actual effort-outcome relationship may deviate significantly from the prescribed relationship. Second, in agency relationships where there are several principals and/or agents, goal conflicts among the principals and/or the agents can result in outcome uncertainty. Business organisations pursue multiple and occasionally incompatible goals (Shetty, 1979). According to the role-set theory, when several roles are to be enacted by the same person, the role-taking process becomes increasingly complex and may result in role conflicts defined as "... the simultaneous occurrence of two or more role expectations such that compliance with one would make compliance with other more difficult" (Katz and Kahn, 1978, p204). In such settings, variations in outcome may reflect multiple goals rather than effort aversion. Similarly, when there are multiple agents, lack of agreement about outcome and type of effort may result in uncertainty about the outcome (Nilakant and Rao, 1994).

In addition, agency theory is concerned with strategies and mechanisms to reduce uncertainty, however, contract design is not the best means of doing so (Nilakant and Rao, 1994). Other mechanisms, which are structural and cultural, aim to reduce uncertainty in performance through organisation design, trust, and collaboration. Structural mechanisms such as boundary spanning roles, task forces and teams, liaison and integrator roles, and matrix structures aim to reduce uncertainty created by interdependence (Orsburn et al., 
1990). Cultural mechanisms have emphasised shared values, traditions, beliefs, and commitment (Ouchi, 1980; Trice and Beyer, 1984).

In summary, the main criticism on agency theory focuses on its model of man, its assumption of an efficient market, failure to acknowledge other stakeholders, and shortcoming in acknowledging uncertainty.

Although stewardship theory explains a different type of human behaviour from that of agency theory, its model of man is simple and unrealistic as well. Whereas agency theory is derived from the economic model of man (i.e., Theory X), stewardship theory is derived from the Theory Y streams of organisation behaviour research (McGregor, 1960). Traditionally, human motivation has been viewed as neither wholly Theory X nor Theory Y, but as some more complex and contingent admixture of the two (Schein, 1970; Miner, 1980). Furthermore, stewardship may be valid within its own domain (Donaldson, 1990). For example, stewardship theory may prove correct as long as the coalition (Cyert and March, 1963) between managers and owners persists. Under conditions where the existing coalition is called into question, such as by a takeover threat, the interests of each party start to diverge. Thus, stewardship theory also has limitations.

On the other hand, stakeholder theory succeeds in recognising the many parties that constitute the firm, but it has not yet acknowledged the primacy of the profit obligation to owners (Schneider, 2000). Sufficient profit for owners is necessary for firm survival. Without it, there is no firm, and no stakeholder interest can be fulfilled. Stakeholder theory treats owners as one of the several critical stakeholder groups, but fails to recognise that owners provide the foundation of the firm for all of its stakeholders. Further, Stoney and Winstanley (2001) criticise that the term stakeholding has become content free and can mean almost anything the author desires (what Keenoy (1999) terms a hologram). Hay (1996, p47) makes this point explicitly when he describes Hutton's (1995) much-publicised blueprint for a stakeholder society as 'a rather vague and cryptic concept which is open to a wide variety of rather divergent political interpretations.' Stoney and Winstanley (2001) further argue that the vagueness of the stakeholder concept can be attributed to some major factors including the failure to clarify its theoretical underpinnings and the ambiguity surrounding overall aims and objectives. In addition, Key (1999) addresses four criticisms about Freeman's (1984) stakeholder theory, i.e., inadequate explanation of behaviour within 
its environment, incomplete linkage of internal and external variables, insufficient attention to the system within which business operates and the level of analysis within the system, and inadequate environmental assessment.

\subsection{Agency theory and this thesis}

There is a long and developed research tradition that examines the relationship between the monitoring role of large shareholders (either active monitor or by virtue of their mere presence) and firm performance within Anglo American firms. The notion comes from the agency theory that concerns that the interests of owners and managers may not coincide (Jensen and Meckling, 1976).

Agency theory asserts that the delegation of managerial responsibilities by principals to agents requires the presence of mechanisms that either align the interests of principals and agents or monitor the performance of managers to insure that they use their delegated power to generate the highest possible returns for the principals. It has been argued that weak governance and limited protection of minority shareholders intensity the traditional principal-agent problems in transition economies (Dharwadkar et al., 2000).

Despite the fact that agency perspective is central to research on the institutional ownership-firm performance relationship in developed economies, it has been criticised extensively for being incomplete or unrealistic (e.g., Band, 1992), as discussed above. Nonetheless, agency problems associated with the separation of ownership and control are central to transition economies (Judge et al., 2003). Indeed, recent research suggests that there is not only a principal-agent problem in transition economies, but also principalprincipal (e.g., majority-minority shareholder) problems (Young et al., 2002). Since the monitoring role of institutional shareholders is a primary mechanism within the corporate governance literature and agency theory is a prevailing theory, strong practitioner supports in the West and widespread application in transition economies, I use agency theory as the theoretical framework in this thesis.

On the other hand, institutional ownership is unique. First, institutional ownership is a unique type of financial intermediation, because it involves equity contracts, and challenges the existing theory of intermediation, which is largely based upon depository institutions and debt contracts (Allen and Santomero, 1998). Second, given the intermediary role that 
financial institutions play, and the fiduciary obligations with the role, institutional ownership is a unique ownership, different from non-institutional ownership. Institutional owners are the owners of record of a segment of total corporate equity. However, much of this is not held for the institutions themselves; it is held by the institutions as financial intermediaries on behalf of the funds' beneficial owners. Being a financial intermediary entails fiduciary responsibilities, which obligate financial institutions to closely monitor their holdings and take action to protect investments against erosion in value. As a result, financial institutions not only play an intermediary role between beneficial owners and corporate management, but also take the concomitant responsibilities to serve as delegated monitors for their principals (Diamond, 1996). Furthermore, while institutional owners bring professional expertise and norms to the contract, they are complex organisations, or political systems of competing interests (Mintzberg, 1983). Accordingly, institutional owners have own goals, separate from the goals of their principals (Garten, 1992). In addition, as financial intermediaries, institutional owners exist within a legal framework that is unique to them, and the agency contract between principals and institutional owners is affected by law and regulations regarding to financial intermediaries that do not apply to individual ownership.

Therefore, a model of institutional ownership should reflect both the primacy of ownership claims on the firm but also the information asymmetries that may exist between principals and institutional owners (Schneider, 2000). Agency theory is important in developing such a model, as the former consideration is recognised in agency theory's general application to ownership, and the latter in application of agency theory to professional contracts (Sharma, 1997).

In addition, as discussed above, it appears that no theory is perfect. However, agency theory seems to be able to provide a more conducive basis for analysing the role of financial institutions in corporate governance compared with the two other theories. If the motives of managers are aligned with objectives of shareholders, there is no opportunity for financial institutions to serve as delegated monitors for their beneficiary owners. Meanwhile, as stakeholder theory is fundamentally normative (Donaldson and Preston, 1995), it does not adequately explain the firm's behaviour and the linkage of internal and external variables. Consequently, it can be implied that the stakeholder theory cannot fully explore the relationship between governance mechanisms and the firm. 
Overall, this thesis uses agency theory as the theoretical framework to address the monitoring role of financial institutions. In addition, agency theory will also be used in reviewing the literature and analysing the Chinese institutional background. Its application is further expounded below.

Literature review. Agency theory sets the boundaries for the literature review. The literature about the effectiveness of corporate governance mechanisms and the role of financial institutions is mainly based on agency theory. Internal mechanisms are exercised on behalf of shareholders to bring the interests of managers and shareholders into congruence. If a company's internal mechanisms fail, external mechanisms acts as disciplining devices. Among governance mechanisms, the involvement of large shareholders in corporate governance increases firm value by limiting agency problem and pressuring managers to adopt value-increasing policies.

Institutional background. Agency theory is used to highlight the main agency issues and problems associated with particular Chinese features such as dominance of state ownership, non-tradable shares and concentrated ownership. It is also used to identify and discuss mechanisms that have been used to alleviate these problems. Agency theory is also used to analyse agency problems within financial institutions. China is a developing country with the characteristics of a transitional economy as well as an emerging market economy. The ineffective state ownership, entrenchment of managers, and expropriation of minority shareholders by controlling/majority shareholders become the agency problems of Chinese companies. However, the ineffective corporate governance mechanisms cannot restrict the agency problems. Most financial institutions are still state-owned and suffer the same problem as listed companies, such as collusion.

Empirical analysis. Based on agency theory and on the extant literature, the primary research question arising out of this thesis relates to the role of Chinese financial institutions in corporate governance of listed companies. To answer this question, interview study mainly explores the actual role of financial institutions in corporate governance and the factors that influence this less-than-desirable role of Chinese financial institutions in corporate governance.

Meanwhile, agency theory provides a theoretical basis for formulating hypotheses and 
analysing the results. The poor internal corporate governance, conflicts of interest, and poor business performance might hurt securities companies' incentive and their ability to monitor corporate management, thus I predict that securities companies' ownership is likely to have no significantly positive effect on firm performance. By contrast, as investment funds appear to have more incentives to actively participate in the corporate issues, they are likely to have a positive impact on firm performance. Indeed, this is supported by the recent anecdotal evidence on investment funds' attempt to veto corporate investment decisions. Hence, I predict a positive relationship between investment funds' ownership and firm performance.

As predicted, investment funds' ownership has a positive impact on firm performance. The result is consistent with the notion that investment funds have the incentive and the ability to take part in the corporate governance on behalf of their investors. The results also indicate that securities companies' shareholdings do not have a significant impact on firm performance, which could reflect problems like the recent recession, conflicts of interest, and poor corporate governance that trouble securities companies. The findings suggest that different financial institutions appear to have differing impacts on firm performance.

In the case study, agency theory is used to explain the outcome of the dispute between fund managers and the portfolio company, as well as the interactions between the governance role of financial institutions and other corporate governance mechanisms. It also provides the theoretical basis for analysing the principal-principal problems. Due to the lack of effective monitoring mechanisms, controlling shareholders and the management usually exert excess control on the company in China. This facilitates opportunistic behaviour aimed at pursuing private gains rather than the best interest of the company and shareholders. This case illustrates the expropriation of minority shareholders by majority shareholders.

\subsection{Summary}

Agency problems arise because managers have the opportunity to use the resources of the firm in ways that benefit themselves personally but decrease the wealth of the firm's shareholders. However, in an economy with controlling shareholders, another kind of agency problem derives from the conflicts between the outside shareholders and the controlling shareholders (Shleifer and Vishny, 1997). 
Agency theorists argue that the involvement of large shareholders in monitoring or control activities has the potential to limit agency problems. Empirical evidence on the monitoring role played by large shareholders has provided some support for this theory.

Despite its elegance, parsimony, and wide application, agency theory is not without its critics. The theory's model of man is criticised as being an unrealistic description of human behaviour, the theory ignores market friction and fails to acknowledge other stakeholders, and the theory's application to organisational phenomena has been criticised for shortcomings in acknowledging uncertainty. Although stewardship theory and stakeholder theory overcome some of these criticisms, they possess their own limitations.

Nevertheless, compared with the other theories, agency theory seems to be more instrumental in analysing the role of financial institutions in corporate governance, as well as review the literature and the institutional background. Thus, this thesis is conducted on the base of agency theory.

To address the limitations of agency theory, I undertake the interviews first to provide a background for secondary data analysis and case study. Therefore, I depend on agency theory and China's background of financial institutions to formulate testable hypotheses on, and explain the results from quantitative analysis of, the role of financial institutions in corporate governance.

The next chapter will discuss the two main corporate governance systems around the world and the effectiveness of internal and external corporate governance mechanisms. 


\section{Chapter Three \\ Literature Review Part I \\ Effectiveness of Corporate Governance Systems}

\subsection{Introduction}

The previous chapter discusses agency theory, which provides a basis for the development of corporate governance systems and various governance mechanisms.

Modern corporations in capitalist economies are frequently described as a nexus of contracts among stakeholders of many types - stockholders, creditors, managers, workers, suppliers, local communities, and the public. While these diverse groups have a strong incentive to cooperate in order to exploit their individual welfare, they also frequently tempt to exploit the corporation's resources to foster their own individual interests at the expense of others. Various systems of corporate governance have evolved in different countries to attenuate these hazards of self-interested behaviours.

Recent research has viewed the concept of corporate governance in different ways. For example, Demb and Neubauer (1992) define corporate governance as the process by which corporations are made responsive to the rights and wishes of stakeholders. Monks and Minow (1995) define corporate governance in terms of relationship among various participants. Tricker (1994b) states that corporate governance addresses the issues facing boards of directors, such as the interaction with top management, and relationships with the owners and others interested in the affair of the company, including creditors, debt financiers, auditors and corporate regulators. From agency perspective, corporate governance is a response to the agency problems that arise from the separation of ownership and control in a corporation (Boubakri et al., 2005), and encompasses a set of institutional and market mechanisms that induce self-interested managers to maximise the value of the residual cash flows of the firm on behalf of its shareholders.

The purpose of this chapter is to highlight where this thesis resides within the voluminous literature regarding corporate governance. This chapter does not attempt a review of all existing empirical research in this area, but supplies a setting for the study in relation to the 
corporate governance research tradition. In this sense, it is a selective literature survey that condenses the relevant extant research and focuses the attention on the immediate issues. In addition, corporate governance mechanisms provide a background and a contrasting point for discussing the interaction between financial institutions and other mechanisms in the case study chapter. The role of financial institutions as monitors of corporate governance is one of the corporate governance mechanisms and accordingly, its effectiveness depends on its interaction with other governance mechanisms and the effectiveness of these other mechanisms.

The remainder of this chapter is organised as follows: Section 2 introduces two main corporate governance systems, i.e., market-based and bank-based. Section 3 discusses the effectiveness of internal and external corporate governance mechanisms. Section 4 presents a discussion about corporate governance in emerging economies. The final section provides a summary.

\subsection{An overview of corporate governance systems}

\subsubsection{Market-based system versus bank-based system}

In the systems of corporate governance literature one can organise the variety of variables and concepts used to describe the complexity of corporate governance mechanisms into two main categories: market-based and bank-based. The market-based aspects contain, among others, variables like well-developed financial markets, widely dispersed ownership structure, active market for corporate control, and outsider dominated boards of directors. Exponents of the market-based system are the Anglo-Saxon countries like the United States, the United Kingdom, Canada, and Australia (Moerland, 1995).

The bank-based aspects refer mainly to closely held corporations, group membership of corporations, substantive involvement of universal banks in financing and controlling corporate firms, long period relationship, and small external market for corporate control. The representatives of this model are Germany and Japan.

Based on this organising principle, the following subsections further explore the concepts mentioned above and other key aspects of each corporate governance system. 


\subsubsection{Market-based system in the US and UK}

The market-based system appears to emphasise the role of a free market, relying on the market to exert control for corporate owners. The corporate concept is based on a fiduciary relationship between shareholders and managers (Cernat, 2004).

Corporate governance in the U.S model is based in a "property conception" (Allen, 1992). Under this view, managers run a firm to maximise the return for its shareholders, who bear the residual risk. Shareholders are seen as owners who have the right to possess and use property or to transfer all or part of it in open markets. The norm of shareholder wealth maximisation creates a structure in which managers and directors of a corporation act as the agents for shareholders and the managers are ultimately held accountable to a corporation's shareholders. Shareholders - individuals and institutional - are the primary owners and most important participants in the US system and shareholder wealth maximisation remains the predominant norm.

A distinctive feature of the British corporate governance system is that it strongly resembles its counterpart in the US (Cheffins, 1999). For instance, both countries have well-developed equity markets, with most major business enterprises being quoted on a stock exchange (Moerland, 1995). Neither country has an inside/control-oriented system of ownership and control. Instead, matters are configured on an 'outsider/arm's length' basis (Goergen, 1998), with publicly traded shares being the norm in bigger firms and with dispersed and passive share ownership being the order of the day in stock market companies (Cheffins, 2004). Share ownership is dispersed throughout a large number of institutional and individual investors rather than being concentrated in the hands of family owners, banks, or affiliated firms. Investors in the US and the UK are rarely poised to intervene in running a business. Instead, they tend to maintain their distance and give executives a free hand to manage (Cheffins, 2001). When they feel one of their companies is poorly managed, portfolio manager always follow "the Wall Street Rule" - to sell their shares and get out rather than encourage the firm to change its policy.

Recently, several factors have led institutions to deviate from this policy and to become more active in corporate governance (Short and Keasey, 1997). One particularly important factor is the increasing size of financial institutions in recent years (Carleton et al., 1998). 
As concentrated owners, financial institutions are beginning to wield their power by influencing firm policies, participating in firm decision-making, and exercising their voting rights to control managers' actions (Duggal and Millar, 1999).

However, corporate governance in the UK is unique as well, as the separation of ownership and control has followed a very strange path in the UK (Murphy and Topyan, 2005). Separation occurred, ownership dispersed, but originating families retained board control. It is argued that the takeover process, as the main driver of growth of and dispersion of equity, is responsible for this outcome (Frank et al., 2003).

\subsubsection{Bank-based system in Japan and Germany}

The bank-based system seems to emphasise on the business network, in which the interdependent, mutual self-interests of all parties serve as checks on one another. In this system, the corporation, as a wealth-producing entity, is emphasised over both the market and the conduct of business within the market.

Japanese and German governance are founded on relationships (Rubach and Sebora, 1998). Relationships are a mechanism used to ensure long-term, mutually beneficial exchanges between owners and corporate managers. The extensive cross-ownership relationships through equity holdings, acquisitions, alliances and research consortia have been identified with operational efficiencies. The information sharing and commitment help to align owner/manager goals and lessen agency problems. The relationships permit owners to influence management directly, not just indirectly by buying or selling their shares. The main bank presence makes financial governance systems more efficient and lowers risk costs of capital, thus creating competitive advantages.

One of the most salient and enduring characteristics of the Japanese corporations is their tendency to engage in close, long-term business relationship with other firms (Yoshikawa, 2001). This particularly characterises their banking relationships, but also their dealing with suppliers, subcontractors, and large corporate customers. Many of these in turn have longstanding relationships with one another, resulting in an intricate network of firms connected by formal and informal commercial and financial commitments. This corporate network is expressed in the Japanese keiretsu - a complex pattern of cooperative and competitive 
relationships, characterised by shareholder interlocks and cross-holdings of debt and equity. The system of cross-holdings is a defensive tactic that protects against hostile takeovers, reduces opportunism among participants, and preserves long-term business relationships. These relationships encourage collaboration, including extensive inter-group trade and long-term commitment.

Japanese corporations have traditionally placed greater reliance on banking financing. Many Japanese corporations have a commercial bank, called main bank, among their major stockholders. Aoki et al. (1994) suggest that although firms normally operate autonomously, the main bank is responsible for monitoring firm performance and often intervenes when profitability is poor. If the corporation is profitable, then the banks will act only as monitors and protectors of outside interests. However, Japanese banks will intervene in corporate governance when firms underperform. Banks have "appointed" directors to boards of companies in which they invest based upon the efficiency-related determinants of poor stock performance and low earnings. This oversight function internalises the market for corporate control freeing managers except in times of crisis (Gilson and Roe, 1993). In Japan, government bureaucrats are stakeholders and affect corporate policy through active government intervention.

The Japanese governance system focuses on the transaction network rather than returns to individuals. The main bank system is generally stable, with management often entrenched and insulated. Two factors reinforce this condition: (1) the passivity of shareholders, and (2) a predominance of inside directors. Japanese boards of directors tend to mirror their shareholders, whose interlocking interests insure managers are elected as board members (Pinkowitz and Williamson, 2001).

In German corporate governance, the corporation is seen as a combination of various interest groups whose goals have to be coordinated in the national interest (SchneiderLenne, 1993). Banks enjoy a special position in German industry. The historically underdeveloped capital market and burdensome corporate tax policy have inclined to firms to finance with bank debt rather than equity. German banks also own a significant fraction of equity in non-financial firms. In addition to direct share ownership, banks serve as depositories for stock owned by other shareholders. Banks also enjoy the right to vote shares held on deposit on behalf of the depositors. Big commercial banks and central 
savings banks practice universal banking, which includes direct investment in equities and bonds. As a result, German bankers hold directorships on the supervisory boards of the firms. German commercial banks, facilitated by law and tax policy, own sizeable portions of many large industrial firms. Ownership gives it the power to block any change in the firm's statues. This has resulted in a concentration of ownership among major banks.

Therefore, a German main bank plays a "universal" role: it is a firm's principle bank for the lending business, a member of its issuing syndicate, a manager of large portfolios of private investors, a shareholders, a voter of shares under the depository scheme, and a holder of seats on supervisory boards. These roles lead to information, consultation, and corporation, which guarantee bank participation in business decisions. In addition, alliances, including interlocking directorates between banks and business and commercial enterprises, are quite prevalent. Main bank involvement has created a stable structure where managers can pursue medium- and long-term corporate objectives.

A feature quite different from other countries is that German corporate governance has a dual board system. The dual board consists of a supervisory board and an executive board. The dual board structure is viewed as a mechanism for controlling and monitoring management. It also serves to shield management against takeover.

\subsubsection{Weaknesses in the governance systems}

Different markets function to monitor and restrict management behaviour, including markets external to the corporation (e.g., the market for corporate control, the product market, and the managerial labour market) and internal to the corporation (e.g., an effective, independent board of directors, equity ownership by managers, and active shareholders). There are, however, problems associated with both the external and internal mechanisms, and these are apparent in the governance systems of the US, UK, Japan, and Germany.

Neither system provides perfect mechanisms to reduce agency costs, nor is it foolproof. Moreover, each model has exhibited an inability to act quickly and to act in a non-crisis situation. While the product market will ultimately determine the survival and success of a company, the results usually take years to exhibit themselves. The merger mania of the late 1980s in the US demonstrated that market for corporate control is quite costly and often 
disregards its effects on both human and social capital. A criticism of the internal and external mechanisms is that they are too slow to react or react only to crises.

In Japan and Germany, relational structures have foreclosed the market as an effective monitoring mechanism. Moreover, relationship investing reduces firms' ability to create or even cope with change and permits firms in mature industries to be inefficient in the allocation of resources (Yafeh, 2000). Weinstein and Yafeh (1998) argue that Japanese banks exert influence on the behaviour of client firms, and this influence, which is not restricted to periods of financial distress, is designed to serve the bank's interests as a major lender, leading to non-profit maximising behaviour of the firm. Banks induce clients to borrow more than profit maximisation would warrant, and, in addition, banks seem to influence client firms to adopt low-risk and low-return investment strategies, resulting in poor performance.

A similar argument is made by Morck and Nakamura (1999), who claim that assigning the task of corporate governance to banks, as has traditionally been done in Japan, does not always lead to maximisation of firm value because banks as creditors have different objectives from banks as shareholders. For example, banks intervene in the operations of client firms if their cash flow or liquidity is low, but not necessarily when share-price performance is poor. Moreover, Kang and Stulz (2000) report that, during the 1990s, bankdependent Japanese firms experienced worse stock price performance than other firms. ${ }^{9}$ Minoru Makihara, CEO of Mitsubishi Corporation, has characterised Japan's recent financial ills as a "governance recession," in which Keiretsu system has demonstrated its inefficiencies by its inability to deal with changes in world business.

In Germany, the involvement of financial institutions in the corporate sector has ambiguous effects on the affected companies' performance (Boehmer, 2000). Given that on average banks extend substantially more debt than equity to listed companies, they clearly have incentives to maximise the value of debt, as opposed to that of equity. At least since Jensen and Meckling's (1976) analysis of agency problems, it is basic knowledge in financial economics that creditors and shareholders have distinctly different interests. Therefore, banks represent prior poor candidates for representing shareholders at annual general

\footnotetext{
${ }^{9}$ See Andersen and Campbell (2004) for a more detailed discussion of Japanese bank governance.
} 
meetings, especially when their voting rights come from proxy votes and not from direct shareholdings. Boehmer (1999) provides empirical evidence that bank involvement appears to have a very limited effect on performance. Since it has no discernible positive effect on listed firms empirically, it is hard to support the claim that the interests of small shareholders are well represented via the proxy-voting mechanism. In a similar vein, Franks and Mayer (1998) report that banks in several hostile takeovers in Germany did not act in shareholders' interest. Furthermore, the dual board system in Germany has also failed as a monitor. It did not prevent the collapse of Metallgesellschaft (Tricker, 1994a). Similarly, Pirelli's 1990 attempted advantageous takeover of Continental was significantly impeded by its need to deal with both components of the dual board structure of German governance (Rubach and Sebora, 1998).

Summing up, market-based as well as bank-based models incorporate both advantages and disadvantages. One cannot say that one system is superior over the other on theoretical grounds. Advantages of one system will be generally disadvantages of the other, vice versa. In view of the dramatically increased interest in corporate governance, it can be observed that changes are taking place in both systems, and a kind of convergence appears to occur (Moerland, 1995).

\subsection{Corporate governance mechanisms: internal versus external}

Agency theory focuses on the information systems and other monitoring devices that can be designed and employed to align the interests of mangers with those of shareholders (Wild, 1994b). The various monitoring mechanisms may be classified as internal or external (Walsh and Seward, 1990). An essential characteristic of internal mechanisms is that the responsibility for monitoring falls to insiders (e.g., owners, or the board of directors) who are directly charged with responsibility for corporate governance. What is common to the external mechanisms is that they rely on a variety of markets or market-based measures to align the competing interests and thus, when effective, render monitoring of managers unnecessary.

Internal mechanisms largely emanated from the board of directors, are exercised on behalf of shareholders (owners) and bring the interests of managers and shareholders into congruence. External mechanisms pertain to the role of markets in monitoring and disciplining managers. The most widely noted external mechanism is the market for 
corporate control (Jensen, 1989), and other market-related mechanisms arise from managerial labour markets, legal system, and external auditing.

The purpose of modern corporate governance is to increase shareholder and economic wealth in a sustainable way, to align the interests of board, management, shareholders and to provide timely and accurate information to facilitate accountability to shareholders and other stakeholders (Healy, 2003). Major contributions of corporate governance to the company include enhancing operating performance and preventing fraud (Yeh et al., 2002). Corporate performance is crucially dependent on the efficient operation of internal and external corporate control mechanisms. Black (2001), Black et al. (2002), Gompers et al. (2003), and Joh (2003) find a positive correlation between performance measures and governance level. A sound corporate governance structure not only provides useful information to investors and creditors to reduce information asymmetry, but also helps the company to improve operations. Primarily based on the developed economies, prior empirical studies about the relationship between firm performance and corporate governance mechanisms have yielded mixed results.

\subsubsection{Internal mechanisms}

\subsubsection{Ownership structure}

According to Jensen and Meckling (1976), ownership structure refers to the relative amounts of ownership claims held by insiders (management) and outsiders (investors with no direct role in the management). As one of the important internal mechanisms, share ownership and its structure can be important sources of incentive for management, boards of directors and outside shareholders (Milgrom and Roberts, 1992). The pattern and amount of stock ownership can also influence managerial behaviour, firm performance, and stockholder voting patterns in election contests (Grossman and Hart, 1988). The connection between ownership structure and performance has been the subject of an important and ongoing debate in the corporate finance literature. The empirical studies about the relation between both variables seem to have yielded conflicting results.

Ownership concentration. Early studies beginning with Berle and Means (1932) tend to find a positive association between ownership concentration and accounting profitability (Cubbin and Leech, 1983). However, Demsetz (1983) argues theoretically that ownership 
concentration is an endogenous outcome balancing the costs (e.g., risk) and benefits (e.g., monitoring) of ownership. In support of this hypothesis, Demsetz and Lehn (1985) find the relationship between ownership concentration and accounting profitability to be insignificant when controlling for other variables. The same conclusion was reached in a study of majority-owned companies by Holderness and Sheehan (1988). Murali and Welch (1989) and Denis and Denis (1994) find no evidence to suggest that performance differs between majority-owned firms and diffusely owned firms. Subsequent studies on international data have supported the Demsetz-Lehn model (BergstrÖm and Rydqvist, 1990a; Gerson and Barr, 1996; Pedersen and Thomsen, 1999; Chirinko et al., 2004), although Gedajlove and Shapiro (1998) and Pedersen and Thomsen (1999) find that the performance impact of ownership structure depends on system effects.

In contrast, more recent studies on stock market data have continued to find a positive ownership concentration effect. Lloyd et al. (1987) find the company market value-to-sales ratio to be greater for 'owner-controlled' companies with concentrated ownership. Working with a sophisticated index of owner influence as a function of concentration, Leech and Leahy (1991) reach the same conclusion. Zeckhouser and Pound (1990) find that the price/earnings ratio increases with ownership concentration in industries that they categorise as 'easy to monitor' and where owners can therefore presumably affect performance. More recently, using a sample of 209 privatised firms from 39 countries over the period 1980 to 2001, Boubakri et al. (2005) find that firm ownership concentration is positively related to firm performance, and this effect of ownership concentration on firm performance is stronger in those countries in which investor protection is weaker.

Managerial ownership. Berle and Means (1932) point out the potential conflict of interest between corporate managers and dispersed shareholders when managers do not have ownership interest in the firm. Various aspects of this problem have been emphasised by Baumol (1959), Marris (1964), Williamson (1964), and Jensen (1986a), among others. 'Convergence of interest' hypothesis (Jensen, 1993) suggests that managerial ownership help align the interests of shareholders and managers, and as the proportion of managerial equity ownership increase, so does firm performance. The argument is that with a higher fraction of shares in hand, the management may work harder to improve the performance of the corporation, which leads to an increase in firm value and hence an increase in the managers' private wealth. Thus, the value of the firm depends on the fraction of shares 
owned by insiders. The greater the proportion of the shares owned by insiders, the greater the value of the firm. While 'entrenchment' hypothesis predicts that corporate assets are more likely to be squandered by managers who become 'entrenched' by virtue of their large stockholdings in the firm. Demsetz (1983) and Fama and Jensen (1983a) argue that when managers own only a small stake, market discipline may force them towards value maximisation. In contrast, managers who control a substantial fraction of the firm's equity may have enough voting power or influence to ensure that their position inside the company is secure. As a result, they may become to a great extent insulated from external discipline forces such as the takeover threat or the managerial labour market.

Numerous studies have sought to empirically distinguish between the hypotheses by examining the relation between managerial ownership and firm performance. McConnell and Servaes (1990) examine the relation between Tobin's Q and insider and blockholder ownership in two different cross-sectional samples. They find a significantly positive relation for insider ownership between 0 and 5 per cent, but fail to confirm the findings of Morck et al. (1988) for insider ownership beyond 5 per cent. No significant relation is found beyond 5 per cent. Hermalin and Weisbach (1988) estimate the effect of managerial ownership on $\mathrm{Q}$. They find a significant non-monotonic relation between managerial ownership and performance, a positive relation between 0 and 1 per cent, a decreasing relation between 1 and 5 per cent, and increasing relation between 5 and 20 per cent, and decreasing beyond 20 per cent. Loderer and Martin (1997) use acquisition data to estimate a simultaneous equation model in which $\mathrm{Q}$ and insider holdings are endogenous. Insider ownership fails to predict $\mathrm{Q}$, but $\mathrm{Q}$ is a (negative) predictor of insider ownership.

Cho (1998), using cross-sectional data and ownership information from value line, first replicates Morck et al.'s study and finds a similar non-monotonic relation between $Q$ and management share holdings. However, he then estimates a system of three equations in which insider ownership depends on $\mathrm{Q}$, investment, and a set of control variables, $\mathrm{Q}$ depends on insider ownership, investment and a set of control variables, and investment depends on insider ownership, Q and a set of control variables. His estimates for this system of equations indicate that $\mathrm{Q}$ affects ownership structure, but not vice-versa. Himmelberg et al. (1999) extend Demsetz and Lehn's study by adding new variables to explain the variation in ownership structure. They find that insider ownership is negatively related to the advertising-to-sales and operating income to sales ratios. Controlling for these 
variables and fixed firm effects, they find that changes in ownership holdings have no significant impact on performance. When they control for endogeneity of ownership by using instrumental variables, they find a quadratic form of the effect of ownership on performance.

Holderness et al. (1999) replicate for 1935 and 1995 central aspects of the Morck et al. study and Demsetz and Lehn's study. As in Morck et al., they find a significant positive relation between firm performance and managerial ownership with the 0-5 per cent range of managerial shareholdings but, unlike Morck et al., they do not find a statistically significant relation beyond 5 per cent managerial shareholdings. Demsetz and Villalonga (2001) examine the roles played by two aspects of ownership structure, the fraction of shares owned by the five largest shareholding interest and the fraction of shares owned by management, and it modes these as endogenous. They find no statistically significant relation between ownership structure and firm performance.

While most studies examining the relation between managerial ownership and performance have used US data, Short and Keasey (1999) examine the relation for UK firms. They find that management becomes entrenched at higher levels of ownership in the UK than in the US. They suggest that different governance mechanisms in the two countries could explain these differences.

Intermediaries and outside blockholders. Outsider blockholders and intermediaries generally act as monitors and may be instrumental in generating superior firm performance (Singh and Davidson, 2003). ${ }^{10}$ In theory, Diamond (1984) and Noe (2002) suggest that a larger intermediary can present a better solution to agency conflicts because of economies of scale and diversification. Admati et al. (1994) argue that when monitoring is costly, the intermediary will monitor only if this will result in a modification in firm's payoff structure and lead to net gains. When the intermediary does not hold all the firm's equity and the transaction costs are not excessive, the level of commitment will be sub-optimal even when optimal risk-sharing is attained. Maug (1998a) extends this analysis and argues that liquid markets reduce large shareholders incentive to monitor because they can sell their holdings easily, but such market makes corporate governance more effective as it is cheaper and easier to acquire and hold large stakes. Kahn and Winton (1998) distinguish between

\footnotetext{
${ }^{10}$ The relationship between institutional ownership and firm performance is discussed in detail in the next chapter.
} 
liquidity, speculation, and intervention and argue that intervention is a function of the size of institution's stake, firm specific factors and institution's trading profit. Agrawal and Knoeber (1996) and Shleifer and Vishny (1997) suggest that large investors, because of the relevance of the resources invested, have all the interest and the power to monitor and promote better governance of companies.

Holderness and sheeham (1985) and Barclay and Holderness (1991) provide empirical evidence that there are increased management turnovers and stock performance gains following block share purchases. Shome and Singh (1995) also report improved financial performance following block purchases. Bethel et al. (1998) provide further evidence that activist block purchases are followed by corporate restructuring, abnormal share price appreciation, and industry adjusted operating profitability gains.

\subsubsection{Board of directors}

Most corporations are governed by a board of directors. In fact, having a board is one of the legal requirements for incorporation. A board of directors is elected by the shareholders and its job is to hire, fire, compensate, and advise top management on behalf of those shareholders. Fama (1980) notes that the most important role of a board is to scrutinise the highest decision makers in the firm. It is in this light that Mizruchi (1983) pronounces the board of directors to be "the ultimate center of control" in a publicly held organisation. Ingley and van der Walt (2004) point out that the board should be maximising the joint welfare of all stakeholders rather than merely maximising shareholder wealth.

Researchers have emphasised the influence that board size and composition may have on board involvement in corporate affairs. The size and composition of the board may affect its ability to be an effective monitor and guide, they may influence the impact of insiders and block ownership on firm performance by acting as either a complement or substitute for ownership structure.

Board size. With respect to board size, the hypothesis tested has generally been that smaller boards are more effective because they can hold more candid discussions and make decisions more quickly. 
Jensen (1993) and Lipton and Lorsch (1992) suggest that large board can be less effective than small board. The idea is that when boards become too big, agency problems (such as director free-riding) increase with the board and the board becomes more symbolic and less a part of the management process. Yermack (1996) tests this view empirically and finds support for it. He examines the relationship between Tobin's Q and board size on a sample of large US corporations, controlling for other variables that are likely to affect Q. Yermack's results suggest that there is a significant negative relationship between board size and $\mathrm{Q}$.

Confirming the Yermack's finding, Eisenberg et al. (1998) document that a similar pattern holds for a sample of small and midsize Finnish firms. The data therefore appears to reveal a fairly clear picture: board size and firm value are negatively correlated. With a sample of 450 non-financial companies from ten countries in Western Europe and North America, de Andres et al. (2005) find a negative relationship between firm value and the size of the board of directors. Furthermore, Singh and Davidson (2003)'s results indicate that board size is negatively related to asset turnover, but unrelated to discretionary expenditures. This evidence is consistent with the aforementioned notion that large boards fail to be effective monitors. However, Beiner et al. (2004) do not find significant relationship between board size and firm valuation.

Board composition. With respect to board composition, the variable of great interest has been the proportion of independent directors (or outside directors) on the board. Lipton and Lorsch (1992) view an independent director as any director who has no connection with the company, either as management or substantial customers or as supplier of goods or services. The hypothesis is that directors who are members of firm management or who are affiliated with those managers (generally termed inside directors and grey directors, respectively), are less effective as monitors of management than are those outside directors. Fama and Jensen (1983a) argue that independent directors tend to be more effective monitors of management than inside directors because they are generally key decision makers at other organisations who are concerned with their reputations in the managerial-labour market.

According to Fama and Jensen (1983a), independent directors signal their abilities as key decision makers through their board decisions. These non-management directors are believed to provide superior performance benefits to the firm as a result of their 
independence from firm management. Outside directors possess two characteristics that enable them to fulfil their monitoring function. First, their independence (Cadbury, 1992) and second, they are concentrated to maintain their reputation in the external labour market (Fama and Jensen, 1983a). The presence of independent directors represents a means of ensuring that inside directors are pursuing policies consistent with shareholders' interests (Fama, 1980).

An important question concerns the agency conflict-resolving role of independent directors. Fama (1980) and Fama and Jensen (1983b) argue that board outsiders, by providing expert knowledge and monitoring services, add value to firms. Although some empirical studies support that independent directors are more effective monitors and provide a critical disciplining device for managers (Coughlan and Schmidt, 1985; Hermalin and Weisbach, 1988), the evidence relating to their impact on performance tends not to support this positive perspective.

Empirical studies have addressed it using several methods. The first method has been used to examine contemporaneous correlation between accounting measures of performance and the proportion of independent directors on the board. MacAvoy et al. (1983), Hermalin and Weisbach (1991), Mehran (1995), Klein (1998), and Bhagat and Black (2000) all report insignificant relationships between accounting performance measures and the fraction of independent directors on the board. A second approach, suggested by the work of Morck et al. (1988), is to use Tobin's $Q$ as a performance measure, the idea being that it reflects the "value added" of intangible factors such as governance. Heimalin and Weisbach (1991), Yermack (1996), and Bhagat and Black $(2000,2002)$ and Weir et al. (2002) use this approach and find, as with accounting performance measures, that there is no noticeable relationship between the proportion of independent directors and Q. Finally, Bhagat and Black $(2000,2002)$ examine the effect of board composition on long-term stock market and accounting performance. Once again, they do not find any relationship between board composition and firm performance. Overall, there is little to suggest that board composition has any cross-sectional relationship with firm performance.

\subsubsection{Incentive schemes}

When there is a separation of ownership and control, the one taking the potentially valueenhancing actions and the residual claimant of these actions are different persons. Where 
effort is unobservable and/or direct control mechanisms do not function well, incentive schemes are required to induce managers to act in investors' interests. Incentive schemes seek to reduce the degree of the conflicts of interest between principal and agent. If shareholders want the maximum expected financial return on their common stock, then they will benefit from anything that makes management want that same thing, i.e., anything that makes management benefit-financially or otherwise-from an increase in the value of the firm's common stock.

As noted in Antle and Smith (1986) and Jensen and Murphy (1990), executives are given variable compensation and incentive through three primary mechanisms: (1) flow compensation that is the total of the CEO's annual salary, bonus, new equity grants, and other compensation; (2) changes in the value of the CEO's portfolio of stock and options; and (3) the possibility that the market's assessment of the CEO's human capital will decrease of following termination because of poor performance or a change in control. For executives below the CEO, the potential for promotion is an additional source of incentive.

There is presently no theoretical or empirical consensus on how stock options and managerial equity affect firm performance. Studies of this issue generally take one of two perspectives. Studies such as Morck et al. (1988) argue that, on average, observed CEO equity ownership and incentive are "too low." If this were true, most firms would increase firm value by increasing CEO equity ownership. In this setting, CEO executive ownership and firm performance should exhibit a positive association because high- (low) ownership CEOs are closer (further away) from optimal incentive levels.

Morck et al. (1988) find some evidence consistent with this hypothesis, except among CEOs with very large fractional equity ownership. McConnell and Servaes (1990, 1995) find evidence of a positive relationship between increases in ownership and firm performance as long as managerial ownership is less than 50 per cent. Frye (2001) find evidence that firms that provide more equity-based compensation to employees perform better. Short and Keasey (1999) report a non-linear relation between managerial ownership and firm value for a sample of UK firms. Sesil et al. (2000) find mixed evidence that firms using options extensively perform better, and Ittner et al. (2001) find that relationship between option grants and firm performance varies across organisational levels with a 
sample of new-economy firms. A limitation of this research is that the causal direction of the relation between equity incentive and performance is unclear (Kole, 1996).

Rather than higher equity incentives producing better future firm performance, it may be the case that firms expecting better future performance grant more equity (e.g., Yermack, 1997). It would be worthwhile for researchers to analyse this important question using a simultaneous equation or transfer function approach (incorporating leads and lags) to provide evidence on the directionality of the function of linking equity ownership with firm performance. Obviously, one problem with this econometric approach is that it is necessary to specify both the structural and reduced-form equations, along with the selection of appropriate instrumental variables (Himmelberg et al., 1999).

\subsubsection{Audit committees}

The importance of audit committee as both a monitor of and a vital link in the financial reporting process is evidenced by the number of private and public sector advocates ${ }^{11}$ of audit committees, as well as by the four 1988 AICPA expectation gap Statements on Auditing Standards (SASs) that directly acknowledge the importance of audit committees. Audit committees have been heralded as "a large deterrent to the atmosphere that would permit financial fraud to exist" (Treadway Roundtable 1989, p23).

An audit committee is a sub-committee of the main board of directors of a company, usually formed from non-executive directors and charged with matters relating to financial reporting and audit (Spira, 1999). A major responsibility of the audit committee is to oversee the financial reporting process and, according, contribute to the integrity of financial reporting (Wild, 1994a; Lambe, 2005). The introduction of the audit committee into the governance of corporate enterprises coincides with at least three developments that threaten the integrity of managerial accountability: (1) the increased frequency of fraudulent financial reporting - including earning management, computer security breaches, employee thefts, security frauds, and noncompliance with the code of corporate conduct; (2) the expanded complexity of business operations -including growing multinational operations and increased product line diversification; and (3) the heightened litigious environment in which companies operate and effect directors' liability and

\footnotetext{
"See Birkett (1986) for a detailed historical overview of efforts to encourage audit committee formation from 1930 s to the 1960 s.
} 
accountability exposure (Wild, 1994a). ${ }^{12}$

Cadbury Report argues that audit committees are an additional control mechanism that ensures that shareholder interests are being safeguarded. This was achieved by promoting the effective financial management of the company and increasing accountability (Cadbury, 1992). An effective audit committee should bring a number of potential benefits. These include helping the board to meet its statutory and fiduciary responsibilities by improving links between the board and the external and internal auditors. Audit committees should therefore improve the credibility of financial statements, something that benefits shareholders and other users of the information (Collier, 1997). Thus audit committee represents another internal governance mechanism, the impact of which should be to improve the quality of the financial management of the company and hence its performance.

Several empirical studies in accounting have focused on the voluntary formation of audit committees to identify factors affecting the decision to create an audit committee directly responsible for overseeing the financial reporting process (Pincus et al., 1989). Collectively, these studies suggest that larger companies, and which have bigger boards with a greater representation of outside directors, are more likely to voluntarily form an audit committee. Several studies document that the presence of an audit committee is associated with fewer incidences of financial reporting problems. For example, McMullen (1996) finds that entities with more reliable financial reporting, such as those with absence of material errors, irregularities and illegal acts, are significantly more likely to have audit committees. Conversely, Dechow et al. (1996) show that firms subject to the enforcement actions of a government regulator are less likely to have standing audit committees. Carcello and Neal (1999) find the likelihood a company in financial distress will receive a going concern modified auditor's report is lower when the percentage of side or "grey" directors on the audit committee is higher. These findings suggest that the independence of the audit committee may affect the objectivity and independence of the external auditor.

Relatively little evidence has been reported about the impact of audit committee on performance. Vafeas (1999) finds that board subcommittee structure and quality provide insights into those responsible for undertaking the monitoring roles within companies. Wild

\footnotetext{
${ }^{12}$ This characterisation is applicable to the corporate reporting environments in both the USA and UK. Yet, the potential implications associated with audit committee formation on the equity of financial reporting are much broader, and are relevant to corporate environment in other countries.
} 
(1994a) shows that the market reacted more favourably to earnings reports after an audit committee had been established. Klein (1998) reports that neither the presence of an audit committee nor its structure has an effect on a range of accounting and market performance measures. Vafeas and Theodorou (1998) also find no evidence to support the view that the structure of board subcommittees significantly affected performance. Weir et al. (2002) employ UK data to find that audit committee structure has no effect on performance but there is a weak relationship between committee director quality and performance. Cotter and Silvester (2003) are unable to provide evidence that firm value is enhanced through the independence of auditing committee.

\subsubsection{External mechanisms}

\subsubsection{Market for corporate control}

If a company's internal mechanisms fail, the market for corporate control acts as a disciplining mechanism of last resort (Jensen, 1986b). Inappropriate internal mechanisms will manifest themselves in poor performance. This will result in a tender offer being made as other management teams attempt to gain control of the company. This means of disciplining management is especially in use in market-based systems of corporate governance like the US and UK.

In keeping with Berle and Means (1932), the theory of the market for corporate control was suggested by Manne (1965) and then refined in a series of articles by Jensen and Meckling (1976), Fama (1980), and Fama and Jensen (1983a, b). According to this theory, as top managers engage in self-interested behaviour, their company's performance is likely to increasingly diverge from its maximum potential. This underperformance is reflected in the value of the company's stock. Under such circumstances, other management teams are likely to offer themselves to the shareholders as alternatives to the incumbent management. The market for corporate control, then, is the competition among these management teams for the rights to manage corporate resources. As Lowenstein (1983) noted, the acquiring company's expected gain resides almost entirely in the expectation that it will be able to root out deadwood inefficiencies and put a target's assets to better use.

The market for corporate control can operate in three ways: proxy contests, friendly 
mergers and hostile takeover (Bai et al., 2002). Proxy fights do not usually unseat the existing board of directors successfully because shareholdings are often spread among many shareholders. Friendly mergers and takeovers occur in all countries and account for most of the transaction volume that occur. For hostile takeovers, they do occur fairly frequently in the US and UK, however, much less in Germany and Japan.

Evidence on hostile takeovers is positive. Target shareholders earn, on average, positive returns from tender offer. Jarrell and Poulsen (1987) estimate premia for 663 successful tender offers in the US to average 19 per cent in the 1960s, 35 per cent in the 1970s, and 39 per cent in the 1980s. Many other studies confirm these figures or report even higher target shareholder gains from takeovers (see Jensen and Ruback, 1983; Jarrel et al., 1988 for surveys; see also DeAngelo et al., 1984 or Franks and Mayer, 1998).

There are higher announcement period returns and higher post-takeover returns in tenders than in mergers (see Servaes, 1991; Agrawal et al., 1992). There is considerable agreement that target shareholders are among the winners of takeover contests, particularly when the bids are hostile. However, bidder shareholders' abnormal returns are on average close to zero. Some studies find small gains, other small losses. Higson and Elliott (1998) find essentially zero abnormal returns for bidders in the UK. Moreover, in 11 out of 16 years under study, average returns to bidder shareholders over 24 months were negative.

For mergers, the verdict is even more negative. The majority of studies does not find significant improvements of firm performance following a merge, or find even a negative development. Ravenscraft and Scherer (1987) report substantial deterioration of profitability of business acquired in mergers. Mueller and Sirower (1998) reject synergistic gains for 168 US mergers during the period 1978-1990.

In conclusion, ex post studies indicate that acquirers improve only moderately firm efficiency after a merger/takeover. Results are mostly negative for unrelated and conglomerate mergers, and ambiguities remain with hostile takeovers.

\subsubsection{Legal and regulatory systems}

The most basic corporate governance mechanisms existing outside firms are the system of 
laws and regulations that govern the firm. Recent research on corporate governance around the world has established a number of empirical regularities. Such diverse elements of countries' financial systems as the breadth and depth of their capital markets, the pace of new security issues, corporate ownership structures, dividend policies, and the efficiency of investment allocation appear to be explained both conceptually and empirically by how well the laws in these countries protect outside investors. Investor protection turns out to be crucial because, in many countries, expropriation of minority shareholders and creditors by the controlling shareholders is extensive. When outside investors finance firms, they face a risk, and sometimes near certainty, that the returns on their investment will never materialise because the controlling shareholders or managers expropriate them. To a large extent, corporate governance is a set of mechanisms through which outside investors protect themselves against the expropriation by the insiders.

A rapidly growing law and finance literature has established that the legal environment, and more specially the extent of investor protection, can affect the quality of corporate governance. La Porta et al. $(1998,2004)$ demonstrate that in terms of both the applicable laws and the degree of enforcement of those laws, US shareholders (and creditors) are among the most protected in the world. La Porta et al. (2000) find that cross-country differences in ownership structure, capital markets, financing, and dividend policies are all related to the degree to which investors are legally protected from expropriation by managers and controlling shareholders. They document an inverse relationship between the degree of such protection in a country and the degree of ownership concentration in firms in that country.

Shleifer and Vishny (1997) argue that in the large corporations of many countries, the fundamental agency problem is not that between managers and shareholders because control-and the private benefits that accompany control-rests primarily with large shareholders. In such countries, the more relevant conflict of interest is that between outside investors and controlling shareholders. Liu (2005) states that law and the development of a good legal system can shape how corporations can be controlled for the best interests of the firm and its owners, because law defines the responsibilities of the parties and ensures enforcement. Thus, a country's legal system appears to be a fundamental determinant of how its corporate governance structure evolves. 
Although the ultimate benefit of legal investor protection for financial development has now been well documented, the effect of protection on valuation has received less attention. La Porta et al. (1999a, 1999b, 2002) evaluate the influence on corporate valuation of investor protection and ownership by the controlling shareholder using company data from 27 of the wealthiest economies around the world. They find that companies in common law countries have higher valuations than do companies in civil law countries, and better shareholder protection is associated with higher corporate valuation. Interestingly, they find that cross-country differences in equity valuation, the cost of capital, and the magnitude of external financing are explained by a country's legal origin. Obviously, legal infrastructure is an effective external mechanism to ensure that investors get a fair return on their investment.

\subsubsection{Managerial labour market}

Fama (1980) stresses the importance of the managerial labour market. He argues that the outside managerial labour market exerts many direct pressures on the firm to sort and compensate managers according to performance. One form of pressure comes from the fact that an ongoing firm is always in the market for new managers. Potential new managers are concerned with the mechanics by which their performance will be judged, and they seek information about the responsiveness of the system in rewarding performance. Moreover, given a competitive managerial labour market, when the firm's reward system is not responsive to performance the firm loses managers, and the best are the first to leave.

Jensen and Ruback (1983) see the market for corporate control as a market in which alternative teams compete for the rights to manage corporate resources. Hence, they perceive the takeover market to be an important component of the managerial labour market. When the incumbent management team does not perform satisfactorily, its position is threatened by a takeover and subsequent replacement by another management team.

\subsubsection{External auditing}

'Without audit, no accountability; without accountability, no control; and if there is no control, where is the seat of power?' (Normanton, 1966, p7). 
This well-known quotation crystallises the idea that audit is necessary, independent attestation of the accountability to the stakeholders by the board of directors.

The objective and contribution of external auditing is to strengthen the corporate accountability. The main responsibility of external auditor is to detect and correct manager's bias or negligence in the presentation of financial statements. Therefore, the independence and integrity of the auditors must be maintained if the corporation is to operate efficiently in the modern business world. Stamp and Moonitz (1978) stress the significance of the role of external auditors. They argue that an essential component of the credibility of financial reporting is provided by the favourable opinion from an auditor, no matter how competent a company's financial accountants may be, no matter how high the accounting standards that have been established, and no matter how informative the financial reports of the company are, and the strength of capital markets, and indeed, of the economic system, depend heavily on the general confidence engendered by the credibility that attaches to a set of audited financial statements.

Controlling owners could mitigate minority shareholders' concern of being expropriated by employing high quality external auditors to endorse financial statements (Claessens and Fan, 2002). Fan and Wong (2002) use a broad sample of firms from eight Asian economies to demonstrate that firms are more likely to employ Big Five auditors when they are subject to agency problems imbedded in their ownership structure. Among Asian firms subject to agency problems, Big Five auditors charge a higher fee and set a lower audit modification threshold, while other auditors do not. Taken together, their evidence suggests that Big Five auditors in Asia do have a corporate governance role.

\subsection{Corporate governance in emerging economies}

Emerging economies are assuming an increasingly prominent position in the world economy. Of the 64 emerging economies identified by Hoskisson et al. (2000), 51 are rapidly growing developing countries and 13 are in transition from centrally planned economies (often called 'transition economies') (Wright et al., 2005). Transition economies may be categorised as the countries of Central Europe, Southeastern Europe and the Baltics (CSB); the Commonwealth of Independent States (CIS); and a group of Asian countries, including the People's Republic of China (PRC) (Day and Taylor, 2004). Clearly, transition 
economies are numerous and vary widely in their level of economics and social development, political, economic, and social stability, commitment to transition, and position in the transition cycle.

Research has shown that the institutional structures in emerging economies differ significantly from those familiar in the West (Hoskisson et al., 2000; Peng, 2000, 2003). Some theorists have argued that institutional theory is the most applicable paradigm for explaining enterprise behaviour in emerging economies (Shenkar and von Glinow, 1994; Hoskisson et al., 2000; Judge et al., 2003). However, the agency theory still has played a major role in transition economies (Peng, 2000, 2004; Young et al., 2002). Agency problems associated with the separation of ownership and control are central to transition economies. Indeed, recent research suggests that there is not only a principal-agent problem in transition economies, but also principal-principal (e.g., majority-minority shareholder) problems (Young et al., 2002; Bai et al., 2004). In addition to traditional agency problem, the weak governance context of emerging economies creates a unique set of agency conflicts relating to expropriation of minority shareholders (Cho, 1999). Expropriation occurs within the weak governance context when large or majority shareholders assume control of the firm and deprive minority shareholders the right to appropriate returns on their investment (Shleifer and Vishny, 1988).

Claessens et al. (1999) argue that the potential problems attendant with the separation of ownership and control in the emerging market corporate form give way to those associated with the combination of ownership and control. This has led to serious problems associated with the oppression of minority shareholder rights by controlling shareholder managers through multi-tiered share structures, and related partly transactions in opaque semi-private or family-based conglomerates. The emerging market companies are frequently closely held, often by the founding family, do a relatively poor job of enforcing shareholders' legal rights, and need to improve their accounting and transparency (Coombes and Watson, 2001). These characteristics are often thought to be associated with poor corporate governance.

World Bank (2002) states that institutional inadequacies in Eastern Europe and the former Soviet Union, which contribute to the agency costs associated with insider ownership and control, include a lack of rules to protect minority shareholders, lack of rules controlling 
insider dealing and conflicts of interest, inadequate rules on takeovers, insolvency and collateral, and poor accounting disclosure and auditing regulations.

Reviewing the literature on corporate governance issues in Asia, Claessens and Fan (2002) confirm that limited protection of minority rights in Asia allows controlling shareholders to expropriate minority shareholders, and the agency problems have been exacerbated by low corporate transparency, associated with rent-seeking and relationship-based transactions, extensive group structures and diversification, and risky financial structures.

A few studies have examined the corporate governance mechanisms in emerging economies. Researchers have studied the implications of the concentrated corporate ownership that is common in many emerging markets. In Asia, corporations tend to follow the "insider" model, with the dominant control held by the original owners and large shareholders (Sycip, 1998; Yamazawa, 1998). The quintessential Coasian (1937) form of the firm is the exception rather than the rule in Asia. Instead, the family-based conglomerate is predominant in South East Asia, network-based conglomerate in Japan and Korea, and state-owned enterprises in China, and Singapore in which the corporation often contributes to, rather than attenuates, market failure in the classical sense (Wong, 1985; Berglof and Perotti, 1994; Zhuang, 1999). Relative to the United States and many other developed economies, La Porta et al. (1999a), Claessens et al. (2000), and Lins (2003) show that widespread use of pyramidal ownership structures and cross-holdings in East Asia allows insiders to exercise effective control over a company, despite owning relatively few of its cash flow rights. Moreover, La Porta et al. (1998) argue that absence of strong legal protections and other economies further increases the severity of agency problems between controlling insiders and outside investors.

La Porta et al. (1999a) study 27 countries and conclude that the principle agency problem in large corporations around the world is the expropriation of minority shareholders by the controlling shareholders. Claessens et al. (2000) identify the ownership structure of the firms in nine East Asian countries and conclude that the main corporate governance problem in these countries is also the expropriation of minority shareholders by controlling shareholders. Lins (2003) investigates the relation between ownership structure and firm value across 1433 firms from 18 emerging markets and finds that when a management group's control rights exceed its cash flow, the firm values are lower. Lin also finds that 
large non-management block-holdings are positively related to firm value. Both of these effects are significantly more pronounced in countries with low shareholder protection. The authors of three papers carefully trace through pyramidal shareholding structure to identify a firm's ultimate owners.

Gibson (2003) tests whether corporate governance is ineffective in emerging market by estimating the link between CEO turnover and firm performance for over 1,200 firms in eight emerging markets. Such a link is a necessary, though not a sufficient, condition for effective corporate governance. He finds two main results. First, CEO of emerging market firms are more likely to lose their jobs when their firm's performance is poor, suggesting that corporate governance is not effective in emerging markets. Second, for the subset of firms with a large domestic shareholder, there is no link between CEO turnover and firm performance. For this subset of emerging market firms, corporate governance appears to be ineffective. Dockery and Herbert (2000) argue that there is almost absence of market for corporate control in transition economies.

Focusing on the four significant transition economies from the Central Europe, Day and Taylor (2004) argue that during an interim stage whilst equity markets are weak or nonexistent, debt finance has a useful role to play. However for this to be possible, there are some important institutional changes that are necessary in order to provide the infrastructure, within which debt finance can operate effectively and efficiently.

Claessens and Djankov (1999a, 1999b) study corporate governance in Czech Republic. Using data on recently privatised firms, they find that firms with concentrated ownership, foreign ownership, and ownership by non-bank investment funds are more profitable and have higher labour productivity. They also find that CEO turnover is followed by improvement in profitability and labour profitability. These effects are stronger when the new CEO is appointed by a private owner, rather than the government. Sucher and Zelenka (1998) review the development of the role of audit in Czech Republic. Using a considerable amount of data, Hanousek and Kocenda (2003) conclude that large-scale privatisation improve corporate governance in Czech Republic.

Sarkar and Sarkar (2000), Khanna and Palepu (1999), Chhibber and Majumdar (1999), and Kumar (2003) study corporate governance in India. Khanna and Palepu, and Sarkar and 
Sarhar examine how the identity of the immediate owners of Indian firms is correlated with the firms' valuation. Chhibber and Majumdar examine how ownership characteristics of Indian firms affect profitability. A common result across the three Indian papers is that high foreign ownership has beneficial effects either on market valuation or on profitability. Kumar examines empirically the effects of ownership on the firm performance for a large sample, and does not find any evidence that the difference in ownership structure affect firm performance after controlling for observed firm characteristics and firm fixed effects.

Judge et al. (2003), Peng et al. (2003), and McCarthy and Puffer (2003) research the corporate governance in Russia. Using the agency and institutional perspectives, Judge et al. examine board structure-- firm structure relationship within Russia. They find a negative relationship between "informal" CEO duality and firm performance, a negative relationship between proportion of inside directors and firm performance as well. In this respect, these findings suggest that effective corporate governance may be essential to firm performance in Russia. Based on a survey of 314 privatised firms, Peng et al. test whether outside board members and new managers are positively related to firm performance. However, the evidence offers little support for the hypotheses. McCarthy and Puffer provide an integrative framework for analysing corporate governance in Russia. With large companies as the focus, the framework is particularly appropriate for companies in transitioning economies whose corporate governance are still developing. The framework draws on a cultural-embeddedness model as well as agency and stakeholder theories.

\subsection{Summary}

Corporate governance systems in different countries of the world can be roughly divided up into two categories, market-based and bank-based systems. Each system has its respective strengths and weaknesses, and a kind of convergence appears to occur.

To resolve the agency conflicts, various corporate governance mechanisms are introduced, such as ownership structure, board of directors, incentive schemes, audit committees, market for corporate control, legal and regulatory systems, managerial labour market, external auditing. Empirical studies about the relationships between these mechanisms and firm performance have yielded conflicting results. 
Corporate governance in transition economies appears to be ineffective, and the central agency problem is the expropriation of minority shareholders by controlling shareholders.

With the increased attention on corporate governance worldwide, the active role of institutional shareholders in monitoring and controlling management is becoming important. The next chapter reviews the literature about the role of financial institutions in corporate governance. 


\section{Chapter Four \\ Literature Review Part II \\ The Role of Financial Institutions in Corporate Governance \\ outside China}

\subsection{Introduction}

The previous chapter sketches the market-based and bank-based corporate governance systems and discusses the effectiveness of various governance mechanisms outside China. As the purpose of modern corporate governance is to increase shareholders and economic wealth in a sustainable way (Healy, 2003), great attention has been paid to corporate governance almost all over the world since the 1990s. Each country has made various efforts to enhance the efficiency and effectiveness of corporate governance and, consequently, to increase the value of its companies. Along with the increased attention on corporate governance, the active role of institutional shareholders in monitoring and controlling of management is becoming of great importance (Choi and Cho, 2003).

In the UK, US and other developed countries, the role of financial institutions as monitors of corporate management has been emphasised in their corporate governance reports. For example, in the UK, Cadbury (1992) says to 'look to the institutions in particular... to use their influence as owners to ensure that companies in which they have invested comply with the Code'. In Greenbury (1995), 'the investor institutions should use their power and influence to ensure the implementation of best practice as set out in the Code'. In Hampel (1998), 'it is clear...that a discussion of the role of shareholders in corporate governance will mainly concern the institutions'. In the US, Useem (1996) states that the concentration of shares, and hence power, into a relatively small number of hands, has enabled financial institutions to directly challenge management on issues of concern. In Australia, Bosch (1993) points out that institutional shareholders, because of their increasing influence, by virtue of their size, should take an active interest in the governance of the company and develop their own principles of good practice.

The Financial Economists Roundtable (1998) also encourages institutional owners to take a 
proactive role in corporate governance by means of (1) thoughtfully and responsibly voting their shares, (2) communicating with management, the press, and, to the extent allowed by the law, other shareholders, and (3) introducing proxy resolutions.

Hence, the purpose of this chapter is to provide an understanding of the role of financial institutions in corporate governance outside China. As a result, this chapter provides a theoretical background and a point of contrast with the role of financial institutions in corporate governance in China. Section 2 depicts financial institutions around the world. Section 3 presents an overview of the role of financial institutions in corporate governance. Section 4 provides the process of institutional participation in corporate governance. Section 5 discusses the factors that affect the role of financial institutions in corporate governance. Section 6 discusses the relationship between institutional ownership and firm performance. Finally, this chapter ends with a summary.

\subsection{Financial institutions around the world}

As Black (1992b) states that the single phrase "financial institutions" obscures important differences between individual types of financial institutions, different categories of financial institutions have different regulations governing their activities, and have different customer objectives to satisfy (Monks and Minow, 1995). In a similar vein, Wharton (1995) asserts that investors are not monolithic, and the label "financial institution" covers a wide spectrum, being extremely varied in both their interests and approaches to issues.

Financial institutions primarily include pension plans, mutual funds, insurance companies, and banks (Sherman et al., 1998; the Financial Economists Roundtable, 1998; Ryan and Schneider, 2003). Before analysing their governance role, I briefly review the distinct types of financial institutions, each with different potential effects on corporate governance (Ryan and Schneider, 2002).

\subsubsection{Pension plans}

Pension plans are financial institutions with a legal obligation to provide retirement income to participants (Kidwell et al., 1993). In the US, pension funds are regulated by the Labour Department's Pension and Welfare Benefits Administration. To strengthen their influence over corporate management, public and private pension funds formed the Council of 
Institutional Investors (CII) in 1985. Several players must be distinguished in the area of pension fund management (Conrad, 1988). The fund sponsor is the employer who creates and administers the retirement fund, and the fund manager, usually an employee of the fund sponsor, is the person who bears primary responsibilities for overseeing the fund. The portfolio manager, often external to the firm, actually buys and sells securities and sometimes has proxy voting authority.

Public pension plans. Public pension funds are the retirement plans of public sector employees. Because no federal-level regulations govern them, state plans face varying legal environment (Woods, 1996). They tend to be passively managed (Brancato, 1995), and, reflecting their civil-service environment (O'Barr and Conley, 1992), they remain largely defined benefits. Public funds, including the California Public Employees' Retirement System (CalPERS), have been more active in pressing for governance and performance improvements than have other types of financial institutions (Useem, 1996), and they are more likely than many others to focus on social issues (Romano, 1993). Public plan managers may also face political pressures to invest in local communities (Romano, 1993).

Private pension plans. Private pension plans are the retirement vehicles of private sector employees. The Employee Retirement Income Security Act (ERISA) of 1974 was intended to regulate these traditionally define-benefit plans (Brancato, 1997), but its exclusion of corporate liability for defined-contribution losses may have contributed to private funds' recent shift toward more defined-contribution and hybrid plans (Bodie and Crane, 1999). Private fund managers tend toward a lack of involvement in corporate governance (Useem et al., 1993), perhaps because of a norm of "mutual forbearance," and they avoid voting against other firms' management for fear of retaliation (Brown, 1998). Funds that do business with their portfolio firms may also forgo activism because of "pressure sensitivity," or a conflict of interest caused by their dual roles as investor and supplier (Brickley et al., 1988). Their strict regulatory environment, including ERISA, may further discourage activism among private defined-benefit plans (Blair, 1995; David and Kochhar, 1996).

Private multiemployer plans. A subset of private pension plans, multiemployer plans are generally administered by their members' labour unions across groups of sponsors. Some are aggressive activists (O'Connor, 1999), publicising executive compensation levels, 
targeting under performing companies, and casting their votes against management positions (Schwab and Thomas, 1998). TIAA-CREF, the largest fund in the United States (Pellet, 1998), is a multiemployer system for academics. Its defined-contribution plans are invested with a primarily financial agenda, but they extend to social goals on behalf of members who invest in their social fund (TIAA-CREF, 2002). TIAA-CREF has demonstrated a pattern of pressing for corporate governance improvements through such means as proxy voting, shareholder resolution sponsorship, and quiet diplomacy (Carleton et al., 1998; Byrne, 1999).

\subsubsection{Mutual funds}

The mutual fund industry is highly competitive, characterised by many funds, great rivalry, and much public information regarding fund performance (Fredman and Wiles, 1998). Mutual funds are open-ended investment companies that issue shares in diversified portfolios (Radcliffe, 1990). Managers of mutual funds have different behaviour since they are designed for liquidity (Johnson, 1993). Investors are entitled to redeem their shares and receive their money at any time at the prevailing market price. The performance of mutual fund managers is often evaluated on a quarterly basis, which may also promote tendencies toward short-term thinking and passivity toward portfolio firms. Yet, mutual fund managers are moderately activist (Useem, 1993), particularly managers of socially screened mutual funds, who exhibit greater activism regarding their causes (Roosevelt, 2000).

\subsubsection{Insurance companies}

Insurance companies are governed by state laws, consist of life/health and property/casualty companies, and function as risk bearers in the insurance process. Insurance companies have received little attention as financial institutions because of their low profile and relatively small aggregate size. Insurance company fund managers usually have a very strong vested interest in the firms in which they invest (Kochar and David, 1996). Insurance companies tend to invest with their own insurance funds primarily in bonds and mortgages; therefore, they may view their limited equity holdings with a shortterm horizon, discouraging them from intervening with portfolio firms (Eng, 1999). In addition, they try to develop other commercial business with the firm, such as providing insurance or pension products, which may encourage sale over activism, and derive much of their business from corporations, which may make them "pressure sensitive" to the 
potential loss of business risked by engaging in activism with firms who also customers (Brickley et al., 1988).

\subsubsection{Banks}

As banks have not traditionally been allowed to own equities other than through their trust function, they account for a small percentage of equity holdings. Their relative lack of equity investment is largely due to Depression era and more modern regulation, including the Glass-Steagall Act, which has historically barred nationally and state-chartered Federal Reserve member banks from holding equity for their own accounts (Barth et al., 2000). However, this proportion may change with the repeal of the Glass-Steagall Act (Kirsch, 1997; Kuttner, 1999).

Banks can have current or future relationships with firms that may create conflicts of interest with their fiduciary obligations (Brickley et al., 1988), therefore, they are likely to support the decision of management. Black (1992b) argues that banks may vote in support of top management even if the consequence is a reduction in firm market value. Although banks' conservative interpretation of fiduciary responsibility (Del Guercio, 1996) may also lead to passivity, they may be more active than insurance companies (Brancato, 1997).

\subsection{An overview of the role of financial institutions in corporate governance}

Institutional ownership of equities has grown rapidly in recent years, at the same time, the market for corporate control that was active in the 1970s and 1980s, and that served effectively to discipline managers, has weakened substantially (Jensen, 1989). The rise in the institutional shareholdings and corresponding decline of market for corporate control have focused attention on the role and importance of financial institutions as monitors of corporate management. The increase in monitoring by traditionally passive financial institutions has been described as "shareholder activism" (Smith, 1996). Financial institutions engage in corporate governance activities mainly through either submitting proposals or privately negotiating with management of targeted firms, with the stated goal of improving firm performance (Romano, 2001). 


\subsubsection{Competing views about shareholder activism and its impact on targets}

A central tenet of shareholder activism holds that shareholder activism increases firm value by ameliorating the shareholder-manager agency conflict and pressuring managers to adopt value-increasing policies. Ryan (1988), Gordon (1993), and Pozen (1994), for example, argue that shareholder activism can encourage managers to make specified value-enhancing changes. Others, including Black (1992a) and Pound (1992a), point out that shareholder initiatives, presumably including corporate governance proposals, offer a way to influence corporate policy with less rancor and fewer costs than are typically associated with takeover bids and proxy contests. Supporting these views is evidence that some forms of shareholder activism are associated with firm value increases. Wahal (1996), for example, documents that the earliest announcements regarding such pressure are associated with positive average abnormal returns to the targets' stock. Similarly, Strickland et al. (1996) find a positive average stock price reaction for 53 negotiated agreements between targeted firms and United Shareholders Association representatives.

Some other studies also examine the effect of institutions' private negotiation strategies and find significant positive stock price effects. Carleton et al. (1998) examine the impact of the corporate governance activities of TIAA-CREF, which seeks to negotiate privately with firms it has targeted and typically reaches an agreement with management that results in its not having to submit a proposal. They find no significant changes in accounting measures of long-term performance from TIAA-CREF's activism, but the stock price effect of the initial targeting is significant, depending on the substantive content of the negotiations. Another positive finding concerning "behind the scenes" activism involves a study by Strickland et al. (1996) of the firms targeted by USA. When management agreed to USA's requested changes prior to the proxy proposal submission deadline, the targeted firms experienced positive stock price effects in contrast to the insignificant effect when USA presented a proxy proposal. The negotiated agreements involved takeover defenses, board composition, and confidential voting. Contrary to the TIAA-CREF study, there was no difference in the sign and significance of the price effects across USA's three types of proposals. Opler and Sokobin (1997) examine the returns of firms on the Council of Institutional Investors' (CII) "focus-list" of poor performance. They find that the targeted firms experience better market and operating performance than market as a whole and other benchmark portfolio in the year subsequent to their inclusion on the CII list. They infer from this result that coordinated investor action that takes place behind the scenes is 
effective in improving firm performance, in contrast to the proxy proposal route, which often involves campaigns by one investor, and for which studies do not find positive effects.

Holland (1995, 1998, and 1999), Holland and Doran (1998) explore the corporate governance role of financial institutions in portfolio companies through case study interview with senior directors and fund managers in UK-based financial institutions. These cases revealed a long term, private, programmed set of regular interactions between financial institutions and companies, in which implicit financial institution 'relationship' influence was exercised and a two-way flow of information (i.e., information collection and knowledge acquisition) occurred. This implicit influence process was constrained by financial institutions' unwillingness to interfere in good performing companies and by their limited power in co-operative circumstances. These financial institutions were able to use their quasi insider knowledge advantage to diagnose problem areas in strategy, management quality, and the effectiveness of the board; and they kept that diagnosis in reserve until circumstances arose where they could exercise much strong influences. Much of the process of influence and intervention was conducted outside of the public gaze, i.e., "behind the scenes," while occasionally, financial institutions applied public pressure via the media, or sold their shares in the company. The most important factor in deciding the appropriate method of intervention was long-term decisions on the financial institutions' long portfolio investment policy.

A competing view holds that shareholder activism tends to impair firm management, degrade performance, and decrease firm value. Two specific criticisms are made of pension fund managers who attempt to interfere with corporate management. First, institutional activists have neither the skills nor the experience to improve on managers' decisions (Wohlstetter, 1993). Activists' attempts to influence corporate decisions therefore tend to disrupt the firm's operations. Lipton and Rosenblum (1991) argue that even wellintentioned initiatives can distract managers and harm their abilities to manage effectively. Second, they myopically focus on short-term earnings to the detriment of the firm's longterm financial health. Graves (1988) argues that fund managers cannot afford to take the long view in their investment decisions since they are reviewed and rewarded on the basis of quarterly, or at most, annual performance measures. Drucker (1986) points out that defined benefit pension plans are often compelled by employers to liquidate the plan's stock holdings and realise short term gains. 
Another reason activists may interfere with a target firm operation is that they pursue goals other than share value maximisation. There is a growing literature that finds indirect evidence that activist funds are politically motivated. Based on a sample of Fortune 500 firms, Woidtke (1996) reports a negative relation between firm performance (industryadjusted Tobin's Q) and percentage of ownership by activism public pension funds. Wagster and Prevost (1996) find that firms targeted by CalPERS have significantly negative stock price reactions to the announcement of the 1992 proxy rule changes. The study of Johnson et al. (1997) shows that a dummy variable for CalPERS 1992 'hit-list' firms is negatively related to both CEO compensation changes and pay-for-performance sensitivity changes, which they interpret as evidence that CalPERS acts more like a populist crusader against executive pay levels than a wealth-maximising shareholder. Similarly, Faccio and Lasfer (2000) find that value added by occupational pension funds is negligible and their holdings do not lead companies to outperform their industry counterparts after comparing companies in which pension funds hold large stakes.

These results are also consistent with the arguments of Murphy and Van Nuys (1994) and Romano (1993) that pension funds are not effective monitors because of the agency problems within the funds themselves. They argue that managers of public funds may use their influence to further their political or personal goals, instead of maximising beneficiary wealth. For example, Murphy and Van Nuys predict that public pensions will tend to target high-profile companies, generating large non-monetary rewards for fund managers in the form of publicity (that in turn may affect their future employment opportunities). Others assert that the investors with superior incentive structure, is the evidence that public funds have ulterior motives. There are, however, reasonable alternative explanations for these observations. As Guercio and Hawkins (1999) point out, the use of publicity might be part of an overall strategy for an index fund to maximise value. Further, other types of institutions, such as corporate pension funds, bank trusts, and insurance companies, might forgo activism because they are reluctant to appear openly antagonistic to management or jeopardise business relationship with the firm. Anecdotally, in 1987, CEOs of seven Fortune 500 companies wrote letters to their fellow CEOs urging them to instruct their pension managers to vote against shareholder proposals (Institutional Investor, June 1988, p162). In addition, Pound (1988) reports that pressure-sensitive institutions such as banks and insurance companies are more likely to side with management in a proxy contest, possibly in order to ensure further business ties with firm. Similarly, Van Nuys (1993), in a 
case study of a proxy fight at Honeywell Corporation, finds that bank trusts and insurance companies are more likely to support management sponsored anti-takeover proposals than are public pension funds.

A third view is that shareholder activism has negligible effects on target companies' policies, operations, and values. This view is reflected in Jensen's (1993) observation that internal control systems, which include shareholder-initiated proposals, of publicly held corporations often fail to make managers maximise value. Romano (1998) explains that this is because most activist efforts seek governance changes that have little potential to change the target firms' operations. It is also suggested by evidence that some shareholder proposals seek to repeal corporate charter provisions that have negligible valuation effects in the first place. DeAngelo and Rice (1983) and Linn and McConnell (1983), for example, report that upon announcement of such charter amendments as supermajority voting rules and classified boards, the average abnormal returns are insignificantly different from zero. In particular, the study of Wahal (1996) shows little evidence that operating performance of companies that are targets of pension funds proposals improves, and Gillan and Starks (2000) similarly document no significant stock price reaction to proxy proposals offered by financial institutions.

In addition to examining the impact of activism on performance, some studies investigate whether portfolio firms engage in corporate restructurings or other governance reforms after they have been targeted by financial institutions. The rationale is that the undertaking of significant structural changes by firms after a proxy targeting is an alternative means by which to gauge the success of shareholder activism. The assumption is that such changes will eventually improve performance.

There is considerable divergence across studies concerning whether targeted firms make significant structural changes, such as firing the CEO or selling substantial assets. The difference would appear to be related to the studies' variation in findings concerning stock price performance. Karpoff et al. (1996), who find no stock price effects, find little evidence of policy changes in direct response to a proxy vote, and, in particular, that CEO turnover is not related to receipt of a shareholder proposal. The studies finding subsample positive stock price effects, however, tend to find an increase in the level of asset divestitures of the targeted firm. For instance, Smith (1996) reports no significant 
difference in CEO turnover in targeted firms compared to industry and performance control groups, but significantly higher sales of assets by the targeted firms. In addition, the study of Opler and Sokobin (1997) shows a decrease in CEO turnover but an increase in asset sales after activism targeting.

The fit is less exact with the results in Guercio and Hawkins (1999). They find significantly more newspaper reports of restructuring activity and increased employee, but not increased $\mathrm{CEO}$, turnover in targeted firms, compared to an industry and performance control group as well as for various subsamples, and increased CEO and employee turnover for board proposal subsample, but neither the full sample nor the subsamples experiencing significant restructuring activity had significant positive returns. Huson (1997) also documents that CalPERS targets engage in more asset divestures than a set of control firms over three years subsequent to the targeting, although the control group is quite imprecise (the control firms are either smaller or better performers that CalPERS targets); he does not, however, investigate the price effects of the targeting.

The above competing views are based on the role of financial institutions in the US and UK, however, empirical evidence on the roles of financial institutions outside the US and UK is sparse. Sarkar and Sarkar (2000) examine the role of large shareholders in corporate performance in India. They find no evidence that financial institutions, typically mutual funds, are active in governance. Chio and Cho (2003) fail to find evidence that shareholder activism in Korea appears to have effects on the financial performance and shareholders' wealth of its target companies.

\subsubsection{The influence of legal environment}

Legal rules can affect the institutions' choice between holding debt and equity, the size of the stakes that the institutions own, and what they can do with those stakes (Black and Coffee, 1994). Verstegen and Marguerite (2002) also suggest that a mix of financial, legal, and social influence has shaped financial institution activism and affects different financial institutions to different degrees. One of the main reasons for the increasingly active role of financial institutions is that changes in proxy rules have made communications and coordination among shareholders easier, thereby lowering the cost of the effective monitoring (N.Y. Times, 1993). 
The legal system within a country further influences the role of institutional shareholders (Gillan and Starks, 2003). For example, an institution's ability to monitor the firm by means of voting might be limited by certain features of the legal and regulatory environments. In some European countries, the voting system entails "share blocking," which requires shareholders wishing to vote to hold their shares and show up at the annual meeting (in contrast, in the US, those who hold shares as of the date of record are permitted to vote at the annual meeting.) This highlights the potential tradeoff between liquidity and control, as "blocking" the shares effectively prohibits the investor from trading prior to the annual general meeting. Share blocking likely continues to low voting turnout at some companies.

The case of the French company Vivendi Universal is another illustration of how governance structures and the legal environment affect shareholders' rights and ability to vote. At the 2000 annual meeting, Vivendi shareholders approved a resolution curbing voting rights. The resolution permitted the company to scale back the voting power of blocks above 2 per cent, contingent on the level of voting turnout. Given the company's historical 30 per cent voting turnout, it was argued that the resolution would prevent blockholders from applying a disproportionate influence on the company. Investors, both in France and internationally, condemned the action. Not only do such voting caps limit shareholder voting rights, they also have the potential to entrench management and exacerbate agency problems.

In Korea, laws in place prior to 1998 prevented financial institutions from voting their shares. According to Joh (2003), although financial institutions owned 40 per cent of the publicly traded companies' shares, there existed a "shadow voting" rule that prevented financial institutions from voting those shares. Rather, votes by financial institutions (that in aggregate owned about 20 per cent of the shares) were cast in the same proportions as votes by the non-financial institutional shareholders.

A report of the Standing Senate Committee (1998) indicates that in Canada, mainly four legal restrains are identified as barriers inhibiting financial institutions from being active as they might otherwise be in corporate governance issue. One of the restrains is the absence of a confidential voting system for shareholders, and confidential voting may well have the potential to increase the level of shareholder activity in corporate governance issues. Legal 
restrains on communications amongst shareholders act as impediment to shareholder activism. The 10 per cent of takeover bid threshold is the third legal constraint in Canada. Another potential constraint on shareholder activism is the difficulty in identifying a corporation's shareholders that stems from the modern share trading system, in which shares are held by nominees, including securities depositories.

More generally, different legal and financial systems in countries have led to different corporate governance system worldwide. For example, La Porta et al. (1997) argue that investor protection and corporate governance are stronger where the legal system is based on common law as opposed to civil law. Roe (1990) contends that in the early part of the twenties century, institutions in the US were active in corporate governance, but the federal government curtailed their participation. To be sure, the roles of financial institutions worldwide differ due to differences in various countries' stages of development and laws that govern their behaviour (Gillan and Starks, 2003). It has been suggested that laws affecting the role of financial institutions are the major reason for evolutionary differences between corporate governance systems in the US and those in other countries, such as Germany or Japan.

\subsection{Process of institutional participation in corporate governance}

\subsubsection{The supply and demand of institutional participation in corporate governance}

Financial institutions have the incentives, the power, and the methods to participate in corporate governance.

As financial intermediaries, financial institutions bear fiduciary responsibilities, which obligate them to closely monitor their holdings and take action to protect investments against erosion in value. While there are variations in the regulations affecting different types of institutions, all institutions are subject to a 'prudent person' rule, under which they have a duty to their beneficiaries to exercise such care and skill as a man of ordinary prudence would exercise in dealing with his own property (Krikorian, 1991).

The fiduciary responsibility requires an active role by financial institutions in the full exercise of their shareholder rights, and failure to do so constitutes a breath of their obligations. Financial institutions are held liable for losses arising from lack of prudence in 
their investments. The US Department of Labour has issued several directives reinforcing the importance of an ongoing evaluation of their portfolio of stocks, and of actively voting on proxies. Similarly, in the UK, financial institutions have a fiduciary duty to their ultimate beneficiaries to evaluate their investments and act on this evaluation (Charkham, 1994). Financial institutions must, therefore, safeguard their investments by monitoring and influencing firm in which they invest. This requires demonstrating an ongoing interest in the activities of these firms and the use of their voice. The simpler 'exit' mode of divesting a declining stock is not sufficient.

Meanwhile, the size and concentration of the average institutional shareholdings increase. Carleton et al. (1998) and Coffee (1991) argue that the size of institutions has several implications for activism. Many institutions have become so large that they are essentially illiquid unless the fund is either willing to accept a relatively large drop in price or to spread its sales over a long period of time. The high costs of 'exit' provide incentives for exercising 'voice' (Hirschmann, 1970). Because such shares are harder to sell, cut-and-run behaviour is reduced, and intervention becomes more attractive (Kahn and Winton, 1998). Also, their sheer size enables them to own large enough shares in their portfolio companies to overcome the free-rider problem.

In addition, a report of the Standing Senate Committee (1998) reveals that abuse of power by management or a majority shareholder is the important incentive for them to become active in corporate governance.

The fiduciary responsibility and increasing size of financial institutions provide incentives of institutional intervention in corporate governance. At the same time, financial institutions have power to monitor corporate management. Stiglitz (1985) argues that individual shareholders with relatively small shareholdings have little incentive to gather and bear the relatively fixed costs of collecting information to enable them to monitor and control the behaviour of the board. Alternatively, large shareholders may have sufficient incentives to obtain the information necessary to control management effectively if the benefits of such monitoring outweigh the associated costs. Hence, financial institutions have informational advantage over individual shareholders, and they have economic capacity to hire internal and external financial analysts to gather and digest information enabling the institutions to take thoroughly considered decisions. Furthermore, financial 
institutions gain explicit and implicit power from voting rights present in their ownership stakes (Easterbrook and Fischel, 1983). They can select or dismiss the board of directors by voting for or against board members during the annual shareholder meetings. Additionally, a strong showing of votes that are unfavourable to management can increase the threat of takeover.

Thus, with their large equity holdings, access to superior resources, and the power inherent in voting rights, financial institutions would be expected to be able to have a significant impact in corporate governance of corporations. Moreover, as they are spread out over large equity holdings, the costs incurred in monitoring activities are likely to be less than those for individual investors. Hence, financial institutions appear to have the incentives, the ability, and the methods to influence firm managers to take actions to create shareholder value and prevent them from acting in a self-interested fashion.

Accordingly, this vigilant institutional monitoring may enhance managerial efficiency and the quality of corporate decision-making, consequently, improving firm performance. Further, the involvement of financial institutions in a company may also lead to improved corporate governance structures such as procedural reforms, increased and quicker information (Pozen, 1994). Moreover, Lang et al. (1989) and Servaes (1991) provide evidence to support that financial institutions direct scarce capital to its most efficient use.

In addition, there is a need of institutional participation in corporate issues. Normally, companies with poor financial or stock price performance, or companies with some governance-related issues that are thought to be detrimental to shareholders' wealth, are usually selected as targets of shareholder activism (Choi and Cho, 2003; Romano, 2001). Poor performance has created a need for top managers to justify their performance to investors and analysts (Bromiley, 1991). Edelman (1992) notes that when faced with pressure from external sources, top managers seek to comply in a way that safeguards their own autonomy. The intervention of financial institutions buffers top managers from external scrutiny, and enables them to signal commitment to investor rights (Rao and Sivakumar, 1999).

Claessens and Fan (2002) argue that when ownership is concentrated and a firm is subject to agency conflicts between controlling owners and minority shareholders, the firm may 
invite financial institutions' equity participation so that it can borrow their reputation to enhance its credibility to minority shareholders.

\subsubsection{The extent of institutional participation in corporate governance}

Pound (1988) presents three different hypotheses that explain the relationships between institutions and their incentives to intervene in corporate governance: the efficient monitoring hypothesis, the goal conflicts hypothesis, and the strategic alignment hypothesis. The efficient monitoring hypothesis suggests that institutional shareholders are more informed and able to monitor management at lower cost than small shareholders. Alternatively, the strategic alignment hypothesis suggests that institutional shareholders and the board may find it mutually advantageous to co-operate on certain issues. Similarly, the goal conflicts hypothesis suggests that institutional shareholders may have current or potential business relationships with the firm, which make them less willing actively to curb management discretion.

Pound's hypotheses suggest that the extent of institutional intervention will depend on the relationship between the institution and the company. For example, financial institutions, such as banks and insurance companies, are more susceptible to managerial influence because of their ongoing business relations with the firms in which they invest (Sherman et al., 1998). Kochar and David (1996) report that these financial institutions are less able to influence firm strategies. Sherman et al. (1998) also find that mutual fund owners are only concerned with short-term results, which is consistent with the findings of corporate governance researchers (e.g., Useem, 1993; Monks and Minow, 1995). However, pension funds have characteristics that are similar to Coffee's (1991) notion of the 'optimal corporate monitor'. Coffee suggests that the optimal corporate monitor should be relatively free from goal conflicts such that its monitoring and control activities are not biased by opportunities to earn other income from company in question. It should also have a longterm investment horizon and its stakes in the corporation should be large enough to justify the expenditure of significant monitoring costs. Coffee argues that pension funds are in a better position than other institutions to perform this role. In practice, pension funds are demonstrated to pursue a highly active role in the governance of companies principally through the submission of shareholder proposals (e.g., Guercio and Hawkins, 1999; Prevost and Rao, 2000). 


\subsubsection{Methods of institutional participation in corporate governance}

Generally, the system of corporate governance operates through the Companies Act and recognises the power of shareholders via their right to vote at annual general meetings. The Institutional Shareholders' Committee (ISC) (1991) recommended that institutional shareholders should make positive use of their voting rights and should register their votes whenever possible on a regular basis. Furthermore, the Cadbury Report (1992) stated that, 'voting rights can be regarded as an asset, and the use or otherwise of those rights by institutional shareholders is a subject of legitimate interest to those on whose behalf they invest.' Therefore, the most common method of intervention is active use of votes at general meetings. Shareholders can actively use the right to remove or prevent special antitakeover devises such as shareholder classes or to remove incumbent management. The votes held by financial institutions may be cumulated with votes obtained as proxies for other shareholders. With the economic power of financial institutions, they possess the ability to engage in proxy contests, which private investors normally cannot do. Of course, there are a number of other actions that are available to institutional shareholders in their role as relatively large shareholders.

The first action is to refuse to partake in rights issues when companies come to the market to raise additional equity funds. Institutional shareholders are at their most powerful in such situations, for the onus is on management to negotiate with the institutional shareholders (Short and Keasey, 1997). Institutions may make the provision of additional finance subject to governance changes within company, for example, by demanding board changes, etc. Because management are appealing to institutions to support them at the time of the rights issues, many of the usual problems of organising collective action will not arise. In particular, the cost of such action to institutions will be lower as they do not have to initiate the action themselves. However, this source of power obviously arises only when companies require additional equity finance; hence, other forms of governance action are required in other circumstances.

The second is to make adverse public comment. This action may damage the firm in terms of its share price and its overall business reputation, however, it risks damaging the investing institution and other investing institutions as well. Part of the problem with such an approach is that the institution put itself in a light of being 'whiter than white' and hence 
leaves itself open to increased public scrutiny. Furthermore, although the relationship may be essentially arm's length, the institution needs the continued support of the firm if it is to access firm-specific data on a timely basis. For these reasons, the institutions may prefer to comment privately; in this way, the firm, the institution, and the relationships with other institutions are not damaged. If this form of 'quiet' policing works, then it is to the benefit of all concerned as it avoids the costs of excess volatility.

The third is the removal of directors via a general meeting. However, it seems likely that it is used in only the most extreme of circumstances. Again, this action suffers from the fact that it will damage other institutions, and hence it opens up the potential for retaliatory action.

\subsection{Factors that affect the role of financial institutions in corporate governance}

The preceding discussion assumes that if financial institutions have the incentive to intervene in firms, they will be able to successfully do so. In other words, their influence will be directly observable on firm-level outcomes. It is quite possible, however, that various structural and regulatory barriers can impede this influence. These factors can prevent institutions from fully exercising their power or motivate them to exercise it in a different direction.

In this section, the factors that affect the willingness and ability of the financial institutions to intervene to correct corporate governance failures are evaluated.

\subsubsection{The size of institutional shareholdings}

From a rational perspective, one aspect of the governance of corporations is that the costs of intervening ${ }^{13}$ must be less than the probable benefits if governance actions are to be effected. Given potential scale economies in accessing corporate data and a positive relationship between the value of shareholdings and increased firm performance, larger shareholders have greater incentives to become involved in governance issues than smaller

\footnotetext{
${ }^{13}$ Clearfield (2005) points out the costs of any direct involvement in governance initiatives could include overhead and staffing, frictional and opportunity costs, relational risks, reputational risks, and fear of retribution.
} 
shareholders. Admati et al. (1994) claim that rational shareholders will become active if the expected benefits of activism exceed the expected costs of activism. In their model, activism arises as an equilibrium condition when the expected gains from monitoring exceed the expected costs. As Stiglitz (1985) argues, individual shareholders with relatively small holdings have little incentive to gather and bear the relatively fixed costs of collecting information to enable them to monitor and control the behaviour of the board. Alternatively, large shareholders may have sufficient incentives to obtain the information necessary to control management effectively if the benefits of such monitoring outweigh the associated costs. Therefore, because of the free-rider problem associated with shareholders' monitoring and control, it requires a significantly large size for shareholders to have incentive to carry out monitoring activities (Shleifer and Vishny, 1986).

\subsubsection{Goal conflicts}

Goal conflicts may arise between the institution and its parent with regard to corporate governance matters. Actions to curb management discretion by the institution may have long-term consequences for its parent if it has current business relationships with the firm or is likely to act as an adviser to the firm on future matters, such as takeovers, rights issues, etc.

The primary intent of most shareholders is to earn a return on their investment in firms. In addition to this investment role, some institutions may also have a business relationship with firms in which they own shares. For these institutions, part of their revenue is dependent on economic exchanges with the firm, independent of their investment income from their shareholdings. For example, in addition to holding equity in firms, insurance companies may provide them with underwriting services, and banks can provide loans. Accordingly, for these investors, exchange with the firm includes two components: (1) the safeguarding of their investment, and (2) the maintenance of a business relationship. The dual nature of these activities may pose a conflict of interest for these investors (Herman, 1981; Heard and Sherman, 1987). Financial institutions should exercise influence to safeguard their investment. However, if they take an interventionist stance toward the firm, its managers may impose a penalty by severing the business relationship. Thus, the increase in investment value possible through active intervention may be nullified through loss of business with the firm. An institution's ability to influence the firm will be limited by the extent to which it depends on the firm for business. Financial institutions are thus faced 
with a dilemma - intervention may actually lead to a net decrease in value. Institutions that aim to maintain an amicable business relationship may be hesitant to intervene and question managerial actions.

There has been some research examining the effects of difference among financial institutions on corporate governance. Brickley et al. (1988) examine the role of financial institutions in checking manager initiated anti-takeover charter amendments. They report that mutual funds, endowments and foundations, and public pension funds are more likely to oppose anti-takeover charter amendments than banks, insurance companies, and trusts, investors that frequently have business relationships with companies. Similarly, in a detailed case study of the Honeywell 1989 proxy solicitation, Van Nuys (1993) shows that banks and insurance companies are significantly more supportive of managementsponsored anti-takeover proposals than financial institutions without business relationships.

\subsubsection{Regulatory environment}

Legal system within a country influences the role of institutional shareholders (Gillan and Starks, 2003). Although financial institutions have fiduciary obligations and economic incentives to exercise 'voice' to safeguard their investments, several regulatory barriers may constrain the ability of institutions to exert their influence in corporations. These regulations restrict financial institutions either by limiting their ownership stakes in individual firms, or by placing barriers to coordinated action within groups of financial institutions (Roe, 1990). With the regulatory barriers in place, the situation is considerably different. Intervention by financial institutions is more difficult because they lack the authority to force managers to directly comply with their demands. As discussed above, in Korea, laws in place prior to 1998 prevented financial institutions from voting their shares, and in Canada, the absence of a confidential voting system for shareholders inhibits financial institutions from being active as they might otherwise be in corporate governance issue.

\subsubsection{Agency problems within financial institutions themselves}

Romano (1993), Murphy and Van Nuys (1994), and Gorton and Kahl (1999) argue that financial institutions might be imperfect monitors due to their own internal agency problems. As financial intermediaries, institutional owners bring professional expertise and 
norms, however, they are complex organisations, or political systems of competing interests (Pfeffer, 1981; Mintzberg, 1983). Accordingly, institutional owners are agents themselves with their own goals, separate from goals of their beneficial owners (Garten, 1992). Jenkinson and Mayer (1992, p2) say, 'Why precisely managers of institutional funds are supposed to be so better at administering non-financial enterprises than the management of these enterprises themselves, or why similar problems of corporate governance do not afflict the funds themselves, are questions that are never clearly answered'. Indeed, there are reasons to believe that some financial institutions are less accountable to their owners than corporate managers to their shareholders, and the usual mechanisms of corporate accountability are limited or unavailable at the institutional level (Coffee, 1991). Therefore, financial institutions themselves are not immune from corporate governance problems and may be willing to draw attention to these problems by criticising the companies in which they invest.

\subsection{Institutional ownership and firm performance}

The objectives of financial institutions as both shareholders and investors should be to improve firm performance brought about by improving the standards of corporate governance (the Financial Economists Roundtable, 1998; Romano, 2001). Accordingly, since financial institutions have the incentive and ability to monitor corporate management, this monitoring role is ultimately manifested in improved firm performance.

There are generally two assumptions about the relationship between the monitoring role of financial institutions and firm performance. One is the performance-improved assumption, and the other is performance-reduced assumption. Under the two assumptions, a number of empirical studies examine this relationship, many of them utilise ownership stakes of institutional shareholders as a proxy for their willingness and ability to undertake monitoring activities (Short and Keasey, 1997).

\subsubsection{Performance-improved assumption}

Admati et al. (1994), Huddart (1993), Maug (1998a), Noe (2002), and Shleifer and Vishny (1986) argue that financial institutions enhance corporate efficiency, thus improving firm performance in two ways. First, financial institutions perform quality research in order to identify efficient firms for investing funds, thus directing scarce capital to its most efficient 
use. Second, large institutional stakes in public corporations provide strong economic incentives for financial institutions to monitor managers. This vigilant institutional monitoring enhances managerial efficiency and the quality of corporate decision-making. If financial institutions are indeed monitoring investors of management, then companies with high levels of institutional ownership could be expected to outperform those with low institutional ownership.

McConnell and Servaes (1990, 1995) find that the percentage of shares owned by institutions to be positively and significantly related to Tobin's $\mathrm{Q}$, and that institutional ownership acted to reinforce the positive effect of directors' shareholdings on firm performance, a result they suggest was consistent with the efficient monitoring hypothesis (Pound, 1988). Chaganti and Damanpour (1991) document institutional ownership to have a significantly positive effect on the return on equity, but not on other measures of firm performance (return on assets, price earnings ratio, and total stock return). With a sample of 301 firms over a period from 1988 to 1992, Han and Suk (1998) report that stock returns are positively related to institutional ownership, indicating institutional owners are active in morning management. The study of Short and Keasey (1997) shows that the relationship between firm performance and institutional shareholdings is complex, affected by interactions with other shareholding parties. When considered independently of other ownership interests, there is no significant relationship between performance and institutional ownership. However, the results do suggest that the presence of institutional shareholders acts to curb management discretion by strengthening the positive relationship between performance and directors' ownership. This finding is consistent with that of McConnell and Servaes $(1990,1995)$. Furthermore, they also report an interaction between institutional shareholdings and other external shareholders, in that institutional shareholdings have a significantly positive effect on performance, only in the absence of other large external shareholders.

\subsubsection{Performance-reduced assumption}

This assumption holds that financial institutions are incapable of monitoring managers due to their passivity, myopic goals, conflict of interests, and lack of expertise.

It is argued that financial institutions are passive and are more likely to sell their holdings in poorly performing companies than to expend their resource in monitoring and improving 
their performance (see, Drucker, 1986; Graves, 1988). It is further argued that many financial institutions take a myopic view of their investments, guided solely by the shortterm (e.g., quarterly) goal of outperforming some benchmark. This short-term perspective leads to overreaction to information and excessive trading, and renders these investors incapable of monitoring managers. Furthermore, many institutions, such as insurance companies, may have business relations with companies in which they also hold shares. These business relations may lead to inside trade, which may prevent financial institutions from being active corporate monitors (David and Kochhar, 1996). In addition, institutional shareholders' attempts to influence corporate decisions tend to disrupt the firm's operation, as they are lack of expertise (Wohlstetter, 1993). Therefore, the assumption predicts a negative relation between firm performance and institutional ownership of portfolio companies.

Woidtke (1996) finds a negative relation between firm performance (industry-adjusted Tobin's Q) and the percentage of ownership by activist public pension funds. Craswell et al. (1997) report no evidence to support that institutional ownership is an important determinant of firm performance in Australia. Using a sample of 118 corporations drawn from five industry sectors in Japan, Chowdhury and Geringer (2001) fail to find a direct relationship between institutional ownership and productivity. Balatbat et al. (2004) examine ownership structures and corporate governance attributes of 313 Australian initial public offerings between 1976 and 1993. They find that operating performance of Australian IPOs typically deteriorates over the first 4 post-listing years. Evidence of a positive relation between institutional ownership and performance is restricted to the latter part of their 5-year post-listing window.

In summary, it is clear that the empirical analysis of the relationship between institutional shareholdings and performance has produced conflicting findings. Different time period, sample sizes, and types of events examined may account for the discrepancies among previous empirical studies (Karpoff, 2001). However, no matter whichever assumption examined, all above studies about the relationship between institutional ownership and firm performance support for the agency theory from two different sides.

In addition, empirical problems exist in attempting to model the relationship between institutional ownership and firm performance. For example, much research is constrained 
by the use of publicly available data on institutional ownership. Also, by focusing on the presence of institutional shareholders and/or the percentage of shares owned by institutions, there is an inherent assumption that a certain level of institutional shareholding is associated with a certain level of monitoring activity.

\subsection{Summary}

Financial institutions became a significant component of equity markets during the latter half of the twenties century. The increased institutional ownership and fiduciary duty provide economic incentives for financial institutions to exercise their 'voice.' As equity owners, financial institutions have the potential to influence management's activities directly through their ownership, or indirectly by trading their shares. Institution activists engage in corporate governance activities mainly through introducing proposal and negotiating with management, with the stated goal of improving firm performance.

With respect to the role of financial institutions in corporate governance, some authors claim that activist efforts increase firm value by ameliorating agency conflicts and prompting specific actions, while a competing view holds that shareholder activism tends to impair firm management and degrade firm performance. A third view is that shareholder activism has negligible effects on firm performance.

Much of the empirical literature utilises ownership stakes of institutional shareholders as a proxy for their willingness and ability to undertake monitoring activities. However, the relationship between institutional ownership and firm performance has produced conflicting findings.

Financial institutions appear to have the incentives, the ability, and methods to influence firm managers to take action to create shareholder value and prevent them from acting in a self-interested fashion. However, it is quite possible that various factors can impede this influence, such as the size of institutional holdings on incentives, goal conflicts, barriers from regulatory environment, and agency problems within financial institutions themselves.

I review the literature of the effectiveness of corporate governance systems in the preceding chapter and the role of financial institutions in corporate governance outside China in this chapter. These studies are mainly based on the developed economies, especially in the US 
and UK. From the next chapter I turn the focus to China, a transitional economy as well as an emerging economy, which is also a unique departure from existing work on the US and UK. 


\section{Chapter Five}

\section{General Background, Corporate Governance and Financial}

\section{Institutions in China}

\subsection{Introduction}

The previous chapters discuss the effectiveness of corporate governance systems and the role of financial institutions in corporate governance in developed economies, mainly in the US and UK. In the developed economies, the increase of institutional ownership provides strong economic incentives for financial institutions to be active monitors. Starting from this chapter, focus will be turned to China to explore the role of Chinese financial institutions in corporate governance of listed companies. This chapter provides an institutional background to undertake the qualitative and quantitative research.

Aoki and Kim (1995) argue that two sets of factors must be considered in analysing corporate governance in transitional economies. One is the special designs of governance systems based on specific conditions during the process of transition. The other set of factors to consider is that the corporate governance mechanisms prevailing today in developed Western economies may not be the only effective mechanisms or may not effectively at all in special economic and social contexts.

Hence, to analyse corporate governance in China, this chapter first presents the specific environment under which corporate governance operates in Sections 2, 3, and 4. Section 2 briefly introduces the Chinese economy and economic reform, followed by "the development of Chinese stock market" in Section 3, and "state-owned enterprises and listed companies" in Section 4. Section 5 depicts the characteristics of the corporate governance of listed Chinese companies. Sections 6 and 7 investigate the effectiveness of the internal and external governance mechanisms in the Chinese context respectively. Section 8 discusses the characteristics and the perceived role of Chinese financial institutions in corporate governance of listed companies. The final section provides a summary. 


\subsection{The Chinese economy and economic reform}

China is a developing country with the characteristics of a transitional economy as well as an emerging market economy, tightly controlled by the party/government (Xiao et al., 2004a).

China is the most populous country in the world and the fastest growing economy over the past years. Chinese annual GDP now exceeds 10 trillion yuan, ${ }^{14}$ which at the official exchange rate makes China the sixth largest economy in the world behind the United States, Japan, Germany, the United Kingdom, and France (Editorial Note, 2003).

Beginning in the late $1970 \mathrm{~s}$, Chinese economic reform has been undertaken under the central leadership of the Communist Party of China (CPC). The reform did not adopt a bigbang approach to transform the economy, neither did it engage in large scale privatisation, in contrast to other former socialist economies that have enforced a radical set of changes together with full implementation of a privatisation programme. Chinese reform experience has been unique, in the sense that it did not start with a blueprint or a clear ultimate objective of market economy, but with a trial-and-error strategy "crossing the river by groping for stones along the way." Not only did this strategy inevitably lead China to take a gradualist approach, with an experimental beginning for every new reform measure, but it also stimulated policy makers to be open-minded and consider all possible means that might be effective in reforming its existing Soviet-type planning system (Liu and Garino, 2001).

Summarising Chinese experience of reform, a World Bank study (1997) concludes that China is in the midst of two historic transitions: from a rural, agricultural society to an urban, industrial one, and from command to a market economy.

\subsection{The development of Chinese stock market}

Chinese stock market was officially established in 1990 when eight firms first went public in the Shanghai Stock Exchange (SHSE). In the following year, the Shenzhen Stock Exchange (SZSE) was established. Since then, Chinese two bourses have been among the fastest growing stock market in the world. By the end of 2003, 1287 companies were listed

\footnotetext{
${ }^{14} £ 1=\mathrm{RMB} ¥ 15.8$ at the end of 2003 .
} 
on the two stock exchanges with total market capitalisation $4,245.77$ billion yuan, compared with 53 companies with 104.81 billion yuan in 1992.

The very justification for starting a stock market in China was to help the State-Owned Enterprises (SOEs) raise capital from general public and improve SOE performance through public listing, and it was not to offer the public a way to diversity investment portfolios and hedge future consumption/income risks (Chen, 2003; Walter and Howie, 2003).

The share structure with the co-existence of A-, B-, and $\mathrm{H}$-shares ${ }^{15}$ represents one of the distinctive features of Chinese stock market from those in other countries. In terms of share ownership, three different types of shares are issued: state, legal person and individual. All shares of the same company have the same ownership rights. The predominant type is Ashares. These are listed in China, denominated in $\mathrm{RMB}^{16}$ and their sales were restricted to domestic investors. In 2002, Qualified Foreign Institutional Investors (QFII), with the approval by the China Securities Regulatory Commission (CSRC), were allowed to participate in A-shares market. B-shares are also listed in China and denominated in Hong Kong dollars or US dollars, and until June 2001, their purchase was restricted to foreign investors using foreign currency. The third type of shares is H-shares, which are issued in Hong Kong. While most companies only issue A-shares, the majority of B-share or H-share issuing companies also issue A-shares. By the end of 2003, among the total 1287 companies listed on the SZSE and SHSE, 89 per cent of total companies, i.e., 1146 issue only A-shares in 2003. Among the 111 B-share issuing companies, only 24 companies, or 2 per cent of total companies issued B-shares exclusively; the rest also issued A-shares. Among those 93 companies that issue H-shares, 29 also are listed in Shanghai or Shenzhen, and the rest are not, that is, only 64 companies, or 5 per cent of total shares only issued Hshares. Most of the H-share issuing companies, 77 out of 93, are listed in Hong Kong.

A related feature is large differentials in prices among these shares issued by the listed companies with similar or even same business and operating performance. This is also

\footnotetext{
${ }^{15}$ Shares listed in North America were used to being called $\mathrm{N}$ shares. Now they are also referred to as $\mathrm{H}$ shares.

${ }^{16} \mathrm{RMB}$ stands for Renminbi, i.e. people's currency. In the end of 2003 , the exchange rate was about $£ 1=\mathrm{RMB}$ $¥ 15.8$.
} 
illustrated by the average PE ratios ${ }^{17}$ being currently around 50, 25, and 10 for A-share, Bshares, and H-shares, respectively. Such a phenomenon is apparently attributed to different investors and currencies involved in these shares. This is in turn due to different perceptions of Chinese companies between local investors and overseas investors, as well as to limited investment options for local investors.

Unlike the norm in stock markets elsewhere, state shares and legal person shares, which account for 65 per cent of total number of shares issued as of 2003 , remain non-tradable, in principle, even after a company is listed, while tradable public shares being only 35 per cent. State shares can only be transferred to other institutions via private negotiations, and legal person shares used to be only transferable via private placements. ${ }^{18}$ This represents another distinctive feature of Chinese stock market.

State shares exist in China to designate holdings in the SOEs by the central government, local government, and solely government-owned enterprises (Sun and Tong, 2003). To preserve the economy's socialist structure, SOEs have to issue shares to the government when going public and the proportion is substantial, presenting over 30 per cent of total shares on average. The presence of an influential state shareholder in most listed Chinese companies represents a unique feature of the Chinese corporate sector (Gul, 1999; Qi et al., 2000).

Legal person shares are held by domestic institutions, e.g., industrial enterprises, financial institutions, foundations, funds, and research institutes. In terms of their ownership structure, most of those institutions are either directly state-owned or controlled largely by the public sector. Thus, in most cases, the state is directly (through state shares) or indirectly (through legal person shares held by SOEs) in control of listed companies (Tenev et al., 2002). The high concentration of ownership combined with more than two-thirds of non-tradable shares implies that few listed companies are subject to contestable control, limiting the potential pressure that capital markets could exert on the corporate governance of listed companies.

\footnotetext{
${ }^{17} \mathrm{PE}$ ratio is the result of share price divided by earnings per share. In general, firms that the market believes have better prospects have higher PE ratios.

${ }^{18}$ However, since 1998, auction houses have been conducting semi-public auctions for the legal person shares in major cities, predominantly in the Shenzhen area. In any case, transfer of legal person shares requires CSRC permission.
} 
A shortage of tradable shares-only 35 per cent of total equities-coupled with the predominance of small-cap stock render the stock markets vulnerable to short-term speculation and share price manipulation. In addition, the lack of core blue-chip companies and the multitude of different share classes (A, B, and $\mathrm{H}$-shares) make it hard to construct a satisfactory index benchmark against which performance can be measured. Often blamed for the problems of Chinese volatile stock markets are large numbers of speculative retail investors. However, institutions - securities companies, privately placed funds, and even some licensed investment managers-are also exhibiting short-term oriented investment behaviours no different from retail investors.

With respect to laws, regulations and supervisions, the government established the State Council Securities Commission (SCSC) and the China Securities Regulatory Commission (CSRC) in 1992 as primary regulators. The SCSC and the CSRC were then merged in April 1998 to form one ministry rank unit (i.e., CSRC) directly under the State Council as part of the government's plan for improving regulatory effectiveness. The government controls both the listing of new enterprises and the value of new stock issued through its regulatory bodies (Gordon and $\mathrm{Li}$, 2003). In August 1998, furthermore, the Shanghai and Shenzhen stock exchanges were placed under the supervision of the CSRC. In November 1998, the authority to supervise local securities regulatory departments was transferred from the People's Bank of China (PBOC) to the CSRC. The Company Law-containing provisions on issuance, transacting, and listing of public securities - was introduced in 1994. The Securities Law, which contains provisions on issuing and trading of securities, takeover of listed companies, was adopted in December 1998, and effective on $1^{\text {st }}$ July 1999, aiming to prohibit insider trading, standardise the issuing and trading of securities, improve disclosure, and protect investors, safeguard the economic order and public interests of society.

In a bid to liberalise the market for initial public offering (IPO), the CSRC formally scrapped the quota system for IPOs in March 2001. Prior to 2001, whether a Chinese company could make an IPO was determined largely by an administrative process rather than the market process seen in developed economies. When a SOE wants to go public, it must seek permission from the local government or/and its affiliated central government ministries, which receive an IPO quota from the CSRC. Unfortunately, there are no explicit rules governing quota allocations. Information on how much quota is issued to whom is 
hard to obtain. In 2000, the government decided to abandon the quota system and let the market determine which firm can go public. The first non-quota IPO appeared in 2001. Under such a quota system, how many and which firms go public each year depends not only on the quality of the firm and on macroeconomic conditions, but also on the availability and distribution of the quota. The scrapping of the quota system for listing companies makes the selection of listing firms more transparent and less dependent on the government. The move also helps to ensure that companies listing on the local stock exchanges are of higher quality and the investment funded by the equity financing is more efficient and profitable.

To promote the restructuring of SOEs, the CSRC has taken measures to sanction false disclosure and market malpractices, and to require all listed companies to meet international audit standards since the beginning of 2001. Tougher rules on de-listing, namely, "Suspending and Terminating the Listings of Loss-making Listed Companies Implementing Procedures" were put into effect in February 2001. From then on, firms that register losses for three consecutive years will immediately be suspended from trading. If such a firm fails to show financial recovery within six months, de-listing will automatically follow. ${ }^{19}$ De-listing of SOEs would send a strong signal to corporate executives and investors alike that Chinese stock market no longer serves as a refinancing apparatus for SOEs with questionable commercial prospects. To further standardise the corporate governance of listed companies and enhance their standardised operation, in August 2001, the CSRC issued the "Guidelines for Introducing Independent Directors to the Board of Directors," so listed companies were required to have at least one-third of the board to be independent directors by June 2003.

To promote the establishment and improvement of modern enterprise system by listed companies, standardise the operation of listed companies, and bring forward the development of the securities market, in January 2002, the CSRC introduced the "Code of Corporate Governance for Listed Companies in China" that stipulates the means for the protection of investors' interests and rights, the basic behaviour rules and moral standards for directors, supervisors, managers and other senior management members of listed companies.

\footnotetext{
${ }^{19}$ The first de-listing came in April 2001 when washing machine maker Shanghai Narcissus Electronics was forced off the Shanghai Stock Exchange.
} 
In October 2002, the accounting rules were tightened for companies seeking IPOs in an attempt to improve the quality of listed companies. In the same month, the CSRC unveiled a new rule that permits domestic and foreign investors to buy controlling stakes (over 30 per cent), laying the legal ground for the acceleration of mergers and acquisition.

In December 2002, the long-waiting Qualified Foreign Institutional Investors program, better known as QFII, offered foreign investors access to invest in local-currency denominated securities (including A-shares) with the ceiling of 10 per cent of shares in a listed company per each QFII and 20 per cent of total shares for the first time. This signals a significant step toward capital market opening in China. Positive developments have taken place since the QFII program was launched in December 2002. In January 2003, the CSRC and PBOC approved seven domestic and three foreign banks as QFII custodians. These banks are Industrial and Commercial Bank of China, Bank of China, China Merchants Bank, China Construction Bank, Agriculture Banks of China, Bank of Communications, China Everbright Bank, HSBC, Standard Charted and Citibank. Evidently, both local and foreign banks are interested in building expertise in this business area, citing strong growth potential and the considerable fee-based income from scale operation.

More recently, on $29^{\text {th }}$ April 2005, the CSRC released the "Notice of the Pilot Projects of Reform of the Segmented Share Structure." Widely viewed as one of the major problems blamed for Chinese sluggish stock market, the segmented share structure refers to the existence of a large volume of non-tradable state-owned and legal person shares (People's Daily Online, $16^{\text {th }}$ May 2005b). This means only about one-third of the shares in domestically listed companies float on the stock markets. The structure puts public investors in an inferior position relative to the actual controllers in making corporate policies and disposing of the companies' profits and assets. The newly-launched reform to tackle the segmented share structure reflects the will of the central government and the companies' enthusiasm for reforming the existing share structure of the domestic stock market. Merging tradable and non-tradable shares eliminates the existing division between two classes of shareholders with different, if not conflicting, interest, and ensures that all shares of the same company have the same ownership rights. On $8^{\text {th }}$ May 2005 , four listed companies were chosen to be the first batch of pilot projects of the reform. 
According to Fulin Shang, the chairman of the CSRC, who made the remark in the interview with XinHua Press (People's Daily Online, $16^{\text {th }}$ May 2005b), the reform will be carried out in three stages. The first phase of the reform is the ongoing trial program. Through the pilot projects in a few companies, China will explore methods on how to form the stock prices by the market while maintaining the stability of the market. In the second stage, with continuous feedback from the trial program, China will issue a series of related rules and regulations to create favourable condition for further reform. The rules are aimed to protect the legitimate interests of investors and enhance the adaptability of the market for reform. In the third stage, with experience from the first batch of companies, China will expand the pilot projects.

\subsection{State-owned enterprises and listed companies}

\subsubsection{The history of Chinese SOE reform}

In China, Stated-Owned Enterprises (SOEs) are firms legally owned by the state and administered either by various industrial ministries in the central government or by local (provincial or municipal) governments (Qi et al., 2000). SOEs used to be the most important part of the economy, accounting for 90 per cent of the output in 1980 and employing the majority of urban work force. However, since the reform in the late 1970s, their importance has declined very dramatically. In 2003, the output of state sector only contributed less than one third of the total output (Wang, 2003).

Chinese economic and SOE reform process officially began with the Third Plenum of the Eleventh Central Committee of the Communist Party of China (CPC) in December 1978. According to Wei (2003), the reform process can be divided into three stages. The first stage started in 1978. It focused on decentralising governmental authority in enterprises and on increasing the operational autonomy of enterprises' managers. Managers were given greater autonomy over the allocation of profits and resources of enterprises. However, before mid 1980s, SOE reform took place mainly at provincial level and those reform measures were largely experimental.

With increasing expectation of improvement in enterprise efficiency, the second stage of enterprises reform was begun in the mid 1980s. The major change of this period was to grant SOEs more autonomy and financial incentives to managers. In May 1984, the State 
Council issued "On Regulations of Further Expanding Autonomy of State-owned Enterprises," which allowed SOEs more autonomy in production and profit retention. In January 1987, the government started promoting "contract responsibility system." (chengbao zhi) ${ }^{20}$ Combined with the "dual-track price system," 21 this measure gave SOE managers more financial incentives and consequently SOE performance improved. By the end of 1987, about 80 per cent of the large and medium-size SOEs adopted contract responsibility system, and by 1989 almost all SOEs adopted this system (Wang, 2003).

The $14^{\text {th }}$ Party Congress in October 1992 announced the target of constructing a socialist market economy and establishing a modern corporate system, which spearheaded the third stage of the SOE reform, corporatisation (gongsihua). In November 1993, the Third Plenum of the Fourteenth Party Congress adopted "Decision on Issues Concerning the Establishment a Socialist Market Economic Structure," which provided a package of reform measures to carry out the vision of a "socialist market system" set forth by the Fourteenth Party Congress. The Decision set forth the task of transforming SOEs into "modern enterprises" with "clearly clarified property rights, designated authorities and responsibilities, separated functions between government and enterprises, and scientific management." In December 1994, the State Council proposed a pilot scheme for a few large SOEs. This led to the policy of protecting the large (SOEs), releasing the small (zhuada fangxiao) (Hong Kong Economic Journal, $19^{\text {th }}$ September 1997). The government kept a firm grip on one hundred central and 2,600 local large SOEs. Many weak enterprises were sold off through auctions and corporate transformation while some large- and medium-sized SOEs were transformed into publicly listed firms on the stock market. Only relatively strong SOEs were eligible to go public. After 2002, ownership reform became the focus of SOEs reform and shareholding companies was set to become the main form of SOEs. In October 2003, the Third Plenum of the Sixteen Party Congress issued "Decision Concerning Issues of Perfecting Socialist Market Economy System." For the first time, the Party acknowledged property rights as the "core issue" of ownership reform and made building "modern system of property rights" its important task of future reform.

\footnotetext{
${ }^{20}$ In the contract responsibility system, all SOEs would sign an individually negotiated contract with their supervising agency, which specified the exact amount of revenue that should be turned over to the state. This new institutional arrangement separated the owners from managers, but only on paper, as local governments still kept intervening in operational decisions of SOEs.

${ }^{21}$ To improve the inefficient price system of the planned economy, the government undertook price reform in 1985. They introduced dual-price system, which allowed SOEs to buy and sell the above-quota inputs and outputs at market prices.
} 


\subsubsection{The listed company}

It is believed that listed companies are among the best corporations in China. The government gives preferential treatment to better-managed SOEs to allow them to be listed and to raise capital in the stock market. The majority of listed Chinese companies started off as state-owned/ state-controlled enterprises. Some of them were re-organised and restructured using certain assets carved out from SOEs. With the offering of shares in the open market, this has attracted a large number of individual and financial institutions. Therefore, the governance and performance of listed Chinese companies has enormous economic significance on both the economy as a whole and the wealth of individuals.

Listed Chinese companies have the following typical company structures: (1) Ownership in listed companies is relatively highly concentrated. Data from $2003^{22}$ indicate that among all the companies listed in Shanghai and Shenzhen, the largest three shareholders held, on average, about 48 per cent of total shares, of which the average shareholding of the largest shareholders is about 42 per cent, of the second largest is 3 per cent, and of the third largest is 2 per cent. (2) The percentage of state ownership is relatively high. Due to restrictions in market capacity when offering shares to the public, the percentage of shares available to the open market is relatively low. After the offering, more than half of the available shares were held by the promoters. This has enabled the control of the company to remain with the promoters who are state-owned shareholders or state-controlled shareholders. (3) The percentage of tradable shares is relatively low. Based on existing regulations, a large volume of state shares and legal person shares are not traded, and only about one third of individual share float on the stock markets. In addition, for listed companies that went public in the earlier days, shares held by the public cannot be traded on the open market until three years after the company has been listed. This further reduced the percentage of tradable shares. (4) Number of individual shareholders is relatively high. Chinese stock market is primarily made up of individual investors and lack financial institutions (Zhang, 2002). These individual investors are segmented, segregated and shareholding ratios are relatively low. In addition, other factors including geography, time-zone, etc., further restricts individual investors' participation in the management and significant-decisionmaking process of listed companies. (5) Carving out. Apart from the special characteristics of the company structure, another attribute specific to listed companies in China is the process of "carving out assets" during corporatisation and initial public offering phase. To

\footnotetext{
${ }^{22}$ The Sinofin database.
} 
form a listed company, promoters would normally "carve out" all or a portion of its operating assets (e.g., a factory, a workshop, or even a production line) and contribute this into the listed company. Assets not attributable to operations and/or other remaining assets are generally left behind. Consequently, the promoters and the listed company still maintain on-going business relationships, for example, up-stream and down-stream in the supply and demand chain. As a result, significant related party transactions exist.

\subsubsection{Agency problems in Chinese companies}

\subsubsection{Ineffective state ownership}

Although Stiglitz (1994) argues that the nature of those principal-agent problems may differ little depending on whether ownership is public (state) or private, property rights theory generally suggests that state ownership is ineffective.

In Chinese SOEs, the owner-manager relationship is broken down into two other agency relationships, i.e., the public as owners-to-politicians and politicians-to-managers (Cuervo and Villalonga, 2000). The relationships are among all the Chinese people, the People's congress, the central (or a local) government, the state's assets administration bureau, a state-owned holding company, and the chairmen or CEOs of the firms (Fan et al., 2002). The firms are owned by the state, which in turn represents the people of China, and this ownership operates through government bureaus and departments at the central or principal levels. As Perkins (1994) notes, ownership by all of the people really means a sense of ownership by none of the people. The assets are only conceptually owned by the people and are managed by government officials (politicians). The state lacks a clear, accountable representative to enforce its will (Qian, 1996; Steinfeld, 1998), the positive effect of concentrated state ownership is limited (Mar and Young, 2001). As a result, despite the majority ownership, the state does not exercise effective control over their companies (Tam, 2002).

Moreover, as the representative of the ultimate owners, the politicians, who are supposed to ensure that managers run the firms efficiently, have little incentive for diligently monitoring managers, as the control/voting and cash flow rights associated with state shareholdings are segregated in China (Zou and Adams, 2004). Government bodies effectively hold 100 per cent of the control rights but have no cash flow rights, as all cash flows accrue to the 
Ministry of Finance (MOF). This situation can lead to severe agency problems (Berkman et al., 2002). Meanwhile, the politicians overseeing listed companies are paid civil service salaries that not directly linked to the financial performance of the firms that they oversee, and they are neither rewarded for good performance nor penalised for bad performance. Also, these politicians have their own goals, such as maximising their political base (Shleifer and Vishny, 1994), and political interference may divert managerial objectives away from profit maximisation towards such objectives as employment maximisation (Willamson, 1985). As a result, they have neither incentive nor capability (e.g., due to the lack of information and/or entrepreneurial expertise) to effectively monitor the operation of SOEs under their control on behalf of the public.

\subsubsection{Entrenchment of managers}

Agency theory assumes that managers have no objective to maximise profit, and views managerial discretion as an opportunity to serve their own objectives rather than those of the firm and shareholders. In a transition economy, which lacks independent accounting, auditing, and property evaluation institutions, there is a high moral hazard that agents may take advantage of the information asymmetry (Zhou and Wang, 2000). Since the state representatives have neither incentive nor capability to effectively monitor corporate management, managers have relatively wide discretion in running companies. Byrd (1983) has observed that overinvestment has been encouraged by the growth of enterprise discretionary funds and increased availability of bank loans.

In China, managerial labour market are underdeveloped, most board members and managers aspire to a civil service rank, salaries for different categories of managers are usually low and undifferentiated. Furthermore, stock-based incentives are weak, because managers usually hold an insignificant numbers of shares, and stock options have not yet fully developed (Tenev et al., 2002). As a result, most of listed Chinese companies lack compensation schemes that tie managers' incentives to firm performance. Externally, managers of most listed companies are still shielded from competitive pressure to strive for profits. In China, an active market for corporate control does not yet exist. Given the lack of appropriate compensation and external pressure, managers of listed companies have not only the incentive but also the ability to entrench themselves at the expense of firm performance (Tam, 2002; Shi and Weisert, 2002). 
Salary, bonuses, and shares are only a few ways in which managers are rewarded. In a rentseeking society like Chinese, on-the-job perks (e.g., better housing, use of cars, entertainment, restaurant meal, travel, diversion of asserts, and business opportunities) associated with the position of manager in listed companies can be substantial (Qian, 1995). In some cases, the firm managers and state-appointed overseers may collude to tacitly consent to jointly expropriate wealth from the firm (Lee, 1993).

\subsubsection{The expropriation of minority shareholders}

Owing to the lack of effective monitoring mechanisms, controlling shareholders and the management usually exert excess control on the company. This facilitates immoral and opportunistic behaviours aimed at pursuing private gains rather than the best interest of the company and shareholders.

In addition, given the historical relationship between listed companies and unlisted parent companies, some government bureaus and other SOEs are also shareholders in listed companies, and are often classified as state and legal person shareholders and normally account for two-thirds of total shares. It is well known that the segmented share structure puts public investors in an inferior position relative to the actual controllers in making corporate policies and disposing of the firms' profits and assets, as well as majority shareholders with non-tradable shares.

Hence, the main agency problem becomes the expropriation of minority shareholders by controlling/majority shareholders. Furthermore, the fact that most listed companies are spin-offs from large SOEs with parent groups serving as their largest shareholders compounds expropriation problems between controlling shareholders and minority investors (Chang and Wong, 2004).

Typical opportunistic behaviours include:

(1) transferring and appropriating company's profit and assets through unfair related party transactions. For example, the controlling shareholders may seize a large amount of listed company's fund; the large shareholders may sell commodities, "services," and assets with "water content" at unfavourable prices to the listed companies; 
(2) neglecting conflicts of interest and engaging in self-dealing in pursuit of private gains. For example, insiders may use company's resources for personal consumption; they may approve their own extravagant compensation packages despite severe losses of the company. "Poor company and rich insider" is not a rare combination in China;

(3) cheating on profit level to meet public offering requirements, manipulating IPO and secondary market prices, and trading on insider information, engaging in deceiving public investors for private gains through outright misrepresentation; and

(4) developing connections by using companies' resources. For example, insiders may favour nepotism and appoint only those with certain background (e.g., Qian, 1995; Lee and Hahn, 2001; Qiang, 2003).

\subsection{Corporate governance system in listed Chinese companies}

\subsubsection{The legal framework of corporate governance in China}

The current legal framework of corporate governance in listed companies is mainly based upon the Company Law, as well as dozens of regulations issued by various regulatory authorise. Under this framework, there are three general levels in the power structure that govern a company. The highest level is the shareholders' general meeting. Shareholders are the owners of a listed company and corporate governance structure is required to protect shareholder rights to know and participate in major decisions of the company. Shareholders' general meeting works as the company's power organ. The second level consists of the board of directors, the primary source of direction, and the supervisory board. A listed company must be governed by its board of directors who are elected by shareholders. To protect small shareholders' interest, the CSRC required one third of all board members are independent, in the sense that they are not related to the listed company or its controlling shareholders. A supervisory board is also required to monitor directors and managers for the best interest of shareholders. In case when their rights are violated, shareholders can pursue civil litigation for financial compensation. The third level is the manager, who is responsible for daily operations. This framework is meant to protect shareholders' interest to the greatest extent. Unfortunately, this purpose has not yet been fully achieved in practice. 


\subsubsection{The characteristics of corporate governance system}

The "insider control" viewpoint can be used to summarise the main internal governance characteristics of Chinese enterprises. Aoki (1995) maintains that in an economy that is shifting to a new structure, due to the stagnation of a planned economic structure and the delegating of power to lower levels, enterprise managers have obtained irreversible authority. Yet taking advantage of the vacuum in supervising, and restricting power after the disintegration of a planned economy, managers have further intensified their control and have mastered the control authority de facto or according to law, with their interests fully reflected in the corporate strategic policy decisions (Chen and Huang, 2001).

The concentrated ownership structure in reality often leads to insider control of the company, in which ownership or control is concentrated in the hands of a small number of individuals, managers, directors, holding companies and other non-financial corporations (Lin and Tang, 2001; SHSE, 2003). Despite its majority ownership, the state does not exercise effective control over its companies. The control of Chinese companies rests primarily with the insider-managers who are often in turn controlled and supported in various forms by their Communist Party and ministerial associates, and do not always act in the interest of the shareholders ( $\operatorname{Lin}, 2004)$. Thus, in reality the governance and the purpose of the firm are determined by the insiders. Generally, insider control becomes a system of "one-man rule" by an all-powerful CEO (zongjingli or general manager), who dominates the control and management of Chinese firms (Lin, 2001). The CEO is first and foremost an agent of the controlling shareholders and follows the latter's instructions. A report from the World Bank (Tenev et al., 2002) concludes that controlling shareholders in China often overstep the bounds of shareholder meetings and boards of directors and exercise direct effective control.

A related feature is that in the condition of highly centralised equity, the degree of participation in corporate operational policy decisions by small and medium-sized shareholders is quite low, and these shareholders, especially ones with small shareholdings, lack the motivation and means to oversee and restrict managers. Data from statistics shows that only 36.6 stakeholders on average attended their shareholders' meetings in 1198 listed companies in $2002 .^{23}$

\footnotetext{
${ }^{23}$ The Sinofin database.
} 
Another distinctive characteristic of corporate governance in China is the government interventions in listed companies (Tam, 2002; Lin, 2004). Listed companies, in spite of the fact that they are independent legal entities subject to the Company Law, still operate under the strong influence of the government. For example, in the area of appointment to the position of the board chairman and members, chief executives and supervisory board, the Chinese government and the Party organisations can exert a critical influence. Government exerts much influence on listed companies and the company's objective is affected by political consideration and derived from maximising shareholder's value.

\subsection{Internal corporate governance mechanisms}

\subsubsection{Ownership}

The total shares of listed Chinese companies are almost equally divided among state shares, legal person shares, and tradable shares. Chen and Strange (2004) suggest that the proportion of state ownership is too high in the present ownership structure, and ownership is relatively highly concentrated.

The high concentration of ownership, combined with the relatively small portion of tradable shares implies that few, if any, of listed Chinese companies have contestable control. Perhaps the most important implication of the dominant role of state ownership in listed Chinese companies is the control the government can exert over management appointments and incentives, and thereby over companies' behaviour.

On the other hand, the ownership structure is relatively stable. The concentration, although quite high, has shown a slight tendency to decrease: HERF_10 has decreased from 0.0245 in 2001 to 0.0230 in 2003 . $^{24}$

Another characteristic of ownership structure is the dominant position of other corporate entities as shareholders. In terms of types of largest shareholders, China is absent of significant ownership by individuals and families and the negligible role of financial institutions ( $\mathrm{Lu}, 2003)$.

\footnotetext{
${ }^{24}$ Data are from the sinofin database. HERF_10 is the Herfindahl index calculated as the average of the sum of squares of percentage of shares held by each top ten shareholder. Normally, HERF_10 $>0.025$ suggests that the percentage of the top ten shareholders are distributed unbalanced.
} 
Although Chinese companies have high concentration of state and legal person shares, the potential positive effect of such an arrangement is absent because of the dispersal of state representation (Mar and Young, 2001). A World Bank report (Tenev et al., 2002) suggests that the present structure of state ownership and control of enterprises accounts for their poor performance.

\subsubsection{Board of directors}

According to the Chinese Company Law (1993), a listed company must be governed by its board of directors who are elected by shareholders. A board of director should consist of 5 to 19 directors. Based on a survey of 257 companies listed on the Shanghai Stock Exchange, a World Bank report (Tenev et al., 2002) shows that the average size of boards in 1999 was 9.9, two-thirds of all directors were executive directors, and only 3.1 per cent of all directors had some degree of independence. The survey revealed that most listed companies did not have a system in place for establishing board committees, and only 5.4 per cent of the companies had established sub-committees such as finance committee, audit committee, and strategy committee. Among the committees established, investment committees and financial management committees were composed predominantly of executive directors, while strategy committees had a higher percentage of non-executive independent directors. State and legal person shareholders appoint most of the board directors, while the others are appointed by the government (Allen et al., 2005).

The board of directors is not independent enough and lacks of system of mutual balance and check in listed Chinese companies. One the one hand, the chairman of board of directors serves both as the general manager. Studies with substantial evidence have indicated that the decision-making duty of the board of directors of an enterprise cannot really be separated from the managers' duty of implementing the decisions (Chen and Huang, 2001). On the other hand, very serious is the phenomenon of the basic overlapping of board members and managers, or the overlapping of most board members and managers, thus executive board members are dominant in the boardroom. The World Bank report (Tenev et al., 2002) reveals that about half of the executive directors take senior management position.

Compared with practices in other markets, Chinese boards have relatively little decisionmaking power within the existing legislative framework, while government ministries and 
commissions and securities regulatory authorities enjoy substantial decision-making power. Major strategic decisions are agreed upon beforehand among the key shareholders (typically the state), often outside the formal shareholders' meeting or boardroom. Board chairs are usually the representatives of largest shareholder to exert control over shareholder meetings.

\subsubsection{Supervisory board}

The Chinese Company Law requires all listed companies as well as non-listed joint-stock companies to have a supervisory board, in addition to its board of directors. Provided by Company Law and Code of Corporate Governance for Listed Companies, ${ }^{25}$ the key role of supervisory board is the financial supervision of the company, as well as to supervise the due diligence of directors, managers and other senior management personnel, safeguard the company's assets, reduce the company's operational and financial risks, and protect the company's and the shareholders' interests. However, it only has a loosely defined monitoring role over the board of directors and managers.

Though being a part of two-tier board structure, the establishment of Chinese supervisory board shares no common social and philosophical considerations that underlay the supervisory board in German codetermination model of corporate governance. The supervisory board is small in size $\mathrm{e}^{26}$ and usually has labour union and major shareholder representation, which is a combination of the German-style supervisory committee and Chinese traditional concept of employees as masters of enterprises. In practice, because of the SOEs' traditional business practices, shareholders appoint only about half of the supervisors, but especially in the case of holders of legal person shares (SOEs), appoint significantly more chairs and vice chairs. Leaders of party committees tend to assume the positions of chair and vice chair in almost all listed companies. Unions are not represented on supervisory boards to any significant extent.

Supervisors generally meet less often than board of directors and their meetings are less well attended. Their published announcements indicate that they are rarely contest decisions made by boards of directors and company executives. The lower-quality and less

\footnotetext{
${ }^{25}$ The Code was issued in January 2002 and set forth the guidelines of good corporate governance that all listed companies in China must follow.

${ }^{26}$ The number of supervisors could be just one or two for small limited liability companies, for listed companies it is usually over three (Tam, 2002).
} 
professional experience of supervisors compared with directors and managers have led to supervisors' inability to actually supervise directors and managers (Tenev et al., 2002).

The supervisory board in China has so far not played any effective governance role (Tam, 2002). In their study, Dahya et al. (2002) find that in most of Chinese companies of their sample, the supervisory board is the board that does nothing or merely provides advice. Xiao et al. (2004a) attribute the less-than-desirable role played by the supervisory board to a number of causes, including strong influence of the Party/government, the inadequate legal prescriptions on the rights and liabilities of the supervisory board, the type of listing (domestic or foreign), the biased power relations between board of directors and the supervisory board, lack of independence, lack of technical expertise, perceived low status, information shortage and lacking of incentives.

\subsubsection{Independent directors}

In order to strengthen the independence of board of directors, upgrading directors' professional qualifications, as well as standardising the function of boards, the CSRC adopted the Guidelines for Establishing an Independent Board of Directors in Listed Companies in August 2001. The rules require that at least one-third of the board consist of independent directors, including at least one accounting professional. The independent directors are required to work for listed companies for not less than 15 working hours a year. Independent directors are encouraged to express the independent opinions of the major events occurred in the listed companies including nomination, appointment or replacement of directors, appointing or dismissing senior managers, remuneration for directors and senior managers, and events that the independent directors consider to be detrimental to the interest of minority shareholders.

Practices show that Chinese companies listed overseas have met the requirement by establishing the office of independent directors and introduced standard operational procedures for the system of independent directors. Many A-share companies listed at home have invited well-known social personages and professionals to be independent directors, who account for as high as 50 per cent of the board membership in quite a few companies. Statistics showed that 204 Chinese A-share companies had instituted the office of independent directors on the board of directors prior to the official introduction of the system of independent directors (Zhang, 2001). 
Under the Chinese context, most independent directors can hardly be considered truly independent (Fan et al., 2002). These people are not appointed through market decision, but, rather, through administrative decisions. The independent directors normally have close ties with a firm's owners (the state) or its senior managers. Long (2001) revealed that independent directors cannot really operate independently due to their various relationship with their listed companies, and they find it hard to play their role at a time when control by insiders and the presence of a single dominating shareholder are common problems in listed companies. A number of factors, including the lack of legal backing for the role of independent directors, the lack of incentives, drawbacks in the independent directors' own credentials and abilities, and the impact of the social and culture environment, affect the role of independent directors in listed Chinese companies (Lu, 2003).

\subsubsection{Managerial incentives}

In order to align managers' interests with those of shareholders, sufficient incentives must be provided for managers to carry out strategic directions laid down by a firm's board. Most listed companies in China lack an incentive mechanism that ties management's performance to its compensation (Shi and Weisert, 2002).

Market-based managerial incentives do not operate in the governmental public administration apparatus within which control and management of SOEs are exercised. In China, managerial market does not exist in the state sector and SOE managerial jobs are not contestable. The entire cascading structure of agents exercising property and control rights, from the head of state to the line ministries and local governments and down to the SOE manager, comprises government officials and bureaucrats on fixed and standardised public sector remunerations systems, which are either weakly or not correlated to the performance of SOEs under their control. Thus, neither so-called principals (the multi-tiered state controlling authorities of SOEs), nor enterprise management have adequate incentives to ensure the most efficient use of assets under their control.

However, the Chinese enterprises have extensively explored incentive mechanisms under existing laws. During the mid-1990's, some of them experimented the annual salary system for the managers. Later, some listed companies explored using equity-based compensation as an incentive. At present, listed companies adopt one of the four representative stock incentive programs that are still under test: (1) paying stock as bonus; (2) paying bonus 
based on stock price. For example, management's bonus is paid based on the product of the number of phantom shares rewarded and the share's market price; (3) paying bonus based on net profits. For example, the company can set up a rewarding fund for directors, senior management, and other people with significant contributions. The source of the fund comes from companies' net profit. It can only be used to buy shares for those to be rewarded and the shares may not be accessed until a later time; (4) requiring the buy-and-hold of a certain number of shares, for example, the senior management may be required to hold a certain number of the company's public shares.

Western literature has documented sufficient support for positive relationships between managerial incentives and firm performance (e.g., Coles et al., 2001). However, in China, the level of compensation for senior managers is mostly determined by the state, which follows the salary structure of government officials. In addition, the new incentive mechanisms are still under test, and the current level of compensation in terms of both salary and shareholdings are not disclosed in the public reports. Hence, a relationship between senior managers' compensation packages and firm performance in Chinese firms is dubious (Fan et al., 2002).

\subsection{External corporate governance mechanisms}

\subsubsection{Market for corporate control}

The market for corporate control is a vital element of a competitive commercial environment, and one that helps to enhance corporate governance. However, due to the prevalence of ownership concentration in Chinese stock market and the fact that the state is the main majority shareholder, it is very hard for takeovers (especially hostile takeovers) to succeed in China. Fan et al. (2002) argue that the market for corporate control is at its most primitive stage, as most mergers and acquisitions are policy-driven and managed by state. Such administrative maneuvering may only transfer the burden to those profit-making enterprises without solving the fundamental problems. In practice, many local authorities require healthy SOEs to merge with as many as loss-making ones as possible to make their own performance look good on paper. It is thus not surprising that many mergers have mainly led to changes in names rather than the needed restructuring. Therefore, China will not have an active market for corporate control until more non-state controlled enterprises are listed in the stock exchanges (Tam, 2002). 


\subsubsection{Managerial labour market}

Because most of the larger firms are state owned, the managerial labour market in China is far from being mature. The role of competitive market for managerial manpower to complement the function of an active market for corporate control is not yet available in China. For listed companies with the state as a majority shareholder, the pool of appointment to the positions of chief executive, most senior managers and a high proportion of the directors on the company board is restricted and subject to government influence or direct intervention (Tam, 1999).

Recent reforms of SOEs strengthened a nascent managerial labour market by incorporating incentives suggestive of competitive Western labour markets. Poorly performing firms were more likely to have a new manager selected by auction, to be required to post a higher security deposit, and to be subject to more frequent review of the manager's contract. Managers could be, and were fired for poor performance. Managerial pay was linked to the firm's sales and profits, and reform strengthened the profit link and weakened the sales link. Thus, the economic reforms helped develop an improved system of managerial resource allocation responsive to market forces.

\subsubsection{Legal protection of investors}

Investor (minority shareholder) rights are poorly protected in China. Based on the widely used LLSV indicators of investor protection developed by La Porta et al. (1998), Pistor and $\mathrm{Xu}$ (2004) calculate an index score of 3 for China, as compared to the average score of 3.61 for all other transition economies. MacNeil (2002) gets an index score of 2 for China as compared with a world average of 3 , suggesting that China fall into the investor-unfriendly category of countries.

The market-oriented legal system, in particular, the Corporate and Securities law framework, have only been developed over the past two decades in China and is still relatively rudimentary and untested in many aspects. Shareholders' meetings are a corporation's most powerful authority; however, Company Law and relevant regulations do not specify shareholders' rights clearly. The power to elect and remove directors is one of the indirect methods whereby shareholders can influence a company's behaviour, but Chinese minority shareholders have limited capacity to ensure that they are represented on 
the board. Reportedly, a small number of listed companies have tried the cumulative system; however, the lack of enabling regulations limits its applicability to listed companies. MacNeil (2002) states that lawmakers were primarily concerned with protecting State control over listed companies in drafting the Company and Securities Law in China.

Moreover, Chinese Criminal Law, Company Law, and Securities Law neglect civil liability and compensation, and have not provided a procedure and specific clauses for enforceable civil actions ( $\mathrm{Lu}, 2003)$. Meanwhile, courts have a long tradition of protecting State interests and have very little experience with private plaintiff-driven litigation. Pistor and $\mathrm{Xu}$ (2004) point out that public law enforcement in the form of fines or other sanctions imposed by a regulator has been very weak, and equally, private enforcement of investor rights have virtually been absent in China so far, not because of a lack of demand for them, but because courts have restricted investor law (Chen, 2003). Lin (2001) attributes the difficulties faced by Chinese shareholders in seeking legal recourse to such three factors as the high cost of lawsuit, weak self-protection awareness of minority shareholders, and the reluctance of local People's Courts to accept cases concerned with what it regards as a company's internal dispute.

In addition, in China, minority shareholders and other stakeholders are often regarded not as fellow stakeholders with equal rights and interests to be respected and protected, but as speculators expecting to free ride on the company's performance (Lin, 2001). These outsiders are expected to be passive and not to "interfere" in the company's "internal affairs" (its governance), so expropriation of minority shareholders by controlling shareholders is extensive. Under the insider system, minority shareholders' rights are easily expropriated through various methods, "in some instances, the insiders simply steal the profits. In other instances, the insiders sell the output and the assets. In still other instances, expropriation takes the forms of diversion of corporate opportunities from the firm, installing possibly unqualified family members in managerial positions" (La Porta et al., 2000, p4).

Berkman et al. (2005) examine the wealth effects of regulatory changes intended to improve corporate governance by protecting minority shareholders from expropriation by controlling shareholders. They find positive and significant increases in shareholder wealth 
with the improvement of investor protection, primarily accruing to firms with weak governance. Their results provide evidence supporting the theoretical model of La Porta et al. (2002), which predicts that better investor protection is rewarded with higher firm valuation.

\subsubsection{The role of the government/party}

China is a transitional economy still tightly controlled by the Party/government (Xiao et al., 2004a). The state had played multiple and conflicting roles in a SOE, and was the owner, supervisor, manager, and creditor of an enterprise at the same time. Moreover, the state exercised macroeconomic functions, including social, regulatory, and policy making functions on one hand, and engaged itself in microeconomic activities on the other. These two roles are inherently conflicting. The macroeconomic role required the state to concern itself with overall economic performance of all enterprises, while the microeconomic role required the state to concern itself only with the performance and economic efficiency of a particular enterprise. It was essential to break such an integration of conflicting roles, as the government's dual roles can lead to conflicting goals in dealing with Chinese firms, which in turn weakens the effectiveness of both of its roles (Allen et al., 2005).

To develop a 'socialist market economy', a great deal of efforts has been denoted to separate the responsibilities between the government and the Party and to clarify the relationship between government and enterprises. In late 1998 the government ordered all party and government administrative organs to sever their links with the enterprises they control (World Bank, 1999).

Chinese companies, however, are still under the political control from the Party/government. In China, rampant government interventions are well known (the Shanghai Stock Exchange, 2000; Tam, 2002). First, SOEs are still largely state-owned or controlled, and the state is insistent on retaining controlling shares in strategic sectors of the economy after listing companies. Working on the assumption that listed companies are actually controlled by their large shareholders, Tian (2001) calculates that the government control 44 per cent of listed Chinese companies. State shareholding enables the government to remain involved in, and often even to dominate, companies' decision-making. Second, the government and ministries have maintained some control over listed Chinese companies. According to Shanghai Stock Exchange, about 56 per cent of listed companies 
still maintain formal ties with administration and ministries (Hu, 2000). Third, local party committees survive as a source of political control (OECD, 2002; Opper et al., 2002; Qian, 2002). As local party committees have historically been involved in the decision of all firms in China, path-dependency (North, 1990) would predict that local party committees would remain involved in a broad range of firm decisions. Moreover, government representation on the board of directors constitutes a source of additional political interference in the companies (Chang and Wong, 2002).

As Chinese economic reform proceeded under the central leadership of the Chinese Communist Party and the government, government/party control in listed Chinese companies is important. However, empirical studies indicate that government interference has a negative impact on firm performance (e.g., Chen, 2001; Sun and Tong, 2003). From their survey, Wong et al. (2004) conclude that government/party control is detrimental to firm performance.

Based on the detailed database tracking CEOs and directors of 617 companies that went public in China during 1993 through 2000, Chen et al. (2004) report that 28 per cent of the companies' CEOs are politically connected- they are current or ex-government bureaucrats. Controlling for other factors that influence firm performance, they also find that the postIPO long-term stock returns of a firm is significantly worse when its CEO is politically connected, consistently, accounting performance of a firm run by a political-connected CEO deteriorates more than an otherwise similar firm.

Chang and Wong (2004) offer evidence that the existing level of party control is excessive, and that reducing the overall level of local party committees' decision-making power would improve the performance of listed Chinese companies.

\subsubsection{External auditing}

Since the promulgation of the Securities Law, auditors have been empowered to review the company's financial statements and records, and to request the company's management all relevant information as they consider appropriate. The primary objective of external auditing is to ensure a fair presentation of financial statements, and an audit engagement should also include detecting, preventing, or stopping fraud, inefficiencies, or irregularities in clients' operation (Lin and Chen, 2004). 
It is well known that false accounting and financial misreporting are pervasive among Chinese companies. National Audit Office stated in December 1998 that "cooked books," embezzlement, fraud, and "irregularities" in financial management were widespread among Chinese firms. This has created an environment in which external auditor could perform an important role in corporate governance in China. Certified public accountants (CPAs) and their firms in China were historically affiliated with the government finance bureau, thereby seriously impairing their independence and clouding risk management concepts. In order to rectify these shortcomings, the CSRC and the Ministry of Finance (MOF) started in 1993 to require CPA firms to be separate and independent from their former bosses, i.e., finance bureau or other governmental agencies, and to obtain licenses to provide independence audits and related services, as well as to improve the quality of information disclosed by companies.

However, it is apparent that auditing practice in China requires significant improvement (Cooper et al., 2002). A number of major financial scandals erupted and exposed publicly the ethical and quality problems that had existed in accounting and audit firms for some time (Xiao et al., 2000). Chinese CPA firms have many problems in their operations because of lack of sound supervision mechanisms, which gives rise to serious fraud cases in the securities market. Many Chinese CPA firms do not have enough knowledge about international practices and are not well equipped with computer skills, due to a lack of proper training (Lin, 2004).

\subsection{Financial institutions in China}

Financial institutions in China today include commercial banks, pension funds, insurance companies, securities investment funds, securities companies, trust and investment companies and underground funds. The Chinese institutional landscape is characterised by blurred boundaries among different institutions and their activities; an insufficient legal base; varied (and sometimes competing) regulatory agencies; and jurisdictional uncertainties by institutions (Kim et al., 2003).

\subsubsection{Commercial banks}

Chinese banking system has three tiers. The first tier is the People's Bank of China (PBOC). Under the guidance of the State Council, the PBOC formulates and implements monetary 
policy, prevents and resolves financial risks, and safeguards financial stability. The secondary tier is the China Banking Regulatory Commission (CBRC), which is a management organ to authorise the establishment, changes, termination and business scope of the banking institutions, as well as to take enforcement actions against rule-breaking behaviours. The third tier is the bank-financial institutions, including commercial banks and other banks. ${ }^{27}$

Established in 1978, Chinese commercial banking system now includes five tiers, according to the PBOC. The four state commercial banks-Industrial and Commercial Bank of China, Bank of China, China Construction Bank, and Agriculture Bank of Chinaare the dominant players in Chinese financial sector, accounting for 53.6 per cent of total bank assets and 53.5 per cent of total local currency loans. ${ }^{28}$ Second-tier shareholding commercial banks ${ }^{29}$ are much smaller than state commercial banks. Many of these banks, however, are more profit-oriented with better management. Two housing banks belong to the second tier. ${ }^{30}$ The third-tier urban commercial banks are emerging as innovative players in banking. The forth tier is rural credit cooperatives, and the final tier includes foreign banks.

Banks are tightly restricted in their ability to offer clients anything other than deposits, nontradable government savings certificates or, marketable government bonds. ${ }^{31}$ While banks can and do distribute, on an as-agent basis, insurance policies and investment funds produced and underwritten by other non-bank institutions, they are specially prohibited from engaging in the securities business or owning or investing in non-bank financial institutions. The PRC Commercial Banking Law of 1995 (Article 43) states that a commercial bank shall not engage in trust investment or stock business; any investment in non-bank financial institutions or enterprises is also prohibited. The Securities Law of 1998 (Article 6) similarly states that securities companies must be established separately from banks, trust companies and insurance companies. The Insurance Law of 1999 (Article 104)

\footnotetext{
${ }^{27}$ Other banks are the three policy banks including China Development Bank, the Export-Import Bank of China, the Agricultural Development of China.

${ }^{28}$ As at December 2004: the official website of the China Banking Regulatory Commission.

${ }^{29}$ Important banks in this tier include Bank of Communications, China Merchants Bank, Guangdong Development Bank, Shanghai Pudong Development Bank, Shenzhen Development Bank, China Everbright Bank, and China Minsheng Bank (nation's first private bank).

${ }^{30}$ The two housing banks are Yantai Housing Bank in Shandong Province and Bangbu Housing Bank in Anhui Province.

${ }^{31}$ Beginning in June 2002, selected large commercial banks were allowed to have over-the-counter bond dealings with individuals and corporations, holding custodian accounts for them. In the past, the lack of a subdepository system impeded banks' ability to trade bonds with retail investors.
} 
states that insurance companies are not allowed to use their funds to set up institutions dealing in securities or invest in enterprises. Prior to this ban, which is contained in the Commercial Bank Law of 1995, the four largest state-owned banks had involved themselves in non-banking activities, including the securities business. Following the separation of banking from non-banking, the PBOC required banks to gradually shed their ownership of non-bank financial institutions. The separation principle refers to banks being permitted to offer only non-bank financial products produced and managed by others. Banks thus cannot design, produce, market and manage products that they regard as appropriate for their own customers and that their own customers will trust as a result of the bank's reputation.

Although banks have played a dominant role in collecting and mobilising public saving, their role in deploying those savings and advising their customers has been limited, both by the Law and by the burden of lending to SOEs at interest rates that are low and undifferentiated by assessments of credit risk.

Commercial banks are the key investors of government and quasi-government securities. Depending on the size of their foreign currency deposits (that is growing with surge in foreign reserves), the four state-owned commercial banks and the larger commercial banks also invest in foreign bonds on their own accounts as well as on behalf of clients. With emergence of securities investment funds, commercial banks started to develop their custody business as a new source of fee-based income. The market is dominated by the four state-owned commercial banks, Bank of Communications, China Everbright Bank, China Merchants Bank, and Shanghai Pudong Development Bank.

So far, China Merchants Bank, Shanghai Pudong Development Bank, Shenzhen Development Bank and China Minsheng Bank have been listed on the stock markets, and they are enjoying more and more market shares.

However, compared with those in developed economies, especially in the UK and US, Chinese commercial banks are still very weak with poor asset quality, low profitability, and low productivity (China Finance Yearbook, 2004). Low efficiency of commercial banks can be attributed to extensive operation, loads of policy loan, high debt ratio, poor protection of creditors' right, and unfair competition (Zhu et al., 2002). 


\subsubsection{Securities companies}

Chinese security industry has become one of the important sectors in security market. As of December 2003, 133 securities companies were operating in China, and they fell into four categories: comprehensive, broking, rectifying, and transitional. According to the Securities Law of 1998 (Article 6), securities companies must be established separately from banks, trust companies and insurance companies. ${ }^{32}$ Further, financial institutions, with the exception of securities companies and trust and investment companies, are not permitted to hold shares in securities companies. ${ }^{33}$

According to Zhu et al. (2002), the development of securities companies can be divided into three stages. The first stage is from 1987 to 1989, in which securities companies were small in scale and their business was simplistic. At the end of 1989, there were only 30 companies with about 5 billion yuan of total assets. From 1990 to 1995, securities companies developed quickly in both number and scale. By the end of 1995, 97 securities companies were operating with 83.2 billion yuan of total assets, which was more 16 times of that in 1989. The third stage started from 1996, the competition became sharper, and securities companies restructured through mergers and acquisitions. As a result, the number dropped while the scale in assets increased greatly. However, after a short boom in 2000 , when the bullish run of the bourses pulled up brokering and underwriting income and then overall profitability, securities companies began their downhill journey afterwards.

Since 2001, the operating environment of securities industry has been getting worse. On the one hand, the turnover dropped dramatically. Table 5.1 tells that from 1998 to 2003, the turnover reached its summit in 2000 with 6.1 trillion yuan, and increased by 94.21 per cent compared with 1999 . However, after 2000, it dropped dramatically by 37.03 per cent and 26.93 per cent in 2001 and 2002 respectively. Although in 2003, the situation improved, and the turnover increased by 14.74 per cent compared with 2002, influencing by the downward adjustment of commission, revenue from brokerage still dropped. Meanwhile, with the dramatic decrease in turnover, the funds raised from stock markets decrease greatly from 2001 as well, and the revenue from investment banking were greatly affected. In 2003, 122 of 133 securities companies reported a total of more than 900 million yuan

\footnotetext{
${ }^{32}$ Prior to the effective date of the Securities Law of 1999, Trust and investment Companies (TICs) were permitted to engage in securities brokerage business. The Securities Law of 1999 required TICs to separate their securities business.

33 "Certain Options on Future Strengthening the Administration of Securities Companies" (CSRC, 1999).
} 
(US\$ 109 million) in losses, and their assets shrank. A number of companies have also been exposed as misbehaving for years, such as embezzling the guarantee funds of clients or irregular investment practices, leaving huge liabilities (China Daily, $4^{\text {th }}$ February 2004).

\section{Table 5.1 Statistics of share turnover from 1998 to 2003}

This table presents the statistics of share turnover in the period of 1998-2003. Source: China Securities and Futures Yearbook 2004.

\begin{tabular}{lcccccc}
\hline Year & 1998 & 1999 & 2000 & 2001 & 2002 & 2003 \\
\hline Turnover (10 million) & $23,527.31$ & $31,319.6$ & $60,826.65$ & $38,305.18$ & $27,990.46$ & $32,115.27$ \\
\hline & & & & & & \\
Increased percentage & & $33.12 \%$ & $94.21 \%$ & $-37.03 \%$ & $-26.93 \%$ & $14.74 \%$ \\
\hline
\end{tabular}

Securities companies have a narrow business scope in China, focusing on brokerage of and dealing in equities. Revenues from their investment banking business only account for a marginal proportion. Research on Chinese securities industry by China International Capital Corporation Ltd. (16 $6^{\text {th }}$ July 2001) showed that a typical one of Chinese top ten securities companies earned most its revenues from brokerage (44 per cent) and securities trading (38 per cent) in 2000 . In probability terms, strict entry barriers, coupled with rapid market expansion, guaranteed monopolistic rents to incumbents. However, concentrated revenue sources imply that profits are highly subject to market conditions.

Most securities companies are shareholding companies or limited corporations. However, they remain state-controlled, albeit with varying degrees, in the sense that the government is still one of the major shareholders. While performing better than the SOEs in other industries in terms of market orientation, productivity, incentive, and profitability, they still bear a print of SOEs with weak corporate governance, abuse of power, loose financial discipline and other SOEs problems. As regards to business performance, securities companies still lack justified business innovations, as reflected in the duplications of business for all the securities companies, on the one hand, and show unjustified aggressiveness resulting in market irregularities, on the other. They have played an important role in the "bankers" market manipulation, and are also involved in illegally financing big investors, misusing investors' deposit, and buying and selling without funding through securities repurchase business, etc (Business Intelligence, 2001). 


\subsubsection{Securities investment funds}

Securities investment funds and fund management companies (FMCs) have a short history in China, and hence are an immature while emerging sector. The development of securities fund industry is normally divided into two stages. Before 1997, supervised by the People's Bank of China (PBOC), investment funds were very few in numbers and small in scale. After the issuance of the Tentative Regulation of Securities Investment Funds in 1997, the CSRC became the supervisory body of fund industry, and investment funds began their new normal way.

According to current regulations, FMCs are prohibited from offering discretionary management services to individuals, although they may be permitted to manage segregated pension assets in the future. The regulations limit investment funds to invest no more than 10 per cent of its total funds in one listed company, and its holdings of that company should not exceed 10 per cent of that company's total shares.

Although with short history, this industry keeps a quick and stable development, especially after September 2001, when the first open-end fund was introduced (China Economic Times, $20^{\text {th }}$ August 2002). By the end of 2003, 54 closed-end and 41 open-end investment funds have been established by 34 FMCs. New offerings of open-end funds amounted to RMB 67.8 billion yuan, compared with RMB 44.8 in 2002 and 11.7 in 2001 respectively. ${ }^{34}$ Closed-end funds dominated the market with a 50.6 per cent share in 2003, down from 58 per cent in 2002 and 85 per cent in 2001, the nascent open-end funds sector, which is expected to become the most popular form in the future, had 49.4 per cent of market size by end 2003. It is reported that the net asset of securities investment funds accounted for nearly 25 per cent and the assets invested on shares had 13 per cent of total negotiable market capitalisation in the two stock exchanges by the end of 2004 (Securities Daily, $4^{\text {th }}$ January 2005). It is self-evident that investment funds are more and more influential in the security market.

However, such securities investment funds still represent a relatively insignificant part of the savings spectrum, with aggregate funds under management of RMB 161.5 billion (1.38 per cent of GDP) by the end of 2003. Of this amount, closed-end and open-end funds stood at RMB 81.7 billion and RMB 79.8 billion respectively.

\footnotetext{
${ }^{34}$ Data are from China Securities and Futures Statistical Yearbook 2004.
} 
As investment funds are created based on contractual relationships among a fund management company, a fund custodian, and investors, that is, they are not independent entities. Under the Investment Fund Law, ${ }^{35}$ only fund management companies (FMCs) approved by the CSRC, may establish and manage investment funds. Commercial banks that are licensed by the CSRC may act as fund custodians, and they also assume the task of monitoring the investment activities of fund managers. For example, a custodian must refuse to execute a fund manager's investment instructions that violate the law or the terms of a fund contract, and must report such instances to the CSRC. Liu (2004) argues that this relationship makes it difficult for both individual and institutional investors to check and control fund management companies.

Because of the short history of investment funds, FMCs have the same problems with most listed companies in corporate governance (Yuan and Ruan, 2003), and they are reportedly prone to irregularities, including collusion and share-price manipulation. In January 2002, the CSRC criticised some fund managers for misconduct in their IPO application process. However, since 2001 investment funds prefer value investment, their operation tends to be transparent.

If investment funds are to become mainstream savings vehicles for ordinary retail investors, as they are in many countries, it is imperative that the image of the industry be clean and honest (Kim et al., 2003). According to Ou (2001), to establish an effective corporate governance system of investment funds, relevant regulations should be strengthened and improved to standardise the practice of fund managers and protect the funds assets. The passage of the Securities Investment Funds Law in October 2003, with relevant coordinated regulations ${ }^{36}$ provides a solid basis to develop this industry. Further, an effective managerial labour market should be promoted to select fund managers. When the incumbent fund manager does not perform satisfactorily, his position should be replaced by new managers, or individual investors vote with their feet by means of redeeming their funds. In addition, since the portfolio management fee is a fixed percentage of the assets managed, which is not linked to performance, it appears that fund managers have no incentive to outperform the market. Thus, performance-oriented compensating schemes need to be set up to ensure that fund managers act in the best interest of shareholders.

\footnotetext{
${ }^{35}$ The Securities Investment Funds Law was issued in October 2003.

${ }^{36}$ Such cooperative regulations are as "Administrative Regulations on Information Disclosure of Securities Investment funds," "Administration Regulations on the Operation of Securities Investment Funds."
} 


\subsubsection{Trust and investment companies}

Trust and Investment Companies (TICs) were guided and supervised by the People's Bank of China (PBOC) before March 2003, when the China Banking Regulatory Commission (CBRC) was established, which signalled that the function of monitoring financial institutions was now separated from the central bank.

Trust and investment companies (TICs) were one of the most important sectors in Chinese capital markets in the two decades after 1979, when the State Council first established the China International Trust and Investment Corporation (CITIC). By the late 1980s, some 700 TICs were established by ministries, municipalities, provinces, and large SOEs, first as a vehicle to attract foreign capital, but later as an omnibus financial arm of public organisations. They were viewed as "extension departments" of their sponsors to handle a variety of activities, including project management, the issuing of securities, consultancy, and leasing (Dipchand et al., 1994). Until the mid-1990s, given their universal business scope, flexible fund-raising capability, and minimal supervision, TICs were highly regarded financial institutions, dominating the Chinese non-bank financial sector even though their business scope involved quasi-banking.

The TICs sector began to encounter difficulties in 1993, when the central government began to restrain the overheating economy, which produced slower output growth, tighter liquidity condition, and high inflation rates. In January 1997, the second largest TIC, China Agribusiness Development Trust and Investment Corporation, filed for bankruptcy. Thereafter, several TICs began defaulting on loans, leading to operation closures. The Asian financial crisis further aggravated the TIC sector, and some international TICs began defaulting on their foreign debt. What soon resulted was the TICs sector becoming one of the weakest links in Chinese financial system.

After 1999, the central government immersed itself into restructuring the TIC sector as TICs became a potential source of instability for the macro-economy. According to the 1999 rectification plan, ${ }^{37}$ TICs have been undergoing a long period of restructuring,

\footnotetext{
${ }^{37}$ The rectification plan included: (1) TICs should be restructured to become "intermediary financial institutions" which practice trust business. TICs would not be allowed to engage in banking business. (2) The trust and investment business would be segregated from the securities business in terms of structure, regulation and operation. (3) TICs should meet strict standards such as minimum capital. Small, undercapitalised TICs would be consolidated or closed.
} 
involving closure, liquidation, reorganisation, merger, and acquisition. During this process, some important laws and regulations were enacted. At present, China has put in place the framework of a complete set of laws and regulations on trust businesses, such as the Trust Law, which became effective on 1 October 2001, and the Administrative Rules on Management of Trust and Investment Companies, which came into effect on $12^{\text {th }}$ January 2001 , and was subsequently renewed on $9^{\text {th }}$ May 2002.

In sum, Chinese TICs sector remains in a state of flux. Notably, the restructuring process is thwarted by a combination of complex ownership, heavy debt burden and the need to negotiate loss-sharing agreements among domestic and foreign investors and creditors under their complicated financial structures. Because the serial collapse of large TICs revealed many abusive and imprudent practices, the sector will need time to rebuild public confidence. At the same time, the sector also faces increasing competition from securities and fund management companies as the divide between investment advisory, fund management and trust businesses become blurry. Furthermore, as these institutions are supervised by different regulators, there also exists room for regulatory arbitrage. Other impeding factors for sector growth include Chinese weak credit culture, unclear registration guideline for trust properties, and weak information disclosure, accounting and tax provisions. However, as long as the trust business is exclusively set aside for this sector, revamped TICs could have their chapter in Chinese capital market in the future.

\subsubsection{Insurance companies}

As of end-2003, 44 insurance companies were licensed, 41 foreign companies operated through joint ventures or branch operations, and combined assets of insurers stood at RMB 912 billion yuan (7.8 per cent of GDP), making the insurance sector by far the largest financial institution in China. In 2003, the total premium income aggregated RMB 388 billion yuan (life: RMB 301 billion, non-life: RMB 87 billion), up 27.2 per cent over $2002 .^{38}$

Under the "Provisional Regulations on Investment in Insurance Companies" issued by the China Insurance Regulatory Commission (CIRC) in 1999, 'banks' and 'securities

\footnotetext{
${ }^{38}$ The official website of the China Insurance Regulatory Commission, http://www.circ.gov.cn.
} 
institutions' are excluded from the definition of qualified shareholders, "unless the relevant laws or regulations have otherwise stipulated or have gained the State Council's approval." Currently there has been some relaxing of the strict rules governing investment by insurance companies. "Regulations for the Administration of Insurance Companies" which was effective in March 2000, have been used by the CIRC to liberalise investment restrictions to a limited extent. The following relaxations have occurred: (1) In 1999 the CIRC permitted insurance companies to invest 5 per cent of their assets, and later up to 10 per cent, in investment funds, investing largely in equities. This investment limit was raised in January 2001 to 15 per cent for a selected group of 6 insurance companies and 12 per cent for 2 others. (2) Plans for licensing special investment funds whose investors are limited to insurance companies; rather, those permitted would be asset management companies licensed by the CSRC. (3) In June 2001, insurance companies were allowed experimentally to establish in-house asset management capacity. (4) Permitted investments are expanded to include bank deposits, government bonds, financial debentures, corporate bonds, securities investment funds and repos. (5) In October 2002, certain investment related negative clauses of the "Regulations for the Administration of Insurance Companies" were amended. (6) In November 2002, the CIRC abolished the verification or pre-approval requirement for 58 corporate actions, including those pertaining to investments in securities investment funds, purchases of corporate bonds and overseas deployment of funds.

On $25^{\text {th }}$ October 2004, the CIRC and CSRC jointly released a regulation that allows insurance firms to invest 5 per cent of their assets directly in Chinese stocks and bonds. Previously, insurers were limited to investing in domestic stocks and bonds through investment funds, in which they could put up to 15 per cent of their assets. Insurers will be prohibited, however, from investing in any company whose share price has doubled over the previous year. The 5 per cent ceiling would free-up about US\$7billion in assets for investments, which could help boost Chinese flagging domestic stock markets, as well as yielding the higher returns for insurers.

Insurance companies are important "collectors" of funds in the capital market (Dipchand et al., 1994). With the further liberalisation of investment restrictions and product innovation, insurance companies' role in the development of capital markets in China will be potentially significant. 


\subsubsection{Pension funds}

Pension funds, which are among the most important financial institutions in mature market economies, have existed in China since the late 1980s.

Until the late 1980s, an urban- and state-owned enterprises-based pay-as-you-go (PAYG) system provided a generous pension, i.e., 80 per cent of a worker's total salary in addition to health, housing and basic welfare support (so-called "iron rice bowl"). A shift to a market economy rendered many SOEs, facing increasing competition from the private sector, unable to pay their retirees the promised full pension benefits. More fundamentally, demographic change has made the pension obligations-whosoever should bear suchvery costly to fulfil.

That demographic problem combined with the inability of SOEs to cover the pension of current retirees makes the reform of the PAYG system a top priority. The state council has issued a number of decrees calling for moving to a multi-pillar system, incorporating both a defined benefit PAYG plan and a defined contribution plan with fully funded individual accounts, but little progress has been made (Wang et al., 2004b).

One of recent initiatives for Chinese pension reform is the creation of the National Social Security Fund (NSSF) ${ }^{39}$ in September 2000. The NSSF is being built up as a reserve fund to cover potential unfounded liabilities in the PAYG system resulting from an aging population and an increasing dependency ratio. The fund's first capital market investment was subscription of Sinopec's A-shares as a strategic investor in August 2001. Since its inception, the NSSF has grown to a value of RMB 154 billion yuan (1.32 per cent of GDP) in December 2003.

Under the "Provisional Regulations on the Management of Investment by Social Security Fund," which was issued in December 2001, the NSSF can invest in bank deposits, government bonds and other liquid financial instruments including securities investment funds, equities, and corporate and financial policy bonds. Although these new Regulations would permit up to 40 per cent of the NSSF's assets to be invested in equities, the NSSF

\footnotetext{
${ }^{39}$ The NSSF is a public agency under the State Council and is primarily supervised by the MOF.
} 
Council $^{40}$ opted out of portfolio equity investment, due to the volatility of the stock market and to the low share quality of some of its listed companies. Finally, in January 2003, the Council awarded 11 equities and fixed income portfolio management mandates to six qualified $^{41}$ domestic fund managers. This decision marked the historical beginning of pension fund participation in the stock market to anchor the otherwise highly speculative and short-term oriented market. At the end of 2003, the total asset of pension funds was 324 billion yuan (2.77 per cent of GDP). ${ }^{42}$

\subsubsection{Underground funds}

The underground funds, ${ }^{43}$ or privately placed funds, have proliferated in China since the introduction of stock exchange in the early 1990s. They exist since other means by which larger investors can obtain professional discretionary management have not been freely available, and because of the rigid, bureaucratic and expensive licensing regime (Kim et al., 2003).

It is estimated that the total value of assets may be as high as RMB 700 billion yuan, or 6.0 per cent GDP (compared to RMB 161.5 billion yuan and 1.38 per cent of 2003 GDP for licensed securities investment funds) (Shenzhen Business News, 2004). The main client base of underground funds consists of wealthy enterprises and financial institutions, such as investment consulting companies, investment management companies, financial management companies, and financial consulting companies (Xia, 2001).

The passage of the Trust Law in 2001 has provided the opportunity to formalise these activities, however. The "Administrative Rules on Management of Trust and Investment Companies" requires all companies with business operations falling under this law to be

\footnotetext{
${ }^{40}$ The Council of the NSSF, which includes the finance vice-minister as an ex-officio member, is the highest decision making body of the Fund.

${ }^{41}$ Fund management companies or other institutional investors are qualified if they (a) meet minimum paid-in capital requirements (RMB 50 million for a fund management company but not yet decided for other institutional investors); (b) have minimum two years' experience in securities investment; (3) demonstrate good corporate governance; (d) have no records of severe irregularities; (e) have sound internal management; and (f) have control systems and qualified staff for investment business.

${ }^{42}$ The official website of the Ministry of Labour and Social Security (MOLSS), http://www.molss.gov.cn.

${ }^{43}$ Large existing underground funds are basically devoted to equity speculation and not productive investment. Underground funds encourage enterprises to use their spare cash and often borrowed from stateowned banks for speculation. In this sense, this sector is distinguished from informal credit sector characterised as breaking through rigid monetary control and providing finance for growth of private enterprises in China, particularly in prosperous coastal regions.
} 
registered. In addition, starting from 2003, securities companies that have acquired a special license may manage discretionary funds on client's behalf.

It is likely that a clearer definition of mainstream asset management and the ability of licensed entities to offer comparable portfolio management services will eventually transform unlicensed funds into legitimate undertakings.

\subsubsection{The characteristics of financial institutions}

In general, Chinese financial institutions have the main characteristics as follows, which differentiate them from those in developed economies.

First, restricted by the short history of financial institutions and the overall characteristics of Chinese securities market, Chinese financial institutions account for very small percentage in the market capitalisation and the number of shares. Given the largely unfounded pension system (2.77 per cent of GDP), fledgling collective investment funds (1.38 per cent of GDP), and insurance funds (7.80 per cent of GDP), Chinese formal institutional assets register 11.95 per cent of GDP at the end of 2003. In addition to this formal financial institution base, large sums are believed to be managed privately by securities companies, TICs, and unlicensed entities. Should privately placed funds be included (6.00 per cent of GDP), total institutional assets might be around 17.95 per cent of GDP.

Second, because of their small market presence and limited power, financial institutions are just the agents to make money for their principals, rather than owners of corporations (Zhang, 2002). In order to earn stable and regular dividend income, they prefer to invest in companies with good performance. They do not hold the shares over a long period of time, and sell them when they are not satisfied with their portfolio companies. In this respect, they are short-term traders on the capital market.

Third, as most Chinese financial institutions are born out of state-owned companies (Zhu et al., 2002), state ownership is highly concentrated in these companies, large shareholders always control management and affect the rights of minority shareholders. Currently, many financial institutions suffer the same problems as listed companies, including insufficient internal control and entanglement of the interests of controlling shareholders and those of 
the shareholders and investors (Cha, 2001).

Finally, China has a restrictive system of investment options for financial institutions. Typically, different investor groups are subject to different investment restrictions. The list of permissible investment often contains limited options vis-à-vis international practices, which restricts financial institutions' ability to manage diverse and balanced portfolios. Table 5.2 summarises permissible investment products by type of institutions. Despite continuous efforts by regulators to relax and codify investment restrictions, the current system expressly prohibits investments that are permitted in other markets. It is argued that the restrictions result in sub-optimal allocation of resources (Duggal and Millar, 1999).

\section{Table 5.2 Investment restrictions in China at a glance}

This table provides an overview of investment restrictions in China. Source: Kim et al. (2003).

\begin{tabular}{|c|c|c|}
\hline Institutions & Permitted & Prohibited \\
\hline Banks & $\begin{array}{l}\text { Loans } \\
\text { Government Bonds } \\
\text { Discounting Bills } \\
\text { Inter-bank Call Loans } \\
\text { Corporate Bonds }\end{array}$ & $\begin{array}{l}\text { Equities } \\
\text { Investment Funds } \\
\text { Real Estate }\end{array}$ \\
\hline Investment Funds & $\begin{array}{l}\text { Equities } \\
\text { Government Bonds } \\
\text { Corporate Bonds } \\
\text { Cash } \\
\text { Bank Deposits } \\
\end{array}$ & $\begin{array}{l}\text { Investment Funds (Cross- } \\
\text { Investment) } \\
\text { Real Estate }\end{array}$ \\
\hline Insurance Companies & $\begin{array}{l}\text { Bank Deposits } \\
\text { Corporate Bonds (with limitation) } \\
\text { Investment Funds (with limitations) }\end{array}$ & $\begin{array}{l}\text { Equities } \\
\text { Real Estate } \\
\text { Loans } \\
\end{array}$ \\
\hline $\begin{array}{l}\text { National Social Security } \\
\text { Fund }\end{array}$ & $\begin{array}{l}\text { Bank Deposits } \\
\text { Government Bonds } \\
\text { Corporate Bonds } \\
\text { Investment Funds } \\
\text { Equities } \\
\text { Bank Deposits }\end{array}$ & Real Estate \\
\hline $\begin{array}{l}\text { Locally Controlled } \\
\text { Pension Funds }\end{array}$ & $\begin{array}{l}\text { Government Bonds } \\
\text { Bank Deposits }\end{array}$ & $\begin{array}{l}\text { Equities } \\
\text { Investment Funds } \\
\text { Real Estate } \\
\end{array}$ \\
\hline $\begin{array}{l}\text { Trust and Investment } \\
\text { Companies }\end{array}$ & $\begin{array}{l}\text { Equities } \\
\text { Government Bonds } \\
\text { Corporate Bonds } \\
\text { Investment Funds } \\
\text { Real Estate }\end{array}$ & \\
\hline
\end{tabular}




\subsection{The role of financial institutions in corporate governance in China}

\subsubsection{An overview of the role of financial institutions in corporate governance}

In January 2002, the CSRC introduced the "Code of Corporate Governance for Listed Companies in China" to standardise the operation of listed companies. In this Code, financial institutions are encouraged to play a role in the appointment of company directors, the compensation and supervision of management and the decision making process.

Yet, the role of financial institutions has attracted little academic attention so far, and limited studies have been undertaken to explore the role of financial institutions in corporate governance in China.

Tenev et al. (2002) argue that financial institutions in China have a small market presence and cannot play a stabilising role. Corporate control mechanisms and shareholder activism can do little to alleviate agency problems under the existing ownership structure. The high degree of ownership concentration and more than two-thirds of non-tradable shares imply a low contestability of control. In addition, tradable shares are held largely by individuals, who have few incentives and resources to perform monitoring functions.

Gen (2002) denies the role of financial institutions in corporate governance in China. In his point of view, financial institutions have to move their funds freely to evade the risk due to the volatility of Chinese securities market. Since they are short-term traders, how can they play a role in corporate governance in their portfolio companies?

Similarly, Zhang (2002) claims that financial institutions play a limited role in corporate governance of listed companies, compared with their counterparts in developed economies. $\mathrm{He}$ attributes this limited role to two main causes, including small quantity and market capitalisation of Chinese financial institutions, and immature of legal system. These restrictions make financial institutions become "traders" rather than "investors." analysing two cases in which financial institutions involved in corporate issues, ${ }^{45}$ he

\footnotetext{
${ }^{44}$ Brancato (1997) views shareholders as being represented along a continuum "investors" on one hand and "trader" on the other. Investors are interested in the corporation's ability to generate a stream of profits from which they can reap sustained returns. Traders focus on immediate returns on investment and base their judgments on stock price movements.

${ }_{45}$ The shareholding campaigns of Founder Technology Group Co. and Shandong Shengli Co. respectively.
} 
concludes that financial institutions have woken up and their behaviour is changing.

Tam (2002) points out that managed funds have not been able to play the anticipated role in lifting firm performance, nor instilling an element of stability in Chinese often volatile stock market activities.

In general, most financial institutions are not perceived to have played a monitoring role in corporate governance, and shareholders seek a voice in firm strategy in extreme cases and after they have exhausted all other possibilities (Mar and Young, 2001). Recently, however, financial institutions are reported to have attempted to intervene in corporate issues. These cases include financial institutions in China Vanke., the ZTE Co., the China Merchants Bank, the COSCO Shipping Co., Beiqi Foton Mortor Co. It seems that financial institutions begin to play the monitoring role in corporate governance of listed companies through the following methods as (1) publicly criticising poor management or corporate strategies; (2) putting forward the concrete measures or integrated proposal as alternatives; (3) reorganising the board of directors and management by means of soliciting for voting rights from other shareholders. (Securities Daily, $27^{\text {th }}$ October 2003). However, the effectiveness of these shareholder activities remains to be evaluated.

\subsubsection{Empirical studies on institutional ownership}

In addition, despite the large volume of literature on institutional ownership and firm performance across both market economies and transitional economies, little research on this issue has been done in a Chinese context. Limited empirical studies have examined the impact of institutional ownership held by legal person investors on firm performance, but the results are not conclusive.

\subsubsection{A positive relationship}

Using pooled firm-level data from 1993, 1994 and 1995, Xu and Wang (1997) find that the firm's profitability is positively correlated with the fraction of legal person shares, such confirming their argument that legal persons are active in monitoring managers and enhance the firm's performance.

Chen (2001) examines the cross-sectional relation between ownership structure and firm 
performance with a sample of 434 manufacturing firms listed on Chinese stock exchange. The results suggest that shares held by domestic financial institutions improve the firm performance, measured by Tobin's Q.

With a sample of 97 randomly selected firms listed on the Shanghai and Shenzhen stock exchanges from 1997 to 1999, Hovey et al. (2003) find that shareholdings by legal persons are positively related to firm performance. They then conclude that the role of financial institutions is more highly regarded in the process of corporate governance in China.

Sun and Tong (2003) evaluate the performance changes of 634 SOEs listed on Chinese two exchanges upon share issuing privatisation in the period of 1994-1998. They find a positive correlation between legal person ownership and firm performance.

\subsubsection{A negative relationship}

Yet it is also possible that legal persons create conflicts of interest within the firm and collude with managers to benefit themselves at the expense of other shareholders. With a sample of 793 firms for the period from January 1994 to June 2000, Wang et al. (2004a) report a negative relationship between legal person ownership and firm performance. In a similar vein, Chen (1998), Tian (2001), Wang (2003) find the same results.

\subsubsection{A convex relationship}

Using a sample of 5,284 firm years of Chinese partially privatised former SOEs for the period 1991-2001, Wei et al. (2005) find a significant convex relationship between institutional ownership and firm performance.

\subsubsection{No significant relationship}

Qi et al. (2000) investigate whether and how the firm performance of listed Chinese firms is affected by their shareholding structure. The sample consists of all firms listed in the Shanghai Stock Exchange from 1991 to 1996. Unfortunately, there little evidence in support of a positive correlation between firm performance and the proportion of tradable shares owned by domestic investors. Similarly, in Wei and Varela (2003)'s study, institutional ownership does not appear to improve performance. 
Although all these authors employ agency theory to analyse the relation between corporate ownership structure and firm value, they find conflicting. The time periods, sample sizes, definitions of firm performance, and statistical methods may account for the discrepancies among previous empirical studies.

\subsection{Summary}

Compared with developed economies, especially the US and UK, listed Chinese companies exist within an imperfect legal environment. The market-oriented legal system, in particular, the Corporate and Securities law framework, is still relatively rudimentary and untested in many aspects. Further, as China is still tightly controlled by the party/government, listed companies still operate under the strong influence of the government.

Listed Chinese companies have a large volume of non-tradable state and legal person shares and low percentage of tradable shares. Such ownership structure leads to insider control of the company, and puts the minority shareholders in an inferior position relative to the controlling shareholders in making corporate policies and disposing of the firms' profits and assets. Insiders hold the majority of shares, and dominate the control and management of companies. Consequently, they always pursue their goals at the expense of tradable shareholders. The ineffective governance mechanisms cannot resolve the agency conflicts between majority shareholders and minority shareholders.

Under such environment, Chinese financial institutions, with a small market presence, are not perceived to play a monitoring role in corporate governance. However, the recent attempts by some financial institutions to exert corporate control indicate that their behaviour is changing and they are exercising an important monitoring role in protecting the rights of minority shareholders.

A limited number of empirical studies on China have examined the effect of legal person ownership on firm performance, and yielded mixed results. However, According to Belev (2003), institutional investors (or legal person investors) in China are different from financial institutions in developed economies, as the former include a minority of financial organisations such as mutual funds and pension pools, and a majority of other companies such as corporatised SOEs, shareholding firms, private firms (Peng, 2004; Wang et al., 2004a). Accordingly, legal person ownership (referred to as 'overall institutional 
ownership') in extant empirical studies undertaken in the Chinese context include both financial institutional shareholdings and non financial institutional shareholdings, and remain non-tradable. As a result, the results of these empirical studies cannot clearly and correctly explain the impact of institutional ownership on firm performance. Furthermore, as financial institutions are monolithic (Wharton, 1995), the mixed findings of the extant studies may partly be a result of not distinguishing among the members of this varied group.

Therefore, it is important and necessary to assess the current role of financial institutions in corporate governance in China. The current role of these financial institutions will be explored and examined in the next three chapters. 


\section{Chapter Six}

\section{Interview Evidence from China}

\subsection{Introduction}

The previous chapters suggest that due to the conflicts of interest between principals (shareholders) and agents (managers) (Jensen and Meckling, 1976), financial institutions are emerging as an increasingly important control mechanism affecting corporate governance (Gillan and Starks, 2003).

In China, not only is there a principal-agent problem, but there are also severe principalprincipal (e.g., majority-minority shareholder) problems (Young et al., 2002), more attention needs to be paid to the role of financial institutions as monitors of corporate management to restrict in corporate governance of listed companies. Unfortunately, the role of financial institutions has attracted little academic attention so far, partly because financial institutions are not perceived to play any significant role in corporate governance (Gen, 2002). However, the literature offers no empirical evidence to support such a perception. Indeed, the recent attempts of financial institutions to intervene in corporate issues suggest that some financial institutions are exercising an important role in protecting the rights of minority shareholders. Thus, it is important to empirically reassess the current role of financial institutions in corporate governance in China. This represents a first attempt toward filling a gap in the literature. If empirical evidence confirms the perception that financial institutions indeed have very little effect on corporate governance in China, it would be interesting and important to find out why this is the case and identify ways to enhance the role. If empirical evidence suggests that financial institutions play certain important role in corporate governance, then it provides evidence that the regulatory efforts have achieved some measure of success and such effort should probably be further promoted.

To explore the role of financial institutions in corporate governance of listed Chinese companies, investigation will be undertaken in three chapters based on three different methods. Methodological triangulation is employed to enrich the results and provide a full understanding of the governance role. In this chapter, I interviewed both senior managers 
of financial institutions and board directors of listed companies. From their perspectives, I am able to provide balanced and/or more comprehensive evidence on the participation of financial institutions in corporate governance of listed Chinese companies. Moreover, the perceptions and expectations about the role of financial institutions elicited from board directors of listed companies help to explain the investor-company relations and the difference between the actual and potential role of financial institutions in corporate governance.

As an exploratory study, this chapter serves two purposes: (1) to provide a basis for formulating testable hypotheses on, and explain the results from quantitative analysis of, the role of financial institutions in corporate governance in the next chapter, and (2) to provide a basis for a qualitative analysis of the role of financial institutions in corporate governance in this chapter and chapter 8 .

The remainder of this chapter is organised as follows: Section 2 discusses the research questions. Section 3 presents research method and sample selection. Section 4 analyses and discusses the interview data, and Section 5 concludes.

\subsection{Research questions}

Based on agency theory and on the extant literature, the primary research question relates to the role of Chinese financial institutions in corporate governance of listed companies. In the role of large shareholders, financial institutions are expected to monitor corporate management on behalf of small shareholders and to take a long-term view of their shareholding positions, and, where necessary, incur expense in intervening to correct management. However, in the role of investors, financial institutions need to be free to move funds around in order to find best returns for the beneficiaries of those funds. In this respect, it is difficult to argue that institutions should continue to hold equity positions in problem companies and incur additional expense intervening in management, particularly when there is no guarantee that intervention will be successful. So what kind of role do Chinese financial institutions play? To gain an understanding of the actual role of financial institutions in corporate governance, it is necessary and important to reveal the processes in which they monitor and influence listed companies, and the barriers that affect the processes and effectiveness of financial institutions' role in corporate governance. 
In particular, I address the following three questions:

First, what are the characteristics of firms that attract institutional investment? It can be argued that financial institutions' participation in corporate governance of listed companies starts when they perform quality research beforehand in order to identify efficient firms for investing funds, thus directing scarce capital to its most efficient use and consequently enhancing corporate efficiency. So what are the characteristics of the firms that attract Chinese financial institutions? Do they consider performance, governance issues, or both of them?

Second, what are the expected and practical roles of financial institutions in corporate governance? Theoretically, financial institutions are delegated as monitors for their beneficial owners, and are expected to closely monitor their holdings and take action to protect investment against erosion in value. However, Verstegen and Marguerite (2002) argue that a mix of financial, legal, and social influence has shaped financial institution activism and affects different financial institutions to different degrees. Moreover, the institutional structures in transitional economies differ significantly from those familiar in the West (Hoskisson et al., 2000; Peng, 2000, 2003). As a result, one can expect the difference between expected and practical role of financial institutions in corporate governance. China is a developing country with characteristics of a transitional economy as well as an emerging market economy. Accordingly, Chinese financial institutions must play a different role in corporate governance in practice from that in theory.

To explore their practical role in corporate governance, it is necessary to reveal the process of their influence on listed companies. Do they just obey to the 'Wall Street Rule' when they are not satisfied with the portfolio companies? Or do they voice their dissatisfaction and intervene in the corporate issues for the rights of minority shareholders? Their behaviour in different investment stages reflects the actual role in corporate governance, as well as the nature of the relationship with their portfolio companies.

Finally, what are the factors that affect the role of Chinese financial institutions in corporate governance? Since institutional environment affects different financial institutions to different degrees, one cannot take it for granted that if financial institutions have the incentive to intervene in firms, they will be able to successfully do so. It is quite 
possible that various structural and regulatory barriers can impede this influence. These barriers can prevent institutions from fully exercising their power or motivate them to exercise it in different directions. Exploring these factors can further demonstrate that shareholder activism is the result of a mix of financial, legal, and social influence. It can also help to perfect institutional environment for financial institutions to play a greater role in corporate governance in the future.

\subsection{Research method and sample selection}

The purpose of the interviews is to allow us to enter into another person's perspective (Patton, 2002). This method is appropriate to fulfil the above mentioned purposes, as faceto-face interviews allow to investigate practical issues of institutional monitoring on management and its effect on corporate governance, to a degree unattainable, through research restricted to traditional statistical analysis and surveys of the existing literature.

I rely on social contacts to obtain interviewees in financial institutions and listed companies. I interviewed twenty senior managers from financial institutions and ten board directors over the period from June to October 2003. The interviewees from financial institutions fell into two major groups, ten from fund management companies and ten from securities companies. Twenty senior managers from financial institutions are listed in Panel A of Table 6.1, while ten board directors from listed companies are listed in Panel B of Table 6.1. These listed companies have securities companies and/or investment funds as their top ten shareholders.

Listed companies whose representatives participated in the interviews were selected by the following selection criteria: 1) A firm should not be a financial company (e.g., banks, insurance companies, and investment trusts) as financial firms account and report under different rules from other listed companies; 2) A firm should have been listed at least one full year as at the end of 2003 in order to ensure that performance and capital structure are not significantly affected by new listing that may confound the results; and 3) A firm should have securities companies and/or investment funds as their top ten shareholders.

To preserve anonymity, the names of interviewees and their companies are not disclosed. Instead, they are designated as IM1 (i.e., Investment Manager), FM1 (Fund Manager). 


\section{Table 6.1 Information about interviewees}

This table describes the information about interviewees. For Panel A, IM: Investment managers from securities companies; FM: Fund managers from fund management companies. RMB stands for Renminbi, i.e. people’s currency. In the end of 2003 , the exchange rate was about $£ 1=R M B ¥ 15.8$. Date source: the official website of the China Securities Regulatory Commission http://www.csrc.gov.cn. For Panel B, *: The companies, whose head offices in other provinces outside Beijing, established their branches in the capital of China, so all interviews were undertaken in Beijing or Shanghai. No. of institutions is the number of financial institutions as top ten shareholders of each listed company. BD: Board director; S: Securities companies; F: Fund management companies. Source: Author (2005).

\section{Panel A Information about interviewees from financial institutions}

\begin{tabular}{|l|l|l|l|l|l|}
\hline Code & Location & Registered Cap. (RMB) & Code & Location & Registered Cap. (RMB) \\
\hline IM1 & Beijing & 2.721 billion & FM1 & Shanghai & 0.132 billion \\
\hline IM2 & Guangdong & 3.450 billion & FM2 & Shanghai & 0.121 billion \\
\hline IM3 & Beijing & 1.282 billion & FM3 & Beijing & 0.152 billion \\
\hline IM4 & Beijing & 1.005 billion & FM4 & Shanghai & 0.117 billion \\
\hline IM5 & Shanghai & 3.727 billion & FM5 & Beijing & 0.138 billion \\
\hline IM6 & Guangdong & 2.015 billion & FM6 & Beijing & 0.124 billion \\
\hline IM7 & Beijing & 1.048 billion & FM7 & Shanghai & 0.113 billion \\
\hline IM8 & Beijing & 2.482 billion & FM8 & Beijing & 0.125 billion \\
\hline IM9 & Beijing & 1.510 billion & FM9 & Beijing & 0.138 billion \\
\hline IM10 & Beijing & 4.501 billion & FM10 & Beijing & 0.150 billion \\
\hline
\end{tabular}

\section{Panel B Information about interviewees from listed companies}

\begin{tabular}{|c|c|c|c|c|c|}
\hline Code & Location & Industry & Exchange & $\begin{array}{l}\text { No. of } \\
\text { institutions }\end{array}$ & Interviewee \\
\hline $\mathrm{BD} 1$ & Beijing & $\begin{array}{l}\text { Other } \\
\text { Manufacturing }\end{array}$ & Shenzhen (A) & $5 \mathrm{~F}$ & Board director and $\mathrm{CFO}$ \\
\hline $\mathrm{BD} 2$ & Beijing & Transport & Shanghai (A) & $6 \mathrm{~F}$ & Secretary to BoD and CFO \\
\hline BD3 & Beijing & Social Services & Shanghai (A) & $1 \mathrm{~F}$ & Secretary to BoD \\
\hline BD4* & Sichuan & Beverage & Shanghai (A) & $1 \mathrm{~S}$ & Board director \\
\hline BD5* & Guangdong & $\begin{array}{l}\text { Electrical } \\
\text { Equipment }\end{array}$ & Shenzhen (A) & $1 \mathrm{~F}$ & Secretary to BoD \\
\hline BD6* & Liaoning & Medicine & Shenzhen (A) & $7 \mathrm{~F}$ & Board director \\
\hline BD7 & Shanghai & Gas, water supply & Shanghai (A) & $1 \mathrm{~F}$ & Board director \\
\hline BD8* & Hebei & Mining & Shenzhen (A) & $4 \mathrm{~F}$ and $1 \mathrm{~S}$ & Secretary to BoD \\
\hline BD9 & Beijing & Medicine & Shanghai (A) & $2 \mathrm{~S}$ & Independent board director \\
\hline $\mathrm{BD} 10^{*}$ & Xinjiang & Metal & Shanghai (A) & $1 \mathrm{~S}$ & Chairman of BoD \\
\hline
\end{tabular}

All senior managers were well qualified academically and professionally, each holding a master or doctoral degree in the areas of accounting, finance, statistics, or economics. Four of them even had learning or working experience abroad. Among the twenty senior managers, fifteen had more than five years' work experience in the financial industry, and the others had five years' work experience. Among the ten board directors, nine were the 
executive directors and one independent director who was a professor from a prestigious university. The information about twenty participants from financial institutions is in Table 6.2 .

\section{Table 6.2 Information about participants from financial institutions}

This table describes information about participants from financial institutions. IM: Investment managers from securities companies; FM: Fund managers from fund management companies. Source: Author (2005).

\begin{tabular}{|l|l|l|l|l|}
\hline Code & Participant & Qualification & $\begin{array}{l}\text { Specialised } \\
\text { area }\end{array}$ & Working experience \\
\hline IM1 & investment manager & doctor & finance & 6 years \\
\hline IM2 & investment manager & master & finance & 6 years \\
\hline IM3 & investment manager & master & statistics & 5 years \\
\hline IM4 & investment manager & doctor & accounting & 9 years \\
\hline IM5 & investment manager & master & accounting & 6 years \\
\hline IM6 & investment manager & master & economics & 10 years \\
\hline IM7 & investment manager & master & economics & 5 years \\
\hline IM8 & investment manager & master & statistics & 8 years \\
\hline IM9 & investment manager & doctor & economics & 9 years \\
\hline IM10 & investment manager & master & finance & 5 years \\
\hline FM1 & fund manager & master & finance & 7 years \\
\hline FM2 & fund manager & master & economics & 8 years \\
\hline FM3 & fund manager & doctor & finance & 11 years \\
\hline FM4 & fund manager & doctor & economics & 5 years \\
\hline FM5 & fund manager & doctor & statistics & 7 years \\
\hline FM6 & fund manager & master & accounting & 10 years \\
\hline FM7 & fund manager & doctor & finance & 5 years \\
\hline FM8 & fund manager & master & statistics & 9 years \\
\hline FM9 & fund manager & doctor & finance & 9 years \\
\hline FM10 & fund manager & master & finance & 8 years \\
\hline
\end{tabular}

A seven-stage approach (Easterby-Smith et al., 1991) was adopted to sift through and process the large volumes of interview data. These stages included case familiarisation, reflection on contents, conceptualisation, cataloguing of concepts, recoding, linking, and re-evaluation. During these stages the interview responses of the various subjects were compared in order to identify common themes and problems.

In essence, the approach is one of sifting through the data in order to compare the interview responses of the various subjects and thereby to identify common themes and relationships, indicating inter-subjective understanding of research issues. Understandings were compared to the researcher's own priors and extant literature. The approach was iterative in that data and analysis was revisited on several occasions over an extended period of time. 
The iteration is an important element of the method, showing similarities to Kohak's phenomenological methods: “...a matter of looking again, looking again, each time with greater precision, till we reach a clear evident grasp" (Kohak, 1978, p23).

I contacted each interviewee in advance to secure participation and to provide them with the opportunities to consider the interview questions beforehand (see the Appendix 1). Most interviews took place in the interviewees' offices, with two in a tea house and coffee room respectively. The time for the interviews ranged from 60 to 90 minutes.

A pilot study was carried out to test the interview questions and to gain a feel about the interview process. Two pilot interviews assessed reactions to the initial draft of questions, the amount of time that the interviews would take, and any need to amend questions before commencing the main study interviews. The assessment process included comparing the actual pilot interview with initial expectations, reviewing the research design and objectives, and seeking feedback from the pilot interviewees directly. One fund manager from a fund management company and one board director from a listed company were chosen for the pilot. ${ }^{46}$ One result of the pilot study was that minor changes to the wording of questions in Chinese were made to clarify the definition of financial institutions. The use of a tape recorder was ruled out because the pilot interviewees suggested that the interviewees might object to being recorded, and using it would alter their responses consciously or unconsciously if such a concern existed. Extensive notes were taken during the interviews and subsequently typed onto a computer file after each interview.

\subsection{Analysis and discussion of interview data}

\subsubsection{The characteristics of firms that attract institutional investment}

Before investment, financial institutions carefully performed quality research on listed companies to identify investment opportunities. Jing (2004) argues that different fund resources, corporate scale and business structure between securities companies and investment funds lead to the difference in their investment preferences. In addition to some macroeconomic factors, most investment funds had used a combination of governance issues and performance measure as their selecting criteria, while most securities companies had targeted firms solely on performance.

${ }^{46}$ The two interviewees are just for the pilot interview and not included in Table 6.1. 
All interviewees from financial institutions found that the face-to-face meeting with representatives of portfolio companies was the most effective way to get information from the companies, and they were very serious and cautious with each communication. They explained why the company was chosen and what action the institution would expect from the selected company by means of sending a formal letter, giving a formal phone call, or going out with company management. Generally, they met the CFO, the secretary to the board of directors (equivalent to company secretary in the UK or US), or managers from related departments. Information collection was focused in the areas of corporate financial performance, corporate strategy, and corporate growth opportunities.

Eighteen of the twenty interviewees also employed on-spot investigation to collect information that was probably not included in the documents and reports. Investment manager "IM8" found himself cheated by the corporate management when he inspected the production line of the company and found that the line was already outdated. As a result, he gave no further consideration of that company.

After collecting the information through the these ways, the senior managers from the financial institutions had the economic capacity to hire internal and external financial analysts who can gather and digest information enabling the institutions to take thoroughly considered decisions, such as to put the funds in its most efficient use and enhance corporate efficiency. Further analysis in this section is based on the questions 1 and 2 of Panel A in the Appendix 1.

\subsubsection{Good performance}

All interviewees selected firms with good performance as their portfolio companies. In more detail, they considered the need to maintain an upward trend in the company's earnings per share, a healthy cash flow, and a reasonable level of gearing as key factors in their decision to invest. The results are not unexpected as profitability, cash flows and gearing are key indicators of a company's financial standing. The explanation of fund manager "FM4" was typical:

"Although Chinese stock market is one of the fastest growing emerging markets in the world, it is still a young market with a short history, inexperienced with the market regulation, weak in enforcement of law and rules, low in the quality of listed companies. 
Therefore, the market is fraught with problems. As fund managers, we know that the funds invested are essentially 'other people's money,' we have a fiduciary duty to tradable shareholders. A healthy cash flow and good profitability can ensure high investment return, so that we can get good return for our clients."

Investment manager "IM4" added another key point:

"We need to be free to move funds around so that we can get the best return for the beneficiaries of our funds. Chinese security market is very fluctuant and unpredictable. We expect that companies with good performance will have a good prospect. It is our job to invest the beneficiaries' money in the most profitable investment."

\subsubsection{Tradable shareholdings}

Di (2004) argues that liquidity (i.e., the percentage of tradable shareholdings) is one of the factors that financial institutions consider when making investment decisions. Support for this comes from ten fund managers and two investment managers.

According to their views, the more tradable shares, the more voting rights, the more monitoring from individual investors and financial institutions in the stock market, and accordingly, companies are under greater pressure to standardise their practice and improve their performance. As fund manager "FM5" said:

"More tradable shareholdings indicate less state or legal person holdings in China. Consequently, less political pressure will intervene in the practice of companies. Thus, companies can operate to maximise the profit on behalf of the company and shareholders." However, most investment managers had a different criterion to select portfolio companies in this regard. Eight of the ten investment managers did not care much about tradable shareholdings in a company. In their opinion, it was useless to consider because tradable ownership always accounts for only about one third of all shares in the current ownership structure of listed companies. With the low volume of shares, tradable shareholders are still very weak, and their rights are always expropriated by controlling shareholders. 


\subsubsection{Financial statements and annual report}

Prior research indicates that investors rely on the information sent out from the company to make investment decisions (Leland and Pyle, 1977; Poitevin, 1990; Ravid and Sarig, 1991). In practice, companies with good operating performance often disclose information to the public to promote positive impressions of their company (Chiang, 2005), and the most tangible form of investor communication can be seen is the financial statements and annual report.

Twelve interviewees, including nine fund managers and three investment managers, considered that the quality of financial statements and annual report was clearly a key criterion for them to select portfolio companies. Of the twelve interviewees, eight also considered the disclosure of the company's strategies and initiatives, and the quality of management's discussion and analysis of the year's results and financial position in the annual reports to be just as important. This indicates that firms with enhanced disclosure in their annual reports beyond the basic mandatory requirements can attract institutional ownership.

Most interviewees agreed that a fairly common problem existed in the prospectus, listing, right share and annual reports of listed companies, and they were disappointed with the poor quality of information disclosure, as listed companies failed to perform their obligations according to the laws and regulations. Investment manager "IM1" thought it was useless to consider the quality of information disclosure, as a significant number of listed companies only complied with disclosure standard in form but not in substance, and some even did not bother to comply with the form, for example, they might make up the accounting reports through manipulations such as managing accruals. Fund manager "FM1" said:

"One of the most important reasons why we had so many financial scandals recently is the current poor quality of financial statements and annual reports of listed companies. It implies that any further legislative changes should not ignore this point while seeking to prevent from recurrence of the highly publicised cases of fraud, error, and crime in the corporate governance process." 


\subsubsection{Quality of management}

Holland (1998) identifies the 'quality of management' as one of the most important ingredients in expected corporate financial performance. Management was the medium to change other factors such as strategy, innovation, the quality of financial reports and the functioning of board committees. In a similar vein, twelve interviewees, including eight funds managers and four investment managers, held the same opinion.

Chinese corporate managers do not suffer the pressure from external governance mechanisms such as market for corporate control and managerial labour market (Chiou and Lin, 2005). Most shares in China cannot be traded freely and thus corporate managers do not have to worry about poor management that may cause their enterprise's stock price to fall, or that their company will be faced with threat of being taken over as the market for corporate control is absent in China, and managerial labour market is still immature.

Instead, being fired by the board of directors seems to be a more serious threat to managers than an outside takeover (Bai et al., 2004). Moreover, studies with substantial evidence have indicated that the decision-making duty of the board of directors of a firm cannot really be separated from the managers' duty of implementing the decisions (Chen and Huang, 2001). Also, very serious is the phenomenon of the basic overlapping of board members and managers, or the overlapping of most board members and managers, thus executive board members are dominant in the boardroom. Therefore, the quality of Chinese corporate management is of great importance for investors to consider.

Meetings were seen as a key opportunity to collect data on the quality of management, their attitudes and managerial skills (Holland, 1998). This approach was used by twelve interviewees to collect data about the company and management. Investment manager "IM7" was not satisfied with the current quality of the management in some listed companies. He said:

"When companies come to the market to raise additional equity funds, the onus is on management to negotiate with the institutional shareholders. However, it practice, it was always the management of listed companies that were reluctant to exchange their ideas and ignored us. Sometimes we were forced to take collective actions against their corporate proposals." 


\subsubsection{Investor communications}

Seven fund managers valued the willingness of companies to provide additional information to investors, analysts and other commentators, their prompt release of information about transactions affecting minority shareholders and the existence of other transparency mechanisms that help ensure fair treatment to all shareholders. Fund manager "FM10," by contrast, was disappointed with the investor relations departments in most listed companies, as they always did not do their deeds to their words.

\subsubsection{The role of financial institutions in corporate governance}

After investment, financial institutions kept close touch with their portfolio companies and paid a great deal of attention to each change of stock prices to safeguard their investment, because they were bound together with their portfolio companies.

Since a mix of financial, legal, and social influence affects different institutions to different degrees (Verstegen and Marguerite, 2002), it is possible that Chinese financial institutions played a different role in corporate governance in practice from that in theory. The initial and best objectives expressed by the majority of the financial institutions were to contribute to their long-term investment performance. However, because of barriers to effective governance in the current stage, the majority of financial institutions are still passive shareholders. The perspectives of both senior managers of financial institutions and board directors of listed companies depicted below provide a deep understanding of the current role of financial institutions in corporate governance of listed Chinese companies. The rest of this subsection is based on the questions 3, 4, 5, and 6 of Panel A, questions 1, 2, 3, and 4 of Panel B in the Appendix 1.

\subsubsection{Expected role of financial institutions}

When asked what kind of role Chinese financial institutions should play in corporate governance of listed companies, eighteen senior managers from financial institutions and eight board directors from listed companies asserted that the financial institutions should play a role as corporate owners. In particular, they should monitor and check controlling shareholders and corporate management, protect the rights of minority shareholders, and 
improve firm performance and value of shareholders. This is well encapsulated by the remarks of board director "BD6" and fund manager "FM2":

"Financial institutions shall bring their potential into play. For example, since they are professional investors, they shall make suggestions and help us to make scientific decisions when we ask for advice or raise funds. Also, they shall prevent large shareholders from carving out assets of listed companies and shall check collusion between controlling shareholders and other large shareholders as well." (Board director "BD6")

"We have realised that we (financial institutions) cannot rely on traditional mechanisms to safeguard our investments. Instead, we have a responsibility to make considered use of our votes. Accordingly, we should encourage the firm to change its policy when we feel one of our portfolio companies is poorly managed. Recent attempts by some active investment funds to exert corporate control indicate that our behaviour is changing." (Fund manager "FM2")

Other interviewees did not think that financial institutions should play a role in corporate governance of listed companies. In their opinion, financial institutions are only professional investors, and have neither the skills nor the experience to improve on managers' decisions. Therefore, their attempts to influence corporate decisions tend to disrupt the firm's operations. Furthermore, their myopic focus on short-term earnings would deter the firm's long-term financial health.

\subsubsection{The actual role of financial institutions in China}

\subsection{Active shareholders}

Some investment funds are exercising their monitoring role in corporate governance. Five investment funds "FM2," "FM3," FM5," "FM8," and "FM9" were becoming active shareholders (or quasi-active monitors, more precisely). They helped listed companies to raise funds, standardise their practice, and establish good images in the secondary capital market by means of constructive communication with corporate management and the use of vote right at shareholders' meetings. In particular, they went so far as to intervening in corporate issues when (1) the financing violated the company constitutions, or (2) the direction of investment was inconsistent with the proposal, or (3) the financing trespassed 
the rights of minority shareholders. In terms of dividend policy, these investment funds always pushed companies to pay cash dividends, which were welcomed by tradable shareholders.

According to fund managers "FM2" and "FM8," the main purpose of some investment funds' participation in corporate issues is to improve the corporate governance of listed companies, as they believed that such changes would eventually improve firm performance. The following remarks by Director "BD2" echoed these views of the fund managers:

"In many cases investment funds helped us make financial forecast, pushed us to provide voluntary disclosures, and standardised our operation. Occasionally, they made suggestions and attempted to veto against some of our proposals that would affect the rights of minority shareholders in general shareholders' meetings. To a certain degree, their behaviour pushed us to improve corporate governance practices and firm performance as well."

Directors "BD4" and "BD7" also agreed that the participation of investment funds in corporate issues had improved the firm performance and corporate governance of their companies. For example, investment funds influenced their attitudes toward increasing shareholder benefits, asked them to cut costs and boost profits, and pushed them to improve the quality of disclosure of financial reports.

The active investment funds generally commenced with constructive, but frank communications with corporate management about firm performance and strategy. They discussed with the secretary to the board of directors, sometimes with the companies' chairmen, general managers or managers from functional departments. They explained why they were not satisfied and what action they desired from the portfolio companies. However, when a constructive dialogue failed, investment funds went to the public and voiced their dissatisfaction either independently or in conjunction with other institutional shareholders, because taking such steps was consistent with small shareholders' best interests.

In terms of voting, they usually supported the voting recommendation of a company's board. In the event of voting against a proposal, they always informed the company beforehand and explained the reasons for so doing. They used reasonable endeavours to 
seek responses from the company to address the underlying concern before they actually put their cross in the box.

When portfolio companies asked for funds, help or advice, or when they faced unusual circumstances, investment funds increased their pressure and exercised their influence via the board and senior management on problematic aspects of strategy, management quality, and financial reporting, in the expectation that this would contribute to improved financial performance. When the influence process failed, the investment funds resorted to complete sales of stock.

The five fund managers pointed out that the areas they would like to intervene in include influencing attitudes to increasing shareholder benefits, boosting profits, cutting costs, and improving the quality of disclosure of financial statements, where they had expertise and were of low intervention costs. They were very careful to only attempt to influence a firm on matters of the principle of the Code (CSRC, 2002), such as the corporate issues of the separation of chairman and CEO roles. In their opinion, influencing corporate strategy was the outside of their competence, and created deep conflict with portfolio companies. Exceptionally, they attempted to do so when such corporate strategies seriously harm minority shareholders.

Fund manager "FM9" noted that investment funds employed very few methods to effectively monitor corporate management. They seldom proposed directors to take a place on the board, and initiated litigation against companies, although they are the common ways of institutional intervention in the market economies, especially in the US and UK (Wahal, 1996).

However, these investment funds were just active monitors, not activists. "We talk to the management, and if things are not going the way they should be going, we can make suggestions," Fund manager "FM3" explained, "but we are not activists in the sense of trying to get involved in management to enforce those issues." He expressed his dissatisfaction to the public, when China Merchants Bank (CMB) proposed to issue 10 billion convertible bonds in September 2003 without any communication with its financial institutions beforehand, as this proposal would expropriate the rights of minority shareholders. Including "FM2," "FM3," FM5," "FM8," and "FM9," more than forty 
investment funds took an unprecedented collective action to vote against this proposal. ${ }^{47}$ "FM3" said then with excitement, "From the recent cases that challenged against corporate management, we seem to hear the bugle call for institutional activism." Fund manager "FM9" expressed his confidence:

"Though we eventually achieved a very limited amount of success, the fight just starts and will be much fiercer, for a long term perspective. I believe that we would win in the end, as we are becoming stronger in the capital market, looking for our own stage, and getting our voice heard."

According to board directors "BD2," "BD5" and "BD8," some investment funds really participated in improving the corporate governance of listed companies, but there was much room for them to greatly improve the effectiveness of participation. All fund managers and six investment managers suggested that efforts were needed to promote international exchanges, to organise training and consulting, to provide better education, and to realise global sharing of related experience and resources.

\subsection{Passive investors}

Drucher (1976, p82) states that "pension funds are not 'owners', they are investors. They do not want control... The pension funds are trustees. It is their job to invest the beneficiaries' money in the most profitable investment. They have no business trying to 'manage'. If they do not like a company or management, their duty is to sell the stock." Therefore, there is much anecdotal evidence to suggest that institutional shareholders do not adopt a monitoring role, preferring to sell their holdings in "problem" companies rather than intervening in the management of that company (Short and Keasey, 1997). It is the case with the majority of Chinese financial institutions.

All investment managers from securities companies and the rest fund managers (excluding the five active funds) admitted that they were just passive investors and did not take much interest in corporate governance of their portfolio companies. They tried to achieve the best return for their clients by buying and selling shares in a short period of time, relying on their judgement of the underlying strength of companies and their ability to exploit anomalies in share price. Generally, these financial institutions seldom attended the

\footnotetext{
${ }^{47}$ This case is discussed in Chapter Seven of this thesis.
} 
shareholders' meetings. There were almost no communications between financial institutions and corporate management of portfolio companies. They tolerated the problems in corporate governance as long as profits remained acceptable, and preferred to take the "Wall Street Rule" and sell when faced with serious problems.

Investment manager "IM8" said, "We have little interest in monitoring the management, showing up at shareholders' meetings and taking an active role in the company. What we are interested in is the better return from the share price gap." However, as what fund manager "FM2" explained, only in extreme cases, for example, their benefits were seriously damaged, did some financial institutions have to fight for their benefits.

Several factors explain the reluctance of Chinese financial institutions' involvement in corporate governance. First, a small amount of shareholdings prevents them from monitoring corporate management. Compared with state and legal person shareholders, financial institutions are minority shareholders, and the voting powers are not large enough for corporate control. Moreover, because of public good nature of active monitoring and the associated free-rider problem, it requires a significantly large size for shareholders (including institutions) to have the incentive to carry out these activities (Shleifer and Vishny, 1986; Admati et al., 1994). If some shareholders are active, others could take a free ride benefiting from the formers' efforts. Therefore, the best thing for small shareholders to do is to sell their shares if they are not satisfied with the way the company is running. "We are so weak that it was useless to put forward our proposals or express our concern." Investment manager "IM9" explained, "As far as I know, few suggestions were accepted in shareholders' meetings. Since we all know the result of our effort, why do we work in vain?"

Second, minority shareholders are poorly protected. "Although we are large tradable shareholders, we are also the minority." Investment manager "IM5" said, "Since it is the common fact that our concern is always ignored by listed companies, we are not willing to incur expense in intervening in listed companies' corporate issues." Board director "BD1" echoed, "It is the fact that we always neglected the voice from financial institutions. Honestly, however, major strategic decisions were mostly agreed upon beforehand among the key shareholders, typically the state, often outside the boardroom. We are usually the representatives of largest shareholder to exert control over shareholders' meetings." 
Third, investment manager "IM4" argued that financial institutions were undoubtedly skilled investors but lack expertise to advise corporate governance, and activism would detract from their primary role, which is managing money for the clients. He also questioned the incentives for some active investment funds to undertake activism. According to his view, the attempts to intervene in corporate issues might be motivated more by social influence than firm performance.

Fourth, there may be a Chinese cultural aversion to resorting to litigation that is regarded as confrontational and aggressive. Procter (1998) notes that financial institutions tend not to be become involved in corporate governance issues affecting their investments. There is a genuine reluctance to litigate issues. Investment manager "IM3" pointed out that minority shareholders tend to accept the convention that they are often not fellow stakeholders with equal rights and interests and not to "interfere" in the company's "internal affairs." This culture factor may influence financial institutions' role in corporate governance.

Fifth, according to investment manager "IM6," costs of monitoring and checking corporate management can lead to their passivity. In China, it is always the case that the costs are prohibitive compared to the amount a financial institution has at stake in the company, hence, financial institutions do not set out to become active or to micromanage companies.

Finally, investment managers "IM10" argued that, due to the recent recession of securities industry, securities companies had no incentive and power to participate in the corporate governance of listed companies. "We like clay idols fording a river - hardly able to save ourselves," "IM5" said, "let alone anyone else."

\subsubsection{Investor relationship}

The Myners Report (1995) on 'Developing a Winning Partnership' looked at how companies and financial institutions can work together. Meetings between companies and financial institutions are emphasised as a very important means of communication between the parties. In China, more and more listed companies established "Investor Relations Departments" to keep long-term relationship with their investors. The members in this department are all professional experts from securities or finance departments. The activities of an investor relations department consist of shareholder relations, disclosure, 
valuation, and capital formation. They held investor relationship meetings two or three times a year.

Fund manager "FM6" viewed the nature of investor relationship as a complex network. In his point of view, the relationship is characterised by an exchange model: invested equity is exchanged for a share of the company's residual cash flows. In addition, this primary exchange is supplemented by many interactions and continuing exchanges of information and influence.

All board directors thought it necessary and important to create an investor relations department. They argued that the increased presence of financial institutions have necessitated the establishment of such department to ensure effective communication between managers and investors, and present and potential investors can get an accurate portrayal of a company's performance and prospect through this department. Board director "BD8" noted that investor relations departments also give top managers an infrastructure for "educating" shareholders and analysts, attracting certain types of investors and retaining them as long-term partners.

Three board directors "BD2," "BD4" and "BD9" said that they had established investor relations departments, expecting to develop a good investor-corporate relationship. One of the three companies had already two relationship meetings in 2003, and its financial institution shareholders were satisfied with what it had done. The other board directors indicated that they would like to create such departments entrusted with managing the disclosure process.

Board director "BD5" was also the secretary to the board of directors and the director of the investor relationship department in his company. He disclosed the difficulty in carrying out the function of this department in practice. For example, whether companies could provide additional information to investors, such as information about transactions affecting minority shareholders, was up to the willingness of controlling shareholders.

All senior managers from financial institutions viewed an investor relations department important as it provides a convenient and natural opportunity for financial institutions to monitor and influence firm performance and accountability, and interaction and exchange 
increase the mutual level of trust and confidence between parties, and create conducive environment for continuing transactions.

There was a common view across the senior managers that there had been an improvement in communication with companies and that companies generally became more "friendly." Board directors "BD7" and "BD10" admitted that they had been very difficult to be communicated with, and until recently they have had cooperation with the financial institutions.

Fund manager "FM7" suggested a good example about investor relationship (IR):

Sinopec (China Petroleum and Chemical Corporation) was selected as having the best IR practice in the oil and natural gas industry in Asia, and the best overall IR practice in China for the last two years. This company spent nearly $\$ 200,000$ each year on investor relationship.

\subsubsection{Factors that influence the role of financial institutions in corporate governance}

Based on the question 7 of Panel A in the Appendix 1, I summarise the following factors that influence the participation of financial institutions in corporate governance emerged from the interview data.

First, all interviewees agreed that the problematic shareholding structure is the basic reason why most Chinese financial institutions played a limited role in corporate governance. The thought of the board director "BD3" was typical:

"Most listed companies have excessive concentration of non-tradable shares, and overly dispersed tradable shareholders are on the inferior position relative to controlling shareholders. The interests of minority shareholders and other stakeholders are always not respected and protected. The situation makes the voice of financial institutions invalid."

Investment manger "FM6" concurred, "Though we would like to intervene, it is very obvious that our influence does not work effectively, as we have very small size of shareholdings."

Second, a premature regulatory environment is also a barrier. The roles of financial institutions worldwide differ due to differences in various countries' stages of development 
and laws that govern their behaviour (Gillan and Starks, 2003). Zhang (2002) argues that because of the imperfect legal and supervisory environment, Chinese financial institutions are just traders, and prefer to short-term investment.

Meanwhile, in China different financial institutions are subject to different investment restrictions. For example, the current regulations limit investment fund to invest no more than 10 per cent of its total funds in one listed company and its holdings of that company should not exceed 10 per cent of that company's total shares. Such regulation restricts financial institutions by limiting their ownership stakes in individual firms, leading to a sub-optimal allocation of resources and a lack of institutional monitoring (Duggal and Millar, 1999).

Third, as a result of their roles as shareholder/investor and current or potential business service provider, financial institutions face goal conflicts, which possibly inhibit their willingness to apply pressure to company management in the event of corporate governance deficiencies. For example, in addition to holding equity in firms, some securities companies also provided financial services to their portfolio companies. Accordingly, for these investors, exchange with the firm includes the safeguarding of their investment, and the maintenance of a business relationship. The dual roles of these activities may pose a conflict of interest for these investors, which might change the proclivity towards intervention. Furthermore, in fear of retaliation, these institutions might be compelled to vote with the management even if contrary to their fiduciary interests.

Fourth, inadequate transparency and disclosure also is a barrier to taking part in corporate governance. It is widely believed that false accounting and financial misreporting are pervasive among Chinese companies. Hence, the lack of true, accurate and complete information required to analyse companies become a barrier to effective governance.

Investment manager "IM2" and fund manager "FM7" attributed the poor disclosure to the lack of effective legal punishment for reporting companies, of competition in the capital market, and of proper internal control system for disclosure within the companies.

Finally, agency problems within financial institutions prevent them from being active shareholders. Romano (1993) and Gorton and Kahl (1999) argue that financial institutions 
might be imperfect monitors due to their own internal agency problems. In the contractual relationship, the investors are the principals, and the financial institutions are their agents, who are hired based on their specific professional knowledge or expertise, and are trusted to use this expertise on behalf of the principal. Individual investors have no power to monitor the actions of institutions, and do not possess the technical knowledge to evaluate the effort invested or the outcome accomplished by financial institutions.

In this regard, institutions have a fiduciary responsibility to their principals and must use professional, objective judgment as to what is best for principals, act on their behalf, and avoid conflicts between their own interests and those of principals (Monks, 1997). However, institutional owners are agents themselves with their own goals, separate from goals of their beneficial owners. Due to information asymmetry, such agency problems as collusion and share-price manipulation arise when institutional owners find it mutually advantageous to co-operate with corporate management on certain issues. Their current or potential business relationships with the firm make them less willing actively to curb management discretion.

In addition, most Chinese financial institutions are born out of state-owned companies (Zhu et al., 2002). Accordingly, state ownership is highly concentrated in these companies as well, and large shareholders always controls management and destroy the benefit of minority shareholders. At same time, as these companies have not established sound corporate governance system, there is insufficient check and balance among the board of directors, shareholders, supervisory board and the management. Currently many financial institutions suffer the same problems as the listed companies, insufficient internal control, and entanglement of the interests of the controlling shareholders and those of the shareholders and investors (Cha, 2001).

\subsection{Conclusion}

Nowadays, there is clear evidence of corporate malpractice in China, such as illegal insider trading, market manipulation and corporate fraud (Xiao et al., 2004a). Under such context, there is practically no way for minority shareholders to protect themselves from being exploited by management or controlling shareholders. This has created an environment in 
which financial institutions could perform an important monitoring role in corporate governance.

The interview data indicate that five investment funds seemed to be active monitors and exercised their influence on corporate management, while other investment funds and all securities companies appeared to be passive shareholders and did not play any role in the corporate governance of listed companies.

Before investment, financial institutions performed quality research in order to identify efficient firms for investing funds, thus directing scarce capital to its most efficient use as and consequently enhancing corporate efficiency. Good performance, tradable shareholdings, financial statements and annual report, quality of management, and investor communications are the characteristics of companies that attract institutional investment.

The evidence from some active investment funds shows that they began to play a role in improving firm performance and standardising corporate practice of portfolio companies. Some board directors confirmed the positive effect of financial institutions' participation in corporate issues.

Because of small shareholdings, active investment funds employed very limited methods in intervening in corporate issues. The main methods included communications with corporate management, voting in general shareholders' meetings, and making public comments. They seldom proposed directors to take a place on the board, and hardly removed incumbent management and directors. In contrast, as discussed in Chapter 4, financial institutions in the US and UK employ various means, such as active use of votes at general meetings (Short and Keasey, 1997), initiating litigation against companies, to intervene corporate issues (Wahal, 1996).

The interview data also suggest that a number of factors account for this limited role played by financial institutions. The basic cause is the high ownership concentration with the segmented share structure, which leads to the insider control of listed companies in practice, and the prevalence of insider control makes Chinese financial institutions take a limited role in corporate governance (Zhou, 2004). Other factors, including a premature regulatory environment, goal conflicts, inadequate transparency and disclosure of financial information, and agency problems within financial institutions themselves also constrain 
financial institutions' ability to exert their influence on corporations. These other factors also influence the shareholder activism to a different degree in developed economies (e.g., Roe, 1990; Garten, 1992; David and Kochhar, 1996). 


\section{Chapter Seven}

\section{Institutional Shareholders and Corporate Governance: Empirical Evidence}

\subsection{Introduction}

The interview chapter explores the role of investment funds and securities companies in corporate governance. The interviews suggest that financial institutions play a limited role in corporate governance but there seems to be evidence of an improvement in corporate governance practices and firm performance.

It is argued that the objectives of financial institutions as both shareholders and investors should be to improve firm performance and that this is achieved through helping improve the standards of corporate governance (the Financial Economists Roundtable, 1998; Romano, 2001). Since financial institutions have the incentive and ability to monitor corporate management, this governance role is ultimately manifested in improved firm performance. Following much of the empirical literature that utilises ownership stakes of institutional shareholders as a proxy for their willingness and ability to undertake monitoring activities (Short and Keasey, 1997), this chapter attempts to empirically examine the relationship between firm performance and institutional shareholdings of investment funds and securities companies.

Institutional (or legal person) investors ${ }^{48}$ in China include a minority of financial organisations such as mutual funds and pension pools and a majority of other companies such as corporatised SOEs, shareholding firms, private firms (Peng, 2004; Wang et al., 2004a). Accordingly, legal person ownership (referred to as "overall institutional ownership") in extant empirical studies undertaken in the Chinese context includes both financial institutional shareholdings and non financial institutional shareholdings. This chapter focuses on securities companies and investment funds for two reasons. One, as mentioned earlier, because of legal restrictions, banks do not play any significant role in

\footnotetext{
${ }^{48}$ Shares owned by legal person investors are legal person shares.
} 
corporate governance of listed companies as they are not allowed to directly and actively hold company shares. ${ }^{49}$ Second, insurance companies also are not allowed to invest in the stock market (subject to strict quota control) until very recently, and therefore, they are unlikely to play any significant role in corporate governance in China. Therefore, different from legal person ownership, "institutional ownership" used in this chapter is the shareholdings held only by investment funds and securities companies.

This chapter provides the empirical test and results of the impact of institutional ownership held by securities companies and investment funds on firm performance. Using a large sample of 1,176 companies listed in the Chinese two stock exchanges in the period 20012003, I find that institutional shareholdings of investment funds have a positive impact on performance, while securities companies' shareholdings are not significantly related to firm performance. In addition, the findings suggest that accounting return affects the shareholdings of securities companies and investment funds. These results show that financial institutions (specifically investment funds) seem to have started to play a role in corporate governance in China, supporting the recent regulatory effort to promote financial institutions as a corporate governance mechanism. The results also highlight that it important to distinguish different types of financial institutions when examining their effects on firm performance in China.

The remainder of this chapter is organised as follows. I formulate testable hypotheses in Section 2. Section 3 describes the research design (including data sources, sample selection, variable measurement, and model specification). The empirical results are discussed in Section 4. Section 5 is devoted to robustness checks, and Section 6 concludes.

\subsection{Hypotheses development}

Chinese financial institutions are at a nascent stage of development. Because of the short history of Chinese stock market, financial institutions are relatively few in numbers and small in scale. They do not hold shares over a long period of time and sell shares when they are not satisfied with portfolio companies (Zhang, 2002). Furthermore, currently many financial institutions suffer from the same problems as the listed companies, for example,

\footnotetext{
${ }^{49}$ However, banks may occasionally and passively become shareholders of listed companies when such shareholdings are used collaterals of bank loan and the borrowing firm cannot meet its liabilities.
} 
insufficient internal control and entanglement of the interests of the controlling shareholders and those of the shareholders and investors (Cha, 2001).

However, Chinese financial institutions are profit-oriented and have incentives to pursue profits (Chen, 2001), and have played a role in corporate governance (Xu and Wang, 1999). The interviews reported in Chapter 6 suggest that financial institutions do pre-investment research to select portfolio companies, thus directing their funds to the most efficient use, and that they help portfolio companies make financial forecast, standardise practices, improve firm performance, and create good images on the secondary capital market. As mentioned earlier, investment funds and securities companies have tried to intervene into corporate strategies in several cases.

Given the aforementioned two-sided arguments, the effect of institutional shareholdings on firm performance remains an empirical issue. Therefore, to direct the empirical investigation, I formulate and test the following explorative hypothesis.

H1: firm performance is related to institutional ownership held by investment funds and securities companies, other thing being equal.

This will be used as a preliminary check on whether aggregate institutional ownership of securities companies and investment funds affects firm performance. Then, the impact of institutional ownership held by securities companies or investment funds on firm performance is examined separately.

Given that securities companies and investment funds possess different characteristics in terms of conflicts of interest, the quality of corporate governance and revenue sources, they may have a different impact on firm performance. The following section discusses in detail the potential effect of securities company shareholdings and investment fund shareholdings on the performance of Chinese companies.

Conflicts of interest. Securities companies normally have a close business relationship with their portfolio companies in the capacity of being the underwriter of share issues and/or a financial consultant. According to Pound (1988), this relationship makes them reluctant to appear openly antagonistic to management due to concern over the jeopardisation of business relationship with the firm. By contrast, monitoring and control 
activities of investment funds are unlikely to be biased by opportunities to earn other income from companies in question, as they are relatively free from conflicts of interest.

The quality of corporate governance. Some Chinese securities companies have been accused of misbehaving for years. These misbehaviours range from embezzling the deposits of clients to market manipulation (China Daily, $4^{\text {th }}$ February 2004). This is particularly the case in the period 2000-2004 when the stock market suffered a dramatic drop. As a result, many securities companies have turned into red and some of them have even become insolvent and been dissolved. Some senior executives of securities companies found guilty were sentenced. The interviews reported in Chapter 6 provides the evidence that weak corporate governance within financial institutions becomes a barrier preventing them from fully exercising their power to intervene in corporate issues of listed companies. Given that most securities companies are unlisted limited companies and so there is no effective market discipline available, it is doubtful that securities companies with generally poor corporate governance can actively participating in corporate issues of listed companies. In addition, sometimes securities companies appear in the list of top ten shareholders of listed companies not because they volunteer to do so but because they cannot sell off the underwritten shares. Therefore, it is possible that they are less willing to expend resources to actively curb management inertia.

By contrast, the investment fund industry in China has enjoyed a rapid and healthy development in recent years and now they become a major type of institutional investors (financial institutions) in the stock market (Securities Daily, $4^{\text {th }}$ January 2005). Investment funds are subject to strict monitoring from both regulators and investors. For example, they are required by law to disclose their portfolio compositions and changes in their investment on a quarterly basis. They are also required to stick to their pre-determined investment style and goals. More importantly, fund managers are under constant pressure to make good investment because investors of open-end investment funds can choose to withdraw at any time and thereby create a market discipline mechanism for fund managers. Therefore, I argue that investment funds should have more incentives to participate in their portfolio companies' corporate governance process. The interviews provide evidence that some investment funds have played a positive role in listed companies.

Revenue sources. Securities firms in China derive most of their revenues from brokerage and investment banking while dividend income and capital gains from buying shares only 
account for only a small proportion of total income (Jing, 2004). By contrast, investment funds mainly earn income from management fees that largely depend on fund size and investment performance. Therefore, compared with securities companies, investment funds are expected to have enhanced incentives to closely monitor the firms in which they invest and take action to protect investments against erosion in value.

In summary, I argue that the differences between securities companies and investment funds would lead to differing effects on the performance of their portfolio companies. Specifically, considering their poor corporate governance, conflicts of interest, and poor business performance, I predict that ownership held by securities companies should have no significantly positive impact on firm performance. By contrast, as investment funds appear to have more incentives to actively participate in the corporate issues, they are likely to have a positive impact on firm performance. Indeed, this is supported by the aforementioned recent anecdotal evidence on investment funds' attempt to veto corporate investment decisions. The two hypotheses are as follows:

H2: the percentage of ownership held by securities companies is likely to have no significantly positive effect on firm performance, other things being equal.

H3: the percentage of ownership held by investment funds is likely to have a positive effect on firm performance, other things being equal.

The hypotheses to be tested examine the effect of institutional ownership on firm performance. The empirical approach taken here is to investigate whether firm performance is affected by the shareholdings of different types of financial institutions.

\subsection{Research design}

\subsubsection{Data sources}

Major sources of information are listed as follows:

(1) Data collected from the official website of the CSRC (http://www.csrc.gov.cn), Juchao Information's website (http://www.cninfo.com.cn), and Wind Information's website (http://www.wind.com.cn) include percentages of state ownership, legal person ownership, 
and foreign ownership, shareholdings of securities companies, shareholdings of investment funds, ownership concentration (HERF_5), book value of total assets, book value of longterm debt, book value of short-term debt, book value of net fixed assets, annual sales, net profit before extraordinary items, and classification of industry.

(2) The market value of equity and managerial ownership come from the Sinofin Database compiled by Peking University, China.

(3) Data unavailable from these sources are manually collected from companies' annual reports.

\subsubsection{Sample selection}

The sample initially comprises all companies listed in the Shanghai and Shenzhen stock exchanges from 2001 to 2003 . I then impose the following selection criteria:

(1) A firm should not be a financial company (e.g., banks, insurance companies, and investment trusts) as financial firms account and report under different rules from other listed companies;

(2) A firm should have been listed at least one full year as at the end of 2003 in order to ensure that performance and capital structure are not significantly affected by new listing that may confound the results;

(3) A firm/year should not have missing data.

The above criteria yield a usable sample of 1,176 firms (3,273 observations). The period 2001-2003 is chosen for three reasons. (1) During this period there was a remarkable growth in equity portfolios of financial institutions and more and more financial institutions became top ten shareholders of listed companies. (2) This period saw a reported increase in financial institutions seeking their voices in corporate issues. And (3) 2001 was the year when China issued the first open-end securities investment fund, therefore this period of 2001-2003 represents the earliest and latest years for which complete data of open-end securities investment funds was available for my study. 


\subsubsection{Variables}

I follow the prior literature to operationalise the variables used in this chapter. This allows me to highlight the similarities, as well as the difference (if any) in the effect of institutional ownership on firm performance between China and other countries.

\subsubsection{Dependent variable: firm performance}

Both Tobin's Q and accounting profitability ratio Return on Asset (ROA) are used to investigate the relationship between firm performance and institutional ownership.

Tobin's Q has been widely embraced as a measure of firm performance in the accounting and finance literature. In theory, the $Q$ ratio identifies the juxtaposition of the managerial efficiency of capital and the financial cost of capital (Tobin, 1969, 1978). Typically, in the finance and accounting literature, average $Q$ is taken as a proxy for marginal $Q$, since it is shown by Hayashi (1982) to be a sound substitute. In essence, the ratio gauges the marginal efficiency of capital compared to the financial cost of capital. This approach captures whether the value of a firm as an operational business is greater than the cost of the assets required to generate its cash flow, at that point in time. Thus, Tobin's $Q$ is positively related to investors' perception of managerial quality.

Several studies use Tobin's Q as a proxy for firm performance. For example, Morck et al. (1988) use $Q$ to measure the relation between firm performance and corporate ownership structure. McConnell and Servaes (1990) use Q to measure the relation between firm performance and institutional ownership. Chen et al. (1993) use $Q$ to measure the relation between corporate value and management ownership. Lang and Stulz (1994) use Q to measure the relation between firm value and corporate diversification. Woidtke (2002) use industry-adjusted $\mathrm{Q}$ to measure the expected valuation effects from both observable and unobservable aspects of the relationship between pension funds and their portfolio firms. Under the Chinese context, a few studies use Tobin' Q. Chen (2001) uses Q to examine the relation between ownership structure and firm performance of manufacturing listed companies. Hovey et al. (2003) use Q to measure the relationship between firm performance and share ownership of listed companies. 
Tobin's $Q$ is defined as the ratio of the market value to the replacement of the firm, which can be measured as the market value of equity and debts over the replacement cost of net fixed assets and inventory (Lindenberg and Ross, 1981; Xu and Wang, 1997). In China, there is not a well-developed corporate debt market and few of the listed Chinese companies issue publicly placed debt. As a result, it is almost impossible to calculate the market value of their debt and replacement values of the assets. In this chapter, Tobin's $Q$ is defined as the simple Q measure in Chung and Pruitt (1994), Perfect and Wiles (1994), Agrawal and Knoeber (1996), Chen (2001), Wiwattanakantang (2001), and Hovey et al. (2003). $Q$ is defined as follows:

$\mathrm{Q}=\mathrm{V} / \mathrm{ASSET}$

Where, V = EQUITY + LTD + STD; EQUITY = Market value of equity; LTD = Book value of long-term debt; STD = Book value of short-term debt; ASSET = Book value of total assets.

Perfect and Wiles (1994) report that this measure of $Q$ has a correlation of 0.93 with that estimated using the Lindenberg and Ross (1981) approach. I adopt the simple measure of Q because of this high correlation and its ease of computation, to maximise the availability of data, and to avoid the arbitrary assumptions about depreciation and inflation rates (e.g., Shin and Stulz, 1998).

As the shares held by the state and most other legal persons are not publicly tradable, to avoid overestimation, I proxy the market value of non-tradable shares as the number of total non-tradable shares multiplied by net assets per share (e.g., see Zou et al., 2003). In practice, such non-publicly tradable shares can be transferred through negotiation based on net assets per share plus a premium. The market value of tradable shares is computed as the year-end share price multiplied by the number of tradable shares.

To be cautious with $\mathrm{Q}$ as the (market-based) proxy of firm performance in a nascent stock market, I use return on assets (ROA) as an alternative measure of firm performance. I calculate ROA as net profit before extraordinary items divided by the average book value of total assets. This is necessary because managers of listed Chinese companies often manage the reported bottom-line profit figures via one-time accounting items (e.g. via investment income, sale of assets) (Chen and Yuan, 2004). 


\subsubsection{Test variables: the percentage of institutional ownership}

As listed Chinese companies are only required to disclose the holdings of top ten shareholders, I use the percentage of common shares owned by securities companies and investment funds in the top ten shareholders as the main independent variables in the regression models. ${ }^{50}$ INST is measured by the ratio of the number of shares held by securities companies and investment funds to the total number of common shares in issue. INST_S is measured by the ratio of the number of shares held by securities companies to the total number of common shares in issue. INST_F is measured by the ratio of the number of shares held by investment funds to the total number of common shares in issue at the end of each accounting year.

\subsubsection{Control variables}

The following independent variables are included in the regressions as control variables. These control variables represent factors that have been well documented in the previous research studies (e.g., Morck et al., 1988; McConnell and Servaes, 1990) as being determinants of $\mathrm{Q}$.

State ownership (STATEO): State ownership is traditionally viewed as contributing to, if not causing, corporate operational inefficiency (Dewenter and Malatesta, 2001). Consistent with such a view, Gul (1999) and Xu and Wang (1999) find evidence that in China high levels of state ownership often results in lackluster financial performance. Chen (2001) presents evidence to show that state ownership, either in the form of state agents or in the form of state solely owned institutions, leads to inefficiency of capital allocation. Following these studies, the effect of state ownership is controlled for. STATEO is the ratio of the number of shares owned by the state and state-owned legal persons to the total number of common shares in issue at the end of each accounting year.

Legal person ownership (LPO): legal person ownership is controlled for because several studies find empirical studies to support the argument that legal persons are active in monitoring managers and enhancing firm performance (Xu and Wang, 1999; Qi et al.,

\footnotetext{
${ }^{50}$ This treatment may understate the ownership of financial institutions. However, as shareholdings outside the top ten are normally quite small and so I think that this omission is unlikely to materially bias the results.
} 
2000). However, Chen (1998) and Wang et al. (2004a) report a negative relationship. LPO is the percentage of total shares at the end of each accounting year held by domestic corporations and other non-individual entities (Chen and Wang, 2004). Here I deduct the non-tradable shares held by securities companies from total legal-person shareholdings to avoid double count.

Managerial ownership (MAO): Managerial ownership helps align the interests of shareholders and managers, according to the "convergence of interest" hypothesis. As a result, as the proportion of managerial equity ownership increases, so does firm performance. However, the "managerial entrenchment" hypothesis predicts that corporate assets are more likely to be squandered by managers who become entrenched when possessing large stockholdings in the firm. As the percentage of shares held by managers, directors and supervisory board members is relatively insignificant in China, ${ }^{51}$ it is considered that their overall influence is also quite limited (Hovey, 2002). Gul and Zhao (2000) report that the percentage of shares held by board directors and supervisors is not significantly related to firm performance in China. However, $\mathrm{Li}$ et al. (2005) find evidence that managerial ownership contributes positively to firm performance. Following these studies, I control for the effect of managerial ownership. MAO is the percentage of common stock owned by managers at the end of each accounting year.

Foreign ownership (FORO): Conventional theory holds that foreign ownership tends to more closely monitor firms they invest in, and thus improves firm performance (e.g., Hovey, 2002). Chhibber and Majumdar (1999) find that foreign ownership of 51 per cent or higher has a positive influence on performance in India. In the Chinese context, Xu et al. (2005) and Wei et al. (2005) document a positive relationship, while Qi et al. (2000) report a negative relationship between foreign ownership and firm performance. Unfortunately, Sun and Tong (2003) fail to find a significant relationship. Following these studies, I control for the effect of foreign ownership. FORO is the percentage of shares (including Bshares, H-shares, and non-tradable foreign founders' shares) held by foreign investors at the end of each accounting year.

Ownership concentration (HERF_5): Shleifer and Vishny (1986) argue that large shareholders may help reduce the free-rider problem of small investors and some degree of

\footnotetext{
${ }^{51}$ The average managerial ownership is $0.11 \%$ in the period of $2000-2002$ in Table 7.2.
} 
ownership concentration enhances firm performance. Studies in market economies suggest that improving performance and creating value can be achieved by paying attention to ownership structure and concentration. Demsetz and Lehn (1985) find a linear relationship between ownership concentration and ex-post firm performance measures. Many studies conducted in China also document a linear relationship between ownership concentration and firm performance (e.g., Chen and Gong, 2000; Gul and Zhao, 2000). However, Hovey (2002) and Hovey et al. (2003) fail to find an explanatory power of ownership concentration on firm performance. To control for the effect of ownership concentration on firm performance, I include a Herfindahl index (HERF_5) calculated as the average of the sum of squares of percentage of shares held by each top five shareholder.

Leverage (LEVE): Leverage may affect firm performance in many ways. For example, the interest burden of debt, on the one hand, may increase expenses; on the other hand, it also results in tax shields and so is beneficial to firm value (e.g., Morck et al., 1988). Leverage may also magnify business operating risk and so makes a firm's earnings more volatile, other things being equal. In China's "policy lending" regime, higher leverage may imply the availability of state funding for corporate operation that may contribute to firm value. Alternatively, the existence of such "policy lending" may be associated with financially troubled firms. Therefore, in China the effect of leverage on firm value is ambiguous. Indeed, Qi et al. (2000) and Tian (2001) report a negative effect on market performance, while Sun and Tong (2003) find a positive impact on market performance, but a negative impact on accounting returns. I measure leverage as the debt-to-asset ratio, which equals the total value of debt divided by the book value of total assets.

Tangibility (TANG): Tangibility is included to control for variations in firm's input structures that may affect factors such as capital market influences and managerial decisions (Wang, 2003). Further, agency costs may be higher in companies of a lot of growth options and hence lower tangible asset intensity (Smith and Watts, 1992). Tian (2001) and Wang (2003) report a negative relationship between asset tangibility and firm performance. Tangibility is measured by the fixed asset ratio as the net fixed assets over total assets (Wiwattanakantang, 1999; Tian, 2001; Xiao et al., 2004b).

Firm size (SIZE): Firm size is expected to have a negative impact on firm performance, as the market concerns about greater agency problems for larger firms (Sun and Tong, 2003). 
In this chapter, I take SIZE as a proxy to explain bureaucratic inefficiencies as a result of the size of the firm. Firm size can be measured in different ways, using total asset, annual sales or market value of equity as a proxy of firm size. In this section, firm size is measured as the natural logarithm of a firm's annual sales, because the dependent variable $Q$ already incorporates market and asset values. The literature also shows that alternative measures of size do not materially affect the results (Chen, 2001). I expect this variable to be negatively related to firm performance.

Year dummy (YED): To control for changes in macroeconomic environment over the period 2001-2003, year dummies should be considered (Qi et al., 2000; Wang, 2003). Here two year dummies are used. YED1 takes the value of 1 for year 2001, and zero otherwise. YED2 takes the value of 1 for year 2002, and zero otherwise.

Regulatory status (REGUL): Zou et al. (2003) report that firms in regulated industries (e.g., utilities, energy, and telecommunication) in China may enjoy a price protection and so they are less vulnerable to risks caused by market competition. Such firms also potentially have the ability to pass any extra business costs onto customers. Therefore, as Sun and Tong (2003), I include a dummy variable (REGUL) that takes the value 1 for a regulated firm and the value of zero otherwise to control for the effect of a firm's regulatory status on firm performance.

\subsubsection{Regression models}

The hypotheses tested here are that firm performance is a function of the firm's institutional ownership and other control variables. However, the results are difficult to interpret when there is a problem of endogeneity. For example, it might be possible that good firm performance attract more investment form financial institutions. To mitigate this concern, as Hermalin and Weisbach (1991), I regress the contemporaneous performance measures on the lagged values of the explanatory variables. The empirical models employed are as follows:

Tobin's $\mathrm{Q}_{i t}\left(\mathrm{ROA}_{i t}\right)=\alpha_{1}+\alpha_{2} \mathrm{INST}_{i t-1}+\alpha_{3} \mathrm{C}_{i t-1}+\varepsilon_{1 i t}$

Tobin's $\mathrm{Q}_{i t}\left(\mathrm{ROA}_{i t}\right)=\beta_{1}+\beta_{2} \mathrm{INST} \mathrm{S}_{i t-1}+\beta_{3} \mathrm{INST}_{-} \mathrm{F}_{i t-1}+\beta_{4} \mathrm{C}_{i t-1}+\varepsilon_{2 i t}$ 
Where $\beta_{i}$ represents coefficient; $\varepsilon$ is an error term with a mean of zero; $C_{i t-l}$ contains STATEO, LPO, MAO, FORO, SIZE, LEVE, TANG, HERF_5, YED1, YED2, and REGUL. All the dependent and independent variables are defined above. I examine STATEO and LPO in separate regressions due to their high correlation $\left(\beta_{1}=-0.828\right)$.

Since there are certain doubts over the direction of causality in the equation above, I will also test the effect of Tobin's Q (or ROA) on institutional ownership in order to be sure of the direction of causality. The estimation with a system of simultaneous equations allows me to further address the potential endogeneity problem (Cho, 1998). This analysis attempts to obtain a more in-depth knowledge about mutual relationship between firm performance and institutional ownership. By so doing, I can check the possible endogeneity of ownership and the direction of causality, in comparison with the results of the singleequation models.

\subsection{Empirical analyses}

\subsubsection{Descriptive statistics}

The summary statistics relating to firm performance, the distribution of ownership, and other control variables are reported in Tables 7.1, 7.2 and 7.3 respectively.

Statistics relating to the performance of companies from 2001 to 2003 are presented in Table 7.1. The average Tobin's $\mathrm{Q}$ and ROA are 1.524 and 0.007 over the three years respectively. In particular, mean Tobin's $Q$ has decreased from 1.754 in 2001 to 1.328 in 2003, while the mean of ROA has decreased from 0.009 in 2001 to 0.007 in 2003. Q seems to have declined over time probably reflecting the drop in stock market, which justifies the need to control for the effect of time-related factor on firm performance.

Table 7.2 reports the distribution of ownership structure of 3,273 observations from companies listed on the Shanghai and Shenzhen stock exchanges from 2000 to 2002. It is clear that institutional ownership of securities companies and investment funds generally increased over the sample period, but still represents an insignificant fraction (each holding less than 1 per cent of total shares in issue). Mean aggregate ownership increased from 0.9 per cent in 2000 to 1.4 per cent in 2002, and the median from 0.0 per cent in 2000 to 0.5 per cent in 2002. In particular, the mean of institutional ownership held by securities 
companies increased from 0.2 per cent in 2000 to 0.7 per cent in 2002 , and the mean of ownership held by investment funds increased from 0.5 per cent in 2000 to 0.7 per cent in 2002. These figures imply that, in general, institutional shareholder concentration has increased over the period.

The table shows that the percentage of equity owned by state accounts for about one third of total shares. The mean state ownership was 35.5 per cent in 2000 , as opposed to the means of 37.3 per cent and 38.7 per cent in 2001 and 2002, respectively. In terms of legal person ownership, it appears that the percentage of legal person ownership has increased slightly over the period. In 2000 , the mean ownership was 17.1 per cent, as opposed to the means of 19.2 per cent and 19.8 per cent in 2001 and 2002, respectively.

Managerial ownership increased obviously from 2000 to 2002. The mean managerial ownership has increased from 0.1 per cent in 2000 to 0.2 per cent in 2002 . In contrast, the mean foreign ownership has decreased from 2.9 per cent in 2000 to 1.9 per cent in 2002 and the ownership concentration HERF_5 had decreased from 27.9 per cent in 2000 to 4.8 per cent in 2002. The decrease might explain the changes among state ownership, legal person ownership, and institutional ownership.

\section{Table 7.1 Firm performance variables}

This table presents summary statistics about firm performance. The sample consists of 1,176 firms $(3,273$ observations) listed on the Shanghai and Shenzhen stock exchanges over the period of 2001-2003. (1) Tobin's Q: (market value of equity + book value of long-term debt + book value of short-term debt)/book value of total assets. (2) ROA: the ratio of net profit before extraordinary items by the average book value of total assets.

\begin{tabular}{|c|c|c|c|c|c|c|c|}
\hline Variable & Mean & Median & Std. Dev. & Minimum & Maximum & Skewness & Kurtosis \\
\hline \multicolumn{8}{|c|}{ Panel A: 1022 firms listed on the SHSE and SZSE with data available in 2001} \\
\hline Tobin's Q & 1.754 & 1.578 & 0.851 & 0.528 & 14.155 & 0.676 & 0.558 \\
\hline ROA & 0.009 & 0.027 & 0.168 & -3.560 & 0.190 & -0.611 & 2.340 \\
\hline \multicolumn{8}{|c|}{ Panel B: 1102 firms listed on the SHSE and SZSE with data available in 2002} \\
\hline Tobin's Q & 1.514 & 1.329 & 0.717 & 0.846 & 11.312 & 0.632 & 0.728 \\
\hline ROA & 0.005 & 0.022 & 0.164 & -3.765 & 0.222 & -0.699 & 2.588 \\
\hline \multicolumn{8}{|c|}{ Panel C: 1149 firms listed on the SHSE and SZSE with data available in 2003} \\
\hline Tobin's Q & 1.328 & 1.203 & 0.499 & 0.831 & 7.428 & 0.561 & 0.662 \\
\hline ROA & 0.007 & 0.019 & 0.094 & -1.571 & 0.220 & -0.722 & 3.626 \\
\hline \multicolumn{8}{|c|}{$\begin{array}{l}\text { Panel D: } 3273 \text { annual observations for firms listed on the SHSE and SZSE between } 2001 \text { and } \\
2003\end{array}$} \\
\hline Tobin's Q & 1.524 & 1.335 & 0.718 & 0.528 & 14.155 & 0.653 & 0.782 \\
\hline ROA & 0.007 & 0.023 & 0.145 & -3.765 & 0.222 & -0.848 & 3.737 \\
\hline
\end{tabular}




\section{Table 7.2 Ownership variables}

This table presents summary statistics about ownership. The sample consists of 1,176 firms $(3,273$ observations) listed on the Shanghai and Shenzhen stock exchanges over the period of 2001-2003. (1) INST: the ratio of the number of shares held by securities companies and investment funds to the total number of shares in issue. (2) INST_S: the ratio of the number of shares held by securities companies to the total number of shares in issue. (3) INST F: the ratio of the number of shares held by investment funds to the total number of shares in issue. (4) STATEO: the ratio of the number of shares owned by the state and state-owned legal persons to the total number of shares in issue. (5) LPO: the percentage of total shares held by domestic corporations and other non-individual entities. I deduct the non-tradable shares held by securities companies from total legal-person shareholdings to avoid double count. (6) MAO: the percentage of stock owned by managers. (7) FORO: the percentage of shares held by foreign investors. (8) HERF_5: the average of the sum of squares of percentage of shares held by each top five shareholder.

\begin{tabular}{|c|c|c|c|c|c|c|c|}
\hline Variable & Mean & Median & Std. Dev. & Minimum & Maximum & Skewness & Kurtosis \\
\hline \multicolumn{8}{|c|}{ Panel A: 1022 firms listed on the SHSE and SZSE with data available in 2000} \\
\hline INST & 0.009 & 0.000 & 0.018 & 0.000 & 0.157 & 3.387 & 3.876 \\
\hline INST_S & 0.002 & 0.000 & 0.007 & 0.000 & 0.093 & 3.415 & 4.186 \\
\hline INST_F & 0.005 & 0.000 & 0.017 & 0.000 & 0.157 & 3.297 & 3.341 \\
\hline STATEO & 0.355 & 0.392 & 0.240 & 0.000 & 0.886 & 0.169 & -0.303 \\
\hline LPO & 0.171 & 0.064 & 0.213 & 0.000 & 0.850 & -0.042 & -1.575 \\
\hline MAO & 0.001 & 0.000 & 0.004 & 0.000 & 0.130 & 0.258 & 3.439 \\
\hline FORO & 0.029 & 0.000 & 0.091 & 0.000 & 0.499 & 0.313 & 0.867 \\
\hline HERF 5 & 0.279 & 0.251 & 0.164 & 0.001 & 0.876 & 0.774 & 0.153 \\
\hline \multicolumn{8}{|c|}{ Panel B: 1102 firms listed on the SHSE and SZSE with data available in 2001} \\
\hline INST & 0.010 & 0.001 & 0.019 & 0.000 & 0.254 & 3.364 & 3.329 \\
\hline INST_S & 0.005 & 0.000 & 0.015 & 0.000 & 0.203 & 4.058 & 3.451 \\
\hline INST_F & 0.007 & 0.000 & 0.011 & 0.000 & 0.130 & 3.224 & 2.522 \\
\hline STATEO & 0.373 & 0.418 & 0.262 & 0.000 & 0.886 & -0.218 & -1.328 \\
\hline LPO & 0.192 & 0.079 & 0.236 & 0.000 & 0.967 & 0.948 & -0.467 \\
\hline MAO & 0.001 & 0.000 & 0.010 & 0.000 & 0.287 & 0.253 & 3.891 \\
\hline FORO & 0.021 & 0.000 & 0.072 & 0.000 & 0.621 & 0.403 & 1.705 \\
\hline HERF_5 & 0.049 & 0.044 & 0.030 & 0.000 & 0.145 & 0.642 & -0.347 \\
\hline \multicolumn{8}{|c|}{ Panel C: 1149 firms listed on the SHSE and SZSE with data available in 2002} \\
\hline INST & 0.014 & 0.005 & 0.022 & 0.000 & 0.145 & 2.371 & 2.484 \\
\hline INST_S & 0.007 & 0.000 & 0.015 & 0.000 & 0.145 & 3.500 & 3.598 \\
\hline INST_F & 0.007 & 0.001 & 0.015 & 0.000 & 0.137 & 3.319 & 3.112 \\
\hline STATEO & 0.387 & 0.433 & 0.254 & 0.000 & 0.850 & -0.304 & -1.239 \\
\hline LPO & 0.198 & 0.083 & 0.226 & 0.000 & 0.800 & 0.964 & -0.413 \\
\hline MAO & 0.002 & 0.000 & 0.019 & 0.000 & 0.338 & 0.139 & 2.107 \\
\hline FORO & 0.019 & 0.000 & 0.070 & 0.000 & 0.529 & 0.405 & 1.638 \\
\hline HERF_5 & 0.048 & 0.043 & 0.030 & 0.000 & 0.144 & 0.632 & -0.326 \\
\hline \multicolumn{8}{|c|}{$\begin{array}{l}\text { Panel D: } 3273 \text { annual observations for firms listed on the SHSE and SZSE between } 2000 \text { and } \\
2002\end{array}$} \\
\hline INST & 0.011 & 0.002 & 0.020 & 0.000 & 0.254 & 3.235 & 3.133 \\
\hline INST_S & 0.005 & 0.000 & 0.013 & 0.000 & 0.203 & 3.491 & 3.395 \\
\hline INST_F & 0.006 & 0.000 & 0.014 & 0.000 & 0.157 & 3.051 & 2.417 \\
\hline STATEO & 0.315 & 0.332 & 0.270 & 0.000 & 0.886 & 0.100 & -1.486 \\
\hline LPO & 0.245 & 0.136 & 0.259 & 0.000 & 0.967 & 0.626 & -1.108 \\
\hline MAO & 0.001 & 0.000 & 0.130 & 0.000 & 0.338 & 0.200 & 4.388 \\
\hline FORO & 0.023 & 0.000 & 0.078 & 0.000 & 0.621 & 0.370 & 1.333 \\
\hline HERF 5 & 0.121 & 0.064 & 0.143 & 0.000 & 0.876 & 0.203 & 0.403 \\
\hline
\end{tabular}


Other firm characteristics such as TANG, SIZE, LEVE, and REGUL are presented in Table 7.3 .

\section{Table 7.3 Other characteristic variables}

This table presents summary statistics about other characteristics of companies. The sample consists of 1,176 firms (3,273 observations) listed on the Shanghai and Shenzhen stock exchanges over the period of 20012003. (1) TANG: the ratio of net fixed assets over total assets. (2) SIZE: the natural logarithm of firm's annual sales. (3) LEVE: the ratio of the total value of debt by the book value of total assets. (4) REGUL: regulatory status with the value 1 for a regulated firm and the value of zero otherwise.

\begin{tabular}{lrrrrrrrr}
\hline Variable & \multicolumn{1}{c}{ Mean } & \multicolumn{1}{c}{ Median } & Std. Dev. & Minimum & Maximum & Skewness & \multicolumn{2}{c}{ Kurtosis } \\
\hline 3273 annual observations for firms listed on the SHSE and SZSE between 2000 and 2002 & \\
TANG & 0.298 & 0.269 & 0.177 & 0.001 & 1.011 & 0.717 & 0.147 \\
SIZE & 20.120 & 20.114 & 1.310 & 8.006 & 26.848 & -0.704 & 5.762 \\
LEVE & 0.462 & 0.435 & 0.334 & 0.000 & 8.502 & 0.115 & 2.596 \\
REGUL & 0.110 & 0.000 & 0.316 & 0.000 & 1.000 & 2.459 & 4.050 \\
\hline
\end{tabular}

\subsubsection{Correlation analysis}

Before running the regression models, a bivariate correlation analysis of the dependent and independent variables was conducted. Panel A of Table 7.4 reports the calculated Pearson correlation coefficients between variables. Focus first on the correlation coefficients among the dependent and independent variables. INST and INST_F have significant and positive correlations with both Tobin's Q and ROA. By contrast, INST_S is not significantly associated with either Tobin's Q or ROA.

LPO exhibits significant and positive correlations with both Tobin's Q and ROA. STATEO, TANG, and SIZE have significant negative correlations with both Tobin's $Q$ and ROA. HERF_5 has a significant positive correlation only with Tobin's Q. Finally, LEVE has a significant negative correlation with Tobin's Q, but a positive correlation with ROA. These correlation coefficients provide some preliminary support for the hypotheses.

Panel A of Table 7.4 also shows that among the independent variables, a rather strong and significant negative correlation exists between STATEO and LPO $\left(\beta_{1}=-0.828\right)$. Strong and significant positive correlations also exist between INST and INST_S $\left(\beta_{2}=0.704\right)$, and INST and INST_F $\left(\beta_{3}=0.759\right)$. All the remaining correlations are relatively low. 
To further assess the potential for multicollinearity, I perform regressions of all independent variables on Tobin's $Q$. The maximum variance inflation factors (VIF) from the model (presented in Panel B of Table 7.4) is 3.614, well below the rule of thumb cutoff of 10.0 for multiple regression models (Neter et al., 1985; Kennedy, 1998). Thus I can conclude that multicollinearity is unlikely a serious problem in this study.

\subsubsection{Multivariate results}

Since Himmelberg et al. (1999) show that unobserved heterogeneity across firms can generate a spurious correlation between ownership and performance (if the unobserved, exogenous variables are correlated with ownership and performance), I estimate a firmspecific, fixed-effects model using the three-year panel dataset. Such a specification controls for omitted (unobservable) heterogeneous firm-specific effects (e.g., industry factor), and/or time-specific effects (e.g., macroeconomic cycles) (Greene, 1999). Himmelberg et al. (1999) also argue that a panel data research design is well suited for analysing the ownership-performance relation as it controls for potentially confounding unobserved effects. Additionally, Zou and Adams (2004) consider that the use of a fixedeffect model could help to mitigate data measurement errors (e.g., due to omitted variables). Once individual (or firm-specific) time invariant variables are controlled for, the possible effect of industry is also controlled for, thus using industrial dummies is not necessary under such formulation (Sun et al., 2002).

Firm-specific characteristics may give rise to cross-sectional heteroskedasticity. To address this, White's (1980) corrected standard errors is used to control for the existence of heteroskedasticity. If heteroskedasticity is found, White's correction is used to adjust the standard errors.

Table 7.5 displays the results of eight regression models used to test $\mathrm{H} 1, \mathrm{H} 2$, and $\mathrm{H} 3$. These models were derived from two alternative measures of firm performance (Panel A for Tobin's Q and Panel B for ROA) with two subsets of ownership variables STATEO and LPO. $^{52}$

\footnotetext{
${ }^{52}$ This segmentation of the ownership variables was aimed at reducing multicollinearity threats from the high correlation between STATEO and LPO $(\beta=-0.828)$.
} 


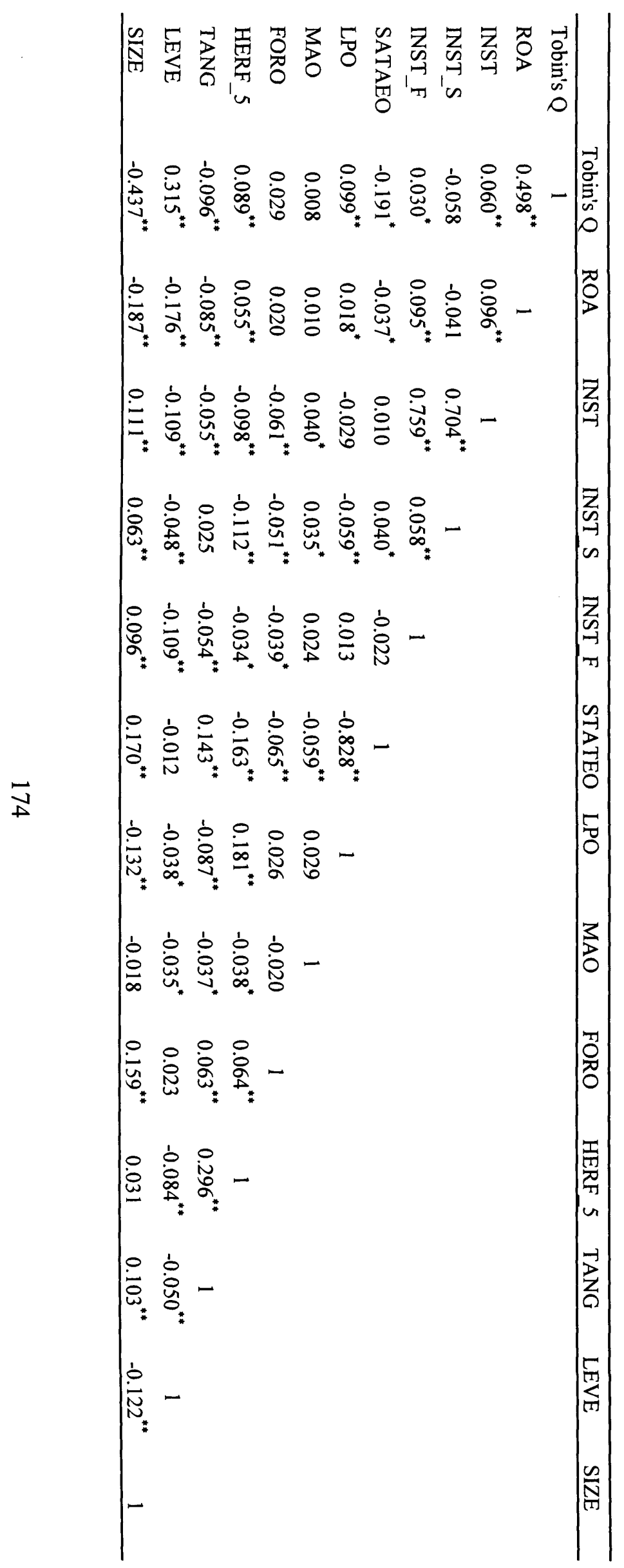

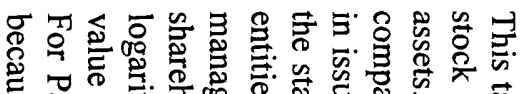

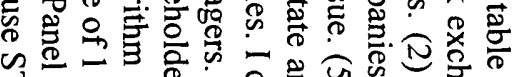

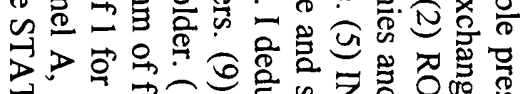

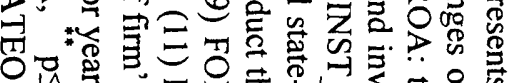

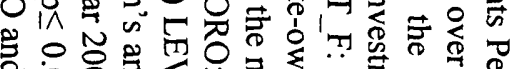

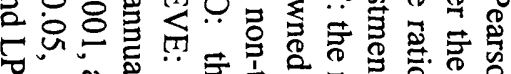

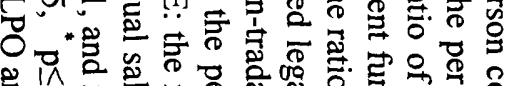

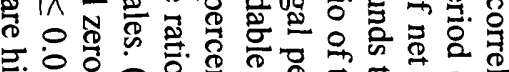

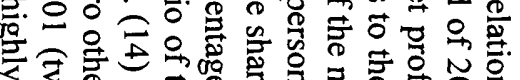

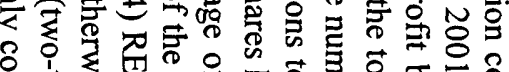

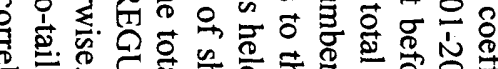

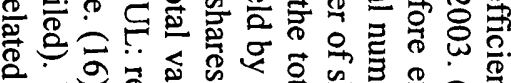

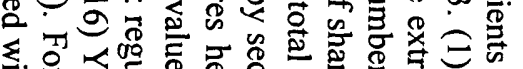

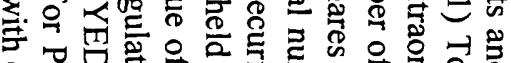

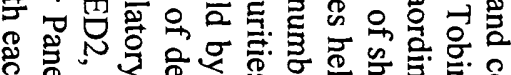

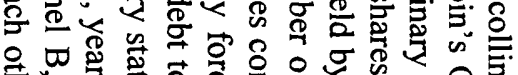

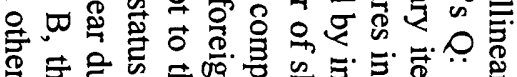

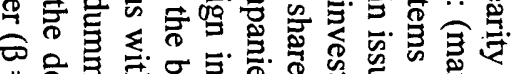

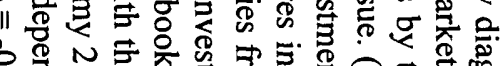

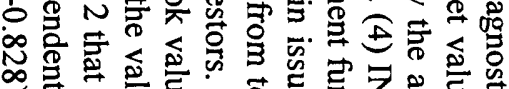

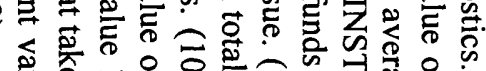

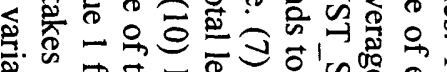

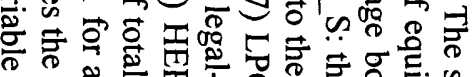

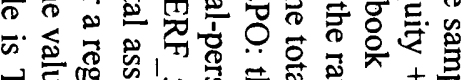

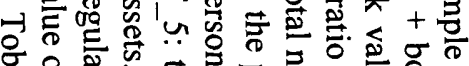

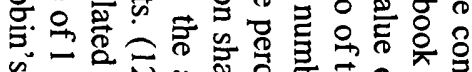

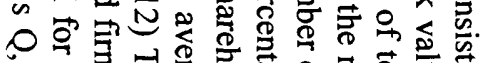

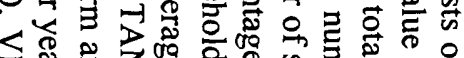
ii

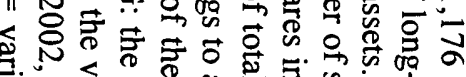

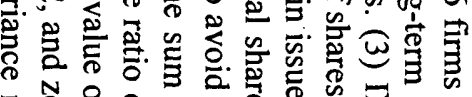

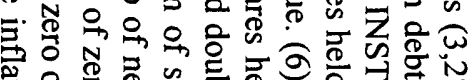

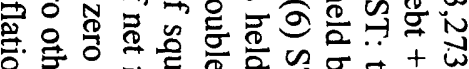

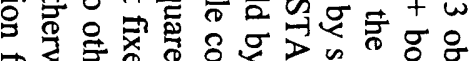

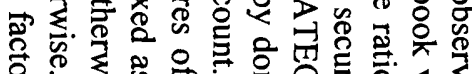

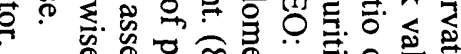

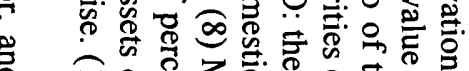

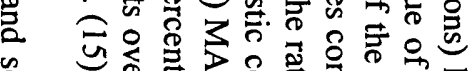

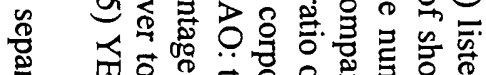
团实

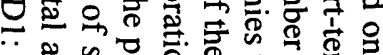

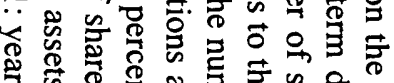
为

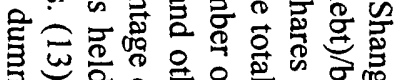

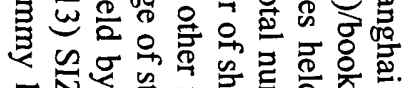

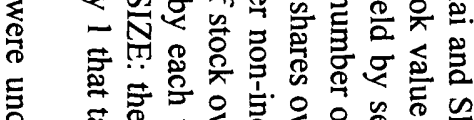

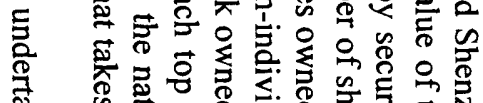

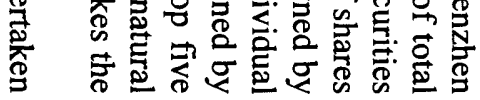


Panel B Variance inflation factors (VIFs)

\begin{tabular}{lcccc}
\hline & VIF & VIF & VIF & VIF \\
\hline INST & 1.052 & 1.051 & & \\
INST_S & & & 1.042 & 1.042 \\
INST_F & & & 1.047 & 1.047 \\
STATEO & 1.226 & & 1.226 & \\
LPO & & 1.115 & & 1.116 \\
MAO & 1.012 & 1.009 & 1.012 & 1.009 \\
FORO & 1.050 & 1.043 & 1.050 & 1.043 \\
HERF_5 & 3.227 & 3.187 & 3.238 & 3.197 \\
TANG & 1.412 & 1.413 & 1.412 & 1.413 \\
LEVE & 1.043 & 1.044 & 1.044 & 1.045 \\
SIZE & 1.103 & 1.093 & 1.104 & 1.094 \\
YED1 & 3.573 & 3.363 & 3.614 & 3.401 \\
YED2 & 1.318 & 1.318 & 1.318 & 1.318 \\
REGUL & 1.008 & 1.008 & 1.018 & 1.018 \\
\hline
\end{tabular}

Table 7.5 Fixed-Effects estimation of the effect of institutional ownership on firm performance

This table reports the fixed effects estimation of effect of institutional ownership on firm performance. The sample consists of 1,176 firms (3,273 observations) listed on the Shanghai and Shenzhen stock exchanges over the period of 2001-2003. (1) Tobin's Q: (market value of equity + book value of long-term debt + book value of short-term debt)/book value of total assets. (2) ROA: the ratio of net profit before extraordinary items divided to the average book value of total assets. (3) INST: the ratio of the number of shares held by securities companies and investment funds to the total number of shares in issue. (4) INST_S: the ratio of the number of shares held by securities companies to the total number of shares in issue. (5) INST_F: the ratio of the number of shares held by investment funds to the total number of shares in issue. (6) STATEO: the ratio of the number of shares owned by the state and state-owned legal persons to the total number of shares in issue. (7) LPO: the percentage of total shares held by domestic corporations and other non-individual entities. I deduct the non-tradable shares held by securities companies from total legal-person shareholdings to avoid double count. (8) MAO: the percentage of stock owned by managers. (9) FORO: the percentage of shares held by foreign investors. (10) HERF_5: the average of the sum of squares of percentage of shares held by each top five shareholder. (11) LEVE: the ratio of the total value of debt by the book value of total assets. (12) TANG: the ratio of net fixed assets over total assets. (13) SIZE: the natural logarithm of firm's annual sales. (14) YED1: year dummy 1 that takes the value of 1 for year 2001, and zero otherwise. (15) YED2: year dummy 2 that takes the value of 1 for year 2002, and zero otherwise. Separate regressions were undertaken because STATEO and LPO are highly correlated with each other $(\beta=-0.828)$. White Statistics is the White test on heteroskadasticity that follows a chi-square distribution. $T$-values based on White's (1980) corrected standard errors are in parentheses. ${ }^{* * *},{ }^{* *}$ and ${ }^{*}$ denote significance at the 1 per cent, 5 per cent and 10 per cent level (two-tailed), respectively. 
Panel A The impact of institutional ownership on Tobin's Q

\begin{tabular}{lcccc}
\hline & Equation $(1)$ & Equation $(1)$ & Equation $(2)$ & Equation $(2)$ \\
\hline INST & $0.924^{* *}$ & $0.927^{* *}$ & & \\
& $(1.98)$ & $(2.20)$ & & \\
INST_S & & & 3.197 & 3.358 \\
& & & $(0.92)$ & $(0.83)$ \\
INST_F & & & $0.888^{* *}$ & $1.113^{* *}$ \\
& & & $(1.98)$ & $(2.02)$ \\
STATEO & $-0.422^{* * *}$ & & $-0.346^{* * *}$ & \\
& $(-8.74)$ & & $(-7.76)$ & \\
LPO & & & & $0.224^{* * *}$ \\
& & & & $(5.22)$ \\
MAO & 6.312 & $(5.74)$ & 7.714 & 8.736 \\
& $(0.82)$ & $(0.85)$ & $(1.01)$ & $(1.09)$ \\
FORO & 0.026 & 0.046 & 0.145 & 0.105 \\
& $(0.14)$ & $(0.24)$ & $(0.65)$ & $(0.47)$ \\
HERF_5 & $3.505^{* * * *}$ & $3.767^{* *}$ & $4.371^{* *}$ & $4.758^{* *}$ \\
& $(2.18)$ & $(2.31)$ & $(2.81)$ & $(3.04)$ \\
TANG & $-0.555^{* * *}$ & $-0.623^{* * *}$ & $-0.381^{* *}$ & $-0.434^{* *}$ \\
& $(-4.23)$ & $(-4.70)$ & $(-3.00)$ & $(-3.39)$ \\
LEVE & $0.130^{* *}$ & $0.143^{* *}$ & $0.130^{* *}$ & $0.177^{* *}$ \\
Observations & $(3.11)$ & $(3.38)$ & $(3.12)$ & $(1.82)$ \\
SIZE & $-0.030^{* *}$ & $-0.039^{* *}$ & $-0.053^{* *}$ & $-0.062^{* *}$ \\
YED1 & $(-2.19)$ & $(-1.93)$ & $(-2.43)$ & $(-2.80)$ \\
YED2 & yes & yes & yes & yes \\
CONS & yes & yes & yes & yes \\
& $2.316^{* * * *}$ & $2.317^{* * *}$ & $2.631^{* * *}$ & $2.643^{* * *}$ \\
& $(5.54)$ & $(5.48)$ & $(5.77)$ & $(5.71)$ \\
& 0.208 & 0.183 & 0.176 & 0.173 \\
& 2.003 & 1.992 & 1.908 & 1.876 \\
& $27.360^{* * *}$ & $23.720^{* * *}$ & $12.532^{* * *}$ & $13.162^{* * *}$ \\
& $387.899^{* * *}$ & $398.255^{* * *}$ & $168.332^{* * *}$ & $170.138^{* * *}$ \\
& 3273 & 3273 & 3273 \\
\hline
\end{tabular}


Panel B The impact of institutional ownership on ROA

\begin{tabular}{|c|c|c|c|c|}
\hline & Equation (1) & Equation (1) & Equation (2) & Equation (2) \\
\hline \multirow[t]{2}{*}{ INST } & $0.185^{* *}$ & $0.190^{* *}$ & & \\
\hline & $(2.02)$ & (1.98) & & \\
\hline \multirow[t]{2}{*}{ INST_S } & & & 0.059 & 0.073 \\
\hline & & & $(0.22)$ & $(0.28)$ \\
\hline \multirow[t]{2}{*}{ INST_F } & & & $0.524^{* *}$ & $0.544^{* *}$ \\
\hline & & & $(2.17)$ & $(2.25)$ \\
\hline \multirow[t]{2}{*}{ STATEO } & $-0.022^{* *}$ & & $-0.311^{* *}$ & \\
\hline & $(-1.98)$ & & $(-2.47)$ & \\
\hline \multirow[t]{2}{*}{ LPO } & & $0.007^{* *}$ & & $0.018^{* *}$ \\
\hline & & (1.98) & & $(2.25)$ \\
\hline \multirow[t]{2}{*}{ MAO } & 1.202 & 1.24 & 1.75 & 1.85 \\
\hline & $(0.56)$ & $(0.58)$ & $(0.67)$ & $(0.70)$ \\
\hline \multirow[t]{2}{*}{ FORO } & 0.033 & 0.033 & 0.046 & 0.043 \\
\hline & $(0.63)$ & $(0.64)$ & $(0.78)$ & $(0.72)$ \\
\hline \multirow[t]{2}{*}{ HERF_5 } & 0.141 & 0.179 & 0.499 & 0.458 \\
\hline & $(0.32)$ & $(0.40)$ & $(1.20)$ & $(1.10)$ \\
\hline \multirow[t]{2}{*}{ TANG } & $-0.200^{* * *}$ & $-0.194^{* * *}$ & $-0.166^{* * *}$ & $-0.161^{* * *}$ \\
\hline & $(-5.52)$ & $(-5.35)$ & $(-4.88)$ & $(-4.73)$ \\
\hline \multirow[t]{2}{*}{ LEVE } & $-0.163^{* * *}$ & $-0.162^{* * *}$ & $-0.196^{* * *}$ & $-0.195^{* * *}$ \\
\hline & $(-14.06)$ & $(-14.00)$ & $(-17.28)$ & $(-17.19)$ \\
\hline \multirow[t]{2}{*}{ SIZE } & $-0.015^{* *}$ & $-0.016^{* *}$ & $-0.012^{* *}$ & $-0.013^{* *}$ \\
\hline & $(-2.71)$ & $(-2.84)$ & $(-2.00)$ & $(-2.14)$ \\
\hline YED1 & yes & yes & yes & yes \\
\hline YED2 & yes & yes & yes & yes \\
\hline \multirow[t]{2}{*}{ CONS } & $0.172^{*}$ & $0.177^{*}$ & $0.135^{* *}$ & $0.137^{* *}$ \\
\hline & $(1.94)$ & (1.83) & (2.10) & $(2.12)$ \\
\hline Adj. $R^{2}$ & 0.185 & 0.194 & 0.174 & 0.184 \\
\hline D-W Statistic & 2.001 & 2.003 & 2.011 & 2.001 \\
\hline$F$-Statistic & $2.974^{* * *}$ & $3.261^{* * *}$ & $3.175^{* * *}$ & $3.863^{* * *}$ \\
\hline White Statistic & $55.874^{* * *}$ & $61.181^{* * *}$ & $50.218^{* * *}$ & $48.072^{* * *}$ \\
\hline Observations & 3273 & 3273 & 3273 & 3273 \\
\hline
\end{tabular}


H1 states that institutional ownership held by securities companies and investment funds is associated with firm performance. This is a preliminary check on whether the aggregate institutional ownership affects firm performance. The coefficients of variable INST in Tobin's Q and ROA regressions are all positive with $t$-values significant at the 5 per cent level. The results suggest that aggregate institutional ownership of investment funds and securities companies has a significant and positive impact on firm performance.

Consistent with H2, all coefficients of variable INST_S are positive, but do not bear statistical significance both in Tobin's $\mathrm{Q}$ and ROA regressions. This finding suggests that securities companies' shareholdings are not significantly related to firm performance. This result suggests that securities companies' shareholdings do not have a significant impact on firm performance, which could reflect problems like conflicts of interest and poor corporate governance that trouble securities companies. Alternatively, it might be simply because securities companies do not view active participation into corporate decisions a valueincreasing choice according to a cost-benefit analysis.

The hypothesis that firm performance is positively related to the percentage of ownership held by investment funds (H3) is supported by the positive and significant coefficients for variable INST_F. The result is consistent with the notion that investment funds have the incentive and the ability to take part in the corporate governance on behalf of their investors. Indeed, recent anecdotal evidence also confirms this finding.

Overall, these findings indicate that investment funds and securities companies have played different roles in corporate governance. That is, investment funds have a positive impact on firm performance, while securities companies have no such impact. It also suggests that the positive and statistically significant effect of the aggregate institutional ownership in $\mathrm{H} 1$ is mainly driven by the positive effect of investment funds' ownership.

Now I turn to the results for control variables. As in prior studies (e.g., Xu and Wang, 1999; Qi et al., 2000; Chen, 2001; Sun and Tong, 2003), state ownership variable has negative significant coefficients in all regressions, suggesting that state ownership is inefficient and detrimental to firm performance. Too big state ownership implies that too much political 
interference from the government forces companies to deviate from profit-maximising behaviour, leading to relatively poor performance. Therefore, ownership (mainly state ownership) reforms in China are expected to not only result in a lower level of political interference in firm decision-making, but also be conducive to firm performance.

Consistent with the results of Qi et al. (2000), Chen (2001), and Sun and Tong (2003), legal person ownership exhibits a significantly positive impact on both Tobin's $Q$ and ROA. Legal person shareholders in China are not only motivated, but also better equipped, with powers to control and monitor the management (Chiou and Lin, 2005).

Consistent with Gul and Zhao (2000), managerial ownership has no impact on firm performance. Since their incomes are not correlated to firm profitability (Shirai, 2004), managers have little incentive to improve firm performance. Although some board directors and CEOs hold shares in their companies, the amount of holdings tends to be too small to make shareholdings a powerful incentive device.

As in Qi et al. (2000) and Sun and Tong (2003), foreign ownership has no impact on performance. It is plausible that foreign ownership is diffused and small ${ }^{53}$ and foreign shareholders are too insignificant to influence a firm's management.

Supporting the results of Xu and Wang (1999), Wang et al. (2004a), and Chiou and Lin (2005), ownership concentration variable HERF_5 has positive coefficients in all regressions, although only those in Tobin's $Q$ regressions bear statistically significance. This finding suggests that an overly dispersed ownership structure may not be the best way to improve economic efficiency of the public sector (Chen, 2001). Under a weak legal and regulatory system, having a few large shareholders on a relatively equal footing may improve corporate governance and prevent misbehaviour by a dominant shareholder (Wang et al., 2004a), thereby reducing the expropriation of minority shareholders by large shareholders.

${ }^{53}$ The average foreign ownership in the period of $2000-2002$ is $2.27 \%$ in Table 7.2 . 
As in Sun and Tong (2003), I find a mixed result on the effect of leverage on firm performance. Specifically, leverage has a positive impact on Tobin's Q, which is consistent with the capital structure theory, but it has a negative impact on ROA, which indicates that firms with higher leverage may have heavier interest burdens and their profitability is eroded by the higher interest expenses.

Otherwise, I find that large firms and firms with higher tangible asset intensity tend to have a poorer performance (measured in both $\mathrm{Q}$ and ROA) than other firms. The former finding is consistent with the results of Sun et al. (2002), Hovey et al. (2003) and Sun and Tong (2003), while the latter finding is the same as Tian (2001) and Wang (2003). Large firms in China are often state-owned and so may suffer from more government bureaucracy and/or agency problems.

\subsection{Robustness checks}

In this section, I perform some robustness checks to examine the sensitivity of the results.

\subsubsection{Endogeneity issues - a simultaneous-equation analysis}

\subsubsection{Research design}

Though my results provide strong evidence that firm performance is positively related to institutional ownership, one could argue that investment funds only invest in listed companies that are well managed and profitable. That is, the causality may run from firm performance to institutional ownership.

Morck et al. (1988) and McConnell and Servaes (1990) treat ownership structure as exogenous in exploring the relation between ownership structure and firm performance. Demsetz (1983) argue that ownership structure is endogenously determined in equilibrium. Demsetz and Lehn (1985) show that ownership concentration is determined by several industry and firm-specific factors, and there is no significant relationship between ownership concentration and accounting returns. Furthermore, Kole (1996) provides evidence of a reversal of causality in the ownership-firm performance relation, suggesting 
that firm performance could be a determinant of ownership structure rather than being determined by ownership structure. Revisiting the Demsetz and Lehn's (1985) classic study, Demsetz and Villaonga (2001) find that ownership concentration (the fraction of shares owned by the five largest shareholdings and fraction of shares owned by management) has no impact on $\mathrm{Q}$, but $\mathrm{Q}$ negatively affects ownership concentration (the fraction of shares owned by management only) using a two-stage least-squares (2SLS) method. Zhang (2000) shows that ownership structure of listed Chinese companies after IPO can change according to their performance and other market conditions.

Similarly, an important issue to consider when investigating the relation between firm performance and institutional ownership is the endogeneity of institutional ownership. Indeed, the interview results have provided evidence that investment funds consider firm performance as the main factor that affects investment decisions. Following the literature, I identify the following factors that may determine financial institutional ownership:

Growth opportunities (GROWTH): Companies with high growth opportunities can attract more financial institutions (Dan, 2005), thus growth opportunity is expected to have a positive impact on institutional ownership. Growth Opportunities are proxied by the annual growth of sales over the period 2001-2003.

Liquidity (LIQU): Di (2004) argues that financial institutions prefer to invest in companies with large tradable shareholdings and market capitalization. Indeed, Jing (2004) reports that out of the 20 top portfolio companies of investment funds in 2003, 13 companies were among the top 20 companies with the largest market capitalisation. According to the principal of "one share, one vote," the more tradable shares, the more voting rights, and the closer the firm monitoring by financial institutions as the representatives of tradable shareholders. Thus, companies of a higher proportion of tradable shares are expected to have more financial institutional ownership.

Leverage (LEVE): Leverage reflects the possibility that creditors provide some of the monitoring of management that otherwise would have come from equity holders. The more a firm's debt, the closer the firm monitoring by creditors, reducing the need for institutional 
monitoring of the firm. Grier and Zychowicz (1994) find a negative relationship between institutional ownership of a firm and the leverage. Leverage is the ratio of the firm's book value of debt divided by the book value of total assets.

Firm Size (SIZE): A positive relation between firm size and institutional ownership may be expected due to legal and liquidity reason. As mentioned earlier, the regulations in China limit investment fund to invest no more than 10 per cent of its total funds in one listed company and its holdings of that company should not exceed 10 per cent of that company's total shares, thereby driving funds to larger companies. Furthermore, larger firms offer greater trading liquidity to institutions (Duggal and Millar, 1999). I use the natural logarithm of a firm's annual sales as the proxy of the firm size in this model.

Ownership concentration (HERF_5): High ownership concentration of state and legal person shares may make the monitoring afforded by financial institutions ineffective (Tenev et al., 2002). Thus, I expect a negative relation between ownership concentration and institutional ownership. Herfindahl index (HERF_5) is calculated as the average of the sum of squares of percentage of shares held by each top five shareholder.

Year dummy (YED): Institutional ownership in listed companies changes with time. Two year dummies are therefore included. YED1 takes the value of 1 for year 2001, and zero otherwise. YED2 takes the value of 1 for year 2002, and zero otherwise.

Regulatory status (REGUL): Demsetz and Lehn (1985) find a negative relation between institutional ownership concentration and the presence of regulatory monitoring. China regulates utilities, energy, and telecommunication firms (Sun and Tong, 2003). I use a dummy variable called REGUL with the value 1 for a regulated firm and the value of zero otherwise.

Combing all the factors together, the third equation is formulated to control for the endogeneity of institutional shareholdings held by securities companies and/or investment funds. As $\mathrm{H} 1$ is an exploratory test, here I focus on $\mathrm{H} 2$ and $\mathrm{H} 3$. 


$$
\mathrm{INST}_{-} \mathrm{S}_{i t}\left(\mathrm{INST}_{-} \mathrm{F}_{i t}\right)=\delta_{1}+\delta_{2} \text { Tobin's } \mathrm{Q}_{i t}\left(\mathrm{ROA}_{i t}\right)+\delta_{3} \mathrm{Z}_{i t}+\varepsilon_{3 i t}
$$

Where $\delta_{\mathrm{i}}$ represents coefficient, $\varepsilon$ is an error term with a mean of zero and controls for omitted variables, such as policy influence and preferences of fund managers. $Z_{i t}$ contains GROWTH, LIQU, LEVE, SIZE, HERF_5, YED1, YED2, and REGUL, which are defined above.

I transform equations (2) in section 7.3.4 into the fourth equation without lagging the independent variables, and then estimate the following system of simultaneous-equation models to test the endogeneity of ownership.

$$
\begin{aligned}
& \text { INST_S }_{i t}\left(\mathrm{INST} \_\mathrm{F}_{i t}\right)=\delta_{1}+\delta_{2} \text { Tobin's } \mathrm{Q}_{i t}\left(\mathrm{ROA}_{i t}\right)+\delta_{3} \mathrm{Z}_{i t}+\varepsilon_{3 i t} \\
& \text { Tobin's } \mathrm{Q}_{i t}\left(\mathrm{ROA}_{i t}\right)=\lambda_{1}+\lambda_{2} \mathrm{INST}_{-} \mathrm{S}_{i t}+\lambda_{3} \mathrm{INST}_{-} \mathrm{F}_{i t}+\lambda_{4} \mathrm{C}_{i t}+\varepsilon_{4 i t}
\end{aligned}
$$

\subsubsection{Correlations}

Table 7.6 shows the correlation matrix for the sample used here. The correlations that should be noted are the -0.852 correlation between state ownership variable STATEO and legal person variable LPO. None of the remaining variables is correlated to an extent that merits attention. As previous, STATEO and LPO cannot be included in the estimation at the same time due to high correlation.

\subsubsection{Regression results}

Table 7.7 reports the results of 2SLS. Panel A focuses on the impact of firm performance on securities companies' shareholdings, while Panel B focuses on the impact of firm performance on investment funds' shareholdings.

First focus on 2SLS estimates from the firm performance equations. Panel A shows that all coefficients of INST_S are positive but insignificant in the performance regressions. These are consistent with the results based on the single-equation model reported in Table 7.5. Additionally, the coefficients of ROA in the ownership equations are significantly positive, while those of Tobin's $\mathrm{Q}$ are not significant. This finding suggests that accounting return 
affects the institutional shareholdings of securities companies, but their shareholdings do not influence firm performance measured in market and accounting terms.

As for the effect of investment funds' shareholdings, all coefficients of INST_F in Panel B are significantly positive, which is consistent with the results derived from the singleequation model. Additionally, in the ownership equations, the coefficients of ROA are significantly positive, while those of Tobin's Q are not significant. Hence, I find some support for the reversed causality that runs from firm performance to ownership.

As far as the control variables of financial institutional ownership are concerned, firms with high growth opportunity (GROWTH) tend to have more institutional ownership, while firms with high leverage (LEVE) tend to have less institutional ownership. No other variables are found to be significant.

In summary, the results on the effects of financial institutional ownership on firm performance appear to be robust to a simultaneous-equation estimation and so there is no evidence that the results suffer from a bias caused by the endogeneity of ownership with respect to firm performance. Second, I do find evidence that investment funds and securities companies choose to invest firms with good accounting performance. 


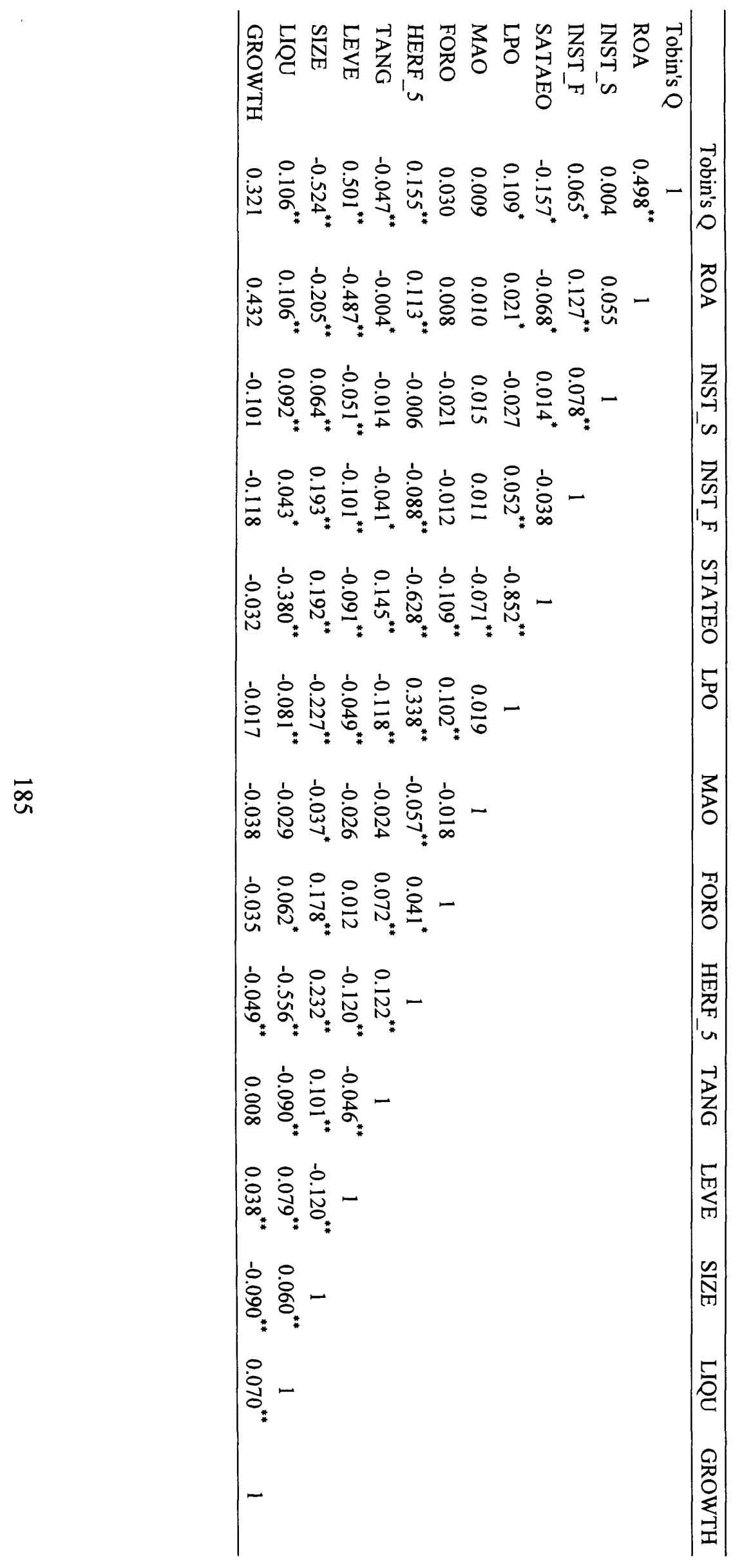

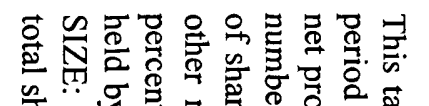

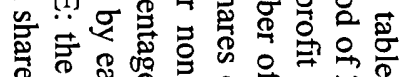

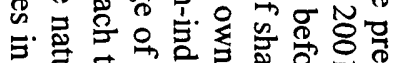
. 员

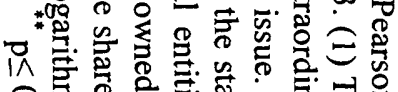

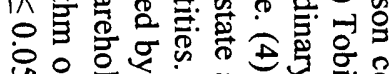

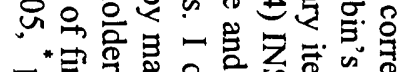

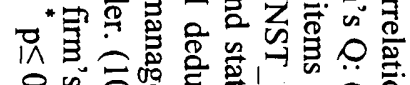
ㄴ

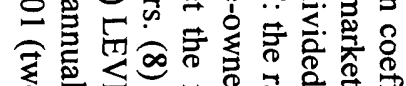

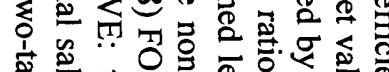

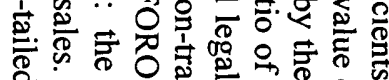
党

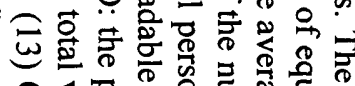

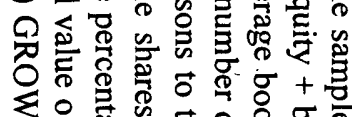

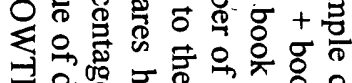

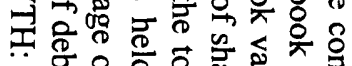

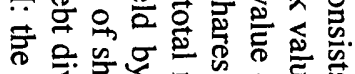

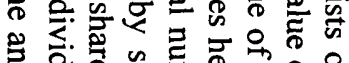

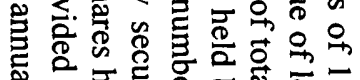

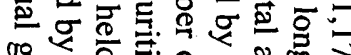

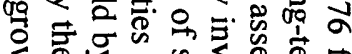

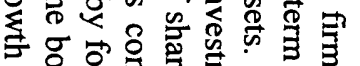

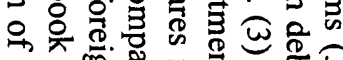

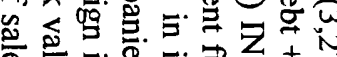

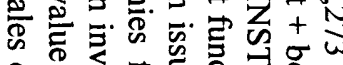

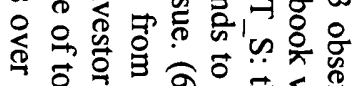

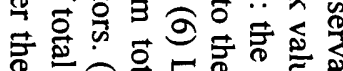
兽. 응

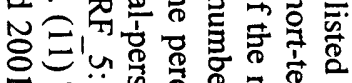

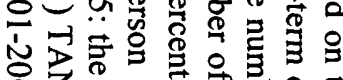

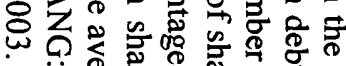

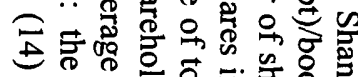

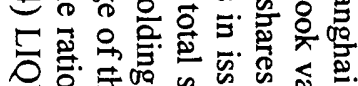

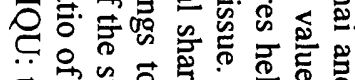

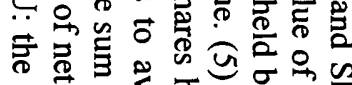

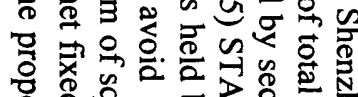

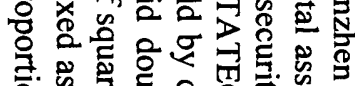

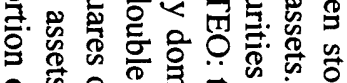

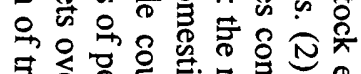

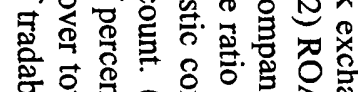

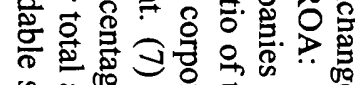

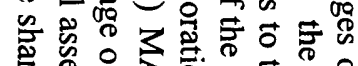

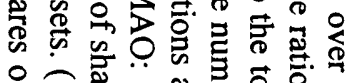

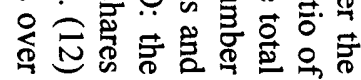




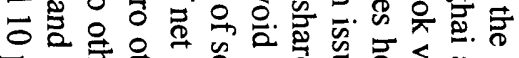

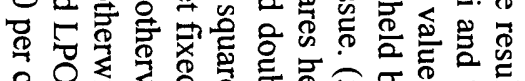

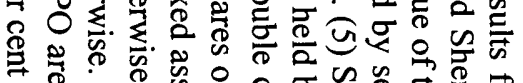

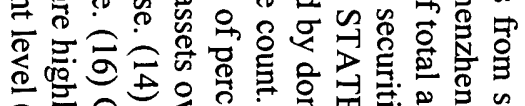

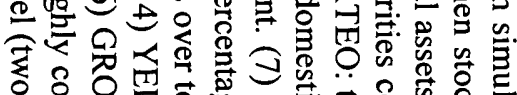

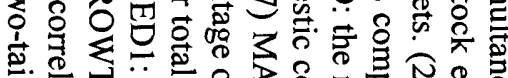

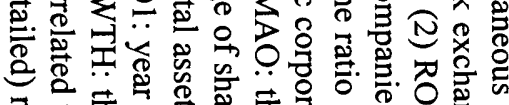

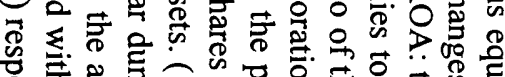

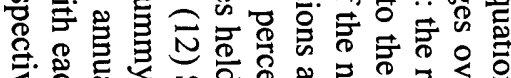

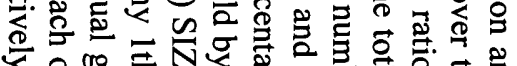

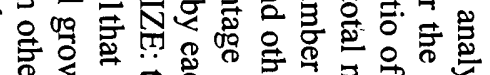

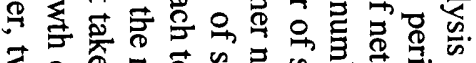

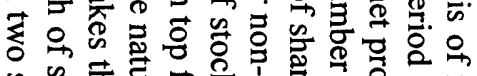

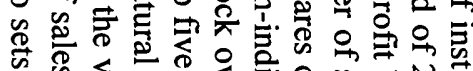

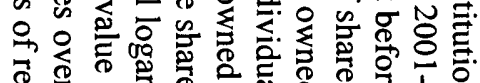

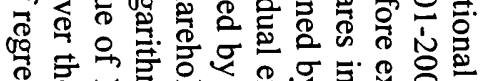

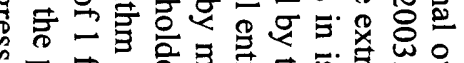

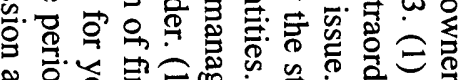

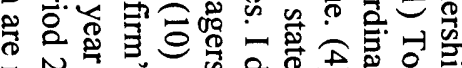
శึ

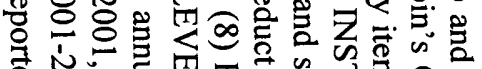

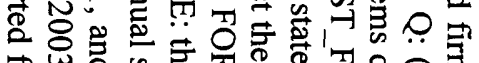

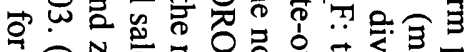

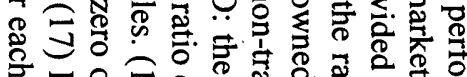

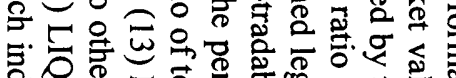

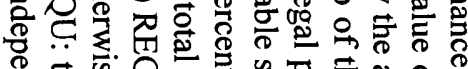

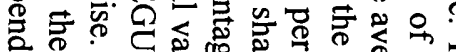

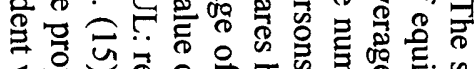

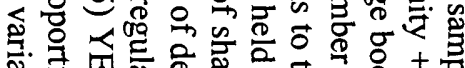

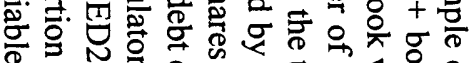

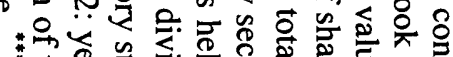

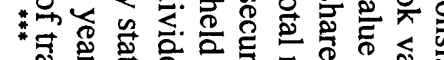

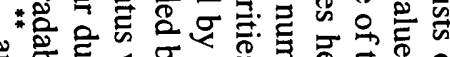

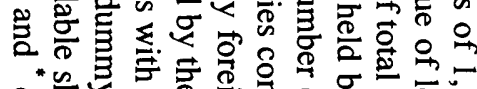

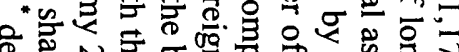

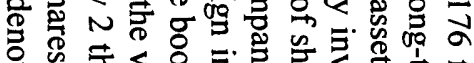

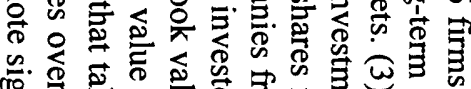

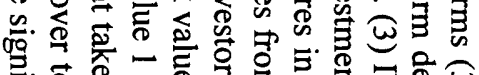

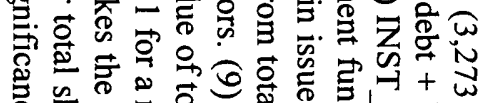

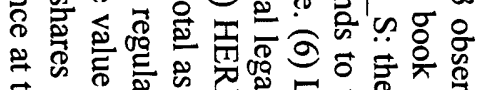

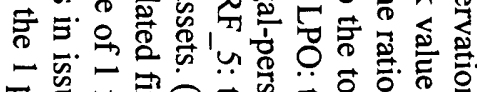

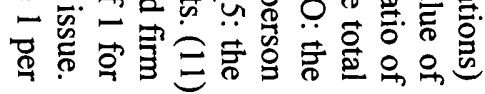




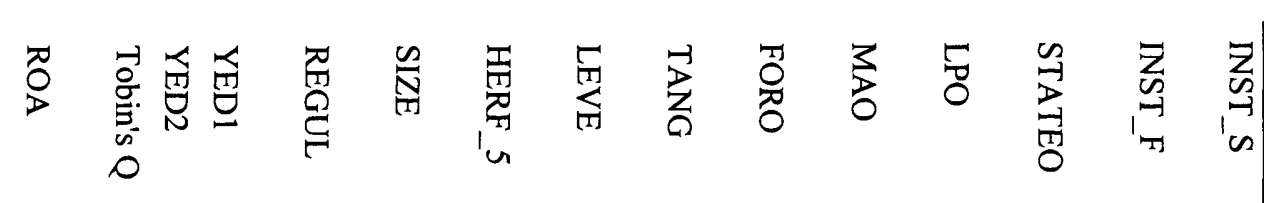

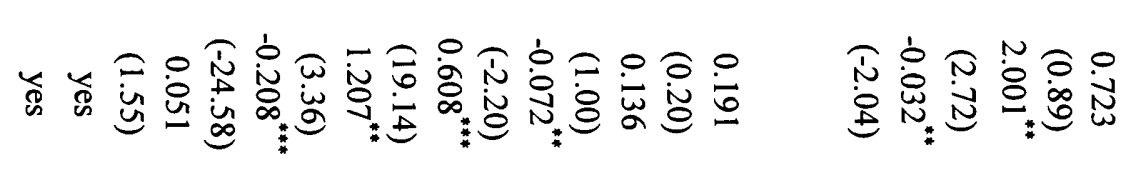

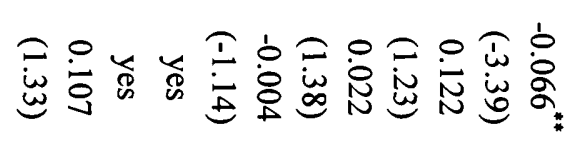

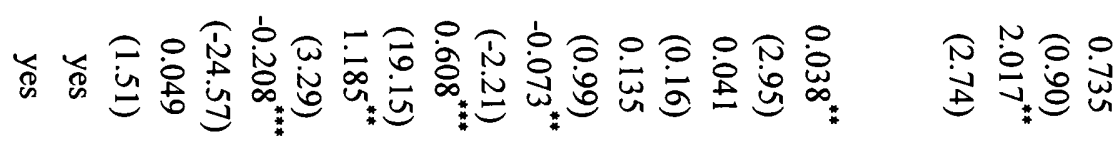

$\bar{\infty}$

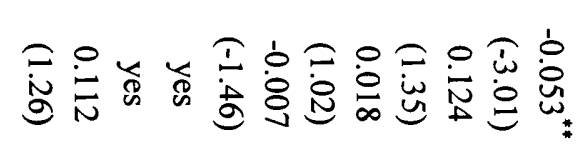

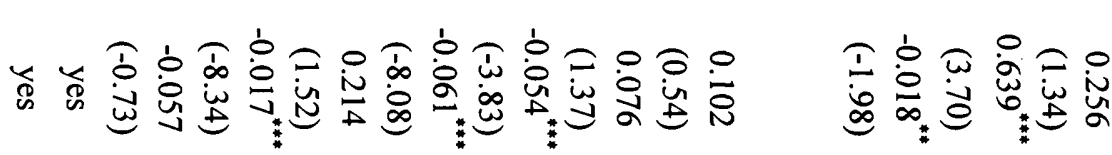

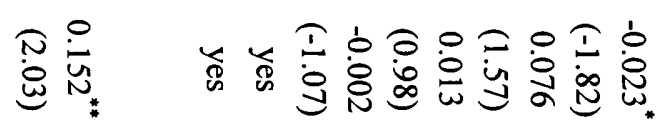

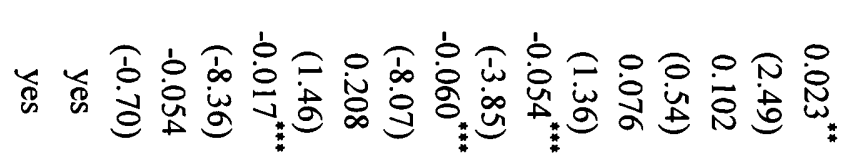

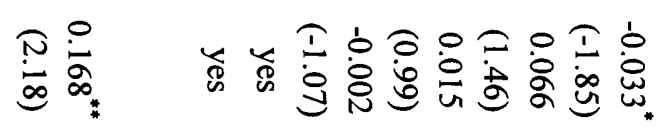




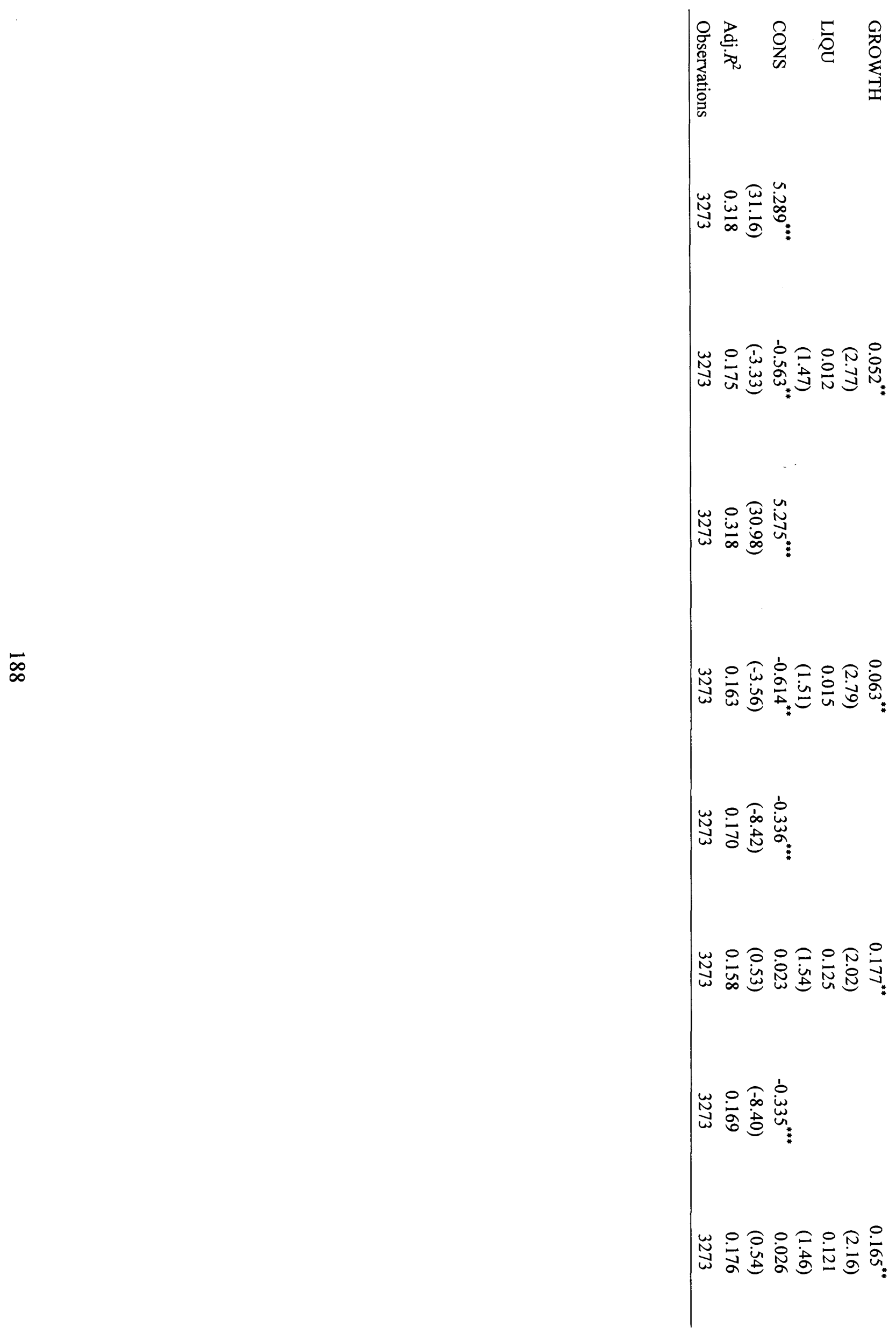




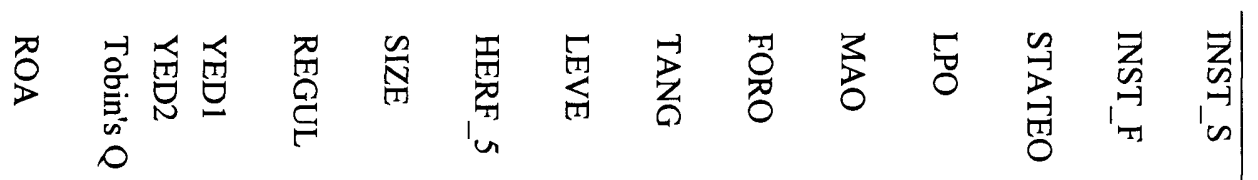

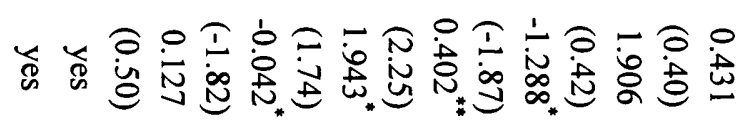

$$
\begin{aligned}
& \text { กิ } \\
& \text { 点 }
\end{aligned}
$$

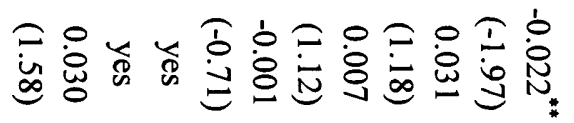

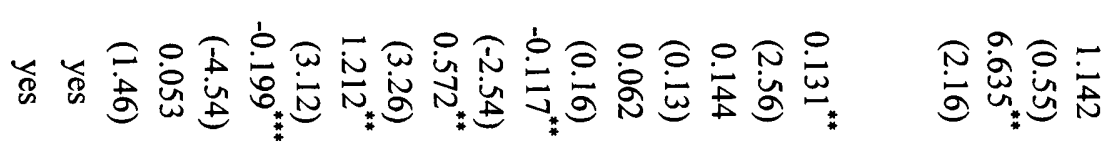

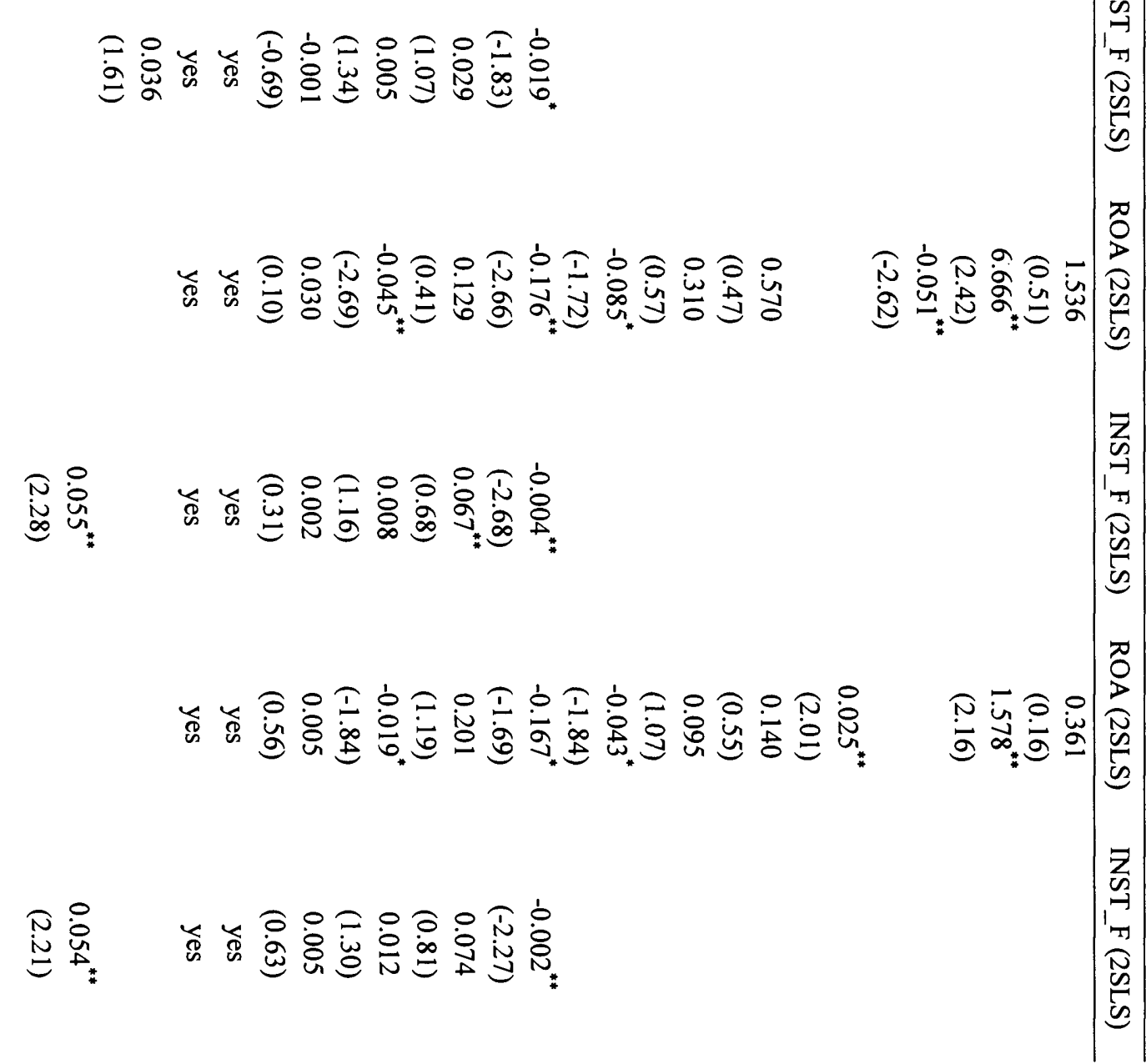

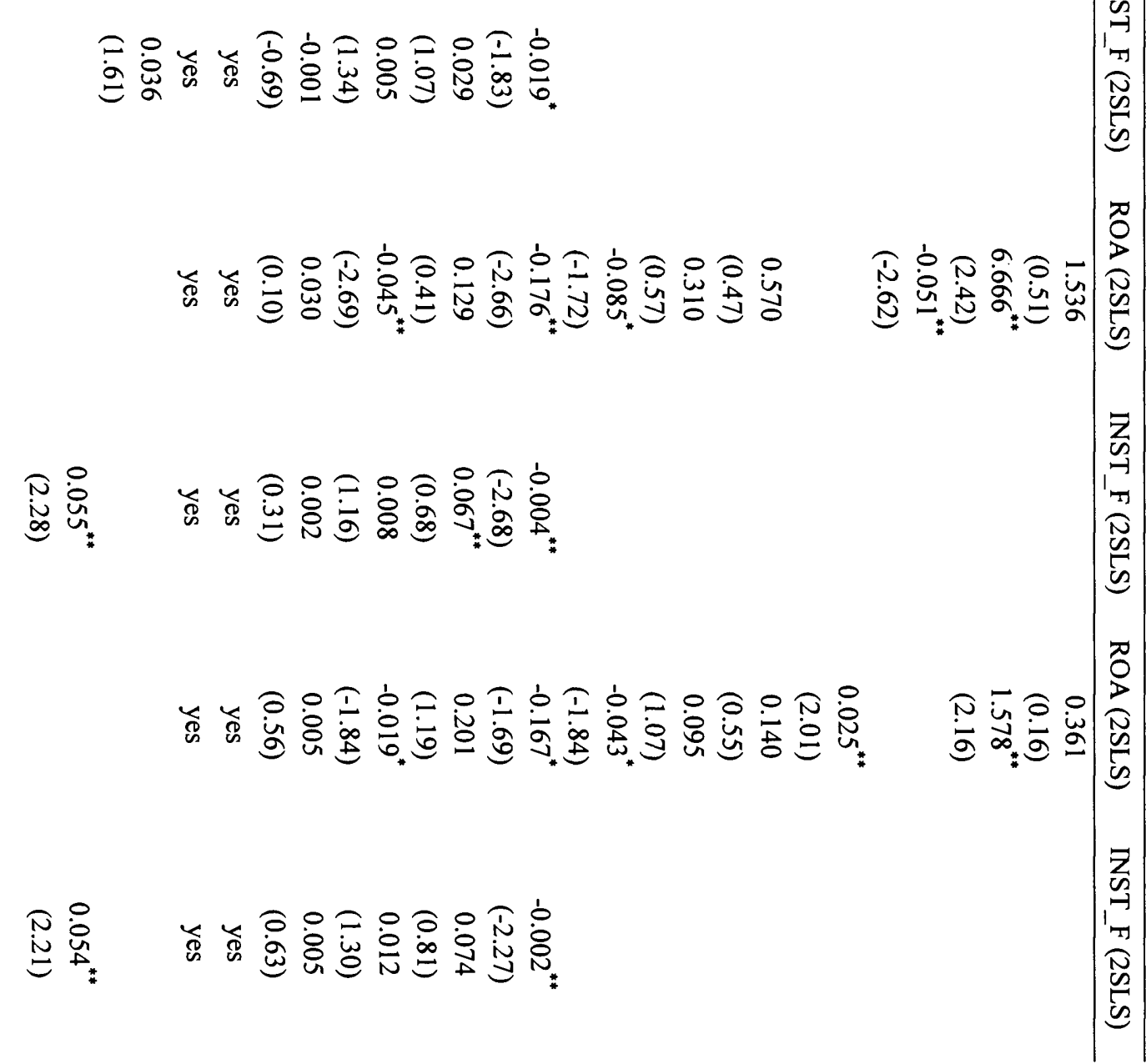

$$
\begin{aligned}
& \varpi
\end{aligned}
$$




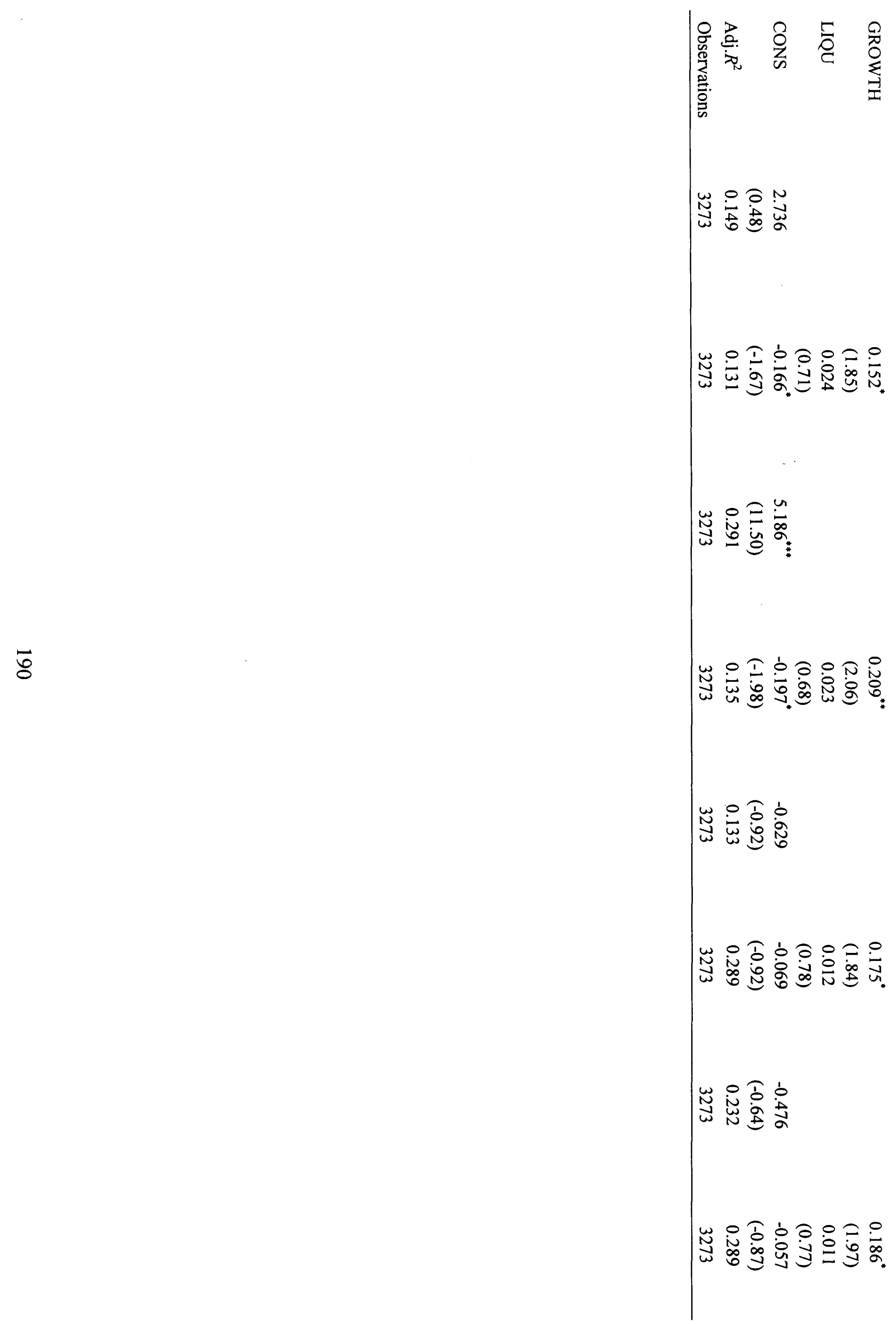




\subsubsection{Estimation in changes}

This section uses estimation in changes to test whether changes in financial institutional shareholdings are associated with changes in firm performance. Estimation in changes can often lead to more robust results as such estimation can help to reduce measurement errors arising from omitted variables. Taking the first differences of dependent variables and lagged independent variables means that 182 firms with only one or two observations in the sample period have to be lost. As a result, 994 firms (1,988 observations) are included in the estimation of Equations (1)-(2) in changes. The results are reported in Table 7.8.

Comparing the new results and the results reported in Table 7.5, it appears that increase in shareholdings of investment funds over time leads to better firm performance (both in market and accounting terms), while increase in shareholdings of securities companies has no such impact. The results are consistent with the hypotheses 2 and 3.

\section{Table 7.8 The effect of institutional ownership change on firm performance change}

This table reports the effect of change in institutional ownership on change in firm performance. (1) DTobin's $\mathrm{Q}$ : change in the ratio calculated as the sum of market value of equity, book value of long-term debt and book value of short-term debt by book value of total assets. (2) DROA: change in the ratio calculated as net profit before extraordinary items by the average book value of total assets. (3) DINST: change in the ratio of the number of shares held by securities companies and investment funds to the total number of shares from the previous year. (4) DINST_S: change in the ratio of the number of shares held by securities companies to the total number of shares from the previous year. (5) DINST_F: change in the ratio of the number of shares held by investment funds to the total number of shares from the previous year. (6) DSTATEO: change in the ratio of the number of shares owned by the state and state-owned legal persons to the total number of shares from the previous year. (7) DLPO: change in the percentage of total shares held by domestic corporations and other non-individual entities from the previous year. I deduct the non-tradable shares held by securities companies from total legal-person shareholdings to avoid double count. (8) DMAO: change in the percentage of stock owned by managers from the previous year. (9) DFORO: change in the percentage of shares held by foreign investors from the previous year. (10) DHERF_5: change in ratio calculated as the average of the sum of squares of percentage of shares held by each top five shareholder. (11) DLEVE: change in the ratio calculated as the total value of debt by the book value of total assets. (12) DTANG: change in the ratio of net fixed assets over total assets. (13) DSIZE: change in the natural logarithm of firm's annual sales. (14) YED1: year dummy 1 that takes the value of 1 for year 2001, and zero otherwise. (15) YED2: year dummy 2 that takes the value of 1 for year 2002, and zero otherwise. Because STATEO and LPO are highly correlated with each other, two sets of regression are reported for each independent variable. ${ }^{* * *},{ }^{* *}$ and ${ }^{*}$ denote significance at the 1 per cent, 5 per cent and 10 per cent level (two-tailed) respectively. 
Panel A The impact of change in institutional ownership on change in Tobin's $Q$

\begin{tabular}{|c|c|c|c|c|}
\hline & Equation (1) & Equation (1) & Equation (2) & Equation (2) \\
\hline \multirow[t]{2}{*}{ DINST } & $0.953^{*}$ & $0.988^{* *}$ & & \\
\hline & (1.88) & $(1.98)$ & & \\
\hline \multirow[t]{2}{*}{ DINST_S } & & & 1.05 & 1.078 \\
\hline & & & $(1.20)$ & $(1.23)$ \\
\hline \multirow[t]{2}{*}{ DINST_F } & & & $1.722^{* *}$ & $1.812^{* *}$ \\
\hline & & & $(2.32)$ & $(2.40)$ \\
\hline \multirow[t]{2}{*}{ DSTATEO } & $-0.420^{* * *}$ & & $-0.122^{* *}$ & \\
\hline & $(-8.23)$ & & $(-2.09)$ & \\
\hline \multirow[t]{2}{*}{ DLPO } & & $0.274^{* *}$ & & $0.111^{* *}$ \\
\hline & & $(2.76)$ & & $(1.99)$ \\
\hline \multirow[t]{2}{*}{ DMAO } & 4.307 & 4.611 & 6.019 & 6.548 \\
\hline & $(1.02)$ & $(1.24)$ & $(0.44)$ & $(0.48)$ \\
\hline \multirow[t]{2}{*}{ DFORO } & 0.112 & 0.146 & 0.179 & 0.166 \\
\hline & $(0.45)$ & $(0.64)$ & $(0.82)$ & $(0.76)$ \\
\hline \multirow[t]{2}{*}{ DHERF_5 } & $3.411^{*}$ & $3.467^{*}$ & $0.498^{*}$ & $0.662^{*}$ \\
\hline & $(1.87)$ & (1.94) & $(1.78)$ & $(1.82)$ \\
\hline \multirow[t]{2}{*}{ DTANG } & $-0.312^{* *}$ & $-0.327^{* *}$ & $-0.349^{* *}$ & $-0.351^{* *}$ \\
\hline & $(-2.09)$ & $(-2.17)$ & $(-2.14)$ & $(-2.15)$ \\
\hline \multirow[t]{2}{*}{ DLEVE } & $0.131^{* *}$ & $0.133^{* *}$ & $1.121^{* * *}$ & $1.122^{* * *}$ \\
\hline & $(3.02)$ & $(3.17)$ & (21.68) & $(21.71)$ \\
\hline \multirow[t]{2}{*}{ DSIZE } & $-0.030^{* *}$ & $-0.039^{*}$ & $-0.024^{* *}$ & $-0.023^{* *}$ \\
\hline & $(-2.01)$ & $(-1.93)$ & $(-2.01)$ & $(-2.03)$ \\
\hline YED1 & yes & yes & yes & yes \\
\hline YED2 & yes & yes & yes & yes \\
\hline \multirow[t]{2}{*}{ CONS } & $3.232^{* * *}$ & $3.317^{* * *}$ & $0.138^{* * *}$ & $0.141^{* * *}$ \\
\hline & $(8.12)$ & $(8.43)$ & $(9.77)$ & $(10.46)$ \\
\hline Adj. $R^{2}$ & 0.251 & 0.243 & 0.336 & 0.333 \\
\hline D-W Statistic & 1.788 & 1.804 & 1.879 & 1.915 \\
\hline$F$-Statistic & $37.160^{* * *}$ & $35.120^{* * *}$ & $27.147^{* * *}$ & $28.613^{* * *}$ \\
\hline White Statistic & $377.166^{* * *}$ & $369.125^{* * *}$ & $178.215^{* * *}$ & $169.652^{* * *}$ \\
\hline Observations & 1988 & 1988 & 1988 & 1988 \\
\hline
\end{tabular}


Panel B The impact of change in institutional ownership on change in ROA

\begin{tabular}{|c|c|c|c|c|}
\hline & Equation (1) & Equation (1) & Equation (2) & Equation (2) \\
\hline \multirow[t]{2}{*}{ DINST } & $0.109^{*}$ & $0.115^{* *}$ & & \\
\hline & $(1.75)$ & $(2.04)$ & & \\
\hline \multirow[t]{2}{*}{ DINST_S } & & & 0.082 & 0.081 \\
\hline & & & $(0.22)$ & $(0.22)$ \\
\hline \multirow[t]{2}{*}{ DINST_F } & & & $0.177^{*}$ & $0.162^{*}$ \\
\hline & & & $(1.76)$ & $(1.80)$ \\
\hline \multirow[t]{2}{*}{ DSTATEO } & $-0.078^{*}$ & & $-0.443^{* *}$ & \\
\hline & $(-1.89)$ & & $(-2.18)$ & \\
\hline \multirow[t]{2}{*}{ DLPO } & & $0.018^{* *}$ & & $0.157^{*}$ \\
\hline & & $(2.42)$ & & (1.87) \\
\hline \multirow[t]{2}{*}{ DMAO } & 1.667 & 1.704 & 0.116 & 0.124 \\
\hline & $(0.86)$ & $(0.96)$ & $(0.11)$ & $(0.12)$ \\
\hline \multirow[t]{2}{*}{ DFORO } & 0.123 & 0.133 & 0.841 & 0.843 \\
\hline & $(0.87)$ & $(0.92)$ & $(0.90)$ & $(0.91)$ \\
\hline \multirow[t]{2}{*}{ DHERF_5 } & 0.176 & 0.179 & 0.590 & 0.588 \\
\hline & $(0.42)$ & $(0.47)$ & $(1.24)$ & $(1.22)$ \\
\hline \multirow[t]{2}{*}{ DTANG } & $-0.334^{*}$ & $-0.339^{*}$ & $-0.264^{* * *}$ & $-0.263^{* * *}$ \\
\hline & $(-1.93)$ & $(-1.94)$ & $(-3.80)$ & $(-3.79)$ \\
\hline \multirow[t]{2}{*}{ DLEVE } & $-0.112^{* * *}$ & $-0.121^{* * *}$ & $-0.279^{* * *}$ & $-0.263^{* * *}$ \\
\hline & $(-8.03)$ & $(-8.12)$ & $(-12.67)$ & $(-12.48)$ \\
\hline \multirow[t]{2}{*}{ DSIZE } & $-0.215^{* *}$ & $-0.221^{* *}$ & $-0.022^{*}$ & $-0.022^{*}$ \\
\hline & $(-3.21)$ & $(-3.34)$ & $(-1.84)$ & $(-1.85)$ \\
\hline YED1 & yes & yes & yes & yes \\
\hline YED2 & yes & yes & yes & yes \\
\hline \multirow[t]{2}{*}{ CONS } & 0.134 & 0.138 & $0.165^{* *}$ & $0.170^{* *}$ \\
\hline & $(1.44)$ & $(1.48)$ & $(2.74)$ & $(2.95)$ \\
\hline Adj. $R^{2}$ & 0.215 & 0.198 & 0.159 & 0.163 \\
\hline D-W Statistic & 1.914 & 2.012 & 2.012 & 2.124 \\
\hline$F$-Statistic & $27.168^{* * *}$ & $27.229^{* * *}$ & $30.521^{* * *}$ & $31.528^{* * *}$ \\
\hline White Statistic & $67.174^{* * *}$ & $65.223^{* * *}$ & $68.521^{* * *}$ & $70.185^{* * *}$ \\
\hline $\mathrm{N}$ & 1988 & 1988 & 1988 & 1988 \\
\hline
\end{tabular}




\subsubsection{Other checks}

I also conduct several other checks.

First, I run all the regressions without lagging the independent variables. The use of lagged ownership variables rests on the assumption that institutional ownership may take time to exert influences on firm performance. I tested for this relationship by re-estimating the models using the contemporaneous values of ownership and other explanatory variables.

Second, I replace the Tobin's Q and ROA with return on equity (ROE), which is defined as net profit before extraordinary items divided by the average of owners' equity during the year.

Third, I replace the Tobin's Q and ROA with market-to-book ratio (MBR), which is the ratio of share prices on the last trading day of each year times the number of total outstanding shares over the book value of equity.

Fourth, I replace INST with a dummy variable INDU that takes the value of 1 when there is a securities company or an investment fund in the top ten shareholders of a listed company, and zero otherwise.

In each of the above, I re-run models (1)-(2) and obtain results very similar to the results of the main lagged models reported in Table 7.5. The new results are reported in the Appendixes 2, 3, 4, and 5, respectively. Therefore, the results on the effect of financial institutional ownership on firm performance appear to be robust.

\subsection{Conclusion}

Using a sample consisting of 1,176 companies (3,273 observations) listed on the Shanghai and Shenzhen stock exchanges over a period 2001-2003, I find that: (1) investment funds have a positive impact on firm performance and accounting performance influences their shareholdings; (2) the shareholdings of securities companies have no significant impact on firm performance. The results disprove the general perception that financial institutions in China play no role in corporate governance and indicate that different financial institutions have differing impacts on firm performance. 
The policy implications of the results are: (1) the regulatory efforts in promoting the development of investment funds as institutional shareholders seem to be beneficial to corporate governance and performance and so should be carried on; (2) future reform might need to focus on developing the role of securities companies in corporate governance.

Finally, I acknowledge that the results may be tempered by two limitations. The first is the measurement of Tobin's $Q$ in an emerging market like China with segmented ownership (e.g., publicly tradable and non-publicly-tradable shares) despite my careful treatment. Second, in China, only the institutional ownership in top ten shareholders is disclosed. Information on other scattered institutional shareholdings is not available. This may slightly underestimate the effect of financial institutional ownership. Thus, the results should be interpreted with caution. 


\section{Chapter Eight \\ Shareholder Activism: The Case of China Merchants Bank}

\subsection{Introduction}

The previous two chapters explore the role of financial institutions in corporate governance with interviews and secondary data analysis. As an exploratory tool, the interviews suggest that most securities companies are passive shareholders, while some active investment funds have played a role in helping listed companies standardise their practices, raise funds and establish good images in stock markets. To analyse this role quantitatively, Chapter Seven examines the relationship between firm performance and institutional shareholdings and finds that shareholdings of investment funds have a positive relationship with firm performance, while securities companies have no such significant effect.

To further crystallise the role of financial institutions in corporate governance, this chapter focuses on a specific case, in which fund managers took a collective action to challenge an issue proposal of their portfolio company. Such qualitative research is important as it enhances the understanding of the practice that Chinese financial institutions intervene in corporate issues in a real-life context. This case study also provides an opportunity to examine the interactions between financial institutions and other corporate governance mechanisms and serves as a mirror to highlight the problems in corporate governance and effectiveness of other corporate governance mechanisms.

The remainder of this chapter is organised as follows: Section 2 presents research method and data sources. Section 3 provides an introduction of background of China Merchants Bank (CMB). Section 4 depicts the dispute between $\mathrm{CMB}$ and financial institutions. Section 5 presents the discussion, and Section 6 concludes.

\subsection{Research method and data sources}

Case studies are well-suited to studying areas where reliable datasets are largely unavailable (Mar and Young, 2001), and also appropriate when a phenomenon is not wellunderstood (Yin, 1981). Because it is only a recent phenomenon in China that financial 
institutions attempt to influence corporate issues of listed companies, the role of financial institutions in corporate governance is not well recognised, and some odd scraps of relevant reports or news can only be available after $2000 . .^{54}$

Interviewing is obviously one means of collecting data in case study research. Indeed, to Yin (1993) the interview is the cornerstone of case study research. At the same time, it is also recognised that the ability to collect data from several sources, including interviews, archival records, documents, non-participant observation and so on (David, 2004).

I undertook ten interviews over the period from July to September 2004. Five face-to-face interviews were held in Beijing as the five interviewees (interviewees "A," "F," "G," "I," and "J") worked in Beijing. Five other interviewees (interviewees "B," "C," "D," "E," and " $\mathrm{H}$ ") worked outside Beijing and they were interviewed by telephone. An interview questionnaire (see interview schedule in the Appendix 6) was emailed to all interviewees beforehand. The personal interviews took place in the interviewees' offices, and each interview lasted about 60 minutes. The time for telephone interviews ranged from 30 to 50 minutes. Extensive notes were made during interviews and subsequently typed onto a computer file after each interview.

Accordingly, the primary data of this case study is from two groups of interviewees. One is the participants of this action, and the other is the non-participants. As an old Chinese saying goes, "the onlooker sees the game best," the non-participants" perspectives provide more balanced or more comprehensive evidence to this case. The first group includes four fund managers (interviewees "A," "B," "C," and " $D$ ") and one top manager from CMB (interviewee "E"). These fund managers were among the first batch of fund alliance to object the issue proposal. Interviewee " $\mathrm{A}$ " was the organiser of this action and worked at a Beijing-based fund management company, which held the largest amount of tradable shares of CMB. Interviewee " $\mathrm{B}$ " was the first person to express his complaint about the issue proposal to the public and worked at a Shenzhen-based fund management company. Interviewees " $C$ " and " $D$ " were fund managers from a Shanghai-based and Shenzhen-based fund management companies respectively. As key participants of this collective action, they organised/attended their private meetings each time. Interviewee "E" was the member

\footnotetext{
${ }^{54}$ It is reported that the first case in which Chinese financial institutions played a role in corporate issues was the shareholding fight between fund managers and Shandong Shengli Co. in 2000.
} 
of this proposal group in CMB. As the five interviewees were closely involved in this case, they were the most cogent interviewees for this case study, and I believe that they were more well-informed and gave more informative insight than the rest of the participants.

The second group includes two senior managers (interviewees " $F$ " and "G") from two securities companies, two board directors (interviewees " $\mathrm{H}$ " and "I") from other two listed companies, and one government official (interviewee "J") from the China Securities Regulatory Commission (CSRC). Interviewee " $\mathrm{H}$ " worked in a listed company located in the same part of China as CMB and listed on both domestic stock market and the Hong Kong Stock Exchange. Interviewee "I" came from another publicly traded lender. Although interviewees they were the onlookers, they were very concerned about the incident. I collected their perspectives about why the fund managers took this collective action, how they fought with CMB, and why they only achieved a limited amount of success.

Complementary data was obtained from public sources, such as Juchao Information, ${ }^{55}$ the bank's annual reports, papers, and news published on the Internet, magazines, and newspapers. ${ }^{56}$

The CMB case is of great significance in the sense that it not only improves the position of financial institutions on the stock markets and enhances the confidence of minority shareholders, but also initiates the self-examination about the inherent defects of Chinese stock markets. All interviewees considered it as a milestone of Chinese capital market with far-reaching influence.

\subsection{The background of China Merchants Bank}

\subsubsection{The ownership structure}

Founded on $8^{\text {th }}$ April 1987 with its head office in Shenzhen, China Merchants Bank (CMB) is the first shareholding commercial bank wholly owned by corporate legal entities. Since its establishment, the bank has undergone capital enlargement three times, and launched IPO with the issuance of 1.5 billion common shares in March 2002 and was successfully listed in the Shanghai Stock Exchange on $9^{\text {th }}$ April 2002 (Stock Trading Code: 600036 ).

\footnotetext{
${ }^{55}$ Its website is named by the CSRC to disclose the securities information.

${ }^{56}$ Such as "Securities Market Weekly" and "Financial Times."
} 
After about 17 years' development, $\mathrm{CMB}$ has transitioned itself from a regional bank into a national commercial bank with certain scale and influence. The total asset was over 0.5 trillion yuan at the end of $2003 .{ }^{57}$ After the conversion of capital reserve to share capital in May 2004, the Bank's total shares have increased to 6.4 billion, and the total asset is above 600 billion yuan, and is ranked in the top 200 among "the world 1000 banks" by a British financial journal The Banker. In recent years, CMB won rewards and recognition granted by a number of domestic and overseas press organisations, such as 'the Best Domestic Commercial Bank in China,' one of 'the Most Respectable Enterprises in China,' and one of 'the Top Ten Public Companies in China' respectively.

During its development, CMB increased its capital and expanded shareholdings. At the end of 2003, the ownership structure is described in Table 8.1.

\section{Table 8.1 The ownership structure of China Merchants Bank}

\section{$31^{\text {st }}$ December 2003}

This table describes the ownership structure of CMB at the end of 2003. Source: The website of Juchao Information, http:// www.cninfo.com.cn.

\begin{tabular}{|l|r|r|}
\hline Categories of shares & Number of shares & Percentage \\
\hline Non-tradable shares & $4,206,818,044$ & $73.72 \%$ \\
\hline Including: (1) State shares & $2,233,080,744$ & $39.13 \%$ \\
\hline \multicolumn{1}{|c|}{ (2) Legal person shares } & $1,973,737,286$ & $34.59 \%$ \\
\hline Tradable shares & $1,500,000,000$ & $26.28 \%$ \\
\hline Total shares & $5,706,818,030$ & $100 \%$ \\
\hline
\end{tabular}

It appeared that the ownership structure of CMB was very typical among listed Chinese companies. (1) The ownership was highly concentrated. 73.72 per cent of total shares was concentrated on the hands of state (39.13 per cent) and legal person investors ( 34.59 per cent), and remained non-tradable. (2) The percentage of tradable shares was relatively low, which accounted for only 26.28 per cent, less than one third of the total shares. (3) The number of individual shareholders was relatively high. The company had a total of 160,917 shareholders at the end of 2003. These individual investors were segmented, segregated and shareholding ratios were relatively low. In addition, other factors including geography, time-zone, etc., further restricted individual investors' participation in the management and significant-decision-making process of the bank. This concentrated ownership structure,

\footnotetext{
${ }^{57} £ 1=R M B ¥ 15.8$ at the end of 2003 .
} 
with high percentage of non-tradable shares and low tradable shares had enabled the control of the bank to remain within the promoters who were state-owned shareholders or state-controlled shareholders.

\subsubsection{The top ten shareholders}

Table 8.2 describes the information of the top ten shareholders of the bank. It is obvious that corporate entities as shareholders had the dominant position. The first largest shareholder, Steamboat Limited Co. of China Merchant Bureau, held 17.95 per cent of total shares. The second and third largest shareholders held 8.61 per cent and 5.70 per cent respectively. The fractions of shares held by the first largest shareholder, top three, top five shareholders, and top ten shareholders were 17.95 per cent, 32.26 per cent, 37.98 per cent and 47.03 per cent respectively. It appeared that ownership structure was highly concentrated on the top five shareholders, and the first largest shareholder had the most influential power on corporate operation and the performance of its stock price. Accordingly, the control was actually in the hands of a small number of insiders.

\section{Table 8.2 The top ten shareholders of China Merchants Bank}

\section{$31^{\text {st }}$ December 2003}

This table describes the top ten shareholders of CMB at the end of 2003. Source: The website of Juchao Information, http:// www.cninfo.com.cn.

\begin{tabular}{|c|l|l|r|r|}
\hline No. & Name of top shareholders & $\begin{array}{l}\text { Type of } \\
\text { ownership }\end{array}$ & $\begin{array}{l}\text { Number of } \\
\text { shares }\end{array}$ & Per cent \\
\hline 1 & Steamboat Ltd Co. of China Merchant Bureau & legal person & $1,024,651,109$ & $17.95 \%$ \\
\hline 2 & China Ocean Transportation Co. & legal person & $491,344,193$ & $8.61 \%$ \\
\hline 3 & Guangzhou Sea Transportation Co. & legal person & $325,140,920$ & $5.70 \%$ \\
\hline 4 & Youlian Shipyard Co. & foreign & $182,068,000$ & $3.19 \%$ \\
\hline 5 & Shanghai Car Industry Co. & legal person & $144,101,090$ & $2.53 \%$ \\
\hline 6 & China Harbour Construction Co. & legal person & $112,142,056$ & $1.97 \%$ \\
\hline 7 & Qinhuang Island Port Co. & legal person & $101,189,750$ & $1.77 \%$ \\
\hline 8 & Shandong Traffic Development Investment Co. & legal person & $101,189,750$ & $1.77 \%$ \\
\hline 9 & Guangdong Highway Administration & state shares & $101,189,750$ & $1.77 \%$ \\
\hline 10 & China Sea Transportation Co. & legal person & $101,189,750$ & $1.77 \%$ \\
\hline
\end{tabular}

There existed related parties among the top ten shareholders. The first largest shareholder was the parent company of the fourth largest, and the third largest was wholly owned by the tenth largest. There is no such relationship among other top shareholders. In this respect, related party transactions, and insider control problem, such as transferring firm assets from 
state-owned enterprise to non-state-owned enterprise, profit stealing, cannot be avoided among large shareholders.

\subsubsection{The top ten tradable shareholders}

Table 8.3 describes the information about the top ten tradable shareholders of CMB at the end of 2003. They included seven investment funds and three other companies. Among the seven investment funds, China Asset Growth, China Asset Repayment, Xinghe and Xinghua Investment Funds were under the supervision of the same fund management company, i.e., China Asset Management Company, who was the largest tradable shareholder with 1.63 per cent of total shares.

The total fraction of shares held by the top ten tradable shareholders was only 4 per cent, which further implied a very low contestability of control by non-tradable shareholders. The top seven investment funds accounted for 2.75 per cent of total shares, which accounted for 68.76 per cent of the total shares held by the top ten tradable shareholders, therefore, they were the large tradable shareholders, and were expected to protect the interest of minority shareholders.

\section{Table 8.3 The top ten tradable shareholders of China Merchants Bank}

\section{$31^{\text {st }}$ December 2003}

This table describes the top ten tradable shareholders of CMB at the end of 2003. Source: The website of Juchao Information, http:// www.cninfo.com.cn.

\begin{tabular}{|c|l|r|r|}
\hline No. & Name of shareholders & Number of shares & \multicolumn{1}{c|}{ Per cent } \\
\hline 1 & China Grain and Oil Export Co. & $40,500,000$ & $0.71 \%$ \\
\hline 2 & China Asset Growth & $27,000,000$ & $0.47 \%$ \\
\hline 3 & Tongsheng Funds & $26,000,000$ & $0.46 \%$ \\
\hline 4 & China Asset Repayment & $22,890,973$ & $0.40 \%$ \\
\hline 5 & Xinghe Investment Funds & $21,702,974$ & $0.38 \%$ \\
\hline 6 & Xinghua Investment Funds & $21,544,853$ & $0.38 \%$ \\
\hline 7 & Penghua Industry Growth funds & $21,420,321$ & $0.38 \%$ \\
\hline 8 & Xintian International Economic and Technology Co. & $16,238,775$ & $0.28 \%$ \\
\hline 9 & Anshun Investment Funds & $16,000,000$ & $0.28 \%$ \\
\hline 10 & Yunnan Power Co. & $15,000,000$ & $0.26 \%$ \\
\hline \multicolumn{2}{r|}{ Total } & $228,297,896$ & $4.00 \%$ \\
\hline
\end{tabular}




\subsubsection{The corporate governance of China Merchants Bank}

CMB had thirteen inside directors and six independent directors in its board of directors, and none of them is the representative of tradable shareholders. Ten of thirteen inside directors also took senior management positions in its major shareholders. Under the supervision of board of directors, there were a nominating committee, audit and relatedparty-transaction control committee, risk management committee, and remuneration and appraisal committee. The independent directors were the main members in these committees. The six independent directors included one professor, one lawyer, one retired government official, and three general managers from other financial institutions. ${ }^{58}$ All of them were nominated by large shareholders, and none was endorsed by minority shareholders. Each independent director was paid 80,000 yuan per year. It was obvious that the board directors were mainly nominated by main shareholders, and the board highly overlapped management.

There were nine directors in the supervisory board, including three outside directors, two employees' representatives and four inside directors. These four inside directors also held senior management positions in CMB's major shareholders. In 2003, the supervisors met less often ( 5 times) than the board of directors (12 times).

The bank drew up the System for Investor Relation Management in December 2003, and established the investor relations department, which was also the office of the board of directors. The activities of this department included shareholder relations, disclosure and valuation. Various forms of communication were employed by the investor relations department, including announcement, shareholders' meetings, corporate website, poster, telephone queries, media interview and report, analyst meetings, advisement, road show, face-to-face meetings, on-spot investigation, questionnaires, and others. They promised constant contact with investors and quick feedbacks from the board of directors about investors' concerns. In this System for Investor Relation Management and other company regulations, CMB emphasised that the rights of all shareholders would be well protected and the treatment toward all shareholders be fair.

\footnotetext{
${ }^{58}$ It seems they were competent to be independent directors, however, their independence needed to be discussed.
} 


\subsection{The dispute between China Merchants Bank and financial institutions}

\subsubsection{The incident that ignited the dispute}

On $26^{\text {th }}$ August 2003, the board of directors of CMB put forward a controversial issue proposal in its interim report. The issue proposal mainly stated as follows: the board of CMB was planning to issue five-year convertible bonds of no more than 10 billion yuan; the interest rate of the bond in the first year was 1 per cent, increasing progressively at the rate of 0.375 per cent from the second year, and reach 2.5 per cent in the final year.

The announcement of the issue proposal strongly surprised and hurt the bank's financial institutions and other tradable shareholders, because these tradable shareholders knew nothing about it beforehand. Accordingly, it produced instant results- the share price decreased dramatically by 13 per cent within the twenty trading days since the announcement, and CMB suffered the huge loss of 10 billion yuan. In this respect, financial institutions began their dispute against the issue proposal with collective action, attempting to protect the interests of their beneficial owners.

Three main conflicts arose from the issue proposal between the fund managers and CMB:

- The scale of new issue. The proposed bond issue with 10 billion yuan was the largest scale to raise additional funds in the A-share market. CMB set a precedent of malignant refunding to raise such huge amount of re-financing only one year after its first funding in 2002. It was estimated that only 3.7 billion yuan of funds was needed for CMB to reach 8 per cent of capital adequacy ratio, which was required by Chinese central bank. If the ratio reaches 9 per cent, the funds would increase to 7.6 billion. However, the spare funds over 7.0 billion would not produce profit before 2005, thus would do harm to tradable shareholders.

- The way of new issue. The available options for commercial banks to re-financing normally include an issue of subordinate bonds, script issues, rights issues, and an issue of convertible bonds. To CMB, it was the best way to issue convertible bonds because of its lowest cost. However, to tradable shareholders, script issue would be the best way, while issuing convertible bonds would be the worst. Both script issue and right issue can 
replenish core capital of commercial banks, while convertible bonds only replenish subordinate capital at most. According to prevailing regulations that subordinate capital cannot exceed core capital, no more than 6 billion convertible bonds can replenish CMB's subordinate capital. Therefore, it was not the best way to replenish capital. Furthermore, if these bonds cannot be converted into shares by 2005, the normal operation will be disturbed and it will harm the bank's stable development.

- The timing of new issue. At that time, it was not a good time for the bank to raise such huge funds, as the central bank limited the growth of money supply and the stock market was in a depressed state. However, the bank attempted to re-finance under such stagnant context, suggesting that $\mathrm{CMB}$ totally ignored the interest of tradable shareholders and its own share price.

According to all interviewees from fund management companies, the sale of convertible bonds would benefit the bank, the underwriter, and new investors at the expense of current tradable shareholders. CMB could get a capital premium from the increase of its assets, which also benefit the non-tradable shareholders; the underwriter, China International Capital Corporation Limited (CICC), could collect more than 0.1 billion yuan underwriting fee; and the income source of new investors comes from stable interest and conversion premium on bonds. On the other hand, the creation of new shares would lower earnings per share and cause the price of the publicly traded stock to fall. Therefore, the current tradable shares would be greatly diluted and minority shareholders would be greatly expropriated.

\subsubsection{The process of the dispute}

\subsubsection{The first round}

In early September 2003, interviewee "B" expressed his strong dissatisfaction with this issue proposal to the public. ${ }^{59}$ He complained that numerous funds had suffered great losses because of the sharp drop of the share price after the issue announcement. According to him, the most unreasonable part of the issue proposal was that only 6 per cent of circulation would be sold to tradable shareholders, such that tradable shareholders could not fully enjoy the price gaps between the primary and secondary stock markets.

\footnotetext{
${ }^{59}$ Securities Market Weekly, $10^{\text {th }}$ September 2003.
} 
The dispute began at CMB's half-year meeting on $12^{\text {th }}$ September 2003. Seven fund managers respectively from China Asset Management, Changsheng, Dacheng, Southern Fund Management, E Fund Management, Penghua and Zhongrong Fund Management ${ }^{60}$ arrived, more than one hour earlier than the scheduled meeting time.

Just one day before this meeting, they had already held a private meeting and reached an agreement about what positions they should take and what proposals they should put forward.

After arriving, they exchanged their ideas again, and maintained the same opinion as was discussed in their private meeting. Each fund manager expressed his/her opposition in the book of "Shareholders' Opinions," which was sealed with his/her own company's stamp.

In their books, they stated, "As the shareholders of CMB, we would like to make long-term investment, as we believe that $\mathrm{CMB}$ would have a bright future and we trust the top management. Unfortunately, the current issue proposal greatly disappoints us and we resolutely oppose the bond issue."

At the same time, they put forward three alternative proposals: (1) scaling the bonds issue down to less than 5,000 million; (2) issuing subordinate bonds; and (3) fixing the re-issue only to tradable shareholders. These alternatives not only took the interest of legal person investors into account, but also highlighted the rights of minority shareholders.

In addition, individual investors attended the mid-term meeting eagerly. Their representative vehemently condemned this issue proposal and expressed their strong support to the collective action of fund managers. He pointed out that the corporate management should have discussed with fund managers beforehand, and balanced and respected the interest of all shareholders. His speech aroused sympathy from fund managers.

Facing sharp criticism from fund manages and individual investors, the bank finished the meeting earlier than planned. However, the corporate management did not give any response at the meeting, nor did they provide any assessment of the alternatives. They just

\footnotetext{
${ }^{60}$ This Fund Management Company was renamed UBS SDIC on $8^{\text {th }}$ June 2005.
} 
indicated that they would balance the benefit of tradable shareholders and discuss with the representatives of fund management companies after the meeting.

It seemed that the fund managers won the first round, but "actually, we are very weak," interviewee "A" said with great caution, "We know clearly that we could not have any influence on this proposal. But we hoped that it would be the starting point to push controlling shareholders to consider the voice from financial institutions and individual investors."

\subsubsection{The second round}

From $22^{\text {nd }}$ to $29^{\text {th }}$ September 2003, the corporate management paid return visits to its opponents in Shanghai, Shenzhen, and Beijing respectively, aiming to persuade them to accept its bond issue. Before the return visits, these fund managers had another private negotiation, discussing how to deal with the visits. They prepared what they should exchange with $\mathrm{CMB}$, and what feedback they should give. In this round, they knew more and more clearly about their fiduciary responsibility and became the representatives of tradable shareholders.

However, the communications between fund managers and the bank were very superficial. Interviewee " $B$ " was very unhappy with that visit for two reasons. First, instead of the viceCFO as named in the fax, the visitors were the secretary to the board of directors (equivalent to Company Secretary in the UK) and an issue proposal manager, who did not have any decision-making power. However, $\mathrm{CMB}$ did not give any notice about the change beforehand. Second, the visitors very briefly introduced the issue proposal and expressed that they would think over the feedback from fund managers. It appeared that there was no substantial exchange during the return visit.

In contrast, interviewee " $D$ " gave a positive attitude toward that visit as it provided at least a chance to pass their complaints to the top management of the bank.

$\mathrm{CMB}$ intended to gain understanding and support from fund managers, but the bank did not get the anticipated results. Interviewee " $\mathrm{C}$ " concluded: 
"The bank could not get paid easily for what they had done, because they lacked sincerity. Although all the tradable shareholders cannot occupy a dominant position in the interim shareholders' meeting, we would like to try our best to dispute for the rights of tradable shareholders."

Interviewee " $D$ " thought it unnecessary for the bank's management to visit the opponents from house to house, as they held the same opinions. According to him, what CMB should do was to consider the proposals seriously and give them feedback. These opponents suspected that the visits were just a gesture to the CSRC, the public and the media.

During the second round, some other financial institutions took part in the fund alliance. After two rounds, the fund alliance became much stronger, consisting of 47 funds and one securities company, more than 5.78 per cent of total shares. The dispute seemed to become fierce.

Interviewee "F" said that the case was not a pure and simple incident, but a mirror that reflected the inherent defects of Chinese stock market, as it was a dispute between majority (non-tradable) and minority (tradable) shareholders.

\subsubsection{The third round}

On $14^{\text {th }}$ October 2003 , which was one day before the interim shareholders' meeting, fund managers from more than 10 fund management companies gathered in Shenzhen to discuss and prepare countermeasures. Their discussion focused on the validity and the voting procedure of the issue proposal. On the following day, fund managers took four measures at the interim shareholders' meeting. First, they vetoed the issue proposal. Second, they questioned the validity of the bond issue. Third, they pointed out that the issue proposal violated the principle of "fair treatment to all shareholders," which was emphasised in the corporate constitution of the bank. Finally, the fund alliance demanded separate voting between non-tradable and tradable shareholders at the meeting.

However, just as the fund managers anticipated, $\mathrm{CMB}$ ultimately won the approval for the bond issue, spurning minority investors' complaints. To mollify shareholders, the president of $\mathrm{CMB}$ expressed that the company would look into ways to modify the issue proposal 
and balance the expressed concerns from tradable shareholders. The proposed revision would reflect such aspects as following:

- About subordinate bonds. CMB would still make the issue of convertible bonds the first choice, because there were no relevant regulations about subordinate bonds at that time. If the regulations were issued during the preparation for convertible bond issue, they would apply to issue subordinate bonds partly or wholly.

- About the scale of bonds. CMB would respect the suggestion of individual investors and determine an appropriate scale of bonds within "no more than 10 billion."

- About the ratio issued to the current shareholders. If the current shareholders were willing to subscribe for convertible bonds, the company would request the board of director to change the current article "subscribing 4 yuan per 10 shares" into "the current shareholders have the priority to subscribe for all the bonds, and the market then subscribe for the remainder."

- About the conversion premium on bonds. The company would increase the conversion premium on the bonds to 10 per cent or more, which was twice as high as what fund managers expected.

- About adjusting the price downward. The current clauses prescribed that the board of director had the right to adjust the conversion price on bonds downward within the range of 20 per cent. Since some financial institutions thought the range unreasonable, the company would request the board to change the range to be $25-30$ per cent.

Although the five aspects were the tentative ideas, it appeared that the company began to take the interest of tradable shareholders into account.

After the interim shareholders' meeting, the fund managers and the securities company held a press conference, issuing a joint statement. The statement indicated that (1) it was a great pity that the issue proposal was approved, suggesting that the CMB spurned complaints from the shareholders with at least 0.33 billion tradable shares; (2) they would 
go on fighting for their own rights by means of law; and (3) they asked the regulators to check listed companies from raising additional funds.

The approval of the issue proposal signified a failure of the fund alliance by then. It was obvious the time for the securities regulators to take the action. Interviewee "E" said that since the bank had a different way from the fund alliance to understand the current regulations, whether the bond issue was legal or not depended on the CSRC. That is to say, if the CSRC ultimately approved the proposal, it meant that the proposal was legal.

\subsubsection{Follow-up}

From $19^{\text {th }}$ to $27^{\text {th }}$ November 2003, the president of CMB visited opponents in Shanghai, Beijing and Shenzhen respectively again. It was the second return visits of the bank, but this time the president himself was the visitor. It appeared that the voice from financial institutions, represented by investment funds, was being seriously valued. However, the fund managers still insisted on their opinions that $\mathrm{CMB}$ should issue the subordinate bonds instead.

"What we opposed is not the re-funding itself, but the way of re-funding, as the way that $\mathrm{CMB}$ chose would bring the greatest harm to tradable shareholders." Interviewee " $\mathrm{A}$ " explained, "CMB should not ignore the interest of minority shareholders, and consideration should be given to both the amount of funds and the way to get the funds."

Interviewee "B" was indignant at the current segmented share structure. "Indeed we knew the result of the dispute in advance. Under the current segmented share structure, nontradable shareholders can make decisions unilaterally, spurning complaints of tradable shareholders." He said, "And the final victims are definitely tradable shareholders. The CMB case is just one typical example."

"We have nothing to say, as we had already said too much," Interviewee " $D$ " responded to the president's visit, "We just wait and see its development."

Fortunately, the stalemate took a turn for the better when the China Banking Regulatory Commission (CBRC) issued a notice allowing commercial banks to issue the subordinate 
bonds, which can be reckoned into their subordinate capital. Accordingly, in February 2004, $\mathrm{CMB}$ announced its final issue proposal: the bond issue was scaled down to 6.5 billion Renminbi with 3.5 billion subordinate bonds. In addition to scaling down the amount of convertible bonds, the company also made some eclectic revision on some clauses. For example, the bank increased the puttable price from 107 per cent of its original price to 108.5 per cent, and tradable shareholders have the rights to subscribe for convertible bonds twice.

Although the final proposal did not fully satisfy tradable shareholders, the company really made certain concessions, and fund managers achieved a limited amount of success, suggesting that the company took the rights of minority shareholders into consideration.

This incident has profound significance and far-reaching influence. On the one hand, it improves the position of fund managers on the stock market, and the rights of tradable shareholders are taken into account. On the other hand, the incident initiated the selfexamination about the inherent defects of Chinese stock markets.

\subsection{Discussion}

\subsubsection{The factors that affected the outcome of the dispute}

\subsubsection{The ineffective state ownership}

China is a transition economy where the interest of the state is supreme. In state-owned firms, the owner-manager relationship is broken into to two sets of agency relationships. The state represents all of the people to manage all of the assets (owners-to-politicians relationship); and the state, represented by politicians, engages the managers to perform the service (politician-to-managers relationship). As discussed in Chapter 5, such agency relationships effectively reduce the incentives for monitoring managers' behaviour (Cuervo and Villalonga, 2000). The state lacks a clear, accountable representative to enforce its will (Qian, 1996; Steinfeld, 1998), and its representatives, the politicians, have neither incentive nor capability (e.g., due to the lack of information and/or entrepreneurial expertise) to effectively monitor the operation of SOEs under their control. Therefore, the state is the majority shareholder, but not exercising its ownership rights effectively. Instead, the inside managers hold the control of the company. Corporate managers in China have relatively 
wide discretion in running firms, yet there are few mechanisms to ensure that they are acting in the firm's or the state's best interest (Mar and Young, 2001).

CMB is a typical listed company with concentrated ownership structure; 73.72 per cent of total shares remained non-tradable, while 26.28 per cent floated on the stock markets. Furthermore, the top three shareholders accounted for 32.26 per cent of total shares, and four out of ten top shareholders were related parties. Accordingly, the control was concentrated in the hands of the large shareholders, and the board of directors of CMB, accountable only to the large shareholders, had the absolute power to make major strategic decisions. Thus, the governance and the purpose of the firm are totally determined by the controlling shareholders and top managers, who take little consideration to the public.

\subsubsection{The expropriation of minority shareholders}

As discussed earlier, minority shareholder rights are poorly protected in China. The high ownership concentration of listed companies raises the risk of expropriation of minority rights by majority shareholders (Claessens and Fan, 2002). Moreover, the inherent defects of Chinese stock markets naturally reduce the accountability and investment risk exposure of controlling shareholders, exacerbating the agency problem and creating an environment ripe for potential expropriation of minority interests (La Porta et al., 1999a). Interviewee " $A$ " pointed out that the segmented share structure is the main cause of many problems.

"The nature of this incident is the agency problem caused by the segmented share structure," Interviewee " $\mathrm{A}$ " asserted, "It is an expropriation of minority shareholder by majority shareholders and controlling shareholders. Because of overwhelming odds, it is inevitable that minority rights were expropriated when majority shareholders take action to benefit themselves."

It is really a sorrow of Chinese public investors, as their rights can be randomly exploited by the majority shareholders. Interviewee "G" explained that it was mainly the lack of protection of minority rights in China that allowed majority shareholders to expropriate minority shareholders, and that it was a common practice that the fund alliance experienced in the CMB case, and the success of financial institutions in the case of COSCO Shipping 
Co. was just an "outlier.",61

Interviewee "J" showed his sympathy to Chinese public investors, and said with deep feeling, "Chinese individual investors have made great contribution to the development of the stock markets. However, their rights are not always well respected and protected, as there are currently limited laws and regulations to protect their rights. It is the time that we pay attention to their rights."

However, Interviewee "E" denied that the issue proposal exploited the rights of minority shareholders. In his point of view, the creation of new shares diluted the current tradable shares, but public investors could benefit from the long and stable development of the company, which would be made possible by the increased assets through the bond issue.

\subsubsection{The size of institutional shareholdings}

Restricted by the short history, Chinese financial institutions account for a very small percentage of both market capitalisation and number of shares. Statistical data ${ }^{62}$ indicate that in 2001, 2002, and 2003, the average institutional shareholdings of investment funds in the top ten shareholders represented 1.74, 2.37, and 2.13 per cent of total shares respectively. In this case, the top seven funds held only 2.75 per cent of total shares of $\mathrm{CMB}$ at the end of 2003. According to the principal of "one share-one vote," the fund managers had limited voting rights to express their concerns in shareholders' meetings. Interviewee "F" said:

"Minority shareholders, including institutional owners and individual investors, may directly monitor the firm when they hold significant equity stakes. However, because of the small percentage of institutional shareholdings and the lack of relevant discipline to restrict listed companies to raise additional fund, financial institutions normally cannot influence firm strategies via their voting rights. Even if they attempt to monitor, they are ineffective in challenging the usually powerful controlling owners."

\footnotetext{
${ }^{61}$ In 2003, Guoyuan Securities Company successfully vetoed the financing proposal of COSCO Shipping Co., which attempted to purchase the asset from its related parties.

${ }^{62}$ The Sinofin database.
} 


\subsubsection{The effectiveness of other corporate governance mechanisms}

Some researchers have been concerned with the interaction among corporate governance mechanisms. Hermalin and Weisbach (1991) consider the interaction between insider ownership and board composition in a simultaneous equation framework. Jensen et al. (1992) examine empirically the simultaneous determination of insider ownership, debt policy, and dividend policy. Moyer et al. (1992) consider substitutability among board composition, insider ownership, institutional shareholdings, analyst following, debt policy, and dividend policy. Agrawal and Knoeber (1996) find evidence of interdependence among insider ownership, independent directors, debt policy, the managerial labour market, and the market for corporate control.

Since corporate governance mechanisms are interacted, the role of financial institutions depends on the interaction with other corporate governance mechanisms and the effectiveness of these mechanisms. The effective control mechanisms might facilitate the role of financial institutions in corporate governance. However, due to the fact that the ownership is highly concentrated and more than two-thirds of the shares remain nontradable, the executive directors and manages are highly overlapped and represent large shareholders, independent directors and supervisors are always captured by the company. The ineffective boards of directors, independent directors, and supervisory boards do little to alleviate agency problems between minority shareholders (including both institutional owners and individual investors) and controlling shareholder (Chen and Wang, 2004).

\subsubsection{The board of directors}

The role of a board of directors, which is discussed in Chapter 3, is to actively monitor management to prevent expropriation of shareholder interests, particularly of the minority shareholders.

However, in China politicians and state-controlling owners occupy most board seats in listed Chinese companies. Chen et al. (2002) present data on the boards of directors of 621 companies that went public from 1993 to 2000 in China. They report that almost 50 per cent of the directors are appointed by the state controlling owners, and another 30 per cent are affiliated with various layers of governmental agencies. In CMB, there were no representatives of minority shareholders on the board, and most of inside directors had high 
positions in their main shareholders. It was obvious that the board directors were mainly nominated by main shareholders, and the board highly overlapped management. This governance structure enabled controlling shareholders to enter into large numbers of related party transactions with the listed company, by manipulating the shareholders general meetings and board, at the expense of the company and minority shareholders, including financial institutions. No matter how strongly the minority shareholders said "No," the CMB's board of directors dared say "Yes." It is not the case in the US. The boards of American public corporations dare not say "No," when their shareholders say "Yes" (Brownstein and Kirman, 2004).

Interviewee "C" complained, "If the CMB's board took serious consideration to our complaints, we may restrict the expropriation and protect the minority rights."

In addition, it is argued that the board of directors should operate independently for the benefit of its company and should not succumb to improper pressure and direction from other affiliated companies (Jang and Kim, 2002). Interviewee " $A$ " believed that the CMB's board followed the decisions of the board of the China Merchants Group. He explained:

"Mr Qin, the chairman of the bank's board, is also the legal representative of its largest shareholder, which was a wholly-owned subsidiary company of the China Merchants Group, and concurrently the chairman of the Group. The fact that one person served on three highest positions of three affiliated companies explicitly implies that the board is just accountable to the key shareholders, and such major strategic decision as convertible bond issue seemed to be agreed upon beforehand among the key shareholders, and outside the formal shareholders' meeting or boardroom."

\subsubsection{The independent directors}

As discussed in Chapter 3, independent directors may be able to do a better job in monitoring and controlling management to combat agency problems due to their presumed independence relative to inside directors. According to the above mentioned the Guidelines (CSRC, 2001), Chinese independent directors are explicitly instructed to protect the overall interest of the company, be especially concerned with protecting the interests of minority shareholders from being infringed. However, in this case, six independent directors failed 
to fulfil their duty in preventing expropriation of interests of minority shareholders.

Before the mid-term meeting, CMB held a board meeting in August 2003, and approved the issue proposal. All independent directors attended this meeting, but their opinions about the proposal were not disclosed. Furthermore, during the dispute, none of the independent directors supported the collective action and said "no" to the company board, together with tradable shareholders. According to the above mentioned Guideline (CSRC, 2001) issued by the CSRC, the independent directors shall express the independent opinions on events that they consider to be detrimental to the interests of minority shareholders, and their opinions should be disclosed if they say "No." Accordingly, their behaviour implied that they supported bond issue proposal by neglecting the interest of minority shareholders, including financial institutions.

"Since independent directors are nominated by large shareholders and none of them is endorsed by minority shareholders, how can they create difficulties to large shareholder?" Interviewee "B" said with disappointment, "Not every independent director is likely to be truly independent, given the presence of affiliated independent directors. Even in the case of non-affiliated independent directors, CEOs may still employ a number of tactics to neutralise the power of these directors."

Indeed, it is really a problem that CEOs neutralise the power of independent directors to protect their own power. For example, CEOs appoint independent directors who are demographically similar, thus they can get more sympathy (Westphal and Zajac, 1995). CEOs may also appoint directors with experience on other passive boards and exclude individuals with experience on more active boards (Zajac and Westphal, 1996). Alternatively, CEOs may appoint individuals who are from strategically irrelevant backgrounds that may not provide an appropriate knowledge base to effectively participate in strategic decision making and challenge CEOs' power (Carpenter and Westphal, 2001).

Additionally, it can be costly for independent directors to challenge the CEO to whom their careers are tied (Weisbach, 1988). Under Chinese cultural circumstances where personal relationship is treasured, to maintain friendly relationship becomes a prerequisite for most independent directors when they perform their duties. Furthermore, each independent director was paid 80,000 yuan per year by $\mathrm{CMB}$ each year. This was not a small amount of 
money. "Because of the dominance of state and legal person shares, most independent directors subject themselves to the influence of the company's major shareholders, actual controller, or other entities or persons who are interested parties of the listed companies." Interviewee " $\mathrm{D}$ " argued, "It is a very common phenomenon among listed Chinese companies that the company pays them the money to buy their agreement, CMB is not exception."

\subsubsection{The supervisory board}

According to the above mentioned the Code (CSRC, 2002), supervisory board is set up to monitor the board directors and senior executives, and is accountable to all shareholders.

The CMB's annual report in 2003 did not publish any different opinions on the issue proposal from those of the board of directors, which indicated that they had no objection to the issue proposal.

In China, "strong management and weak supervisory board" becomes the reality. Often, supervisory board directors and non-executive directors are "captured," they become part of group of insiders and identify with their interest (Lin, 2001).

"It is a fact that the supervisory boards in China rarely contest the decision made by boards of directors and company executives." Interviewee "F" said, "In the case of CMB, how could it be possible that they objected that issue proposal that benefited themselves?"

\subsubsection{The investor relations}

Since in China the board directors were representatives of majority shareholders and the independent directors and supervisors were mostly captured, it is inevitable that they did not pay attention to the concern of financial institutions. The System for Investor Relations Management was only a decoration.

After the announcement of the bond issue proposal, the bank just took some superficial measures, and ultimately approved the issue proposal, spurning strong objection of their tradable shareholders. 
"It is a very unwise move for CMB to offend its financial institutions." Interviewee " $\mathrm{H}$ " said, "In our company, we have already realised the importance of financial institutions in the stock markets and have established a good relationship with domestic and international financial institutions. After being listed on the Hong Kong Stock Exchange, our company is also monitored by the international investors as well, who are active and professional monitors. Therefore it is an important strategic corporate activity for each listed companies to establish good investor relation, no matter where it is listed."

In contrast, interviewee " $E$ " repeated that his company had established a good investor relationship. He explained:

"It was a misunderstanding that my company should have discussed the issue proposal before the announcement. According to the Securities Law and relevant regulations, material events cannot be disclosed before they are approved by the board of directors. Consequently, it was unfair to treat my company as a negative sample as the procedure to disclose this issue proposal totally met the requirement of the CSRC."

However, no matter how interviewee "E" explained the company's behaviour, CMB paid the deserved price.

"It is a great pity that the incident changed the company from a favourite to a foundling of the stock market, as it was once a promising blue-chip company." Interviewee "I" said, "And ironically, after that, when we talk to our financial institutions, we always begin with the remark 'we are not CMB...",

\subsubsection{The nascent shareholder activism in China}

In general, most Chinese financial institutions are passive shareholders, and only limited active investment funds play a role in corporate governance in their portfolio companies. Interviewee "F" said that limited number of institutional shareholders expressed their dissatisfaction at shareholders' meetings, and most institutional shareholders rarely questioned any decisions, rarely attended shareholders' meetings, never sought any injunctions against the board, never requested any inspections of the board's minutes, nor 
were any legal actions ever filed against the management for any negligence or malfeasance.

Interviewee " $G$ " noted that the fund managers in this case voiced their opinions mainly because they had suffered a huge loss, and that they just fought for their own benefits first, and then became the representatives of tradable shareholders unconsciously. What he said supported the argument that Chinese financial institutions intervene in the firm strategies and other corporate affairs only in extreme cases (Mar and Young, 2001). If they had kept constant contact with their portfolio companies like their western counterparts (for example, see Interview, 2000), fund manager in this case could have learnt the issue proposal beforehand, and could not have suffered such a huge loss.

However, this case marked that the stage of Chinese shareholder activism was coming. Financial institutions seemed to have the incentive, resources, and skills to monitor corporate management.

\subsubsection{The incentives for the collective action}

Financial institutions are delegated monitors for their beneficiaries and are expected to closely monitor their holdings and take action to protect investments against erosion in value. Accordingly, to restrict the expropriation of minority shareholders by majority shareholders became an important incentive of this collective action.

"Current tradable shares would be greatly diluted by the creation of new shares, and the rights of minority shareholders would be greatly expropriated." Interviewee "A" explained, "Since we have the same benefit with tradable shareholders, we should try our best to safeguard our investment."

Meanwhile, some authors argue that a financial institution compares the expected costs of a course of action with the expected benefits to decide whether and when to become active (e.g., Stiglitz, 1985; Admati et al., 1994; Clearfield, 2005).

Since CMB announced the issue proposal, its share price had decreased dramatically and the funds had suffered a loss of 400 million yuan in one month. The four fund managers 
explained that they compared the expected costs of collective action and the expected benefits. The costs of collective action mainly included the low cost of holding informal discussions within each other and with the management of CMB. However, the benefits might be infinite and long-lasting. It depended partly on the probability of success. Furthermore, the action could help them establish a good reputation on the stock market. The benefit/cost ratio was likely to be more favourable for collective action than for acquiescence. Therefore, they did so without any hesitation.

However, interviewee " $E$ " denied the relationship between huge losses and the announcement of the issue proposal. In other words, if CMB did not announce the issue proposal, it was still very possible that the share price would fluctuate. He attributed the drop of the bank's share price to systemic risks of stock market and banking industry, such as the increased reserves ratio, decreased credit, and the IPO of China Minsheng Bank.

In addition, fund managers attempted to warn such an illegal action through their collective action. "CMB's issue proposal was followed by many other listed companies who also submitted their applications to the CSRC for convertible bonds during that time," Interviewee "J" said, "As nearly one hundred companies met the requirements of the CSRC, the fund managers might have considered to dispute with CMB as a warning to other companies."

Interviewee "I" confirmed such consideration of fund managers. He said, "This incident did sound a warning against malignant re-funding in the stock market. Other publicly traded lender and my bank draw a lesson from $\mathrm{CMB}$, and learn how to make full communications with our financial institutions before raising additional funds."

\subsubsection{The methods of institutional intervention}

Given the inherent nature of the agency problem, the shareholders must have the means and incentive to oversee managerial decisions (Jang and Kim, 2002).

Interviewee " $\mathrm{A}$ " concluded that the main methods for Chinese financial institutions to intervene corporate issues included communications with corporate management, voting in 
general shareholders' meetings and making public comments. In this case, the fund alliance employed several methods to intervene in the corporate strategy.

\section{(1) Collective action}

Collective action of funds can demonstrate stronger power compared with an individual fund. In August 2003, 53 funds held 0.37 billion shares of the company, constituting 27 per cent of the total tradable shares. Each investment fund held very tiny percentage of total shares. For example, China Asset held 63 million, Dacheng 30 million, Changsheng 46 million, Penghua 42 million, and E Funds 32 million. If another investment funds, Fuguo, who also expressed the same opinions although absent at the meeting, was incorporated, the total amount held by investment funds would reach 0.26 billion, 4.6 per cent of the total shares of CMB. As an old Chinese saying goes, "Unity is strength," only did these funds take collective action, could they have more chances to contend with the majority shareholders.

In contrast, non-tradable shareholders were relatively too strong, holding 73.24 per cent of total shares. Interviewee "A" explained the two "trump cards" that supported the bank's uncompromising stand: one was the eight per cent of capital adequacy ratio required by the central bank; the other was the support from all non-tradable shareholders. He believed that collective action by large financial institutions through informal groups was an effective tool of corporate governance. Interviewee " $\mathrm{C}$ " echoed:

"Since we are small in size compared with the state/legal person ownership, only when we united, can we have stronger power to voice our concern. As we had the same interests, it is very easy to reach the agreement about the collective action among us."

\section{(2) Voting with hands}

At the meeting on $12^{\text {th }}$ September 2003, the fund managers criticised the issue proposal for ignoring the rights of tradable shareholders. Meanwhile, they put forward three alternative proposals, which highlighted the interest of minority shareholders. Under the pressure from the corporate management, fund managers insisted on their objection to the issue proposals throughout the incident. 
Significantly, it was the first time in history that 48 financial institutions united and had one voice to vote against the corporate strategy of their portfolio companies. However, interviewee " $A$ " expressed his pity that they voted just with their 'hands', not with their 'feet' at the same time.

Interviewee " $\mathrm{D}$ " explained, "Actually, CMB is a promising blue-chip company, and its promising growth and prospect are greatly approved among investment funds. Although the issue proposal disappointed and hurt us, we still hold its shares, as China has too few promising blue-chip companies. We can do nothing if we sell off all its shares." In his mind, it is understandable that good companies can also do evil deeds under the segmented share structure, and it is the inherent defects of the stock market that allow non-tradable shareholders take advantages of the opportunity to exploit tradable shareholders.

Interviewee " $B$ " explained another reason why they just voted with hands, that is, fund managers worried about the past mistake being repeated if they voted with both hands and feet. He compared this case with that of ZTE corporation. ${ }^{63}$ The two cases had some similarities: CMB and ZTE are both Shenzhen-based listed companies with good reputation; both held the shareholders' meetings in Shenzhen; both proposals were about raising funds; fund managers were the representatives in both cases; and the results were also the same, both proposals were ultimately approved by the shareholders' meetings respectively. However, the difference did exist; investment funds voted with both hands and feet in the ZTE case, i.e., they sold off all the shares of ZTE, while in CMB case, fund managers voted only with hands. Interviewee " $B$ " was still angry when he recalled the case, "However, the ZTE's board of directors did not carry out its proposal and made a big fun with us. We had to choose our portfolio companies again, which cost us time and money." Taking this lesson, fund alliance dared not to vote against the proposal with hands as well as feet in the CMB case.

Voting with feet is not the best choice for investment funds. An attempt to offload large block of shares in a single firm adversely affects its stock price. As such, the selling institution will be faced with an even greater loss in the value of their holdings. Nontradable shareholders are immune to market fluctuations, as their concern was the value of net assets, not share price. In contrast, small tradable shareholders have to shoulder all the

\footnotetext{
${ }^{63}$ This case is discussed briefly later.
} 
market risks. Take this case for example. If the share price fell by 1 yuan, tradable market capitalisation would 'vaporise' by 1.5 billion yuan, and total market capitalisation would 'vaporise' by 5.7 billion. However, it is the tradable shareholders, rather than the nontradable shareholders, who would suffer from the loss. Interviewee " $C$ " said that it was not reasonable to sell off this company's shares as the share price was very low at that time.

\section{(3) Bad publicity}

Financial institutions took full advantage of media to make adverse public comments in this case. Interviewee "I" argued that this action damaged the bank in terms of its share price and its overall business reputation. After the shareholders' meeting, fund alliance did not give up. Rather, they held a press conference, issuing their joint statement. Interviewee " $\mathrm{B}$ " explained:

"The sun is the best disinfectant, and the media bring the public into full play in monitoring. It is an effective disciplining mechanism in corporate governance to use the media as media attention can affect managers' and board members' reputations in the eyes of shareholders, as well as in the eyes of the society at large." The evidence from the counterparts in developed economies supports his argument. ${ }^{64}$

Interviewee "F" agreed that the media do play a role in shaping the public image of corporate managers and directors, and in so doing they pressure them to abide by social norms. This pressure can lead to shareholders' value maximisation.

In this case, the public and the media gave great support for the fund alliance. Numerous newspapers, such as China Daily, China Securities Journal, followed the track of the incident, and provided the detailed and objective reports.

Interviewee " $\mathrm{J}$ " was surprised at the strong support from the media, and he admitted that the CSRC was indeed caught in the dilemma after the company's interim shareholders' meeting in October, as it was the judger to decide who the winner was, CMB or the fund alliance.

\footnotetext{
${ }^{64}$ Dyck and Zingales (2002) provide both anecdotal and systematic evidence about the corporate governance role of the media.
} 
On the one hand, if the CSRC approved the previous issue proposal, it would disappoint the public. More seriously, it would impair not only the interest of tradable shareholder, but also the healthy development of the stock market at large, as there would be more listed companies following the behaviour of CMB because of the sample effect. On the other hand, the CSRC had no reason to deny the proposal, as all procedure met its requirement. Denial of this issue proposal meant that the CSRC denied its own work.

Fortunately, the issuance of the regulation about the subordinate bonds solved this dilemma. In this sense, media attention could drive politicians to introduce law reforms or enforce corporate laws in the belief that inaction would shame them in the eyes of the public opinion both at home and abroad (Dyck and Zingales, 2002).

\section{(4) Asking for political support}

On the second day of the interim meeting, these fund managers reported the issue proposal to the President of the CSRC. The president expressed his support for the collective action of the fund alliance to protect the interest of minority shareholders.

Interviewee " $F$ " and " $G$ " noted that it was a Chinese approach to ask for political support in corporate issue. Interviewee " $\mathrm{B}$ " said:

"We knew clearly that it was impossible for the CSRC to deny the issue proposal, otherwise, he would slap on his own face. But we hope that our interest would be taken into account when it makes decision."

Interviewee "A" analysed, "It is a well known fact that financial institutions are a key element in the development of Chinese capital market that rewards companies with good corporate governance practices. Chinese government will not dampen the enthusiasm of financial institutions since every effort is being made to develop a healthy stock market." According to his view, it was anticipated that $\mathrm{CMB}$ made some concessions in the bond issue after the issuance of relevant regulation on subordinate bonds. He even doubted that this regulation was issued just to solve the CSRC's dilemma, and the final issue proposal was the result of political interference. 


\subsubsection{The prospect of shareholder activism in China}

In this case, financial institutions have demonstrated themselves as the monitors of corporate management, representing the rights of minority shareholders. They have the incentive, the resources, and skills to intervene in corporate issues. All interviewees from financial institutions explained some conditions favourable to prospect of shareholder activism.

\subsubsection{The precedent development of financial institutions}

Financial institutions grow rapidly from $2000^{65}$ under the support of a series of policies. The investment funds have achieved unprecedented development in particular. It is reported that the net asset of investment funds accounted for nearly 25 per cent of total negotiable market capitalisation in the two stock exchanges, and the assets invested on shares had 13 per cent of that market size by the end of 2004 (Securities Daily, $4^{\text {th }}$ January, 2005). These institutions are gradually becoming the pillar of the securities market, and are playing an active role in corporate governance.

In practice, investment funds are more powerful because the concentration of institutional shareholdings on some blue-chip companies increases ( $\mathrm{Ji}, 2005)$. For example, at the end of July 2004, three fund management companies took on all top ten tradable shareholders of Top Energy Co. (Code: 600780), among them, E Fund Management Company held 8.6 per cent of total shares (Shanghai Securities Journal, 20 ${ }^{\text {th }}$ July 2004). Therefore, when they are not satisfied with portfolio companies, they can penalise them with their feet. For example, on $19^{\text {th }}$ July 2002, the ZTE (Code: 000063 ) announced a proposal to issue H-share on Hong Kong Stock Exchange, but it was strongly opposed by fund managers. After the company stick to the proposal, the fund managers retaliated by selling off all their shares. By the end of 2002, ZTE's share price dropped by 45 per cent, and ZTE disappeared from the name list of fund managers. At the beginning of 2003, the board of directors cancelled the proposal on the pretext of slack situation of Hong Kong stock market. Only by then did fund managers invest in that company again, so did its share price begin to rise.

\footnotetext{
${ }^{65}$ In 2000 , the government put forward an important strategic decision to devote main efforts to developing financial institutions, and investment funds are the priority.
} 


\subsubsection{The weak corporate governance}

During the past years, China is accelerating its development of listed companies' corporate governance. However, since most listed companies were transformed from state-owned enterprises, the Chinese securities market is still an emerging market of a transition economy, and the improvement in corporate governance is only at a very early stage.

The high concentration of state ownership and insider control make corporate control mechanisms and shareholder activism ineffective. The weak corporate governance has created an environment in which financial institutions, mainly investment funds, could perform an important monitoring role in corporate governance. They should be able to develop the capacity to recognise, demand, and expect good corporate governance in the form of composition and quality of boards, timely disclosure of material events and so on (Tenev et al., 2002).

Interviewees from both fund management companies and securities companies agreed that it was a good beginning that fund alliance intervened in corporate strategy, and that even if shareholder activism in China cannot create corporate value so far, it can prevent corporate value from being destroyed. ${ }^{66}$

\subsubsection{The improved legal environment}

"Whether or not the rights and interests of small and medium-sized shareholders can be protected will finally depend on the improvement of Chinese legal environment," Interviewee "J" said, "and a good market environment is very important to sound development of the stock market."

According to a new regulation issued in December 2004, the CSRC took some measures to protect minority shareholders. The regulation is expected to reinforce the stipulations of the Corporate Law, and these measures help institutional shareholders play a role in corporate governance (Feng, 2005).

\footnotetext{
${ }^{66}$ According to fund managers, domestic listed companies are classified into value-destroyed, valuetransferred and value-created, and a majority of listed companies destroy or transfer their corporate value. http://business.sohu.com. Securities Time, $19^{\text {th }}$ July 2004.
} 
First, the right to speak and vote at important meetings of listed companies. This regulation details institutional stipulation on the protection of the rights and interests of small and medium-sized investors, and give such investors the right to speak and vote at important meetings of listed companies. Shareholders can exercise their voting rights during the general shareholders' meeting on such issues as the offering of additional shares and convertible bonds, the placement of shares to existing shareholders, moves toward asset restructuring, repayment of debts by shareholders from the stocks they hold, and plans for overseas listing. In addition, the approval of more than half of tradable shareholders of listed shares is required.

At present, the Corporate Law does accord voting rights in accordance with the shareholders' stock ownership. "Now we have such regulation particularly for the protection of small and medium-sized shareholders, all because, presently, there are too many problems in the securities market." Interviewee "J" said, "Such rights will greatly benefit small and medium-sized investors." Interviewees from financial institutions thought that such regulation would not only help protect shareholder rights, but also facilitate the development of Chinese stock market.

Second, online voting system. According to the regulation, listed companies are encouraged to offer an online voting platform in addition to live meetings, and shareholders can vote either by themselves or by proxy through Internet.

Interviewee "G" said that the degree of participation in corporate operational policy decisions by small and medium-sized shareholders was quite low, and those shareholders, especially ones with small shareholdings, lacked the motivation and means to oversee and restrict managers. He believed that the participation degree would be increased if there is an online voting system.

Interviewee " $\mathrm{D}$ " thought that an online voting platform was an innovation, as the online voting platform will not only reduce the cost of small and medium-sized shareholders gathering from all around the country for the shareholders' meeting, but also be more close to real public opinion. 
Third, greater independence. China now has a system of independent directors in place after three years of efforts. However, the system is far from perfect. In practice, the independent directors are rarely "independent." The regulation seeks to rectify the situation by giving these directors special rights in respect of related party transactions and the hiring and firing of accounting and audit firms. The regulation also requires companies to guarantee the appropriate working conditions for independent directors and work with them actively in discharging their responsibilities. It also lays down the conditions under which independent directors can be removed. They cannot be dismissed without proper reasons and if asked to leave before the expiration of their terms, the dismissal has to be made public.

Fourth, calls for wider participation. To ensure greater participation at shareholders' meetings, the regulation requires that a peremptory call be made before a shareholders' meeting. It stipulates that after a listed company notifies shareholders of a meeting, within three days after the registration of the stake ownership, the notice of the meeting should be made again.

According to interviewee " $F$," the requirements of peremptory call and dissemination of information seem like steps in the right direction for the protection of small shareholders' rights. However, in practice, these rights can also be deprived by a few big shareholders. For instance, although the board of directors may notify small and medium-sized shareholders about a meeting, they may not be told the exact and detailed content of the meeting. In such cases, they may merely endorse the board's decisions or, at best, abstain from voting.

\subsection{Conclusion}

This case study serves to illustrate the practice of financial institutions in corporate governance of listed Chinese companies. It is the first time that so many financial institutions took a collective action to object their portfolio company publicly in China. In this case, they never gave up their efforts to fight for rights of tradable shareholders during the dispute, and have achieved a limited amount of success. Just as interviewee " $A$ " hoped, this event was a good turn to push tradable shareholders to get their voice heard. 
Due to the ineffective state ownership, expropriation of minority shareholder, small shareholdings of financial institutions, institutional shareholders who can play a more active and positive role in corporate governance do not have either the power or the incentive to do so. Additionally, the ineffective board of directors, independent directors, and supervisory board also affect the role of financial institutions in corporate governance. However, financial institutions have demonstrated themselves as the monitors of corporate management, representing the rights of minority shareholders. It appears that Chinese financial institutions have started to play an emerging and positive role in corporate governance. 


\section{Chapter Nine \\ Conclusion and Implications}

\subsection{Introduction}

This chapter summarises the main findings and draws conclusions, contributions and implications from the study. Section 2 reviews the research questions and summarises the main findings. Sections 3, 4, 5, and 6 discuss the empirical contributions, theoretical contributions, methodological contributions, and implications for policy makers and practitioners respectively. Section 7 indicates the limitations of this study. Section 8 highlights the several areas for future research.

\subsection{Research questions and summary of findings}

The objective of this thesis is to examine the role of Chinese financial institutions in corporate governance and their impact on firm performance. This thesis does not purport to test agency theory, partly because the Chinese market is not as efficient as agency theory assumes to be. Instead, agency theory is used as a theoretical perspective to guide the examination of, and to help explain the role of financial institutions.

Specifically, the following research questions are addressed:

(1) What are the characteristics of firms that attract institutional investment?

To answer this and the next two questions, interviews are employed to help provide background information on the role of financial institutions, act as a source of hypotheses, and help explain the factors underlying the relationships that are established.

Before investment, financial institutions perform quality research about listed companies in order to identify efficient firms for investing funds, thus directing scarce capital to its most efficient and consequently enhancing corporate efficiency. Good performance, tradable shareholdings, financial statements and annual report, quality of management, and investor communications are the characteristics of companies that attract institutional investment. 
(2) What are the expected and practical roles of financial institutions in corporate governance?

According to all interviewees, Chinese financial institutions should monitor and check controlling shareholders, protect the rights of minority shareholders, and thus improve firm performance and the value of shareholders. In practice, most securities companies are passive investors, while a minority of active investment funds help the companies in which they invest make financial forecasts, standardise their practices and improve their performance. The main methods of monitoring activities included communications with corporate management, voting in general shareholders' meetings, and making public comments. The reluctance of Chinese financial institutions' involvement in corporate governance can be explained by some factors, such as the small size of institutional shareholdings, poor protection of minority shareholders, lack of expertise to advise on corporate governance, a Chinese cultural aversion, costs of monitoring and checking corporate management, and the recent recession of securities companies.

(3) What are the factors that affect the role of Chinese financial institutions in corporate governance?

This less-than-desirable role of financial institutions in corporate governance can be attributed to a number of factors, including the great degree of ownership concentration, the segmented share structure, a premature regulatory environment, conflicts of interest, inadequate transparency and disclosure of financial information, and the existence of severe agency problems within financial institutions.

(4) What is the impact of institutional ownership on firm performance?

To answer this question, a secondary data analysis relates the governance role of financial institutions to their performance effect, aiming to generate a set of generalisable findings. Meanwhile, it helps with the choice of people and subjects for the interviews and the case study.

I use a large sample of 1,176 companies (3,273 observations) listed on both Shanghai and Shenzhen stock exchanges over the period from 2001 to 2003 to examine the relationship 
between institutional ownership and firm performance. I find that: (1) investment funds have a positive impact on firm performance and accounting performance influences their shareholdings; (2) the shareholdings of securities companies have no significant impact on firm performance. The results indicate that Chinese financial institutions (specifically investment funds) seem to have started to play a role in corporate governance and different financial institutions appear to have differing impacts on firm performance. I also find that state ownership has a negative influence on firm performance while legal person ownership has a positive effect on firm performance.

(5) How do financial institutions perform their role in practice?

To answer this question, a case study illustrates the role of financial institutions in corporate governance in a real-life context. It also examines the interactions between financial institutions and other corporate governance mechanisms and highlights the problems in corporate governance and effectiveness of other corporate governance mechanisms.

Like most listed companies in China, China Merchants Bank (CMB) had highly concentrated state and legal person ownership, a majority of non-tradable shares and low percentage of tradable shares. Such ownership structure prevented its corporate governance from being effective, and the ineffective corporate governance mechanisms prevented financial institutions from playing a more active and positive role in corporate governance. Though fund managers ultimately achieved a limited amount of success, their unyielding efforts demonstrate that the current financial institutions in China have started to play a role in corporate governance.

In addition, this case study suggests that the role of financial institutions as monitors of corporate governance is one of the corporate governance mechanisms and accordingly, its effectiveness depends on its interaction with other governance mechanisms and the effectiveness of these other mechanisms.

In summary, the interviews, secondary data analysis, and case study are combined to address two agency problems: one is the agency problem between managers and shareholders, and the other is the expropriation of minority shareholders by controlling 
shareholders. The interview evidence suggests that some investment funds act as monitors of corporate management, pressuring managers to improve corporate governance and firm performance. The secondary data analysis finds that investment funds can indeed improve firm performance. Thus, the participation of financial institutions in corporate governance appears to increase firm performance by ameliorating the manager-shareholder conflicts. Meanwhile, the case study implies that investment funds are the representatives of minority shareholder and protect their rights from being expropriating by controlling and/or majority shareholders.

However, this thesis suggests that the corporate governance role of Chinese financial institutions is still limited and emerging, due to a number of factors, such as the highly concentrated ownership, immature legal environment etc.

\subsection{Empirical contributions}

This thesis makes several empirical contributions to the literature on corporate governance and the monitoring role of financial institutions in a number of ways.

First, I contribute to the extant literature about corporate governance in general, and the role of financial institutions in corporate governance, in particular, by extending its research field to China, which is a unique departure from existing work on the UK and US. Listed Chinese companies are characteristic with a large volume of non-tradable stateowned and legal person shares, tradable shareholders are in an inferior position relative to the actual controllers. As a result, controlling shareholders always pursue their goals at the expense of minority shareholders. In this context, Chinese financial institutions are naturally expected to assume the responsibility to protect the minority. However, they are at a nascent stage of development, their role in corporate governance is limited.

Second, none of the limited number of empirical studies in the Chinese context that have examined the effect of legal person ownership on firm performance focuses on financial institutions. In addition, no prior study distinguishes types of financial institutions. This thesis fills the gap by focusing on the specific financial institutions, i.e., securities companies and investment funds. The results suggest that investment funds have a significant positive impact on firm performance, which is consistent with the notion that 
investment funds have the incentive and the ability to take part in the corporate governance on behalf of their investors. This thesis also finds that securities companies' shareholdings are not significantly correlated to firm performance, which could reflect problems like conflicts of interest and poor corporate governance that trouble securities companies. The findings indicate that differences in financial institutions lead to differing impacts on performance.

Third, it represents the first attempt to investigate the issues both from the perspectives of senior managers in financial institutions and board directors of listed companies they invested in. From their perspectives, I am able to provide balanced and/or more complete evidence on institutional involvement in relation to corporate governance in China. Moreover, the perceptions and expectations about the role of Chinese financial institutions elicited from board directors of listed companies help to explain the investor-company relations and the difference between the actual role and potential role of financial institutions in corporate governance.

Finally, it is also the first exploration of the recent phenomenon in China, with a case study of how fund managers attempted to influence corporate issues in a company in which they held shares. Fund managers' unyielding action demonstrates that their monitoring role in corporate governance is growing.

\subsection{Theoretical contributions}

\subsubsection{The explanatory power of agency theory}

A number of results reported in this thesis can be explained by agency theory arguments. First, according to agency theory, different ownership structures result in differing performance as firm performance differs depending on the presence and extent of the separation of ownership from control (Short, 1994). As discussed in Chapter 3, many empirical studies undertaken in developed economies have provided evidence to support it. The evidence reported in this thesis is also consistent with this proposition. The results suggest that institutional shareholdings of investment funds have a positive impact on firm performance while securities companies have no significant relationship with performance. In addition, state ownership has a negative effect while legal person ownership has a 
positive effect on firm performance. However, managerial ownership and foreign ownership have no significant relationship with performance.

Second, following the logic of agency theory, if certain shareholders act as monitors of management behaviour (either actively or by virtue of their mere presence), performance will be better than in firms where monitoring does not occur (assuming that managers will not operate effectively if monitoring does not take place). In China, due to the recent recession, conflicts of interest, and the weak corporate governance of securities companies, it is possible that they are less willing to expend resources to actively curb management inertia. Thus, I predict that ownership held by securities companies is likely to have no significantly positive impact on firm performance. By contrast, as investment funds appear to have more incentives to actively participate in the corporate issues, they are likely to have a positive impact on firm performance. Indeed, this is supported by the aforementioned recent anecdotal evidence on investment funds' attempt to veto corporate investment decisions. Hence, I predict that the percentage of ownership held by investment funds is likely to have a positive effect on firm performance.

As predicted, investment funds' ownership has a positive impact on firm performance. The result is consistent with the notion that investment funds have the incentive and the ability to take part in the corporate governance on behalf of their investors. The results also indicate that securities companies' shareholdings do not have a significant impact on firm performance, which could reflect the problems like the recent recession, goal conflicts, and poor corporate governance that trouble securities companies.

Third, this thesis provides evidence that there are not only principal-agent problems, but also principal-principal (e.g., minority-majority) problems in China, and the main agency problem is the expropriation of minority shareholders. The interviews suggest that the poor protection of minority shareholders is one of the causes that financial institutions are not willing to incur expense in intervening in listed companies' corporate issues. The case study suggests that one of the incentives that financial institutions intervened in corporate issues of listed companies is to restrict expropriation of minority shareholders by controlling/majority shareholders. However, the results of fights between minority and majority shareholders are always that minority rights are ultimately infringed by controlling/majority shareholders. 


\subsubsection{Implications for academics}

For academics, I am not optimistic that a straightforward application of agency theory would be fruitful in a transition economy like China that is characterised by a great deal of institutional differences compared with the developed economies.

First, agency theory assumes that markets are in or near an efficient equilibrium (Fama, 1980; Fama and Jensen, 1983a). However, China is a developing country with the characteristics of a transitional economy as well as an emerging market economy.

As Stiglitz (1997, p15) points out, there are “...special problems facing developing and transition economies, in which more markets are lacking, the markets that do exist may function less effectively, and information problems are more severe than in industrial countries simply because of the rapid change in the economic environment."

Indeed, recent research highlights the weak governance and underdeveloped institutional context in emerging economies (Peng and Heath, 1996; Khanna and Palepu, 1997). In China, because of its short history, the stock market is fraught with problems and is regarded as either of weak efficiency (e.g., Groenewold et al., 2003) or of non-efficiency (e.g., Seddighi and Nian, 2004). Highly concentrated ownership with a majority of nontradable state and legal person shares leads to insider control of companies. Tradable investors-(including financial institutions) are in an inferior position relative to the actual controllers and are randomly expropriated by the controlling shareholders and majority shareholders. Listed companies have not established an effective corporate governance system.

On the other hand, Chinese financial institutions account for a very small percentage in the market capitalisation and the number of shares. Most of them remain state-owned, currently many financial institutions suffer the same problems as listed companies, including insufficient internal control and entanglement of the interests of controlling shareholders and those of the shareholders and investors. In particular, most securities companies are loss-makers and still bear a print of SOEs with weak corporate governance, abuse of power and loose financial discipline. In such context, it is understandable that financial 
institutions (i.e., securities companies and investment funds) play a less-than-desirable role in corporate governance.

Since most scholars would agree that institutions matter in transition economies such as China, the effect of contextual variables should be adequately considered (Ryan and Schneider, 2003) when agency theory is employed in a transition economy. In this thesis, a range of such contextual variables have been considered, such as the inefficient stock market, the short history of financial institutions, and the premature legal environment, the weak corporate governance etc. when assessing the role of financial institutions in corporate governance in China.

Second, agency theory has not been adequately exploited to explain the uncertainty of outcome (Nilakant and Rao, 1994), and it overlooks other significant sources of uncertainty about outcome, i.e., goal conflicts. In agency relationships where there are several principals and/or agents, goal conflicts among the principals and/or the agents can result in outcome uncertainty. Business organisations pursue multiple and occasionally incompatible goals (Shetty, 1979). In such settings, variations in outcome may reflect multiple goals rather than effort aversion.

This thesis finds that securities companies do not have a significant impact on firm performance. One potential explanation is goal conflicts of securities companies, which lead to moral hazard in the relationship with their beneficial owners.

\subsection{Methodological contributions}

To my knowledge, this thesis is the first study to employ both qualitative and quantitative methods to address the practice of financial institutions' involvement in corporate governance in listed Chinese companies. As Bird (1992) suggests, research can be more fruitful when both major research methods - the quantitative and the qualitative - are utilised. Because these methods complement each other, the results are broadly consistent with either method.

The interviews provide evidence that investment funds have started to play a role in corporate governance while most securities companies are passive investors. The results of 
secondary data analysis indicate that investment funds' shareholdings have a positive impact on firm performance while securities companies have no such impact. This case study also implies that investment funds have began to play a positive role in corporate governance while most securities companies are still passive shareholders.

A combination of interviews, a case study, and secondary data analysis is used to achieve methodological triangulation, that is, to validate the results from one method by those from another. It is pleasing to obtain broadly consistent results from the three methods. Therefore, this thesis provides a more comprehensive picture of financial institutions' role in corporate governance of listed companies.

\subsection{Implications for policy makers and practitioners}

This thesis provides evidence to support that financial institutions (specifically investment funds) seem to have started to play a role in corporate governance in China, and they can be active monitors to limit the agency problem between managers and shareholders, and between majority shareholders and minority shareholders. This has implications for policy makers and practitioners in China.

\subsubsection{About the role of financial institutions in corporate governance}

Evidence suggests that investment funds have a positive impact on firm performance, while securities companies have no effect on performance due to their recent recession and weak corporate governance. This indicates that the efforts of securities regulators in China in promoting financial institutions as a corporate governance mechanism seem to be beneficial to corporate governance and performance, and so should be carried on. Future efforts should be made to improve the role of securities companies in corporate governance.

As discussed in Chapter 5, most securities companies are poor-performers and more risks were disclosed during the operation of most securities companies, who embezzled a large account of deposit funds of their clients to make investments and were unable to pay back the money due to investment failures as the stock market continued to fall. As a result, the industry has to be restructured to reallocate the resources. Most importantly, securities companies have to reposition themselves in the market place and upgrade their internal 
control. Thus, the restructure of securities industry has become urgent for securities regulators. It is pleasing that the reform of the industry is already on the way.

To standardise the operation of securities companies, the CSRC announced eight standard texts on $12^{\text {th }}$ April 2005 . One week later, the CSRC released a notice to standardise the appraisal and supervision of securities companies, in order to improve the whole reputation of the securities industry. Through these measures, the government attempts to encourage securities companies to improve their corporate governance to become really efficient and develop their role in corporate governance.

On the other hand, the interviews and case study also suggest that the less-than-desirable role of financial institutions can be attributed to several factors including the highly concentrated ownership, the segmented share structure, the imperfect legal environment, and the ineffective corporate governance of listed companies and financial institutions themselves. In addition, the results also indicate that current financial institutions seek a voice in firm strategies mainly in extreme case, such as in a huge loss.

Therefore, to further improve financial institutions' role in corporate governance, first, efforts are needed to gradually eliminate the drawbacks of the current system and to provide a good policy environment for financial institutions. For example, the high concentration of state and legal person ownership and the two-thirds non-tradable shares prevent financial institutions from exerting a real impact on corporate decisions. Thus, the segmented share structure should be eliminated, and the state shares should be gradually disposed. As introduced in Chapter 5, the reform of the segmented share structure has been carried out in April 2005.

Second, the governance, monitoring, and incentive mechanisms for financial institutions themselves should be improved in general. They should act in accordance with investor interest, in line with the current laws, and in due diligence rather than abuse their power of attorney in voting and using other resources.

Third, the regulations of the securities market and financial institutions are to be strengthened greatly. Additionally, the regulations of listed companies need to be improved in order to prevent adverse selection that favours wrongdoers, and to eliminate market 
distortion.

Fourth, financial institutions need to be encouraged to cultivate the notion of long-term investment and related investment culture and vote with "their hands" rather than with "their feet."

Finally, in practice, support is needed for financial institutions to understand how to participate in improving listed companies' corporate governance, how to decrease cost in participation, and how to increase effectiveness of participation.

In addition, as discussed in Chapter 4, financial institutions in developed economies play a proactive role as monitors of corporate management by means of thoughtfully and responsibly voting their shares, communicating with management and the press, and introducing proxy resolutions. Hence, efforts are also needed to promote international exchanges, to organise training and consulting to provide better education, and to realise global sharing of related experience and resources.

\subsubsection{About the corporate governance of Chinese companies in general}

Financial institutions are only one component of a larger governance 'package' consisting of internal and external mechanisms. While improving financial institutions' role in corporate governance, the internal and some other external mechanisms need to be strengthened as well. As discussed in Chapter 5, current internal mechanisms are ineffective and external mechanisms are relatively weak. In addition, as the case study suggests, the role of financial institutions depends on its interaction with other governance mechanisms and the effectiveness of these other mechanisms. Ineffective boards of directors, independent directors, and supervisory boards limit the role of Chinese financial institutions in corporate governance. Therefore, to improve corporate governance of Chinese companies, efforts should be made in the following ways.

First, the reform of the board of directors should be accelerated. First and foremost, the independence of the board should be strengthened. As required by the above mentioned the Guideline (CSRC, 2001), at least one-third of the board should consist of independent directors and independent directors should take control of the board and key board 
committees. Some board committees, such as those in charge of auditing, nomination, and evaluation and remuneration, should comprise solely of independent directors. Independent directors should arrange regular meetings without the presence of the management and other non-independent directors. Also, the chairman of the board should avoid becoming CEO of the company. In case such an arrangement becomes inevitable, the board should designate a leading independent director to coordinate with other independent directors. The senior management should regularly report to the board and the board should regularly examine the plan of the personnel development of senior management. In addition, the board should establish a self-evaluation system to strengthen the efficiency of board operation.

Second, the functions of the supervisory board should be clearly defined. The supervisory board is set up to monitor insiders and the management in the corporate framework in China. However, as discussed earlier, "strong management and weak supervisory board" becomes the reality. In addition, listed companies have engaged independent directors, and many have established board committees comprised mainly of independent directors. The rise in the role of independent directors prompts debate on whether independent directors and supervisors have overlapping functions.

With the global development of corporate governance and the opening of the Chinese capital market, independent directors will play a more important role in corporate governance in the long run. However, there is still room for the supervisory board to contribute to the improvement of corporate governance. Clearly defined supervisor functions and increased supervisor independence will help in this regard. In the end, the efficient use of resources will require that the monitoring and supervising roles be performed by a single entity. By then whether to elect a supervisory board or not should be a choice of listed companies.

Third, to induce directors and top executives to act in the best interest of shareholders and companies, efforts are needed to set up a dynamic, performance-oriented, market based, and long-term compensating scheme, including a comprehensive compensation mechanism, a proper compensation structure, and fair rules of game in determining directors and management compensation. For example, the portion of fixed compensation can be gradually decreased and variable compensation based on equity and the firm performance 
can be increased at the same time, so that directors and managers will share the outcome of firm development.

Finally, the institutional environment and implementation for information disclosure should be perfected.

\subsection{Limitations}

This study has several limitations.

First, publicly listed companies represent only a small subset of Chinese enterprises-a clean and perhaps better-performed group of enterprises that were chosen to be listed on the two stock exchanges. Clearly, they are not the representative of all enterprises in China, state or non-state. The empirical study suffers unavoidably from a sample selection bias. Therefore, the results must be treated with caution.

Second, I examine the role of securities companies and investment funds in China through interview, secondary data analysis, and case study. Therefore, the results obtained through these methods should be interpreted as the role of the specific financial institutions, rather than financial institutions in general.

Third, in China, only the institutional ownership in top ten shareholders is disclosed. Information is not readily available on other small and scattered institutional shareholdings. So the research is restrained by the use of publicly available data on institutional ownership. Thus, the relationship between institutional ownership and firm performance should be understood in a suggestive rather than decisive way.

Fourth, as one of the corporate governance mechanisms, institutional monitoring can both enhance operating performance and prevent fraud (Yeh et al., 2002). This thesis mainly focuses on the impact of institutional ownership on firm performance. The conformance role of financial institutions is not fully tested. 
Fifth, due to the limited studies on the role of financial institutions on corporate governance in emerging economies, this thesis mostly reviews the literature focused on the US and UK, which are characterised by a great deal of institutional differences compared with China.

Finally, the role of financial institutions in corporate governance of listed Chinese companies is still an emerging field of research and many uncertainties are involved, such as immature legal environment.

\subsection{Avenues for future research}

The limitations recognised in this study provide avenues for further research.

First, instead of just focusing on securities companies and investment funds, it would be useful and meaningful for future research to explore the role of other types of Chinese financial institutions (e.g., commercial banks and insurance companies).

Second, as most prior studies focus on the impact of institutional ownership on firm performance, more work can be undertaken to examine the influence of institutional ownership on fraud prevention and earnings management.

Third, an effective corporate governance system is important to all companies and financial institutions are no exception. This thesis provides evidence that corporate governance of financial institutions is one of the factors that affect the execution of their role in corporate governance. Therefore, it should be another interesting topic to research on corporate governance of financial institutions themselves.

Fourth, due to the problems of agency theory, other relevant theories, such as stakeholder theory, stewardship theory, could be considered to explore the role of financial institutions in corporate governance of listed companies.

Finally, it would be interesting to compare the findings with those obtained from similar economies in future research. 


\section{Appendices}

\section{Appendix 1 Interview schedule of Chapter Six}

\section{Panel A To financial institutions:}

1. What are the characteristics of firms that attract financial institutions?

2. How do you communicate with your portfolio companies before investment?

(1) How often, by what means and with whom do you contact with your target(s) before investment?

(2) What topics are generally covered during the communication before investment?

(3) What benefits do you get from the communication?

3. How do you communicate with portfolio companies after investment?

(1) How often, by what means and with whom do you contact with your target(s) after investment?

(2) What topics are generally covered during the communication after investment?

(3) How is attendance at shareholder meetings and voting? (Have you sit on the BoD or SB of your portfolio companies?)

4. What do you think about the investor relationship?

5. What do you think about the financial institutions' role in corporate governance of listed companies?

6. What is your role in corporate governance?

7. What are the factors affecting your intervention in corporate governance of listed companies?

\section{Panel B To board directors from portfolio companies}

1. What do you think about the role of your financial institution(s) in corporate governance and its effectiveness?

2. How does your company do if your financial institution wants to communicate with you about corporate governance?

3. How does your company deal with your financial institution's requests?

4. How is your relation with your financial institution(s)? 


\section{Appendix 2 The effect of institutional ownership on firm performance on a contemporaneous basis}

This table reports the fixed effects estimation of effect of institutional ownership on firm performance. The sample consists of 1,176 firms (3,273 observations) listed on the Shanghai and Shenzhen stock exchanges over the period of 2001-2003. (1) Tobin's Q: (market value of equity + book value of long-term debt + book value of short-term debt)/book value of total assets. (2) ROA: the ratio of net profit before extraordinary items divided to the average book value of total assets. (3) INST: the ratio of the number of shares held by securities companies and investment funds to the total number of shares in issue. (4) INST_S: the ratio of the number of shares held by securities companies to the total number of shares in issue. (5) INST_F: the ratio of the number of shares held by investment funds to the total number of shares in issue. (6) STATEO: the ratio of the number of shares owned by the state and state-owned legal persons to the total number of shares in issue. (7) LPO: the percentage of total shares held by domestic corporations and other non-individual entities. I deduct the non-tradable shares held by securities companies from total legal-person shareholdings to avoid double count. (8) MAO: the percentage of stock owned by managers. (9) FORO: the percentage of shares held by foreign investors. (10) HERF_5: the average of the sum of squares of percentage of shares held by each top five shareholder. (11) LEVE: the ratio of the total value of debt by the book value of total assets. (12) TANG: the ratio of net fixed assets over total assets. (13) SIZE: the natural logarithm of firm's annual sales. (14) YED1: year dummy 1 that takes the value of 1 for year 2001, and zero otherwise. (15) YED2, year dummy 2 that takes the value of 1 for year 2002, and zero otherwise. Separate regressions were undertaken because STATEO and LPO are highly correlated with each other $(\beta=-0.828)$. White Statistics is the White test on heteroskadasticity that follows a chi-square distribution. T-values based on White's (1980) corrected standard errors are in parentheses. ${ }^{* * *},{ }^{* *}$ and ${ }^{*}$ denote significance at the 1 per cent, 5 per cent and 10 per cent level (two-tailed), respectively. 
Panel A The impact of institutional ownership on Tobin's $Q$

\begin{tabular}{|c|c|c|c|c|}
\hline & Equation (1) & Equation (1) & Equation (2) & Equation (2) \\
\hline \multirow[t]{2}{*}{ INST } & $0.714^{*}$ & $0.647^{*}$ & & \\
\hline & $(1.86)$ & $(1.90)$ & & \\
\hline \multirow[t]{2}{*}{ INST_S } & & & 1.427 & 1.406 \\
\hline & & & $(1.56)$ & $(1.37)$ \\
\hline \multirow[t]{2}{*}{ INST_F } & & & $3.483^{* * *}$ & $3.455^{* * *}$ \\
\hline & & & $(4.19)$ & $(4.16)$ \\
\hline \multirow[t]{2}{*}{ STATEO } & $-0.387^{* * *}$ & & $-0.107^{* *}$ & \\
\hline & $(-8.07)$ & & $(-2.54)$ & \\
\hline \multirow[t]{2}{*}{ LPO } & & $0.212^{* * *}$ & & $0.146^{* *}$ \\
\hline & & $(5.08)$ & & (1.99) \\
\hline \multirow[t]{2}{*}{ MAO } & 6.112 & 6.213 & 0.539 & 0.542 \\
\hline & $(0.75)$ & $(0.78)$ & $(0.88)$ & $(0.88)$ \\
\hline \multirow[t]{2}{*}{ FORO } & 0.022 & 0.043 & 0.669 & 0.678 \\
\hline & $(0.12)$ & $(0.21)$ & $(1.09)$ & $(1.12)$ \\
\hline \multirow[t]{2}{*}{ HERF_5 } & $3.105^{* *}$ & $3.237^{* *}$ & $5.177^{* *}$ & $5.126^{* *}$ \\
\hline & $(2.07)$ & $(2.11)$ & $(2.89)$ & $(2.88)$ \\
\hline \multirow[t]{2}{*}{ TANG } & $-0.518^{* * *}$ & $-0.634^{* * *}$ & $-0.182^{*}$ & $-0.183^{*}$ \\
\hline & $(-4.03)$ & $(-4.71)$ & $(-1.87)$ & $(-1.88)$ \\
\hline \multirow[t]{2}{*}{ LEVE } & $0.131^{* *}$ & $0.134^{* *}$ & $0.938^{* * *}$ & $0.939^{* * *}$ \\
\hline & $(3.01)$ & $(3.17)$ & $(24.02)$ & $(24.05)$ \\
\hline \multirow[t]{2}{*}{ SIZE } & $-0.028^{* *}$ & $-0.036^{*}$ & $-0.309^{* * *}$ & $-0.400^{* * *}$ \\
\hline & $(-2.09)$ & $(-1.89)$ & $(-18.84)$ & $(-18.85)$ \\
\hline YED1 & yes & yes & yes & yes \\
\hline YED2 & yes & yes & yes & yes \\
\hline \multirow[t]{2}{*}{ CONS } & $2.112^{* * *}$ & $2.302^{* * *}$ & $7.062^{* * *}$ & $7.133^{* * *}$ \\
\hline & $(5.39)$ & $(5.48)$ & $(20.86)$ & $(21.06)$ \\
\hline Adj. $R^{2}$. & 0.201 & 0.175 & 0.408 & 0.411 \\
\hline D-W Statistic & 1.995 & 2.001 & 2.012 & 1.978 \\
\hline$F$-Statistic & $21.360^{* * *}$ & $18.920^{* * *}$ & $21.068^{* * *}$ & $19.548^{* * *}$ \\
\hline White Statistic & $385.479^{* * *}$ & $391.155^{* * *}$ & $56.287^{* * *}$ & $60.163^{* * *}$ \\
\hline Observations & 3273 & 3273 & 3273 & 3273 \\
\hline
\end{tabular}


Panel B The impact of institutional ownership on ROA

\begin{tabular}{|c|c|c|c|c|}
\hline & Equation (1) & Equation (1) & Equation (2) & Equation (2) \\
\hline \multirow[t]{2}{*}{ INST } & $0.104^{*}$ & $0.108^{*}$ & & \\
\hline & $(1.90)$ & $(1.83)$ & & \\
\hline \multirow[t]{2}{*}{ INST_S } & & & 0.066 & 0.067 \\
\hline & & & $(0.26)$ & $(0.27)$ \\
\hline \multirow[t]{2}{*}{ INST_F } & & & $0.141^{*}$ & $0.144^{*}$ \\
\hline & & & $(1.86)$ & $(1.92)$ \\
\hline \multirow[t]{2}{*}{ STATEO } & $-0.018^{*}$ & & $-0.017^{*}$ & \\
\hline & $(-1.87)$ & & $(-1.69)$ & \\
\hline \multirow[t]{2}{*}{ LPO } & & $0.005^{*}$ & & $0.068^{* *}$ \\
\hline & & $(1.87)$ & & $(2.35)$ \\
\hline \multirow[t]{2}{*}{ MAO } & 1.102 & 1.104 & 0.067 & 0.067 \\
\hline & $(0.44)$ & $(0.46)$ & $(0.35)$ & $(0.35)$ \\
\hline \multirow[t]{2}{*}{ FORO } & 0.022 & 0.027 & 0.096 & 0.095 \\
\hline & $(0.45)$ & $(0.44)$ & $(0.97)$ & $(0.96)$ \\
\hline \multirow[t]{2}{*}{ HERF_5 } & 0.137 & 0.171 & 0.056 & 0.043 \\
\hline & $(0.28)$ & $(0.36)$ & $(0.10)$ & $(0.08)$ \\
\hline \multirow[t]{2}{*}{ TANG } & $-0.202^{* * *}$ & $-0.189^{* * *}$ & $-0.124^{* * *}$ & $-0.131^{* * *}$ \\
\hline & $(-5.47)$ & $(-5.15)$ & $(-4.10)$ & $(-4.23)$ \\
\hline \multirow[t]{2}{*}{ LEVE } & $-0.154^{* * *}$ & $-0.151^{* * *}$ & $-0.197^{* * *}$ & $-0.178^{* * *}$ \\
\hline & $(-13.86)$ & $(-13.75)$ & $(-16.20)$ & $(-15.34)$ \\
\hline \multirow[t]{2}{*}{ SIZE } & $-0.014^{* *}$ & $-0.015^{* *}$ & $-0.034^{* * *}$ & $-0.027^{* * *}$ \\
\hline & $(-2.71)$ & $(-2.84)$ & $(-6.57)$ & $(-6.32)$ \\
\hline YED1 & yes & yes & yes & yes \\
\hline YED2 & yes & yes & yes & yes \\
\hline \multirow[t]{2}{*}{ CONS } & $0.146^{*}$ & $0.147^{*}$ & $0.531^{* * *}$ & $0.540^{* * *}$ \\
\hline & (1.94) & $(1.72)$ & $(5.04)$ & $(5.13)$ \\
\hline Adj. $R^{2}$ & 0.193 & 0.178 & 0.274 & 0.275 \\
\hline D-W Statistic & 1.903 & 1.998 & 1.907 & 1.925 \\
\hline$F$-Statistic & $2.913^{* * *}$ & $3.161^{* * *}$ & $2.938^{* * *}$ & $3.065^{* * *}$ \\
\hline White Statistic & $57.821^{* * *}$ & $59.213^{* * *}$ & $47.251^{* * *}$ & $50.338^{* * *}$ \\
\hline Observations & 3273 & 3273 & 3273 & 3273 \\
\hline
\end{tabular}




\section{Appendix 3 The impact of institutional ownership on ROE}

This table reports the fixed effects estimation of effect of institutional ownership on firm performance. The sample consists of 1,176 firms (3,273 observations) listed on the Shanghai and Shenzhen stock exchanges over the period of 2001-2003. (1) ROE: the ratio of net profit before extraordinary items divided by the average of owners' equity during the year. (2) INST: the ratio of the number of shares held by securities companies and investment funds to the total number of shares in issue. (3) INST_S: the ratio of the number of shares held by securities companies to the total number of shares in issue. (4) INST_F: the ratio of the number of shares held by investment funds to the total number of shares in issue. (5) STATEO: the ratio of the number of shares owned by the state and state-owned legal persons to the total number of shares in issue. (6) LPO: the percentage of total shares held by domestic corporations and other non-individual entities. I deduct the non-tradable shares held by securities companies from total legal-person shareholdings to avoid double count. (7) MAO: the percentage of stock owned by managers. (8) FORO: the percentage of shares held by foreign investors. (9) HERF_5: the average of the sum of squares of percentage of shares held by each top five shareholder. (10) LEVE: the ratio of the total value of debt by the book value of total assets. (11) TANG: the ratio of net fixed assets over total assets. (12) SIZE: the natural logarithm of firm's annual sales. (13) YED1: year dummy 1 that takes the value of 1 for year 2001, and zero otherwise. (14) YED2: year dummy 2 that takes the value of 1 for year 2002, and zero otherwise. Separate regressions were undertaken because STATEO and LPO are highly correlated with each other $(\beta=-0.828)$. White Statistics is the White test on heteroskadasticity that follows a chi-square distribution. $T$-values based on White's (1980) corrected standard errors are in parentheses. ${ }^{* * *},{ }^{* *}$ and ${ }^{*}$ denote significance at the 1 per cent, 5 per cent and 10 per cent level (two-tailed), respectively. 


\begin{tabular}{|c|c|c|c|c|}
\hline & Equation (1) & Equation (1) & Equation (2) & Equation (2) \\
\hline \multirow[t]{2}{*}{ INST } & $0.847^{*}$ & $0.827^{*}$ & & \\
\hline & (1.89) & $(1.78)$ & & \\
\hline \multirow[t]{2}{*}{ INST_S } & & & 0.331 & 0.594 \\
\hline & & & $(0.99)$ & $(0.98)$ \\
\hline \multirow[t]{2}{*}{$I N S T_{-} F$} & & & $1.093^{* *}$ & $1.062^{* *}$ \\
\hline & & & $(2.41)$ & $(2.40)$ \\
\hline \multirow[t]{2}{*}{ STATEO } & $-0.717^{*}$ & & $-0.763^{*}$ & \\
\hline & $(-1.79)$ & & $(-1.89)$ & \\
\hline \multirow[t]{2}{*}{ LPO } & & $0.452^{*}$ & & $1.643^{* *}$ \\
\hline & & $(1.82)$ & & $(2.30)$ \\
\hline \multirow[t]{2}{*}{ MAO } & 2.307 & 2.345 & 3.256 & 3.466 \\
\hline & $(0.90)$ & $(0.99)$ & $(0.15)$ & $(0.16)$ \\
\hline \multirow[t]{2}{*}{ FORO } & 0.139 & 0.142 & 0.137 & 0.128 \\
\hline & $(0.21)$ & $(0.24)$ & $(0.06)$ & $(0.04)$ \\
\hline \multirow[t]{2}{*}{ HERF_5 } & 2.152 & 2.165 & 3.016 & 2.658 \\
\hline & $(1.55)$ & $(1.56)$ & $(1.62)$ & (1.59) \\
\hline \multirow[t]{2}{*}{ TANG } & $-0.826^{* *}$ & $-0.818^{* *}$ & $-0.484^{* *}$ & $-0.449^{* *}$ \\
\hline & $(-3.26)$ & $(-3.16)$ & $(-2.32)$ & $(-2.23)$ \\
\hline \multirow[t]{2}{*}{ LEVE } & $0.237^{*}$ & $0.243^{*}$ & $0.282^{*}$ & $0.281^{*}$ \\
\hline & $(1.86)$ & $(1.90)$ & $(1.94)$ & $(1.93)$ \\
\hline \multirow[t]{2}{*}{ SIZE } & $-0.132^{* *}$ & $-0.138^{* *}$ & $-0.115^{*}$ & $-0.146^{*}$ \\
\hline & $(-2.19)$ & $(-2.23)$ & $(-1.85)$ & $(-1.72)$ \\
\hline YED1 & yes & yes & yes & yes \\
\hline YED2 & yes & yes & yes & yes \\
\hline \multirow[t]{2}{*}{ CONS } & $5.016^{* * *}$ & $5.017^{* * *}$ & $-1.989^{* *}$ & $-2.081^{* *}$ \\
\hline & $(8.35)$ & $(8.40)$ & $(-2.71)$ & $(-2.78)$ \\
\hline Adj. $R^{2}$ & 0.128 & 0.125 & 0.143 & 0.151 \\
\hline D-W Statistic & 1.866 & 1.758 & 1.836 & 1.872 \\
\hline$F$-Statistic & $21.860^{* * *}$ & $18.720^{* * *}$ & $19.132^{* * *}$ & $18.657^{* * *}$ \\
\hline White Statistic & $58.866^{* * *}$ & $60.259^{* * *}$ & $42.513^{* * *}$ & $44.129^{* * *}$ \\
\hline Observations & 3273 & 3273 & 3273 & 3273 \\
\hline
\end{tabular}




\section{Appendix 4 The impact of institutional ownership on MBR}

This table reports the fixed effects estimation of effect of institutional ownership on firm performance. The sample consists of 1,176 firms (3,273 observations) listed on the Shanghai and Shenzhen stock exchanges over the period of 2001-2003. (1) MBR: the ratio of share prices on the last trading day of each year times the number of total outstanding shares over the book value of equity. (2) INST: the ratio of the number of shares held by securities companies and investment funds to the total number of shares in issue. (3) INST_S: the ratio of the number of shares held by securities companies to the total number of shares in issue. (4) INST F: the ratio of the number of shares held by investment funds to the total number of shares in issue. (5) STATEO: the ratio of the number of shares owned by the state and state-owned legal persons to the total number of shares in issue. (6) LPO: the percentage of total shares held by domestic corporations and other nonindividual entities. I deduct the non-tradable shares held by securities companies from total legal-person shareholdings to avoid double count. (7) MAO: the percentage of stock owned by managers. (8) FORO: the percentage of shares held by foreign investors. (9) HERF_5: the average of the sum of squares of percentage of shares held by each top five shareholder. (10) LEVE: the ratio of the total value of debt by the book value of total assets. (11) TANG: the ratio of net fixed assets over total assets. (12) SIZE: the natural logarithm of firm's annual sales. (13) YED1: year dummy 1 that takes the value of 1 for year 2001, and zero otherwise. (14) YED2: year dummy 2 that takes the value of 1 for year 2002, and zero otherwise. Separate regressions were undertaken because STATEO and LPO are highly correlated with each other $(\beta=-0.828)$. White Statistics is the White test on heteroskadasticity that follows a chi-square distribution. $T$-values based on White's (1980) corrected standard errors are in parentheses. ${ }^{* * *},{ }^{* *}$ and ${ }^{*}$ denote significance at the 1 per cent, 5 per cent and 10 per cent level (two-tailed), respectively. 


\begin{tabular}{|c|c|c|c|c|}
\hline & Equation (1) & Equation (1) & Equation (2) & Equation (2) \\
\hline \multirow[t]{2}{*}{ INST } & $0.872^{*}$ & $0.896^{*}$ & & \\
\hline & $(1.88)$ & $(1.90)$ & & \\
\hline \multirow[t]{2}{*}{ INST_S } & & & 1.778 & 1.098 \\
\hline & & & $(0.49)$ & $(0.50)$ \\
\hline \multirow[t]{2}{*}{ INST_F } & & & $1.28^{* *}$ & $1.571^{* *}$ \\
\hline & & & $(2.23)$ & $(2.24)$ \\
\hline \multirow[t]{2}{*}{ STATEO } & $-0.526^{* * *}$ & & $-0.199^{* *}$ & \\
\hline & $(-4.03)$ & & $(-3.17)$ & \\
\hline \multirow[t]{2}{*}{ LPO } & & $0.265^{* *}$ & & $0.743^{* *}$ \\
\hline & & $(2.79)$ & & $(2.67)$ \\
\hline \multirow[t]{2}{*}{ MAO } & 4.012 & 4.088 & 2.131 & 1.366 \\
\hline & $(0.62)$ & $(0.65)$ & $(0.05)$ & $(0.05)$ \\
\hline \multirow[t]{2}{*}{ FORO } & 0.086 & 0.079 & 1.438 & 1.382 \\
\hline & $(0.45)$ & $(0.42)$ & $(0.31)$ & $(0.32)$ \\
\hline \multirow[t]{2}{*}{ HERF_5 } & $3.112^{* *}$ & $3.209^{* *}$ & $1.942^{* *}$ & $1.958^{* *}$ \\
\hline & $(2.78)$ & $(2.98)$ & $(2.25)$ & $(2.30)$ \\
\hline \multirow[t]{2}{*}{ TANG } & $-0.712^{* * *}$ & $-0.721^{* * *}$ & $-2.364^{* *}$ & $-2.584^{* *}$ \\
\hline & $(-5.02)$ & $(-5.23)$ & $(-2.28)$ & $(-2.36)$ \\
\hline \multirow[t]{2}{*}{ LEVE } & $0.232^{* *}$ & $0.243^{* *}$ & $1.532^{* *}$ & $1.526^{* *}$ \\
\hline & $(3.01)$ & (3.19) & (2.09) & $(2.01)$ \\
\hline \multirow[t]{2}{*}{ SIZE } & $-0.231^{* *}$ & $-0.226^{* *}$ & $-1.059^{* *}$ & $-1.073^{* *}$ \\
\hline & $(-2.38)$ & $(-2.35)$ & $(-2.14)$ & $(-2.17)$ \\
\hline YED1 & yes & yes & yes & yes \\
\hline YED2 & yes & yes & yes & yes \\
\hline \multirow[t]{2}{*}{ CONS } & $4.529^{* *}$ & $4.446^{*}$ & $2.486^{* *}$ & $2.967^{* *}$ \\
\hline & $(2.01)$ & $(1.91)$ & $(2.48)$ & $(2.52)$ \\
\hline Adj. $R^{2}$ & 0.238 & 0.213 & 0.195 & 0.196 \\
\hline D-W Statistic & 2.204 & 2.205 & 2.124 & 2.068 \\
\hline$F$-Statistic & $35.274^{* * *}$ & $33.126^{* * *}$ & $32.287^{* * *}$ & $31.425^{* * *}$ \\
\hline White Statistic & $168.532^{* * *}$ & $165.463^{* * *}$ & $160.219^{* * *}$ & $162.752^{* * *}$ \\
\hline Observations & 3273 & 3273 & 3273 & 3273 \\
\hline
\end{tabular}




\section{Appendix 5 The impact of institutional ownership using dummy variable on firm performance}

This table reports the fixed effects estimation of effect of institutional ownership on firm performance. The sample consists of 1,176 firms (3,273 observations) listed on the Shanghai and Shenzhen stock exchanges over the period of 2001-2003. (1) Tobin's Q: (market value of equity + book value of long-term debt + book value of short-term debt)/book value of total assets. (2) ROA: the ratio of net profit before extraordinary items divided to the average book value of total assets. (3) INST: the ratio of the number of shares held by securities companies and investment funds to the total number of shares in issue. (4) STATEO: the ratio of the number of shares owned by the state and state-owned legal persons to the total number of shares in issue. (5) LPO: the percentage of total shares held by domestic corporations and other non-individual entities. I deduct the non-tradable shares held by securities companies from total legal-person shareholdings to avoid double count. (6) MAO: the percentage of stock owned by managers. (8) FORO: the percentage of shares held by foreign investors. (7) HERF_5: the average of the sum of squares of percentage of shares held by each top five shareholder. (9) LEVE: the ratio of the total value of debt by the book value of total assets. (10) TANG: the ratio of net fixed assets over total assets. (11) SIZE: the natural logarithm of firm's annual sales. (12) YED1: year dummy 1 that takes the value of 1 for year 2001, and zero otherwise. (13) YED2: year dummy 2 that takes the value of 1 for year 2002, and zero otherwise. Separate regressions were undertaken because STATEO and LPO are highly correlated with each other $(\beta=-0.828)$. White Statistics is the White test on heteroskadasticity that follows a chi-square distribution. T-values based on White's (1980) corrected standard errors are in parentheses. ${ }^{* * *},{ }^{* *}$ and ${ }^{*}$ denote significance at the 1 per cent, 5 per cent and 10 per cent level (two-tailed), respectively.

\begin{tabular}{lcccc}
\hline & Tobin's Q & Tobin's Q & ROA & ROA \\
\hline INDU & $0.813^{* *}$ & $0.835^{* *}$ & $0.201^{* *}$ & $0.213^{* *}$ \\
& $(2.07)$ & $(2.12)$ & $(2.12)$ & $(2.01)$ \\
STATEO & $-0.528^{* * *}$ & & $-0.038^{* *}$ & \\
LPO & $(-7.12)$ & & $(-2.03)$ & \\
& & & & $0.004^{*}$ \\
MAO & & $\left(4.265^{* * *}\right.$ & & $(1.89)$ \\
& 5.745 & 5.465 & 1.744 & 1.823 \\
FORO & $(0.78)$ & $(0.67)$ & $(0.85)$ & $(0.90)$ \\
& 0.056 & 0.067 & 0.023 & 0.026 \\
HERF_5 & $(0.25)$ & $(0.34)$ & $(0.58)$ & $(0.60)$ \\
& $3.175^{* *}$ & $3.264^{* *}$ & 0.201 & 0.223 \\
TANG & $(2.48)$ & $(2.59)$ & $(0.43)$ & $(0.49)$ \\
& $-0.657^{* * *}$ & $-0.683^{* * *}$ & $-0.198^{* * *}$ & $-0.190^{* * *}$ \\
LEVE & $(-5.03)$ & $(-5.36)$ & $(-4.98)$ & $(-4.90)$ \\
& $0.149^{* *}$ & $0.158^{* *}$ & $-0.206^{* * *}$ & $-0.208^{* * *}$ \\
SIZE & $(2.91)$ & $(3.02)$ & $(-14.78)$ & $(-14.80)$ \\
& $-0.062^{*}$ & $-0.078^{* *}$ & $-0.023^{* *}$ & $-0.025^{* *}$ \\
YED1 & $(-1.89)$ & $(-2.13)$ & $(-3.05)$ & $(-3.09)$ \\
YED2 & yes & yes & yes & yes \\
CONS & yes & yes & yes & yes \\
& $1.823^{* * *}$ & $1.936^{* * *}$ & 0.114 & 0.121 \\
Adj. $R^{2}$ & $(6.12)$ & $(6.27)$ & $(1.56)$ & $(1.60)$ \\
D-W Statistic & 0.197 & 0.208 & 0.192 & 0.201 \\
$F$-Statistic & 1.896 & 1.788 & 1.992 & 1.896 \\
White Statistic & $27.360^{* * *}$ & $23.720^{* * *}$ & $2.885^{* * *}$ & $2.946^{* * *}$ \\
Observations & $368.466^{* * *}$ & $382.368^{* * *}$ & $58.762^{* * *}$ & $60.185^{* * *}$ \\
& 3273 & 3273 & 3273 & 3273 \\
\hline
\end{tabular}




\section{Appendix 6 Interview schedule of Chapter Eight}

1. Why did the fund managers take a collective action to vote against the proposal?

2. What are the factors that affect the outcome of this dispute?

3. Why did the fund alliance achieve a limited amount of success?

4. What do you think about the roles of the board of directors, independent directors, and supervisory board of the bank in this case?

5. What do you think of the significance of this case?

6. What do you think about shareholder activism in China?

(1) What is the current role of financial institutions in corporate governance of listed companies?

(2) Is there any condition that will facilitate shareholder activism in China? 


\section{Bibliography}

Agrawal, A. R., Jaffe, J., and Mandelker, G. (1992) The post-merger performance of acquiring firms: A re-examination of an anomaly. Journal of Finance 47, 1605-1621.

Admati, A. R., Pfleiderer, P., and Zechner, J. (1994) Large shareholder activism, risk sharing, and financial market equilibrium. Journal of Political Economy 102, 10971130.

Agrawal, A and Knoeber, C. R. (1996) Firm performance and mechanisms to control agency problems between managers and shareholders. Journal of Financial and Quantitative Analysis 31, 377-397.

Agrawal, A. and Mendelker, G. (1990) Large shareholders and the monitoring of managers: The case of antitakeover amendments. Journal of Financial and Quantitative Analysis $23,143-161$.

Allen, F., Qian, J., and Qian, M. (2005) Law, finance and economic growth in China. Journal of Financial Economics 77, 57-116.

Allen, F. and Santomero, A. M. (1998) The theory of financial intermediation. Journal of Banking and Finance 21, 1461-1485.

Anderson, C. W. and Campbell, T. L. (2004) Corporate governance of Japanese banks. Journal of Corporate Finance 10, 327-354.

Antle, R. and Smith, A. (1986) An empirical investigation of the relative performance evaluation of corporate executives. Journal of Accounting Research 24, 1-39.

Aoki, M. (1995) Controlling insider control: Issues of corporate governance in transition economies, in M. Aoki and H. Kim (eds.) Corporate Governance in Transition Economies: Insider Control and the Role of Banks. The World Bank: Washington, DC.

Aoki, M., Patrick, H., and Sheard, P. (1994) The Japanese main bank system: An introductory overview, in Aoki, M. and H. Patrick (eds.) The Japanese Main Bank System: Its Relevance for Developing and Transforming Economies. Oxford University Press: Oxford.

Aoki, M. and Kim, H. K. (1995) Corporate governance in transition economies. Finance and Development 32, 20-22. 
Arrow, K. (1985) The economics of agency, in J. W. Pratt and R. J. Zeckhauser (eds.) Principals and Agents: The Structure of Business. Harvard Business School Press: Boston.

Bai, C., Liu, Q., Lu, J., Song, F., and Zhang, J. (2002) Corporate governance and protection of the rights of minority shareholders in China. Working Paper, the University of Hong Kong.

Bai, C., Liu, Q., Lu, J., Song, F., and Zhang, J. (2004) Corporate governance and market valuation in China. Journal of Comparative Economics 32, 599-616.

Baiman, S. (1990) Agency research in managerial accounting: A second look. Accounting, Organisations and Society 15, 341-371.

Balatbat, M. C., Maria, C. A., Taylor, S. L., and Walter, T. S. (2004) Corporate governance, insider ownership and operating performance of Australian initial public offerings. Accounting and Finance 44, 299-328.

Band, D. (1992) Corporate governance: Why agency theory is not enough. European Management Journal 10, 453-460.

Barclay, M. and Holderness, C. (1989) Private benefit from control of public corporations. Journal of Financial Economics 25, 371-395.

Barclay, M. and Holderness, C. (1991) Control of corporations by active block investors. Journal of Applied Corporate Finance 4, 68-77.

Barney, J. B. and Ouchi, W. G. (1986) Organisational Economics. Jossey-Bass: San Francisco.

Barth, J. R., Brumbaugh, R. D. Jr., and Wilcox, J. A. (2000) The repeal of Glass-Steagall and the advent of broad banking. Journal of Economic Perspectives 14, 191-204.

Bathala, C. T., Moon, K. P., and Rao, R. P. (1994) Managerial ownership, debt policy, and the impact of institutional holdings: An agency perspective. Financial Management 23, $38-50$.

Baumol, W. J. (1959) Business Behaviour, Value and Growth. Macmillan: New York.

Bebchuk, L., Kraakman, R., and George, T. (1998) Stock pyramids, cross-ownership, and dual class equity: The creation and agency costs of separating control from cash flow rights. Working Paper, Harvard Law School. 
Beiner, S., Drobetz, W., Schmid, F., and Zimmermann, H. (2004) Is board size an independent corporate mechanism? Kyklos 57, 327-356.

Belev, B. (2003) Institutional investors in Bulgarian corporate governance reform: Obstacles or facilitators? Journal of World Business 38, 361-374.

Berglof, E. and Perotti, E. (1994) The governance structure of the Japanese financial keiretsu. Journal of Financial Economics 36, 259-284.

Bergstrom, C. and Rydqvist, K. (1990a) The determinants of corporate ownership: An empirical study on Swedish data. Journal of Banking and Finance 14, 237-253.

Bergström, C. and Rydqvist, K. (1990b) Ownership of equity in dual-class firms. Journal of Banking and Finance 14, 255-269.

Berkman, H., Cole, R. A., and Fu, J. (2002) From state to state: Improving corporate governance when the government is a large block holder. Working Paper, University of Auckland, New Zealand.

Berkman, H., Cole, R. A., and Fu, J. (2005) Agency conflicts, expropriation and firm value: Evidence form securities-market regulation in China. Working Paper, University of Auckland, New Zealand.

Berle, A. and Means, G. (1932) The Modern Corporation and Private Property. Macmillan: New York.

Bertrand, M. and Mullainathan, S. (2001) Are CEOs rewarded for luck? The ones without principals are. Quarterly Journal of Economics 116, 901-932.

Bethel, J., Liebeskind, J., and Opler, T. (1998) Block share purchases and corporate performance. Journal of Finance 53, 605-635.

Bhagat, S. and Black, B. (2000) Board independence and long-term firm performance. Working Paper, University of Colorado.

Bhagat, S. and Black, B. (2002) The non-relation between board independence and longterm firm performance. Journal of Corporation Law 27, 231-273.

Bhagat, S. and Jefferis, R. H. (1988) You can fool some of the people all of the time: The proxy voting process and antigreenmail charter amendments. Working Paper, University of Chicago.

Bird, M. (1992) Combing quantitative and qualitative methods: A case study of the implementation of the Open College Policy, in J. Brannen (eds.) Mixing Methods: Qualitative and Quantitative Research. Avebury: England. 
Birkett, B. S. (1986) The recent history of corporate audit committees. The Accounting Historians Journal 13, 109-124.

Black, B. S. (1992a) Institutional investors and corporate governance: The case for institutional voice. Journal of Applied Corporate Finance, Fall, 19-32.

Black, B. S. (1992b) Agents watching agents: The promise of institutional investor voice. UCLA Law Review 39, 811-893.

Black, B. S. and Coffee, J. C. (1994) Hail Britannia?: Institutional investor behaviour under limited regulation. Michigan Law Review 92, 1997-2087.

Black, B. S. (2001) Does corporate governance matter? A crude test using Russia data. University of Pennsylvania Law Review 149, 2131-2150.

Black, B. S., Jang, H., Kim, W., and Mark, J. (2002) Does corporate governance affect firm value? Evidence from Korea. Working Paper, Stanford Law University.

Blair, M. M. (1995) Ownership and Control: Rethinking Corporate Governance for the Twenty-first Century. Brookings Institution: Washington, DC.

Boatright, J. R. (1992) Conflict of interest: An agency analysis, in N. E. Bowie and R. E. Freeman (eds.) Ethics and Agency Theory. Oxford University Press: New York.

Bodie, Z. and Crane, D. B. (1999) The design and production of new retirement savings products. Journal of Portfolio Management 25, 77-82.

Boehmer, E. (1999) Corporate governance in Germany: Institutional background and empirical results. Working Paper, University of Georgia.

Boehmer, E. (2000) Who controls Germany? An exploratory analysis. Working Paper, University of Georgia.

Bosch, H. (1993) Corporate Practices and Conduct. Business Council of Australia. Melbourne.

Boubakri, N., Cosset, J., and Guedhami, O. (2005) Postprivatisation corporate governance: The role of ownership structure and investor protection. Journal of Financial Economics 76, 369-399.

Bouma, G. D. and Atkinson, G. B. (1997) A Handbook of Social Science Research. Oxford University Press: New York.

Brancato, C. K. (1995) The Brancato Report on Institutional Investment, Equity Turnover and Investment Strategies. The Conference Board: Chicago.

Brancato, C. K. (1997) Institutional Investors and Corporate Governance: Best Practices for Increasing Corporate Value. Irwin: Chicago. 
Bricker, R. and Chandar, N. (2000) Where Berle and Means went wrong: A reassessment of capital market agency and financial reporting. Accounting, Organisations and Society $25,529-554$.

Brickley, J. A., Lease, R. C., and Smith, C. W. (1988) Ownership structure and voting on antitakeover amendments. Journal of Financial Economics 20, 267-291.

Brickley, J. A., Lease, R. C., and Smith, C. W. (1994) Corporate voting: Evidence from charter amendment proposals. Journal of Corporate Finance 1, 5-31.

Bromiley, P. (1991) Testing a model of corporate risk taking and performance. Academy of Management Journal 34, 37-59.

Brown, C. (1998) Rise of the institutional equity funds: Implications for managerialism. Journal of Economic Issues 32, 803-821.

Brownstein, A. and Kirman, I. (2004) Can a board say no when shareholders say yes? Responding to majority vote resolutions. The Business Lawyer 60, 23-77.

Bryman, A. (1994) Quantitative and qualitative research: Further reflections on their integration, in J. Brannen (eds.) Mixing Methods: Qualitative and Quantitative Research. Avebury: England.

Bryman, A. (2004) Social Research Methods ( $2^{\text {nd }}$ edn.) Oxford University Press: Oxford.

Burgess, R. G. (1982) Multiple strategies in field research, in R. G. Burgess (eds.) Field Research: A Sourcebook and Field Manual. George Allen and Unwin: London.

Business Intelligence (2001) Emerging and transforming securities industry in China--Markets, institutions and legal system. No. 7.

Byrd, W. (1983) Enterprise-level reform in Chinese state-owned industry. American Economic Review 73, 329-332.

Byrne, J. A. (1999) The Teddy Roosevelts of corporate governance. Business Week, $31^{\text {st }}$ May, $75-79$.

Cadbury Committee (1992) Report of the Committee on the Financial Aspect of Corporate Governance. Gee \& Co: London.

Caldwell, C. and Karri, R. (2005) Organisational governance and ethical systems: A covenantal approach to building trust. Journal of Business Ethics 58, 249-259.

Cannella, A. A. and Monroe, M. J. (1997) Contrasting perspectives on strategic leaders: Toward a more realistic view of top managers. Journal of Management 23, 213-238.

Carcello, J. V. and Neal, T. L. (1999) Audit committee characteristics and auditor reporting. Working Paper, University of Tennessee. 
Carleton, W. T., Nelson, J. M., and Weisbach, M. (1998) The influence of institutions on corporate governance through private negotiations: Evidence from TIAA-CREF. Journal of Finance 53, 1335-1362.

Carpenter, M. and Westphal, J. (2001) The strategic context of external network ties: Examining the impact of board appointments on board involvement in strategic decision making. Academy of Management Journal 44, 639-660.

Carroll, A. B. (1996) Business and Society: Ethics and Stakeholder Management. SouthWestern College Publishing, Cincinnati: $\mathrm{OH}$.

Cernat, L. (2004) The emerging European corporate governance model: Anglo-Saxon, Continental, or still the century of diversity? Journal of European Public Policy 11, $147-166$.

Cha, L. M. (2001) The future of China's capital markets and the role of corporate governance. Luncheon speech at China Business Summit, $18^{\text {th }}$ April, Vice Chairman, the China Securities Regulatory Commission.

Chaganti, R. and Damanpour, F. (1991) Institutional ownership, capital structure and firm performance. Strategic Management Journal 12, 479-491.

Chandar, N. (1996) Investment company reporting: Earnings management and valuation implications of closed-end fund restricted security investments. Working Paper, Case Western Reserve University.

Chang, E. C. and Wong, S. M. (2002) Corporate governance, political interference, and corporate performance of China's listed companies. Working Paper, the University of Hong Kong.

Chang, E. C. and Wong, S. M. (2004) Political control and performance in China's listed firms. Journal of Comparative Economics 32, 617-636.

Charkham, J. P. (1994) Keeping Good Company: A Study of Corporate Governance in Five Countries. Clarendon Press: Oxford.

Cheffins, B. R. (1999) Current trends in corporate governance: Going from London to Milan via Toronto. Duke Journal of Comparative and International Law 10, 5-42.

Cheffins, B. R. (2001) History and the global corporate governance revolution: The UK perspective. Business History 43, 87-118.

Cheffins, B. R. (2004) Mergers and the evolution of patterns of corporate ownership and control: The British experience. Business History 46, 256-284. 
Chen, D. H., Fan, J. P., and Wong, T. J. (2002) Do politicians jeopardise professionalism? Decentralisation and the structure of Chinese corporate boards. Working Paper, Shanghai University of Finance and Economics, and Hong Kong University of Science and Technology.

Chen, D. H., Fan, J. P., and Wong, T. J. (2004) Politically-connected CEOs, corporate governance and post-IPO performance of China's partially privatised firms. Working Paper, Shanghai University of Finance and Economics, and Hong Kong University of Science and Technology.

Chen, H. Y., Hexter, J. L., and Hu, M. Y. (1993) Management ownership and corporate value. Managerial and Decision Economics 14, 335-346.

Chen, J. (2001) Ownership structure as corporate governance mechanism: Evidence form China's listed companies. Economic of Planning 34, 53-72.

Chen, J. and Huang, Q. (2001) Comparison of governance structures of Chinese enterprises with different types of ownership. Working Paper, Chinese Academy of Social Science.

Chen, J. and Strange, R. (2004) The evolution of corporate governance in China. Working Paper, University of London.

Chen, K. and Wang, J. (2004) A comparison of shareholder identity and governance mechanisms in the monitoring of listed companies in China. Working Paper, Hong Kong University of Science and Technology.

Chen, K: and Yuan, H. (2004) Earnings management and capital resource allocation: Evidence from China's accounting-based regulation of rights issues. The Accounting Review 79, 645-665.

Chen, Y. (1998) Ownership structure and corporate performance: Some Chinese evidence. Working Paper, San Francisco State University.

Chen, Y. M. and Gong, S. C. (2000) Ownership structure and corporate performance Some Chinese evidence. Advances in Pacific Basin Financial Market 6, 177-193.

Chen, Z. W. (2003) Capital markets and legal development: The China case. China Economic Review 14, 451-472.

Chhibber, P. K. and Majumdar, S. K. (1999) Foreign ownership and profitability: Property rights, control, and the performance of firms in Indian industry. Journal of Law and Economics 42, 209-238.

Chiang, H. (2005) An empirical study of corporate governance and corporate governance. Journal of American Academy of Business 6, 95-101. 
China Daily (2004) China securities companies post 2003 loss: Report. $4^{\text {th }}$ February.

China Economic Times (2002) The development of securities investment funds in China. $20^{\text {th }}$ August.

China Finance Yearbook (2004) The development summary of China's commercial banks. China Finance Yearbook Publishing House: Beijing, China.

Chiou, J. and Lin, Y. (2005) The structure of corporate ownership: A comparison of China and Taiwan's security markets. Journal of American Academy of Business 6, 123-127.

Chirinko, R., Ees, H. V., Garretsen, H., and Sterken, E. (2004) Assessing corporate control mechanisms in the Netherlands. German Economic Review 5, 119-138.

Cho, M. H. (1998) Ownership structure, investment, and the corporate value: an empirical analysis. Journal of Financial Economics 47, 103-121.

Cho, N. (1999) Minority shareholders seek reforms to protect rights in emerging markets. Wall Street Journal, $13^{\text {th }}$ September, A39.

Choi, W. and Cho, S. (2003) Shareholder activism in Korea: An analysis of PSPD's activities. Pacific-Basin Finance Journal 11, 349-363.

Chowdhury, S. and Geringer, J. M. (2001) Institutional ownership, strategic choices and corporate efficiency: Evidence from Japan. Journal of Management Studies 38, 271-291. Chung, K. H. and Pruitt, S. (1994) A simple approximation of Tobin's q. Financial Management 23, 70-74.

Claessens, S. and Djankov, S. (1999a) Enterprise performance and management turnover in the Czech Republic. European Economic Review 43, 1115-1124.

Claessens, S. and Djankov, S. (1999b) Ownership concentration and corporate performance in the Czech Republic. Journal of Comparative Economics 27, 498-513.

Claessens, S. and Fan, J. P. (2002) Corporate governance in Asia: A survey. International Review of Finance 3, 71-103.

Claessens, S., Simeon D., Fan, J. P., and Lang, L. H. (1999) Expropriation of minority shareholders: Evidence from East Asia corporations. Working Paper, the World Bank.

Claessens, S., Simeon D., Fan, J. P., and Lang, L. H. (2000) The separation of ownership and control in East Asian corporations. Journal of Financial Economics 58, 81-112.

Claessens, S. and Fan, J. P. (2002) Corporate governance in Asia: A survey. International Review of Finance 3, 71-103. 
Clarkson, M. B. (1995) A stakeholder framework for analysing and evaluating corporate social performance. Academy of Management Review 20, 92-117.

Clearfield, A. M. (2005) With friends like these, who needs enemies? The structure of the investment industry and its reluctance to exercise governance oversight. Corporate Governance 13, 114-120.

Coase, R. (1937) The nature of the firm. Economica 4, 386-405.

Coffee, J. C. (1988) Shareholders versus managers: The strain in the corporate web, in J. C. Coffee, L. Lowenstein, and S. Rose-Ackerman (eds.) Knights, Raiders, and Targets. Oxford University Press: New York.

Coffee, J. C. (1991) Liquidity versus control: The institutional investor as corporate monitor. Columbia Law Review 91, 1277-1368.

Coles, J. W., McWilliams, V. B., and Sen, N. (2001) An examination of the relationship of governance mechanisms to performance. Journal of Management 27, 23-50.

Collier, P. (1997) Corporate Governance and Audit Committees, in M. Sherer and S. Turley (eds.) Current Issues in Auditing. Paul Chapman Publishing: London.

Conrad, A. F. (1988) Beyond managerialism: Investor capitalism? University of Michigan Journal of Law Reform 22, 117-178.

Coombes, P. and Watson, M. (2001) Giving new life to the corporate governance reform agenda for emerging markets. Directorship 27, 4-8.

Cooper, B. J., Chow, L., and Wei, T. (2002) The development of auditing standards and the certified public accounting profession in China. Managerial Auditing Journal 17, 383389.

Cotter, J. and Silvester, M. (2003) Board and monitoring committee independence. Abacus $39,211-232$.

Coughlan, A. and Schmidt, R. (1985) Executive compensation, management turnover, and firm performance: An empirical investigation. Journal of Accounting and Economics 7, $43-66$.

Craswell, A. T., Taylor, S. T., and Saywell, R. A. (1997) Ownership structure and corporate performance: Australian evidence. Pacific-Basin Finance Journal 5, 301-323.

Cubbin, J. and Leech, D. (1983) The effect of shareholding dispersion on the degree of control in British companies: Theory and measurement. Economic Journal 93, 351-369. 
Cuervo, A. and Villalonga, B. (2000) Explaining the variance in the performance effects of privatisation. Academy of Management Review 25, 581—590.

Cyert, R. M. and March, J. G. (1963) A Behavioural Theory of the Firm. Prentice-Hall: Englewood Cliffs, NJ.

Dahya, J., Karbhari, Y., and Xiao, J. Z. (2002) The supervisory board in Chinese listed companies: Problems, Causes, Consequences and Remedies. Asia Pacific Business Review 9, $118-137$.

Dan, B. (2005) The growth of firms dominates the future stock markets. Beijing Business Today, $6^{\text {th }}$ March.

David, E. W. (2004) The case study, the interview and the issues: A personal reflection, in C. Humphrey and B. Lee (eds.) The Real Life Guide to Accounting Research: A Behindthe-Scenes View of Using Qualitative Research Methods. Elsevier: London.

David, P. and Kochhar, R. (1996) Barriers to effective corporate governance by institutional investors: Implications for theory and practice. European Management Journal 14, 457-466.

Davis, J. H., Schoorman, F. D., and Donaldson, L. (1997) Toward a stewardship theory of management. Academy of Management Review 22, 20-47.

Day, J. and Taylor, P. (2004) Institutional change and debt-based corporate governance: A comparative analysis of four transition economies. Journal of Management and Governance 8, 73-115.

de Andres, P., Azofra, V., and Lopez, F. (2005) Corporate boards in OECD countries: Size, composition, function and effectiveness. Corporate Governance 13, 197-210.

DeAngelo, H. and Rice, E. M. (1983) Antitakeover charter amendments and stockholder wealth. Journal of Financial Economics 11, 329-360.

DeAngelo, H., DeAngelo, L., and Rice, E. (1984) Going private: Minority freezouts and stockholder wealth. Journal of Law and Economics 27, 367-402.

Deacon, D., Bryman, A., and Fenton, N. (1998) Collision or collusion? A discussion of the unplanned triangulation of quantitative and qualitative research methods. International Journal of Social Research Methodology 1, 47-63.

Dechow, P. M., Sloan, R. G., and Sweeney, A. P. (1996) Causes and consequences of earning s manipulation: An analysis of firms subject to enforcement actions by the SEC. Contemporary Accounting Research 13, 1-36. 
Del Guercio, D. (1996) The distorting effect of the prudent-man laws on institutional equity investments. Journal of Financial Economics 40, 31-62.

Demb, A. and Neubauer, F. F. (1992) The corporate board: Confronting the paradoxes. Long Range Planning 25, 9-20.

Demsetz, H. (1983) The structure of ownership and the theory of the firm. Journal of Law and Economics 26, 375-390.

Demsetz, H. and Lehn, K. (1985) The structure of corporate ownership: Causes and consequences. Journal of Political Economy 93, 1155-1177.

Demsetz, H. and Villalonga, B. (2001) Ownership structure and corporate performance. Journal of Corporate Finance 7, 209-233.

Denis, D. J. and Denis, D. K. (1994) Majority owner - managers and organisational efficiency. Journal of Corporate Finance 1, 91-118.

Dewenter, K. and Malatesta, P. H. (2001) State-owned and privately owned firms: An empirical analysis of profitability, leverage and labour intensity. American Economic Review 91, 320-334.

Dharwadkar, B., George, G., and Brandes, P (2000) Privatisation in emerging economies: An agency theory perspective. Academy of Management Review 25, 650-669.

Di, J. Y. (2004) Pension funds tend to invest on listed companies with dispersed ownership. Shenzhen Special Zone Daily, $6^{\text {th }}$ September.

Diamond, D. W. (1984) Financial intermediation and delegated monitoring. Review of Economic Studies 51, 393-414.

Diamond, D. W. (1996) Financial intermediation as delegated monitoring: A simple example. Economic Quarterly 82, 51-66.

Dipchand, C. R., Zhang, Y., and Ma, M. (1994) The Chinese Financial System. Greenwood Press: Westport.

Dockery, E. and Herbert, W. (2000) Corporate governance and enterprises restructuring in transition economies: Evidence from privatised Polish companies. Managerial Finance $26,80-92$.

Donaldson, L. (1990) The ethereal hand: Organisational economies and management theory. Academy of Management Review 15, 369-381. 
Donaldson, L. and Davis, J. H. (1989) CEO governance and shareholder returns: Agency theory or stewardship theory. Paper presented at the annual meeting of the Academy of Management, Washington, DC.

Donaldson, L. and Davis, J. H. (1991) Stewardship theory or agency theory: CEO governance and shareholder returns. Australian Journal of Management 16, 49-64.

Donaldson, T. and Preston, L. (1995) The stakeholder theory of the corporation: Concepts, evidence, and implications. Academy of Management Review 20, 65-91.

Doucouliagos, C. (1994) A note on the evolution of homo economics. Journal of Economics Issues 3, 877-883.

Drucker, P. F. (1976) The Unseen Revolution: How Pension Fund Socialism Came to America. Heinemann: London.

Drucker, P. F. (1986) To end the raiding roulette game. Across the Board 5, 30-39.

Duggal, R. and Millar, J. A. (1999) Institutional ownership and firm performance: The case of bidder returns. Journal of Corporate Finance 5, 103-117.

Dyck, A. and Zingales, L. (2002) The corporate governance role of the media. NBER Working Paper.

Easterbrook, F. H. and Fischel, D. R. (1983) Voting in corporate law. Journal of Law and Economics 26, 395-427.

Easterby-Smith, M., Thorpe, R., and Lowe, A. (1991) Management Research - An Introduction. Sage: London.

Edelman, L. (1992) Legal ambiguity and symbolic structures: Organisational mediation of civil rights law. American Journal of Sociology 97, 1531-1576.

Editorial Note (2003) China Economic Review 14, 203 -205.

Eisenberg, T., Sundgren, S., and Wells, M. (1998) Large board size and decreasing firm value in small firms. Journal of Financial Economics 48, 35-54.

Eisenhardt, K. M. (1989) Agency theory: An assessment and review. Academy of Management Review 14, 57-74.

Eng, L. L. (1999) Comparing changes in stockholdings of different institutional investors. Journal of Investing 1, 46-50.

Ersoy-Bozcuk, A. and Lasfer, M. A. (2001) Changes in shareholder groups' holdings and corporate monitoring: The UK evidence. Working Paper, City University Business School. 
Evan, W. M. and Freeman, R. E. (1988) A stakeholder theory of the modern corporation: Kantian capitalism, in T. L. Beauchamp and N. E. Bowie (eds.) Ethical Theory and Business. Prentice Hall: Englewood Cliffs, NJ.

Evans, J. and Weir. C. (1995) Decision processes, monitoring, incentives and large firm performance in the UK. Management Decision 33, 32-38.

Faccio, M. and Lasfer, M. A. (2000) Do occupational pension funds monitor companies in which they hold large stakes? Journal of Corporate Finance 6, 71-110.

Faccio, M., Lang, L. H., and Young, L. (2001) Dividends and expropriation. The American Economic Review 91, 54-78.

Fama, E. F. (1980) Agency problems and the theory of the firm. Journal of Political Economy 88, 288-307.

Fama, E. and Jensen, M. (1983a) Separation of ownership and control. Journal of Law and Economics 26, 301-325.

Fama, E. and Jensen, M. (1983b) Agency problems and residuals claims. Journal of Law and Economics 26, 327-349.

Fan, D. K., Lau, C., and Wu, S. (2002) Corporate Governance Mechanisms. Working Paper, the Chinese University of Hong Kong and Nanjing University.

Fan, J. P. and Wong, T. J. (2002) Do external auditors perform a corporate governance role in emerging markets? Evidence from East Asia. Working Paper, Hong Kong University of Science and Technology.

Feng, J.H. (2005) Giving a voice to small shareholders. Beijing Review, $9^{\text {th }}$ May.

Fosberg, R. H. (2004) Agency problems and debt financing: Leadership structure effects. Corporate Governance 4, 31-38.

Frank, R. H. (1994) Microeconomics and Behaviour. McGraw-Hill: New York.

Franks, J. and Mayer, C. (1998) Bank control, takeovers and corporate governance in Germany. Journal of Banking and Finance 22, 1385-1403.

Franks, J., Mayer, C., and Rossi, S. (2003) The organisation and evolution of ownership and control. Finance Working Paper, ECGI.

Fredman, A. J. and Wiles, R. (1998) How Mutual Funds Work. New York Institute of Finance: New York.

Freeman, R. E. (1984) Strategic Management: A Stakeholder Approach. Pitman Press: Boston.

Freeman, R. E. and Reed, D. L. (1983) Stockholders and stakeholders: A new perspective on corporate governance. California Management Review 25, 337-359. 
Frye, M. (2001) Equity-based compensation for employees: Firm performance and determinants. Working Paper, University of Central Florida.

Furubotn, E. and Pejovich, S. (1973) Property rights, economic decentralisation and the evolution of the Yugoslav firm, 1965-1972. Journal of Law and Economics 16, 175207.

Garten, H. (1992) Institutional investors and the new financial order. Rutgers Law Review $44,585-674$.

Gedajlovic, E. and Shapiro, O. (1998) Management and ownership effects: Evidence from 5 countries. Strategic Management Journal 19, 533-555.

Gen, J. (2002) A Study of the Institutional Investors in China. The Publishing House of People's University of China: Beijing, China.

Gerson, J. and Barr, G. (1996) The structure of corporate control and ownership in a regulatory environment unbiased toward one-share-one-vote. Corporate Governance 4, $78-93$.

Gibson, M. S. (2003) Is corporate governance ineffective in emerging markets? Journal of Financial and Quantitative Analysis 38, 231-250.

Gillan, S. L. and Stark, L. T. (2000) Corporate governance proposals and shareholder activism: The role of institutional investors. Journal of Financial Economics 57, 275305.

Gillan, S. L. and Starks, L. T. (2003) Corporate governance, corporate ownership, and the role of institutional investors: A global perspective. Journal of Applied Finance 13, 4 22.

Gilson, R. and Roe, M. (1993) Understanding the Japanese Keiretsu: Overlaps between corporate governance and industrial organisation. The Yale Law Journal 102, 871—906.

Goergen, M. (1998) Corporate governance and financial performance: A study of German and UK initial public offerings. Cheltenham.

Gompers, P. and Metrick, A. (2001) Institutional investors and equity prices. Quarterly Journal of Economics 116, 229-259.

Gompers, P., Ishiii, J., and Metrick, A. (2003) Corporate governance and equity prices. Quarterly Journal of Economics 118, 107-155.

Gordon, S. C. (1993) New deal for shareholders. The Wall Street Journal, $4^{\text {th }}$ February.

Gordon, R. H. and Li, W. (2003) Government as a discriminating monopolist in the financial market: The case of China. Journal of Public Economics 87, 283-312. 
Gorton, G. and Kahl, M. (1999) Blockholder identity, equity ownership structure and hostile takeover. No. 7123 NBER Working Paper.

Graves, S. B. (1988) Institutional ownership and corporate R\&D in the computer industry. Academy of Management Journal 31, 417-428.

Greenbury, Sir Richard (1995) Directors' Remuneration. Gee \& Co.: London.

Greene, W. H. (1999) Econometric Analysis. Prentice Hall: Englewood Cliffs, NJ.

Grier, P. and Zychowicz, E. J., (1994) Institutional investors, corporate discipline and the role of debt. Journal of Economics and Business 46, 1-11.

Groenewold, N., Tang, S. H., and Wu, Y. (2003) The efficiency of the Chinese stock market and the role of the bank. Journal of Asian Economics 14, 593-609.

Grossman, S. and Hart, O. (1988) One share-one vote and the market for corporate control. Journal of Financial Economics 20, 175-202.

Guercio, D. D. and Hawkins, J. (1999) The motivation and impact of pension fund activism. Journal of Financial Economics 52, 293-340.

Gul, F. A (1999) Government share ownership, investment opportunity set and corporate policy choices in China. Pacific-Basin Finance Journal 7, 157-172.

Gul, F. A. and Zhao, R. (2000) Corporate governance and performance in Chinese listed companies. Working Paper, City University of Hong Kong.

Hampel, Sir Ronnie (1998) Committee on Corporate Governance Final Report. January 1099, Gee Publishing Ltd: London.

Han, K. C. and Suk, D. Y. (1998) The effect of ownership structure on firm performance: Additional evidence. Review of Financial Economics 4, 143-155.

Handy, J. A. (1997) Using methodological triangulation in organisational research. Proceedings of the 1997 Annual Conference of the New Zealand Psychological Society (eds.) E. M. Habermann, Vol. Chapter 9.

Hanousek, J. and Kocenda, E. (2003) The impact of Czech mass privatisation of corporate governance. Journal of Economic Studies 30, 278-293.

Harris, M. and Raviv, A. (1978) Some results on incentive contracts with application to education and employment, health insurance, and law enforcement. American Economic Review 68, 20-30.

Hartzell, J. C. and Starks, L. T. (2003) Institutional investors and executive compensation. The Journal of Finance 6, 2351-2374.

Hawley, J. P. and Williams, A. T. (2000) The Rise of Fiduciary Capitalism. University of Pennsylvania Press: Philadelphia, PA. 
Hay, C. (1996) A state of disarray? Huttonomics, new labour and the contemporary British impasse. Renewal 4, 40-50.

Hayashi, F. (1982) Tobin's marginal Q and average Q: A neoclassical interpretation. Econometrica 50, 213-224.

Heard, J. E. and Sherman, H. D. (1987) Conflicts of interest in the proxy voting system. Investor Responsibility Research Centre: Washington, DC.

Healy, J. (2003) Corporate Governance and Wealth Creation in New Zealand. Dunmore Press Ltd: Palmerston North, NZ.

Hermalin, B. and Weisbach, M. (1988) The determinants of board composition. RAND Journal of Economics 19, 1155-1177.

Hermalin, B. and Weisbach, M. (1991) The effects of board composition and direct incentive on firm performance. Financial Management 20, 101-112.

Herman, E. S. (1981) Corporate Control, Corporate Power. Cambridge University Press: New York.

Higson, C. and Elliott, J. (1998) Post-takeover returns: The UK's evidence. Journal of Empirical Finance 5, 27-46.

Hill, C. L. and Jones, T. M. (1992) Stakeholder-agency theory. Journal of Management Studies 29, $131-154$.

Himmelberg, C., Hubbard, R. G., and Palia, D. (1999) Understanding the determinants of managerial ownership and the link between ownership and performance. Journal of Financial Economics 53, 353-384.

Hirschmann, A. O. (1970) Exit, Voice, and Loyalty. Harvard University Press: Cambridge, MA.

Hirsch, P., Michaels, S., and Friedman, R. (1987) "Dirty hands" versus "clean models." Theory and Society 16, 317-336.

Holderness, C., Kroszner, R., and Sheehan, D. (1999) Were the good old days that good? Changes in managerial stock ownership since the great depression. Journal of Finance $54,435-470$.

Holderness, C. and Sheehan, D. (1985) Raiders or saviors? The evidence on six controversial investors. Journal of Financial Economics 14, 555-579.

Holderness, C. and Sheehan, D. (1988) The role of majority shareholders in publicly held corporations: An exploratory analysis. Journal of Financial Economics 20, 317-346. 
Holland, J. B. (1995) The corporate governance role of financial institutions in their investee companies. Chartered Association of Certified Accountants, Research Report 46, November.

Holland, J. B. (1998) Influence and intervention by financial institutions in their investee companies. Corporate Governance 6, 249-263.

Holland, J. B. (1999) Financial reporting, private disclosure and the corporate governance role of financial institutions. Journal of Management and Governance 3, 161-187.

Holland, J. B. and Doran, P. (1998) Financial institutions, private acquisition of corporate information, and fund management. The European Journal of Finance 4, 129-155.

Hong Kong Economic Journal (1997) $19^{\text {th }}$ September.

Hoskisson, R. E., Eden, L., Lau, C. M., and Wright, M. (2000) Strategy in emerging economies. Academy of Management Journal 43, 249-267.

Hovey, M. (2002) Corporate governance, valuation and ownership in China: An empirical study of listed firms. Working Paper, Griffith University, Australia.

Hovey, M., Li, L., and Naughton, T. (2003) The relationship between valuation and ownership of listed firms in China. Corporate Governance 11, 112-122.

$\mathrm{Hu}, \mathrm{X}$. (2000) The state, enterprises and society in post-Deng China: Impact of the new round of SOE reform. Asian Survey 40, 641-657.

Huddart, S. (1993) The effect of a large shareholder on corporate value. Management Science 39, 1407-1421.

Hughes, K., MacKintosh, A. M., Hastings, G., Wheeler, C., Watson, J., and Inglis, J. (1997) Young people, alcohol, and designer drinks: A quantitative and qualitative study. British Medical Journal 314, 414-418.

Huson, M. (1997) Does governance matter?: Evidence from CalPERS intervention? Working Paper, University of Alberta.

Hutton, W. (1995) The State We Are In. Jonathan Cape/Random House: London.

Ingley, C. B. and van der Walt, N. T. (2004) Corporate governance, institutional investors and conflicts of interest. Corporate Governance 12, 534-551.

Interview (2000) The role of institutional investors in corporate governance: The case of Standard Life Investments. Corporate Governance 8, 81-85.

Ittner, C., Lambert, R., and Larcker, D. (2001) The structure and performance consequences of equity grants to employees of new economy firms. Working Paper, University of Pennsylvania. 
Jang, H. and Kim, J. (2002) Nascent stages of corporate governance in an emerging market: Regulatory change, shareholder activism and Samsung Electronics. Corporate Governance 10, 94-105.

Jarrell, G. and Poulsen, A. (1987) Shark repellents and stock prices: The effects of antitakeover amendments since 1980. Journal of Financial Economics 19, 127-168.

Jarrell, G., Brickley, J., and Netter, J. (1988) The market for corporate control: Empirical evidence since 1980'. Journal of Economic Perspectives 2, 49-68.

Jenkinson, T and Mayer, C. (1992) The assessment: Corporate governance and corporate control. Oxford Review of Economic Policy 8, 1-10.

Jensen, G. R., Solberg, D. P., and Zorn, T. S. (1992) Simultaneous determination of insider ownership, debt, and dividend policies. Journal of Financial and Quantitative Analysis $27,247-263$.

Jensen, M. C. (1983) Organisation theory and methodology. Accounting Review 56, 319338.

Jensen, M. C. (1986a) Agency costs of free cash flow, corporate finance, and takeovers. American Economic Review 76, 323-329.

Jensen, M. C. (1986b) The take-over controversy: Analysis and evidence. Midland Corporate Finance Journal 4, 6-32.

Jensen, M. C. (1989) Eclipse of the public corporation. Harvard Business Review 67, 6175.

Jensen, M. C. (1993) The modern industrial revolution, exit, and the failure of internal control systems. Journal of Finance 48, 831-880.

Jensen, M. C. and Meckling, W. (1976) Theory of the firm: Managerial behaviour, agency costs, and ownership structure. Journal of Financial Economics 3, 305-360.

Jensen, M. C. and Meckling, W. (1979) Rights and production functions: An application to labour-managed firms and codetermination. Journal of Business 52, 469-506.

Jensen, M. C. and Meckling, W. (1994) The nature of man. Journal of Applied Corporate Finance 7, 4-19.

Jensen, M. C. and Murphy, K. (1990) Performance pay and top-management incentives. Journal of Political Economy 98, 225-264.

Jensen, M. C. and Ruback, R. S. (1983) The market for corporate control: The scientific evidence. Journal of Financial Economics 11, 5-50. 
Jensen, M. C. and Smith, C. (1985) Stockholder, manager, and creditor interests: Application of agency theory, in E. I. Altman and M. G. Subrahmanyam (eds.) Recent Advances in Corporate Finance. Irwin: Homewoood.

Ji, D. S. (2005) The prospect of shareholder activism of investment funds in China. Working Paper, People's University of China.

Jing, H. (2004) Analysing the preference of financial institutions through one-year dataset. China Securities Journal, $26^{\text {th }}$ October.

Joh, S. W. (2003) Corporate governance and firm profitability: Evidence from Korea before economic crisis. Journal of Financial Economics 68, 287-322.

Johnson, H. F. (1993) Financial Institutions and Markets: A Global Perspective. McGraw Hill: New York.

Johnson, M., Porter, S., and Shackell, M. (1997) Stakeholder pressure and the structure of executive compensation. Working Paper, University of Michigan.

Johnson, S., La Porta, R., Lopez-de-Silanes, F., and Shleifer, A. (2000) Tunneling. The American Economic Review 90, 22-27.

Judge, W. Q., Naoumova, I., and Koutzevol, N. (2003) Corporate governance and firm performance in Russia: An empirical study. Journal of World Business 38, 385-396.

Kahn, C. and Winton, A. (1998) Ownership structure, speculation and shareholder intervention. Journal of Finance 53, 99-129.

Kang, J. L. and Stulz, R. (2000) Do banking shocks affect firm performance? An analysis of the Japanese experience. Journal of Business 73, 1-23.

Kang, J. K. and Shivdasani, A. (1995) Firm performance, corporate governance, and top executive turnover in Japan. Journal of Financial Economics 38, 29-58.

Kaplan, S. and Minton, B. (1994) Appointments of outsiders to Japanese boards: Determinants and implications for managers. Journal of Financial Economics 36, $225-257$.

Karpoff, J. M. (2001) The impact of shareholder activism on target companies: A survey of empirical findings. Working Paper, University of Washington.

Karpoff, J. M., Malatesta, P. H., and Walkling, R. A. (1996) Corporate governance and shareholder initiatives: Empirical evidence. Journal of Financial Economics 42, 365395.

Katz, D. and Kahn, R. L. (1978) The Social Psychology of Organisations. John Wiley \& Sons: New York. 
Keenoy, T. (1999) HRM as a hologram: A polemic. Journal of Management Studies 36, $1-23$.

Kennedy, P. (1998) A Guide to Econometrics ( $4^{\text {th }}$ edn.) Blackwell Publishing: Oxford.

Key, S. (1999) Toward a new theory of the firm: A critique of stakeholder "theory." Management Decision 37, 317-328.

Khanna, T. and Palepu, K. (1997) Why focused strategies may be wrong for emerging markets. Harvard Business Review 75, 41-51.

Khanna, T. and Palepu, K. (1999) Emerging market business groups, foreign investors, and corporate governance. No. 6955 NBER Working Paper.

Kidwell, D. S., Peterson, R. L., and Blackwell, D. W. (1993) Financial Institutions, Markets and Money. Dreyden: New York.

Kim, J. and Mahoney, J. (2005) Property rights theory, transaction costs theory, and agency theory: An organisational economics approach to strategic management. Managerial and Decision Economics 26, 223-242.

Kim, Y., Ho. I. S. M., and Giles, M. S. (2003) Developing institutional investors in People's Republic of China. World Bank Country Study Paper.

Kirsch, C. E. (1997) The Financial Services Revolution. Professional Publishing: Chicago.

Klein, A. (1998) Firm performance and board committee structure. Journal of Law and Economics 41, 275-299.

Kolb, R. W. (1994) Investments ( $3^{\text {rd }}$ eds.) Kolb.

Kochar, R. and David, P. (1996) Institutional investors and firm innovation: A test of competing hypotheses. Strategic Management Journal 17, 73-84.

Kohak, E. (1978) Idea and Experience: Husserl's Project of Phenomenology in Ideas. Chicago University Press: Chicago.

Kole, S. (1996) Managerial incentives and firm performance: Incentive or reward? Advances in Financial Economics 24, 119-149.

Krikorian, B. L. (1991) Fiduciary standards: Loyalty, prudence, voting proxies, and corporate governance, in A. W. Sametz and J. L. Bicksler (eds.) Institutional Investing: Challenges and Responsibilities of the $21^{\text {st }}$ Century. Business One Irwin: Homewood, IL.

Kumar, J. (2003) Ownership structure and corporate firm performance. Working Paper, Indira Gandhi Institute of Development Research.

Kuttner, R. (1999) A requiem for Glass-Steagall. Business Week, $15^{\text {th }}$ November, 28. 
Lambe, A. (2005) Audit committees step into the limelight. Accountancy Ireland 37, 4851.

Lane, P. J., Cannella, A. A., Jr., and Lubatkin, M. H. (1998) Agency problems as antecedents to unrelated mergers and diversification: Amihud and Lev reconsidered. Strategic Management Journal 19, 555-578.

Lang, L. H., Stulz, R. M., and Walkling, R. A. (1989) Managerial performance, Tobin's $q$ and the gains from successful tender offers. Journal of Financial Economics 24, 137154.

Lang, L. H. and Stulz, R. M. (1994) Tobin's Q, corporate diversification, and firm performance. Journal of Political Economy 102, 1248-1280.

La Porta, R., Lopez-de-Silanes, F., Shleifer, A., and Vishny, R. (1997) Legal determinants of external finance. Journal of Finance 52, 1131-1150.

La Porta, R., Lopez-de-Silanes, F., Shleifer, A., and Vishny, R. (1998) Law and finance. Journal of Political Economy 106, 1113-1155.

La Porta, R., Lopez-de-Silanes, F., and Shleifer, A. (1999a) Corporate ownership around the world. Journal of Finance 54, 471-517.

La Porta, R., Lopez-de-Silanes, F., Shleifer, A., and Vishny, R. (1999b) Investor protection and corporate valuation. No. 7403 NBER Working Paper, Cambridge, MA.

La Porta, R., Lopez-de-Silances, F., Shleifer, A., and Vishny, R. (2000) Investor protection and corporate governance. Journal of Financial Economics 58, 3-27.

La Porta, R., Lopez-de-Silances, F., Shleifer, A., and Vishny, R. (2002) Investor protection and corporate valuation. Journal of Finance 58, 1147-1170.

La Porta, R., Lopez-de-Silanes, F., and Shleifer, A. (2004) What works in securities laws? Unpublished mimeo, Harvard University.

Lee, K. (1993) Property rights and the agency problems in China's enterprise reform. Cambridge Journal of Economics 17, 179-194.

Lee, K. and Hahn, D. (2001) From Insider-Outsider Collusion to Insider Control in China's SOEs. Working Paper.

Leech, D. and Leaahy, J. (1991) Ownership structure, control type classifications and the performance of large British companies. Economic Journal 101, 1418-1437.

Leland, H. and Pyle, D. H. (1977) Information asymmetry, financial structure and financial intermediation. Journal of Finance 32, 371-388. 
Letza, S., Sun, X., and Kirkbride, J. (2004) Shareholding versus stakeholding: A critical review of corporate governance. Corporate Governance 12, 242-262.

Levinthal, D. (1988) A survey of agency models of organisations. Journal of Economic Behaviour and Organisation 9, 153-185.

Li, D. H., Moshirian, F., Nguyen, P., and Tan, L. W. (2005) Managerial ownership and firm performance: Evidence from China's privatisations. Working Paper, University of New South Wales, Australia.

Lin, C. (2001) Corporation and corporate governance in China's economic transition. Economic of Planning 34, 5-35.

Lin, T. W. (2004) Corporate governance in China: Recent development, key problems, solutions. Journal of Accounting and Corporate Governance 1, 1-23.

Lin, T. W. and Tang, Y. W. (2001) China's securities market and accounting disclosure requirements: Current problems and suggested solutions. Working Paper, University of Southern California.

Lin, Z. and Chen, F. (2004) An empirical study of audit 'expectation gap' in the people's republic of China. International Journal of Auditing 8, 93-115.

Lindenberg, E. B. and Ross, S. A. (1981) Tobin's q ratio and industrial organisation. Journal of Business 54, 1-32.

Linn, S. C. and McConnell, J. J. (1983) An empirical investigation of the impact of 'antitakeover amendments' on common stock prices. Journal of Financial Economics 11, $361-399$.

Lins, K. V. (2003) Equity ownership and firm value in emerging markets. Journal of Financial and Quantitative Analysis 38, 159-184.

Lipton, M. and Lorsch, J. (1992) A modest proposal for improved corporate governance. Business Lawyer 48, 59-77.

Lipton, M. and Rosenblum, S. A. (1991) A new system of corporate governance: The quinquennial election of directors. University of Chicago Law Review 58, 187-253.

Liu, G. and Garino, G. (2001) China's two decades of economic reform. Economics of Planning 34, $1-4$.

Liu, G. (2005) Comparative corporate governance: The experience between China and the UK. Corporate Governance 13, 1-3.

Liu, J. P. (2004) The corporate governance of fund management companies should be greatly improved. Securities Daily, $8^{\text {th }}$ December. 
Lloyd, W. P., Hand, J. H., and Modani, N. K. (1987) The effect of environmental dynamism on the ownership and performance relationship. Strategic Management Journal 19, 169-179.

Loderer, C. and Martin, K. (1997) Executive stock ownership and performance: Tracking faint traces. Journal of Financial Economics 45, 223-255.

Long, Y. (2001) Eight questions concerning independent directors. New Economic Herald 10.

Lowenstein, L. (1983) Pruning deadwood in hostile takeovers: A proposal for legislation. Columbia Law Review 83, 249-334.

Lu, T. (2003) Corporate governance in China. Working Paper, Chinese Academy of Social Science.

MacAvoy, O., Cantor, S., and Peck, S. (1983) ALI proposal for increased control of the corporation by the board of directors: An economic analysis, in Statement of the Business Roundtable on the American Law Institute's Proposed 'Principles of Corporate Governance and Structure: Restatement and Recommendation." Business Roundtable: New York.

MacNeil, I. (2002) Adaptation and convergence in corporate governance: The case of Chinese listed companies. Journal of Corporate Law Studies 2.

Manne, H. G. (1965) Mergers and the market for corporate control. Journal of Political Economy $73,110-120$.

Mar, P: and Young, M. N. (2001) Corporate governance in transition economy: A case study of two Chinese airlines. Journal of World Business 36, 280-302.

March, J. G. and Simon, H. A. (1958) Organisations. Wiley: New York.

Marris, R. (1964) The Economic Theory of Managerial Capitalism. Free Press of Glencoe: Glencoe, IL.

Maug, E. (1998) Large shareholder as monitors: Is there a trade-off between liquidity and control? Journal of Finance 53, 65-98.

McCarthy, D. and Puffer, S. (2003) Corporate governance in Russia: A framework for analysis. Journal of World Business 38, 397-415.

McConnell, J. J. and Servaes, H. (1990) Additional evidence on equity ownership and corporate value. Journal of Financial Economics 27, 595-612.

McConnell, J. J. and Servaes, H. (1995) Equity ownership and the two faces of debt. Journal of Financial Economics 39, 131-157.

McGregor, D. (1960) The Human Side of the Enterprise. McGraw-Hill: New York. 
McGregor, R. (2001) The little red book of business in China. Financial Times 8, July.

McMullen, D. A. (1996) Audit committee performance: An investigation of the consequences associated with audit committees. Auditing: A Journal of Practices and Theory 15, 87-103.

Mehran, H. (1995) Executive compensation structure, ownership, and firm performance. Journal of Financial Economics 38, 163-184.

Milgrom, P. and Roberts, J. (1992) Economics, Management and Organisation. Prentice Hall: Englewood Cliffs, NJ.

Miner, J. B. (1980) Theories of Organisational Behaviour. Dryden Press: Hinsdale, IL.

Mintzberg, H. (1983) Power in and around Organisations. Prentice Hall: Englewood, Cliff, NJ.

Mizruchi, M. S. (1983) Who controls whom? An examination of the relation between management and board of directors in large American corporations. Academy of Management Review 8, 426-435.

Moerland, P. W. (1995) Alternative disciplinary mechanisms in different corporate governance. Journal of Economic Behaviour and Organisation 26, 17-34.

Monks, R. A. (1997) Corporate governance and pension plans, in M. S. Gordon, O. S. Mitchell and M. M. Twinney (eds.) Positioning Pensions for the Twenty-First Century. The University of Philadelphia: Philadelphia, PA.

Monks, R. A. and Minow, N. (1995) Corporate Governance. Blackwell: Cambridge, MA.

Morck, R. and Nakamura, M. (1999) Banks and corporate control in Japan. Journal of Finance 54, 319-339.

Morck, R., Shleifer, A., and Vishny, R. (1988) Management ownership and market valuation: An empirical analysis. Journal of Financial Economics 20, 293-315.

Morck, R., Shleifer, A., and Vishny, R. (1989) Alternative mechanisms for corporate control. American Economic Review 79, 842-852.

Morgan, D. L. (1998) Practical strategies for combining qualitative and quantitative methods: Application to health research. Qualitative Health Research 8, 362-276.

Moyer, R. C., Rao, R., and Sisneros, P. M. (1992) Substitute for voting rights: Evidence from dual class recapitalisations. Financial Management 21, 35-47.

Mueller, D. and Sirower, M. (1998) The causes of mergers: Tests based on the gains to acquiring firms' shareholders and the size of premia. Mimeo.

Murali, R. and Welch, J. B. (1989) Agents, owners, control and performance. Journal of Business Finance and Accounting, Summer, 385-398. 
Murphy, A. and Topyan, K. (2005) Corporate governance: A critical survey of key concepts, issues, and recent reforms in the US. Employee Responsibilities and Rights Journal 17, 75-89.

Murphy, K. and Van Nuys, K. (1994) State pension fund shareholder activism. Working Paper, Harvard Business School.

Myners, P. (1995) Developing a Winning Partnership. DTI: London.

Neter, J., Wasserman, W., and Kutner, M. (1985) Applied Linear Statistical Methods $\left(2^{\text {nd }}\right.$ edn.) Irwin: Homewood, IL.

Nilakant, V. and Rao, H. (1994) Agency theory and uncertainty in organisations: An evaluation. Organisation Studies 15, 649-672.

Noe, T. (2002) Institutional activism and financial market structure. Review of Financial Studies $15,289-319$.

Noorderhaven, N. G. (1992) The problem of contract enforcement in economic organisation theory. Organisation Studies 13, 229-243.

Normanton, E. L. (1966) The Accountability and Audit of Governments. Manchester University Press: Manchester.

North, D. C. (1990) Institutions, Institutional Change and Economic Performance. Cambridge University Press: Cambridge.

O'Barr, W. M. and Conley, J. M. (1992) Fortune and Folly: The Wealth and Power of Institutional Investing. Homewood, IL: Business One Irwin.

O'Connor, M. A. (1999) Union pension power and the shareholder revolution. Paper presented at the 1999 SASE (Society for Advancement of Socio-Economics) Conference, Madison, WI.

OECD (2002) China in the world economy: The domestic policy challenge. OECD: Paris.

Opler, T. and Sokobin, J. (1997) Does coordinated institutional activism work? An analysis of the activities of the council of institutional investors. Working Paper, Ohio State University.

Opper, S., Wong, M. L. S., and Hu, R. (2002) Party power, market and private power: CCP persistence I China's listed companies. Research in Social Stratification and Mobility 19, $103-136$.

Orsbum, J. D., Linda, M., Muselwhite, E., and Zenger, J. H. (1990) Self-Directed Work Teams: The new American Challenge. Irwin: Homewood.

Ou, M. G. (2001) A comparative study about corporate governance of investment funds. Securities Market Journal, No. 5. 
Ouchi, W. G. (1978) The transmission of control through organisational hierarchy. Academy of Management Journal 21, 248-263.

Ouchi, W. G. (1980) Market, bureaucracies, and clans. Administrative Science Quarterly $29,129-141$.

Ouchi, W. G. and Maguire, M. A. (1975) Organisational control: Two functions. Administrative Science Quarterly 20, 559-569.

Patton, M. Q. (2002) Qualitative Research and Evaluation Methods. (3 ${ }^{\text {rd }}$ edn.) Sage Publications: London.

Pedersen, T. and Thomsen, S. (1999) Economic and systemic explanations of ownership concentration among Europe's largest companies. International Journal of the Economics of Business 6, 367-381.

Pellet, J. (1998) Teachers expands its curriculum. Chief Executive 139, 44-49.

Peng, M. W. (2000) Business Strategies in Transition Economies. Sage: Thousand Oaks.

Peng, M. W. (2003) Institutional transitions and strategic choices. Academy of Management Review 28, 275-296.

Peng, M. W. (2004) Outside directors and firm performance during institutional transitions. Strategic Management Journal 25, 453-471.

Peng M. W., Buch, T., and Filatotchev, I. (2003) Do outside directors and new managers help improve firm performance? An exploratory study in Russian privatisation. Journal of World Business 38, 348-360.

Peng M. W. and Heath, P. (1996) The growth of the firm in planned economies in transition: Institutions, organisations, and strategic choice. Academy of Management Review 21, 492-528.

People's Daily Online (2005a) Reshuffle of securities companies gathers pace. $24^{\text {th }}$ January. People's Daily Online (2005b) Reform of split share structure in Chinese stock markets in three phases. $16^{\text {th }}$ May.

Perfect, S. B. and Wiles, K. W. (1994) Alternative constructions of Tobin's q: An empirical comparison. Journal of Empirical Finance 1, 313-341.

Perkins, D. (1994) Completing China's move to market. Journal of Economic Perspectives $8,23-46$.

Perrow, C. (1993) Complex Organisations. McGraw-Hill: New York.

Pfeffer, J. (1981) Power in Organisations. Ballinger Publishing Co: Cambridge, MA.

Pincus, K., Rusbarsky, M., and Wong, J. (1989) Voluntary formation of audit committees among NASDAQ firms. Journal of Accounting and Public Policy 8, 239-265. 
Pinkowitz, L. and Williamson, R. (2001) Bank power and cash holdings: Evidence from Japan. The Review of Financial Studies 14, 1059-1082.

Pistor, K. and Xu, C. G. (2004) Governing stock market in transition economies: Lessons from China. Working Paper, Columbia Law School.

Poitevin, M. (1990) Strategic financial signalling. Internal Journal of Industrial Organisation 8, 499-518.

Porter, M. A. (1980) Competitive Strategy. Free Press: New York.

Pound, J. (1988) Proxy contents and the efficiency of shareholder oversight. Journal of Financial Economics 20, 237-265.

Pound, J. (1992) Raiders, targets, and politics: The history and future of American corporate control. Journal of Applied Corporate Finance 5, 6-18.

Pozen, R. C. (1994) Institutional investors: The reluctant activists. Harvard Business Review 72, 140-149.

Pratt, J. W. and Zeckhauser, R. J. (1985) Principals and agents: An overview, in J. W. Pratt and R. J. Zeckhauser (eds.) Principals and Agents: The Structure of Business. Harvard Business School: Boston.

Prevost, A. K. and Rao, R. P. (2000) Of what value are shareholder proposals sponsored by public pension funds? The Journal of Business 73, 177-204.

Procter, A. (1998) Accountability and transparency - the importance of reliable financial reporting and disclosure regimes: A regional perspective. Paper presented at the Corporate Governance in APEC: Rebuilding Asian Growth.

Qi, D., Wu, W., and Zhang, H. (2000) Shareholding structure and corporate performance of partially privatised firms: Evidence from listed Chinese companies. Pacific-Basin Finance Journal 8, 587-610.

Qian, Y. (1995) Reforming Corporate Governance and Finance in China, in M. Aoki and H. Kim (eds.) Corporate Governance in Transition Economies: Insider Control and the Role of Banks. The World Bank.

Qian, Y. Y. (1996) Enterprise reform in China: Agency problems and political control. Economics of Transition 4, 427-447.

Qian, Y. (2002) How reform worked in China. Working Paper, Berkeley University of California.

Qiang, Q. (2003) Corporate governance and state-owned shares in China listed companies. Journal of Asian Economics 14, 771-783.

Radcliffe, R. C. (1990) Investments. Scott Foresman: Glenview, IL. 
Rao, H. and Sivakumar, K. (1999) Institutional sources of boundary-spanning structures: The establishment of investor relations departments in the Fortune 500 industrials. Organisation Science 10, 27-42.

Rasmusen, E. (1989) Games and Information. Blackwell: Cambridge, MA.

Ravenscraft, D. and Scherer, F. M. (1987) Mergers, Sell-offs and Economic Efficiency. Brooking Institution: Washington.

Ravid, S. A. and Sarig, O. H. (1991) Financial signalling by committing to cash outflows. Journal of Financial and Quantitative Analysis 26, 165-181.

Roe, M. (1990) Political and legal restrains on ownership and control of public companies. Journal of Financial Economics 27, 7-41.

Romano, R. (1993) Public pension fund activism in corporate governance reconsidered. Columbia Law Review 93, 795-853.

Romano, R. (1998) Pension funds and corporate governance. Working paper, Yale Law School.

Romano, R. (2001) Less and more: Making institutional investor activism a valuable mechanism of corporate governance. Yale Journal of Regulation 18, $174-251$.

Roosevelt, M. (2000) How green is your money? Time, 156, 79.

Rubach, M. J. and Sebora, T. C. (1998) Comparative corporate governance: Competitive implications of an emerging convergence. Journal of World Business 33, 167-184.

Ryan, P. J. (1988) Rule 14a-8, institutional shareholder proposals, and corporate democracy. Georgia Law Review 23, 377-418.

Ryan, L. V. and Schneider, M. (2002) The antecedents of institutional investor activism. Academy of Management Review 27, 554-573.

Ryan, L. V. and Schneider, M. (2003) Institutional investor power and heterogeneity. Business and Society 42, 398-429.

Sarkar, J. and Sarkar, S. (2000) Large shareholder activism in corporate governance in developing countries: Evidence from India. International Review of Finance 1, 161194.

Schein, E. (1970) An Organisational Psychology (2 ${ }^{\text {nd }}$ edn.) Prentice-Hall: Englewood Cliffs, NJ.

Schneider-Lenne, E. (1993) Corporate control in Germany. Oxford Review of Economic Policy 8, 11-23.

Schneider, M. (2000) When financial intermediaries are corporate owners: An agency model of institutional ownership. Journal of Management and Governance 4, 207-237. 
Schwab, S. J. and Thomas, R. S. (1998) Realigning corporate governance: Shareholder activism by labour unions. Michigan Law Review 96, 1018-1094.

Securities Daily (2003) The financial institutions are becoming stronger. $27^{\text {th }}$ October.

Securities Daily (2005) The history of investment funds in China. $4^{\text {th }}$ January.

Seddighi, H. R. and Nian, W. (2004) The Chinese stock exchange market: Operation and efficiency. Applied Financial Economics 14, 785-797.

Servaes, H. (1991) Tobin's $q$ and the gains from takeovers. Journal of Finance 66, 409419.

Sesil, J., Kroumova, M., Kruse, D., and Blasi, J. (2000) Broad-based employee stock options in the US: Company performance and characteristics. Working Paper, Rutgers University.

Shanghai Securities Journal (2004) Investment funds took on all top ten tradable shareholders in Top Energy Company. $20^{\text {th }}$ July.

Sharma, A. (1997) Professional as agent: Knowledge asymmetry in agency exchange. Academy of Management Review 22, 758-798.

Shenkar, O. and von Glinow, M. A. (1994) Paradoxes of organisational theory and research: Using the case of China to illustrate national contingency. Management Science 40, 5671.

Sherman, H., Beldona, S., and Joshi, M. P. (1998) Institutional investor heterogeneity: implications for strategic decisions. Corporate Governance 6, 166-173.

Shetty, Y. K. (1979) New look at corporate goals. California Management Review 22, $71-$ 79.

Shi, S. and Weisert, D. (2002) Corporate governance with Chinese characteristics. The China Business Review 29, $40-44$.

Shin, H. H. and Stulz, R. M. (1998) Are internal capital markets efficient? Quarterly Journal of Economics 113, 531-552.

Shirai, S. (2004) Testing the three roles of equity markets in developing countries: The case of China. World Development 32, 1467-1486.

Shleifer, A. and Vishny, R. W. (1986) Large shareholders and corporate control. Journal of Political Economy 94, 461-488.

Shleifer, A. and Vishny, R. W. (1988) Value maximisation and the acquisition process. Journal of Economic Perspectives 2, 7-20.

Shleifer, A. and Vishny, R. W. (1994) Politicians and firms. Quarterly Journal of Economics 109, 995-1025. 
Shleifer, A. and Vishny, R. W. (1997) A survey of corporate governance. Journal of Finance 52, 737-783.

Shome, D. and Singh, S. (1995) Firm value and external blockholdings. Financial Management 24, 3-14.

Short, H. (1994) Ownership, Control, financial structure and the performance of firms. Journal of Economic Surveys 8, 203-249.

Short, H. and Keasey, K. (1997) Institutional shareholders and corporate governance, in K. Keasey and M. Wright (eds.) Corporate Governance: Responsibilities, Risks and Remuneration. John Wiley \& Sons: New York.

Short, H. and Keasey, K. (1999) Managerial ownership and the performance of firms: Evidence from the UK. Journal of Corporate Finance 5, 79-101.

Simon, H. A. (1955) A behavioural model of rational choice. Quarterly Journal of Economics 69, 99-118.

Singh, M. and Davidson, W. N. (2003) Agency costs, ownership structure and corporate governance mechanisms. Journal of Banking and Finance 27, 793-816.

Smith, C. W. and Watts, R. (1992) The investment opportunity set and corporate financing, dividend and compensation Policies. Journal of Financial Economics 32, 263-292.

Smith, P. M. (1996) Shareholder activism by institutional investors: Evidence from CalPERS. Journal of Finance 51, 227-252.

Spira, L. F. (1999) Ceremonies of governance: Perspectives on the role of the audit committee. Journal of management and Governance 3, 231-260.

Stamp, E. and Moonitz, M. (1978) International Auditing Standards. Prentice-Hall International: London.

Steinfeld, E. S. (1998) Forging Reform in China: The Fate of State-owned Industry. Cambridge University Press: Cambridge.

Stiglitz, J. E. (1985) Credit markets and the control of capital. Journal of Money, Credit and Banking 17, 133-152.

Stiglitz, J. E. (1994) Whither Socialism. The MIT Press: Cambridge.

Stiglitz, J. E. (1997) The role of government in economic development, in M. Bruno and B.

Pleskovic (eds.) Annual World Bank Conference on Development Economics 1996. World Bank: Washington DC.

Strickland, D., Wiles, K. W., and Zenner, M. (1996) A requiem for the USA: Is small shareholder monitoring effective? Journal of Financial Economics 40, 319-338. 
Stoney, C. and Winstanley, D. (2001) Stakeholding: Confusion or utopia? Mapping the conceptual terrain. Journal of Management Studies 38, 603-626.

Sucher, P. and Zelenka, I. (1998) The development of the role of the audit in Czech Republic. European Accounting Review 7, 723-751.

Sun, Q. and Tong, W. H. S. (2003) China share issue privatisation: The extent of its success. Journal of Financial Economics 70, 183-222.

Sun, Q., Tong, W. H. S., and Tong, J. (2002) How does government ownership affect firm performance? Evidence from China's privatisation experience. Journal of Business Finance and Accounting 29, 1-27.

Sycip, W. (1998) The managerial challenge and response to 1997/1998 Asian Economic Crisis. Malaysian Management Review 33, 1-9.

Tam, O. K. (1999) The Development of Corporate Governance Development in China. Cheltenham: Edward Elgar.

Tam, O. K. (2002) Ethical issues in the evolution of corporate governance in China. Journal of Business Ethics 37, 303-320.

Tenev, S., Zhang, C., and Brevort, L. (2002) Corporate Governance and Enterprise Reform in China: Building the Institutions of Modern Markets. World Bank and the International Finance Corporation, Washington DC.

The China Securities Regulatory Commission (2004) Summary for China Securities Investment Funds Market 2003, in China Securities and Futures Statistical Yearbook, 142. Baijia Publishing House: Beijing, China.

The Financial Economists Roundtable (1998) Financial Economists Roundtable statement on institutional investors and corporate governance. The Financier 5, 24-27.

The Institutional Shareholders' Committee (ISC) (1991) The Role and Responsibilities of Institutional Shareholders in the UK. Institutional Shareholder' Committee: London.

The Securities Association of China (2004) The Development Report of China's Securities Industry in 2004. The Finance and Economic Publishing House: Beijing, China.

The Shanghai Stock Exchange (SHSE) (2000) The Corporate Governance of China's Listed Companies. Shanghai Stock Exchange: Shanghai, China.

The Shanghai Stock Exchange (SHSE) (2003) China Corporate Governance Report. Fudan University Press: Shanghai, China.

The Standing Senate Committee (1998) The governance practices of institutional investors. http://www.parl.gc.ca/36/1/parlbus/commbus/senate/com-e/ban-e/rep-e. 
Thompson, J. D. (1967) Organisations in Action. McGraw-Hill: New York.

TIAA-CREF (2002) TIAA-CREF 2001 annual report. New York: Teachers Insurance and Annuity Association-College Retirement Equities Fund. Accessed on $21^{\text {st }}$ October 2003 at http://www.tiaa-cref.org/pubs/html/AR/01/index.html.

Tian, G. L. (2000) State shareholding and value of China's firms. Working Paper, London Business School.

Tobin, J. (1969) A general equilibrium approach to monetary theory. Journal of Money, Credit, and Banking 7, 15-29.

Tobin, J. (1978) Monetary policies and the economy: The transmission mechanism. Southern Economic Journal 44, 421-431.

Treadway Roundtable (1989) Management Accounting (March), 22-26.

Trice, H. M. and Beyer, M. (1984) Studying organisational cultures through rites and ceremonials. Academy of Management Review 9, 653-659.

Tricker, B. (1994a) Editorial: German tow tier boards and bank share holdings: The case of Metallegesellschaft. Corporate Governance 2, 123-124.

Tricker, R. I. (1994b) International Corporate Governance. Simon and Schuster: Singapore.

Useem, M. (1993) Executive Defense: Shareholder Power and Corporate Reorganisation. Harvard University Press: Cambridge, MA.

Useem, M. (1996) Investor Capitalism-How Money Managers Are Changing the Face of Corporate America. Basic Books: New York.

Useem, M., Bowman, E. H., Myatt, J., and Irvine, C. W. (1993) U.S. institutional investors look at corporate governance in the 1990s. European Management Journal 11, 175189.

Vafeas, N. (1999) The nature of board nominating committee and their role in corporate governance. Journal of Business Finance and Accounting 26, 199-225.

Vafeas, N. and Theodorou, E. (1998) The relationship between board structure and firm performance in the UK. British Accounting Review 30, 383-407.

Van Nuys, K. (1993) Corporate governance through the proxy process: evidence from 1989 Honeywell proxy solicitation. Journal of Financial Economics 34, 101-132.

Varian, H. (1990) Monitoring agents with other agents. Journal of Institutional and Theoretical Economics 146, 153-174. 
Verstegen, R. L. and Marguerite, S. (2002) The antecedents of institutional investor activism. Academy of Management Review 27, 554-573.

Wagster, J. and Prevost, A. (1996) Wealth effects of the CalPERS hit list to SEC changes in the proxy rules. Working Paper, Wayne State University.

Wahal, S. (1996) Pension fund activism and firm performance. Journal of Financial and Quantitative Analysis 31, 1-23.

Wall Street Journal (1993) CalPERS goes over CEO's heads in it its quest for higher returns. $22^{\text {nd }}$ January, $\mathrm{C} 1$.

Walsh, J. P. and Seward, J. K. (1990) On the efficiency of internal and external corporate control mechanisms. Academy of Management Review 15, 421-458.

Walter, C. E. and Howie, F. J. T. (2003) Privatising China: The Stock Markets and Their Role in Corporate Reform. John Wiley \& Sons (Asia): Singapore.

Wang, J. W. (2003) Governance role of different types of state-share holders: Evidence form China's listed companies. Unpublished $\mathrm{PhD}$ thesis, Hong Kong University of Science and Technology.

Wang, X. (2003) State-owned enterprise reform and corporate governance of China. Working Paper, the Fudan University.

Wang, X., Xu, L., and Zhu, T. (2004a) State-owned enterprises going public: The case of China. Economies of Transition 12, 467-487.

Wang, Y., Xu, D., Wang, Z., and Zhai, F. (2004b) Options and impact of China's pension reform: A computable general equilibrium analysis. Journal of Comparative Economics $32,105-127$.

Washington Post (1992) Westinghouse's outside directors to gain power. $4^{\text {th }}$ December, B3. Webb, E. J., Campbell, D. T., Schwartz, R. D., and Sechrest, L. (1966) Unobtrusive Measures: Nonreactive Measures in the Social Science. Rand McNally: Chicago.

Wei, Y. (2003) An overview of corporate governance in China. Syracuse Journal of International Law and Commence 30, 23-48.

Wei, Z. B. and Varela, O. (2003) State equity ownership and firm market performance:

Evidence from China's newly privatised firms. Global Finance Journal 14, 65-82.

Wei, Z., Xie, F., and Zhang, S. (2005) Ownership structure and firm value in China's privatised firms: 1991-2001. Journal of Financial and Quantitative Analysis 40, 87108. 
Weick, K. E. (1979) The Social Psychology of Organising. Addison-Wesley: Reading, Mass.

Weinstein, D. and Yafeh, Y. (1998) On the costs of a bank-centered financial system: Evidence from the changing main bank relations in Japan. Journal of Finance 53, 635672.

Weir, C., Laing, D., and McKnight, P. J. (2002) Internal and external governance mechanisms: Their impact on the performance of large UK public companies. Journal of Business and Accounting 29, 579-611.

Weisbach, M. S. (1988) Outside directors and CEO turnover. Journal of Financial Economics 20, 431-460.

Westphal, J. D. and Zajac, E. J. (1995) Who shall govern? CEO/board power, demographic similarity, and new director selection. Administrative Science Quarterly 40, 60-83.

Wharton Jr, C. R. (1995) Boards and investors today. Corporate Board 16, $1-6$.

White, H. (1980) Heteroskedasticity-consistent covariance matrix estimator and a direct test for heteroskedasticity. Econometrica $48,817-838$.

Wild, J. J. (1994a) Managerial accountability to shareholders: Audit committees and the explanatory power of earnings for returns. British Accounting Review 26, 353-374.

Wild, K. L. (1994b) Managerial incentives and the valuation of international joint venture formation. Unpublished $\mathrm{PhD}$ thesis, University of Manchester.

Williamson, O. E. (1964) The Economics of Discretionary Behaviour: Managerial Objectives in a Theory of the Firm. Prentice-Hall: Englewood Cliffs, NJ.

Williamson, O. E. (1985) The Economic Institutions of Capitalism. Free Press: New York.

Wilson, O. (1968) On the theory of syndicates. Econometrica 36, 119-132.

Wiwattanakantang, Y. (1999) An empirical study on the determinants of the capital structure of Thai firms. Pacific Basin Finance Journal 7, 371-403.

Wiwattanakantang, Y. (2001) Controlling shareholders and corporate value: Evidence from Thailand. Pacific-Basin Finance Journal 9, 323-362.

Wohlstetter, C. (1993) Pension fund socialism: Can bureaucrats run the blue chips? Harvard Business Review 71, 78.

Woidtke, T. (1996) Pension fund ownership and valuation effects. Working Paper, Texas A and $M$ University.

Woidtke, T. (2002) Agents watching agents?: Evidence from pension fund ownership and firm value. Journal of Financial Economics 63, 99-131. 
Wolfenzon, D. (1999) A theory of pyramidal structures. Working Paper, Harvard Business School.

Wong, S. (1985) The Chinese family firm: A model. British Journal of Sociology 36, 5872.

Wong, S. M., Opper, S., and Hu, R. (2004) Shareholding structure, depoliticisation and firm performance. Economies of Transition 12, 29-66.

Wood, R. and Bandura, A. (1989) Social cognitive theory of organisaitional management. Academy of Management Review 14, 361-384.

Woods, J. E. (1996) Corporate governance: An international comparison. Benefits and Compensation International 25, 2-9.

World Bank (1997) China 2020: Development Challenges in the New Century. Washington, D.C.

World Bank (1999) China: Weathering the Storm and Learning the Lessons. Country Study, Washington, DC.

World Bank (2002) Transition: The first ten years. Analysis and lessons from Eastern Europe and the former Soviet Union. Washington, DC.

Wright, M., Filatotchev, I., Hoskisson, R. E., and Peng, M. W. (2005) Strategy research in emerging economies: Challenging the conventional wisdom. Journal of Management Studies 42, 1-33.

Xia, Bin (2001) Report on China's privately placed funds.

Xiao, J. Z., Dahya, J., and Lin, Z. (2004a) A grounded theory exposition of the role of the supervisory board in China. British Journal of Management 15, 39-55.

Xiao, J. Z., Yang, H., and Chow, C. (2004b) The determinants and characteristics of voluntary Internet-based disclosures by listed companies. Journal of Accounting and Public Policy 23, 191-225.

Xiao, J. Z., Zhang, Y., and Xie, Z. (2000) The making of independent auditing standards in China. Accounting Horizons 14, 69-89.

Xu, L., Zhu, T., and Lin, Y. (2005) Politician control, agency problems and ownership reform: Evidence from China. Economics of Transition 13, 1-24.

$\mathrm{Xu}, \mathrm{X}$. and Wang, Y. (1997) Ownership structure, corporate governance, and firm performance: the case of publicly listed Chinese stock companies. World Bank Policy Research Working Paper No. 1794. World Bank: Washington DC.

$\mathrm{Xu}, \mathrm{X}$. and Wang, Y. (1999) Ownership structure and corporate governance in Chinese stock companies. China Economic Review 10, 75-98. 
Yafeh, Y. (2000) Corporate governance in Japan: Past performance and future prospect. Oxford Review of Economic Policy 16, 74-84.

Yamazawa, I. (1998) The Asia Economic Crisis and Japan. The Developing Economies 6, $332-351$.

Yeh, Y., Lee, T., and Ko, C. (2002) Corporate Governance and Rating System.

Yermack, D. (1996) Higher market valuation of companies with a small board of directors. Journal of Financial Economics 40, 185-212.

Yermack, D. (1997) Good timing: CEO stock option awards and company news announcements. Journal of Finance 52, 449-476.

Yin, R. K. (1981) The case study crisis: Some answers. Administrative Science Quarterly $26,58-65$.

Yin, R. K. (1993) A Review of Case Study Research: Design and Methods. Sage: London.

Yin, R. K. (2003) Case Study Research: Design and Methods ( $3^{\text {rd }}$ edn.) Sage: California.

Yoshikawa, T. (2001) Alternative corporate governance systems in Japanese firms: Implications for a shift to stockholder-centered corporate governance. Asia Pacific Journal of Management 18, 183-205.

Young, M., Peng, M., Ahlstrom, D., and Bruton, G. (2002) Governing the corporation in emerging economies: A principal-principal perspective. Best Papers Proceedings of the Academy of Management: Denver, Co.

Yuan, L. and Ruan, L. (2003) The problems of China's investment funds and the countermeasures. Securities Daily, $19^{\text {th }}$ July.

Zajac, E. J. and Westphal, J. D. (1996) Director reputation, CEO board power, and the dynamics of board interlocks. Administrative Science Quarterly 41, 507-529.

Zeckhauser, R. I. and Pound, J. (1990) Are large shareholders effective monitors? An investigation of share ownership and corporate performance, in R. G. Hubbard (eds.) Asymmetric Information, Corporate Finance and Investment. University of Chicago Press: Chicago.

Zhang, W. (2000) China's SOEs reform: A corporate governance perspective. Working paper, Peking University, China.

Zhang, X. (2001) 200-odd listed companies in China Establish System of Independent Directors. Guangming Daily, $20^{\text {th }}$ July.

Zhang, Y. (2002) Institutional investors and corporate governance. Unpublished $\mathrm{PhD}$ thesis, People's University of China. 
Zhou, M. and Wang, X. (2000) Agency cost and the crisis of China's SOE. China Economic Review 11, 297-317.

Zhou, X. C. (2004) Improving corporate governance and developing capital market. Speech at the Euromoney "China Forum: Capital Market and Corporate Governance." Beijing, $1^{\text {st }}$ December 2004.

Zhu, S., Li, F., and Jiang, W. (2002) The Funds' capital Market: Current Situation, Problem and Prospect. The Economic Science Publishing House: Beijing, China.

Zhuang, J. (1999) Corporate Governance in Asia: Some Conceptual Issues. Asian Development Bank: Manila.

Zingales, L. (1994) The value of the voting right: A study of the Milan Stock Exchange experience. Review of Financial Studies 7, 125-148.

Zou, H., Adams, M. B., and Buckle. M. J. (2003) Corporate risks and property insurance: Evidence from the People's Republic of China. Journal of Risk and Insurance 70, 289314.

Zou, H. and Adams, M. (2004) Corporate growth options, ownership and equity risks in the People's Republic of China. Working Paper, Lingnan University and University of Wales Swansea. 